\title{
8th Edition of The Archaeology, Bioarchaeology, Ethnography, Ethnohistory, and History of the Caddo Indian Peoples of Arkansas, Louisiana, Oklahoma, and Texas
}

Timothy K. Perttula

Heritage Research Center, Stephen F. Austin State University

Follow this and additional works at: https://scholarworks.sfasu.edu/ita

Part of the American Material Culture Commons, Archaeological Anthropology Commons, Environmental Studies Commons, Other American Studies Commons, Other Arts and Humanities Commons, Other History of Art, Architecture, and Archaeology Commons, and the United States History Commons

Tell us how this article helped you.

This Article is brought to you for free and open access by the Center for Regional Heritage Research at SFA ScholarWorks. It has been accepted for inclusion in Index of Texas Archaeology: Open Access Gray Literature from the Lone Star State by an authorized editor of SFA ScholarWorks. For more information, please contact cdsscholarworks@sfasu.edu. 
8th Edition of The Archaeology, Bioarchaeology, Ethnography, Ethnohistory, and History of the Caddo Indian Peoples of Arkansas, Louisiana, Oklahoma, and

Texas

Creative Commons License

(c) (1) (9)

This work is licensed under a Creative Commons Attribution-NonCommercial 4.0 International License 


\title{
$8^{\text {th }}$ Edition of The Archaeology, Bioarchaeology, Ethnography, Ethnohistory, and History of the Caddo Indian Peoples of Arkansas, Louisiana, Oklahoma, and Texas
}

\author{
Compiled by Timothy K. Perttula
}

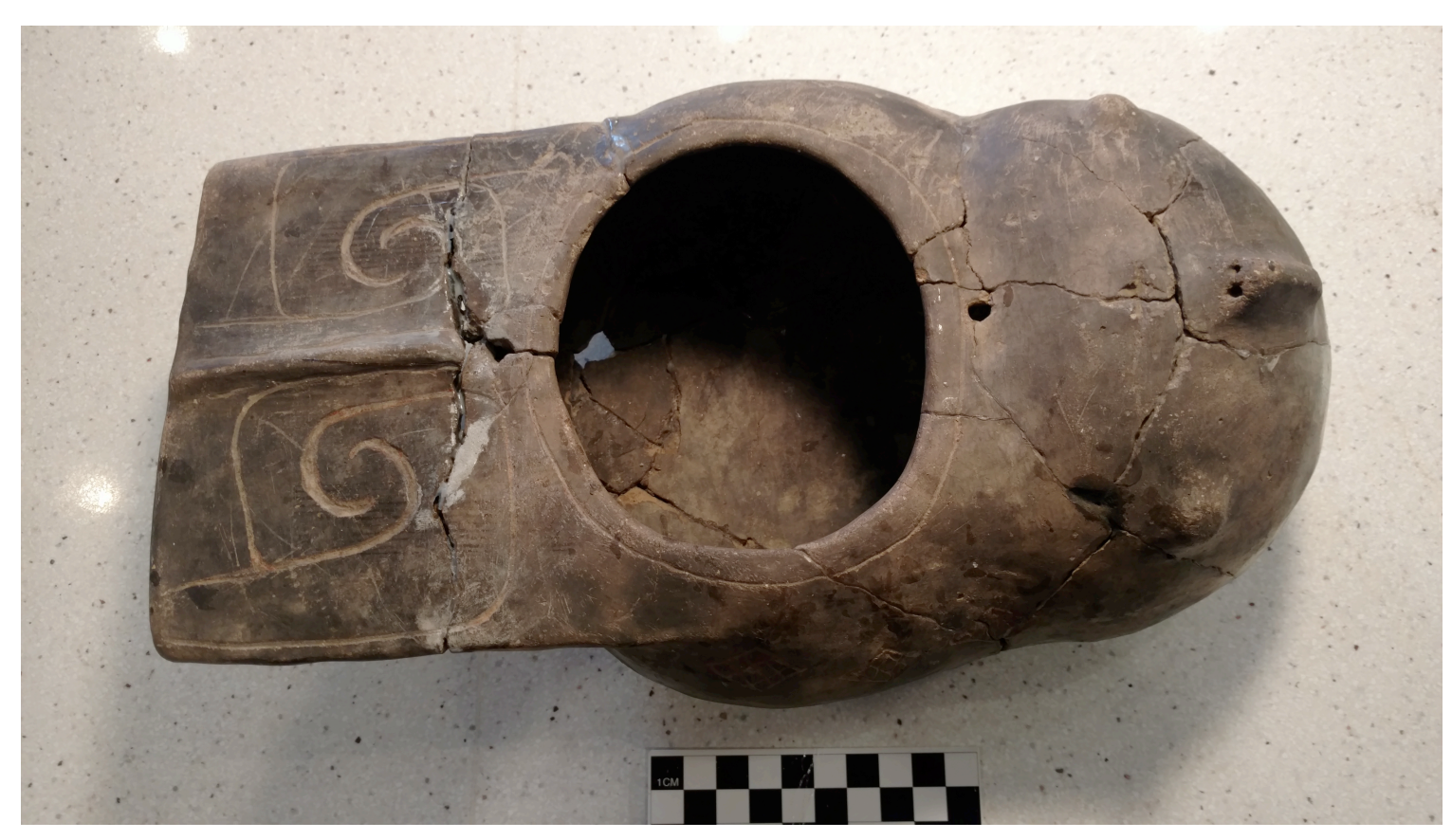

January 2018

Special Publication No. 51

Friends of Northeast Texas Archaeology, Austin and Pittsburg 


\section{Editor, Timothy K. Perttula 10101 Woodhaven Dr. Austin, Texas 78753 tkp4747@,aol.com}

\section{Distribution, Bo Nelson, 344 CR 4154 \\ Pittsburg, Texas 75686 \\ RBoNelson@aol.com}

Cover art: Effigy Vessel from the Tuck Carpenter Site (41CP5)

Special Publication No. 51

Copyright 2018, Friends of Northeast Texas Archaeology

Pittsburg and Austin 


\section{TABLE OF CONTENTS}

Acknowledgments $\quad 4$

Introduction, by Timothy K. Perttula 5

I, Caddo Archaeology and Bioarchaeology $\quad 8$

II, Caddo Ethnohistory \& Ethnography 329

$\begin{array}{ll}\text { III, Caddo History } & 347\end{array}$ 


\section{ACKNOWLEDGMENTS}

I would like to thank Ann M. Early, Lois E. Albert, Jeffrey S. Girard, Robert L. Brooks, Scott W. Hammerstedt, Shawn Marceaux, Duncan McKinnon, Robert Z. Selden, Jr., Waldo Troell, Mary Beth Trubitt, and Mark Walters for their help with this as well as previous compilations of the Caddo bibliography; I especially want to thank Duncan for his editorial help with this edition. W. W. Crook, III, Chris Lintz, Juliana Barr, and John Samuelsen have also provided useful suggestions and bibliographic additions, along with Christopher Goodmaster. 


\section{INTRODUCTION}

\section{Timothy K. Perttula}

This Bibliography, the January 2018 edition, is the latest and most comprehensive version of published sources concerning the archaeology, bioarchaeology, ethnography, ethnography, and history of the Caddo Indian peoples of the Trans-Mississippi South. I have continued to update and reformat the bibliography through the Friends of Northeast Texas Archaeology, not for publication but as a resource to be shared. It is my hope that this most current and $8^{\text {th }}$ edition of the bibliography will continue to be a useful reference work for people conducting research on, and/or are interested in, Caddo native history and culture.

This latest and updated version of the bibliography contains over 5400 references whose subject matter in some manner is about the Caddo Indian peoples, an aboriginal people that lived in southwest Arkansas, northwest Louisiana, eastern Oklahoma, and eastern Texas (Figure 1) from as early as the Woodland period (ca. 500 B.C. to A.D. 800) to the present-day. References concerning older cultures that inhabited the area-Archaic and Paleoindian cultures - are not included in the bibliography. The traditional homelands of the Caddo Indian peoples, centering on the Red River in the Great Bend area, covered approximately $200,000 \mathrm{~km}^{2}$.

The bibliography is organized into three major sections: (1) Caddo Archaeology and Bioarchaeology; (2) Caddo Ethnohistory \& Ethnography; and (3) Caddo History.

I intend the Caddo bibliography to include references to all works that address Caddo research questions and topics and/or provide information that will be useful to people involved in Caddo research in this region, and it is current as I can make it as of January 2017. These include cultural resources management (CRM) reports of limited distribution, journal articles, books, and other published or formally completed documents, as well as important unpublished references. I have tried to select references that have substantive information on the archaeology and history of the Caddo or their Woodland period ancestors within the boundaries of the Caddo area. I will continue to regularly update this Bibliography, and am actively seeking contributions from others interested in Caddo archaeology, bioarchaeology, ethnography, and history. 


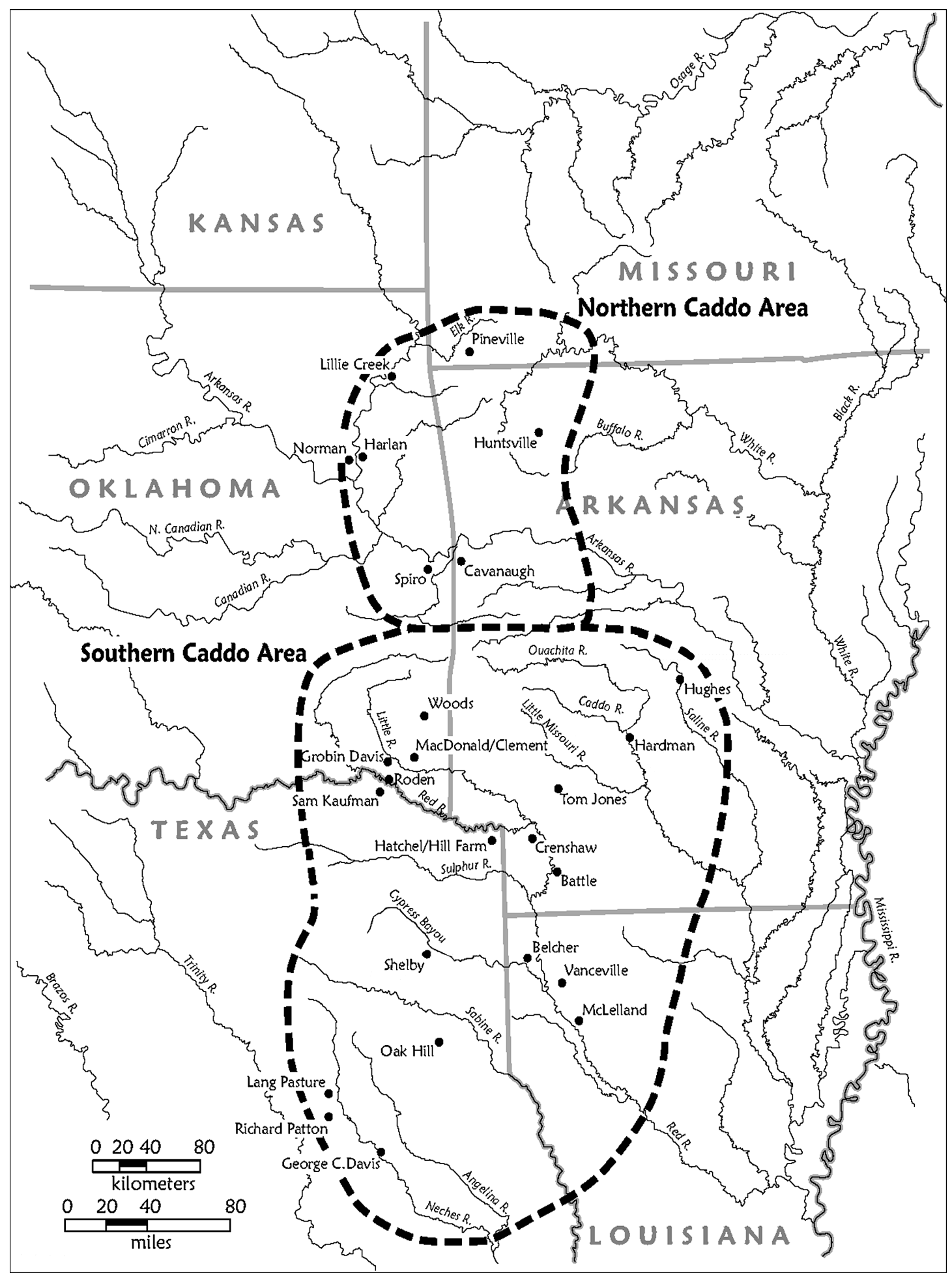

Figure 1. Map of the Caddo archaeological area, including both southern and northern areas. 
This bibliography will continue to be updated on a regular basis in a digital format, perhaps every six to 12 months. Thus, I would appreciate receiving submissions of new references, as well as mention of any older references that were inadvertently omitted from the present edition. These references can be submitted to:

Timothy K. Perttula

tkp4747@aol.com

10101 Woodhaven Dr.

Austin, Texas 78753-4346

$512-873-8131$ 


\section{CADDO ARCHAEOLOGY AND BIOARCHAEOLOGY}

Abbott, J. T.

2009 Geoarcheological Observations at Archeological Site 41TT108 in the ROW of FM 3417, Titus County, Texas. Texas Department of Transportation, Environmental Affairs Division, Archeological Studies Program, Austin.

2012 Geoarcheological Observations at Archeological Site 41SM42 in proposed new ROW of Smith CR 1141, Smith County, Texas. Texas Department of Transportation, Environmental Affairs Division, Archeological Studies Program, Austin.

Abbott, J. T., S. W. Troell, L. W. Ellis, and C. Wallace

2009 Report of Intensive Archeological Survey of Proposed Improvements to FM 2625 at Potter's Creek and Potter's Creek Relief, Harrison County, Texas. CSJ 0843-07-012. Texas Department of Transportation, Environmental Affairs Division, Archeological Studies Program, Austin.

Abernathie, J.

1991 Cultural Resources Survey of Proposed Timber Sale Compartments 92 and 94, Choctaw Ranger District, LeFlore County, Oklahoma. USFS Report 08-09-01-100a. Ouachita National Forest, Hot Springs.

1991 Cultural Resources Survey of Proposed Timber Sale Tracts, Compartment 45 Choctaw Ranger District, LeFlore County, Oklahoma. USFS Report 0809-01-78a. Ouachita National Forest, Hot Springs.

Acuna, L. I., J. McGilvray, S. Carpenter, A. Young, M. Garcia, and C. Nielsen 2011 Addendum Report II: Additional Cultural Resource Survey on the Keystone XL Pipeline Project: Gulf Coast Segment in Texas. Angelina, Cherokee, Fannin, Franklin, Hardin, Hopkins, Jefferson, Lamar, Nacogdoches, Orange, Polk, Rusk, Smith, Titus, Upshur, and Wood Counties, Texas. Cultural Resources Report No. 2008-392. SWCA Environmental Consultants, Austin.

Adair, M. J. and R. R. Drass

2011 Patterns of Plant Use in the Prehistoric Central and Southern Plains. In The Subsistence Economies of Indigenous North American Societies: A Handbook, edited by B. D. Smith, pp. 307-352. Smithsonian Institution Scholarly Press, Washington, D.C.

Adams, W. W.

1979 A Treatise on Selected Sites of Historical Significance Within, or in Close Proximity to Western Farmers Coal Fired Hugo Plant. Manuscript on file at the Oklahoma Archeological Survey, University of Oklahoma, Norman. 
Ahr, S. W.

1999 A Summary Report on Archeological Investigations at 41CE326: A Late Caddo Burial Site Inadvertently Discovered along US 69 south of Rusk, Cherokee County, Texas. Report on file. Archeological Studies Program, Environmental Affairs Division, Texas Department of Transportation, Austin.

2000 Archeological Survey for the South Tyler Enhancement Project and Testing of 41SM231, Smith County, Texas. Archeological Studies Program, Environmental Affairs Division, Texas Department of Transportation, Austin.

2001 Archeological Testing at the Prehistoric Site of 41SM231, Smith County, Texas. Occasional Papers of the Archeological Studies Program, Vol. 1, No. 2. Texas Department of Transportation.

2002 Archeological Testing at Prehistoric Site 41UR36, Upshur County, Texas. Occasional Papers Vol. 2, No. 1. Archeological Studies Program, Texas Department of Transportation.

Akridge, D. G.

2014 Stable Isotope Characteristics of the Skull and Mandible Remains from the Crenshaw Site, Miller County, Arkansas. The Arkansas Archeologist 52:37-63.

Albert, B. M.

2007 Climate, fire, and land-use history in the oak-pine forests of Northeast Texas during the past 3500 years. Castanea 72(2):81-90.

2011 Acidification and Pine Expansion in East Texas According to Pollen Evidence from Dual Cores in Alluvium. Castanea 76(2):164-177.

Albert, L. E.

1981 Ferndale Bog and Natural Lake: Five Thousand Years of Environmental Change in Southeastern Oklahoma. Studies in Oklahoma's Past No. 7. Oklahoma Archeological Survey, Norman.

1987 Archeological Testing in the Lee Creek Watershed, Sequoyah County, Oklahoma: 1986 Field Season. Oklahoma Archeological Survey, Norman.

1987 An Archeological Survey in the James Fork Watershed, LeFlore County, Oklahoma. Archeological Resource Survey Report No. 28. Oklahoma Archeological Survey, Norman. 
1987 The OAS Spring Dig and Field School at the Falling Cat Site (34Sq81). Oklahoma Anthropological Society Newsletter 35(5):3-6.

1989 National Register Testing of Archeological Sites in the Lee Creek Watershed Sequoyah County, Oklahoma. Oklahoma Archeological Survey, Norman.

1989 Continuing Studies in the Lee Creek Valley, Sequoyah County, Oklahoma. Oklahoma Anthropological Society Newsletter 37(2):4.

1991 Recent Excavations at the Tall Cane Site (34SQ294). Caddoan Archeology Newsletter 2(4):2-10.

1992 The Falling Cat Site (34SQ81), Lee Creek Watershed, Sequoyah County, Oklahoma. Bulletin of the Oklahoma Anthropological Society 39:1-55.

1992 Prehistory in Northeastern Oklahoma's Tall Grass Prairie: An Archeological Survey in the Coal Lands of Rogers, Mayes, and Craig Counties. Report Submitted to the State Historic Preservation Office. Manuscript on file at the Oklahoma Archeological Survey, University of Oklahoma, Norman.

2000 The Norman Site: Descriptions. Caddoan Archeology 11(1-2):23-59.

Albertson, E. S. and C. A. Buchner

2009 Phase I Archaeological Investigation for the Proposed Shady Lake Recreation Area Entrance Road, Ouachita National Forest, Mena Ranger District, Polk and Howard Counties, Arkansas. Panamerican Consultants, Inc., Memphis, Tennessee.

2012 Archeological Data Recovery at the Moore Homestead (3PL355) and Site 3PL576, Ouachita National Forest, Mena Ranger District, Polk County, Arkansas. Report No. 31056. Panamerican Consultants, Inc., Memphis, Tennessee.

2014 Phase II Testing at Sites 34MC769 and 34MC770, Ouachita National Forest, Tiak Ranger District, McCurtain County, Oklahoma. Report No. 31328. Panamerican Consultants, Inc., Memphis, Tennessee.

Albertson, P. E. and J. B. Dunbar

1993 Geomorphic Investigation of Shreveport to Daingerfield Navigation Project. Technical Report GL-93-31. United States Army Corps of Engineers, Waterways Experiment Station, Vicksburg.

Albertson, P. E., M. K. Corcoran, W. Autin, J. Kruger, and T. Foster 
1996 Geomorphic Investigation of the Great Bend Region, Red River. Technical Report GL-96. United States Army Corps of Engineers, Waterways Experiment Station, Vicksburg.

Allday, S. N. and K. J. Bastis

2008 Archeological Impact Evaluations and Surveys in the Atlanta, Dallas, Lufkin, Paris, and Tyler Districts of the Texas Department of Transportation: 2005-2007. Special Publication No. 20, Geo-Marine, Inc., Dallas, and Archeology Studies Programs Report No. 106, Environmental Affairs Division, Texas Department of Transportation, Austin.

Altschul, J. H.

1983 Brewer Bend Site (34Ms -130), Muskogee County, Oklahoma. Report prepared for the US Army Corps of Engineers, Tulsa District (Contract No. DACW56-83-M-0295). New World Research, Inc., Pollock, Louisiana.

Altschul, J. H. (editor)

1983 Bug Hill: Excavation of a Multicomponent Midden Mound in the Jackfork Valley, Southeast Oklahoma. Report of Investigations 81-1. New World Research Inc., Pollock, Louisiana.

Amick, C., E. Furman, T. K. Perttula, J. E. Bruseth, and B. C. Yates 1991 ALCOA \#1 (41AN87): A Frankston Phase Settlement along Mound Prairie Creek, Anderson County, Texas. Caddoan Archeology Newsletter 2(2):11-15.

Anderson, B.

1968 Lake Eufaula Yields Partial Burial with Two Flint Knives. Bulletin of the Oklahoma Anthropological Society 16:155-158.

Anderson, D. C. and J. A. Tiffany

1987 A Caddoan Trade Vessel from Northwestern Illinois. Plains Anthropologist 32(115):93-96.

Anderson, D. G. and S. D. Smith

2003 Archaeology, History, and Predictive Modeling, Research at Fort Polk, 1972-2002. University of Alabama Press, Tuscaloosa.

Anderson, D. G., J. W. Joseph, and M. B. Reed

1988 Technical Synthesis of Cultural Resource Investigations, Fort Polk, Louisiana. Garrow and Associates, Inc., Atlanta.

Anderson, K. M.

1972 Prehistoric Settlement of the Upper Neches River. Bulletin of the Texas Archeological Society 43:121-197. 
Anderson, K. M., K. Gilmore, O. F. McCormick III, and E. P. Morenon

1974 Archaeological Investigations at Lake Palestine, Texas. Contributions in Anthropology No. 11. Department of Anthropology, Southern Methodist University, Dallas.

Anonymous

1905 An Ancient Indian Cemetery. Records of the Past 4(12):372.

1905 Zane's Cave. Records of the Past 4:288.

1927 Find of Indian Relics on Henderson Farm near Park. The American Indian 2(2):3.

1934 Mound Builder in Oklahoma. El Palacio 34:100-101.

1959 Spiro Material at Smithsonian. Archaeology 12(1):66.

1962 Rare Art in Cave Viewed. Tulsa Tribune, May 18. Tulsa, OK.

2010 Artifact: Caddo Capital. Common Ground, Fall 2010, p. 42. National Park Service, Washington, D.C.

2011 Caddo Capital. Missouri Archaeological Society Quarterly 28(1):24.

2011 In Memoriam: Dee Ann Story, 1931-2010. SAA Archaeological Record 11(3):5.

Antle, H. R.

1933 The Mounds of Pontotoc. El Palacio 34:17-22.

1934 Excavation of a Caddoan Earth Lodge. The Chronicles of Oklahoma 12(4):444-446.

1935 Report of an Archaeological Site. The Chronicles of Oklahoma 13(2):191195.

1935 A Bluff Shelter in East Central Oklahoma. The Chronicles of Oklahoma 13(3):313-315.

1939 A Bluff Shelter in Pontotoc County. The Oklahoma Prehistorian 2(1): 6-11.

1940 Comments on an Oklahoma Pictograph. American Antiquity 6(2):166.

1942 A Southern Oklahoma Copper Ornament. American Antiquity 7(3):402403. 
Arkansas Archeological Survey

2003 Documentation of Sacred Objects, Objects of Cultural Patrimony, and Unassociated Funerary Objects at the Arkansas Archeological Survey: Vessels, Pipes, and Beads. CD-ROM. Project No. NPS-05-01-GP-292. Arkansas Archeological Survey, Fayetteville.

2016 Arkansas Novaculite: A Virtual Comparative Collection." website, available at

http://archeology.uark.edu/novaculite/index.html<http://arkarcheology.uark .edu/novaculite/index.html.http://arkarcheology.uark.edu/novaculite/index. $\underline{\mathrm{html}}$

Arnold, J. B., III

1973 George C. Davis Site Ceramic Analysis, Excavations of 1968-70. Master's thesis, Department of Anthropology, The University of Texas at Austin.

1975 Porosity and Refiring Tests on Ceramics from the George C. Davis Site, Texas. Bulletin of the Texas Archeological Society 46:231-241.

Assad, C. and D. R. Potter

1979 An Intensive Archaeological Survey of Enchanted Rock State Natural Area, Llano and Gillespie Counties, Texas. Archaeological Survey Report No. 84. Center for Archaeological Research, The University of Texas at San Antonio.

Athens, W. P., J. M. Wojtala, J. H. McClay, T. L. Paglione, W. A. Morgan, J. A. Cohen, and J. A. Green, Jr.

1991 A Cultural Resource Survey, Brown Bend Realignment and Slay Bend Revetment, Red River Waterways, Arkansas. R. Christopher Goodwin \& Associates, Inc., New Orleans.

Athens, W. E. P. Heinrich, J. M. Wojtala, J. A. Cohen, R. Draughton, Jr., S. B. Smith, A. R. Saltus, Jr., and W. Morgan

1992 Survey and Testing of Three Items on the Red River in Pools 4 and 5, Red River Waterway, Louisiana. R. Christopher Goodwin \& Associates, Inc., New Orleans.

Athens, W. P., B. Muller, P. V. Heinrich, S. Hinks, J. Cohen, and J. McClay 1992 Archeological Survey of the Proposed Royal Oak Enterprise Lignite Mine Site, Red River Parish, Louisiana. R. Christopher Goodwin \& Associates, Inc., New Orleans.

Atlee, W. A.

1953 Caddo Burial in Northeast Texas. Central Texas Archeologist 6:38-39. 
2004 Caddoan Ceramics and Associated Artifacts from Cement Hill Site No. 2 (41ML66), McLennan County, Texas. The Record 51:1-13. Dallas Archeological Society, Dallas.

Austin, D.

1984 Some Notes on an Interesting Pipe. Oklahoma Anthropological Society Newsletter 32(8):7-8.

Austin, S. P.

2004 Integrated Cultural Resources Management Plan for Lake O' the Pines, Texas. U.S. Army Corps of Engineers, Fort Worth District, Piney Woods Project, Jefferson.

2004 Integrated Cultural Resources Management Plan for Lake Wright Patman, Texas. U.S. Army Corps of Engineers, Fort Worth District, Piney Woods Project, Jefferson.

2006 Integrated Cultural Resources Management Plan for Lake Sam Rayburn, Texas. U.S. Army Corps of Engineers, Fort Worth District, Piney Woods Project, Jefferson.

Avery, G.

19951995 Annual Report for the Los Adaes Station Archaeology Program. Department of Social Sciences, Northwestern State University, Natchitoches.

1996 Eighteenth Century Spanish, French, and Caddoan Interactions as seen from Los Adaes. Journal of Northeast Texas Archaeology 7:27-68.

1997 More Friend Than Foe: Eighteenth Century Spanish, French, and Caddoan Interaction at Los Adaes: A Capital of Texas Located in Northwestern Louisiana. Louisiana Archaeology 22:163-193.

19961996 Annual Report for the Los Adaes Station Archaeology Program. Department of Social Sciences, Northwestern State University, Natchitoches.

1997 Los Adaes Station Archaeology Program, 1997 Annual Report. Department of Social Sciences, Northwestern State University of Louisiana, Natchitoches.

1998 Los Adaes Station Archaeology Program, 1998 Annual Report. Report on file at the Louisiana Division of Archaeology, Department of Culture, Recreation, and Tourism, Baton Rouge. 
1999 Los Adaes Station Archaeology Program, 1999 Annual Report. Report on file at the Louisiana Division of Archaeology, Department of Culture, Recreation, and Tourism, Baton Rouge.

2000 Los Adaes Station Archaeology Program, 2000 Annual Report. Report on file at the Louisiana Division of Archaeology, Department of Culture, Recreation, and Tourism, Baton Rouge.

2001 Los Adaes Station Archaeology Program, 2001 Annual Report. Report on file at the Louisiana Division of Archaeology, Department of Culture, Recreation, and Tourism, Baton Rouge.

2002 Los Adaes Station Archaeology Program, 2002 Annual Report. Report on file at the Louisiana Division of Archaeology, Department of Culture, Recreation, and Tourism, Baton Rouge.

2003 Los Adaes Station Archaeology Program, 2003 Annual Report. Report on file at the Louisiana Division of Archaeology, Department of Culture, Recreation, and Tourism, Baton Rouge.

2004 Los Adaes Station Archaeology Program, 2004 Annual Report. Report on file at the Louisiana Division of Archaeology, Department of Culture, Recreation, and Tourism, Baton Rouge.

2005 Los Adaes (16NA16) Glass Beads. Department of Social Sciences, Northwestern State University of Louisiana, Natchitoches.

2005 Los Adaes (16NA16) Lithics. Department of Social Sciences, Northwestern State University of Louisiana, Natchitoches.

2008 Seed Bead Patterns from Colonial Period Sites in Texas and Louisiana. Journal of Northeast Texas Archaeology 28:57-63.

2010 The Spanish in Northwest Louisiana, 1721-1773. In Archaeology of Louisiana, edited by M. A. Rees, pp. 223-234. Louisiana State University Press, Baton Rouge.

2011 Glass Trade Beads from the Los Adaes Site (16NA16). Louisiana Archaeology 32:106-135.

2011 Ground-Truthing Excavations at Los Adaes (16NA16), May 7, 2010. Stephen F. Austin State University Press, Nacogdoches.

2016 Mission Dolores Replication Project: Geophysical Survey and Shovel Testing, May 2008. Stephen F. Austin State University Press, Nacogdoches. 
2017 Seed Beads at Mission Dolores and Mission San Miguel: A Preliminary Study of Groupings by Color. Bulletin of the Texas Archeological Society 88:23-29.

Avery, G. E. and C. Phillips

2017 Report on the Combined 2016 Caddo Conference and East Texas Archeological Conference in Nacogdoches, Texas. Caddo Archeology Journal 27:105-113.

Avery, S. L.

1999 Draft Cultural Resources Survey for a Proposed Timber Harvest and Related Projects in Kingdoodle Ecosystem Management Unit Compartments 232/233/234, Cold Springs Ranger District, Ouachita National Forest, Scott County, Arkansas. Ouachita Cultural Resources Report No. 181. Ouachita National Forrest, Hot Springs.

2001 Proposed Mineral Extraction Pit (PIF). Ouachita National Forest, Hot Springs.

2003 Peeler Gap Forest Service Road 156 Reconstruction. Ouachita National Forest, Hot Springs.

Avery, S. L. and R. E. Coleman

1993 Cultural Resources Survey for a Proposed land Sale and land Exchange in Jessieville and Oden Ranger Districts, Ouachita National Forest, Garland and Montgomery Counties, Arkansas. Ouachita Cultural Resources Report No. 50. Ouachita National Forest, Hot Springs.

Avery, S. L., L. Rue, and G. Barber

2003 Cultural Resource Survey for a Proposed Timber Harvest and Related Projects in Stevens Branch Ecosystem. Ouachita Cultural Resources Report No. 221. Ouachita National Forest, Hot Springs.

2003 Cultural Resource Survey for a Proposed Timber Harvest and Related Projects in North Waldron Ridge Ecosystem Management Unit. Ouachita Cultural Resources Report No. 211. Ouachita National Forest, Hot Springs.

Baber, D.

1988 Cultural Resources Report 08-09-08-33 Documenting Survey of Road N55G Compartment 1955, Mena Ranger District, Ouachita National Forest. Ouachita National Forest, Hot Springs. 
1988 Cultural Resources Report 08-09-08-44 Documenting Survey of Road Compartment 1953, Mena Ranger District, Ouachita National Forest. Ouachita National Forest, Hot Springs.

1988 Cultural Resources Report 08-09-08-142 Documenting Timber Harvest in Compartment 981, Mena Ranger District, Ouachita National Forest. Ouachita National Forest, Hot Springs.

1989 Cultural Resources Report 08-09-08-44 Documenting Survey of Road N55G Compartment 1955, Mena Ranger District, Ouachita National Forest. Ouachita National Forest, Hot Springs.

Baerreis, D. A.

1939 Two New Cultures in Delaware County, Oklahoma. The Oklahoma Prehistorian 2(1):2-5.

1940 The Neosho Focus. Society for American Archaeology Notebook 1:108109.

1940 Delaware County Effigy. The Oklahoma Prehistorian 3(1):1.

1941 Recent Developments in Oklahoma Archaeology. Proceedings of the Oklahoma Academy of Science 21:125-126.

1943 A Typological Method in Archaeology and Its Application. Master's thesis, Department of Anthropology, University of Oklahoma, Norman.

1947 Spiro Focus Basketry. Information Series Circular No. 2. The Museum of the University of Oklahoma, Norman.

1953 Woodland Pottery of Northeastern Oklahoma. In Prehistoric Pottery of the Eastern United States. Museum of Anthropology, University of Michigan, Ann Arbor.

1954 The Huffaker Site, Delaware County, Oklahoma. Bulletin of the Oklahoma Anthropological Society 2:35-48.

1955 Further Materials from the Huffaker Site, Delaware County, Oklahoma. Bulletin of the Oklahoma Anthropological Society 3:53-68.

1957 The Southern Cult and the Spiro Ceremonial Complex. Bulletin of the Oklahoma Anthropological Society 5:23-28.

1959 A Report on a Bluff Shelter in Northeastern Oklahoma. Archives in Archeology No. 1. Society for American Archaeology. 
1960 Shell Tempered Pottery in Northeastern Oklahoma. Bulletin of the Oklahoma Anthropological Society 8:1-2.

1960 Archaic and Early Ceramic Complexes Ancestral, or Related to the Gibson Aspect. Bulletin of the Texas Archeological Society 31:95-96.

Baerreis, D. A. and J. E. Freeman

1959 A Report on a Bluff Shelter in Northeastern Oklahoma (DI-47). Archives of Archaeology No. 7. Society for American Archaeology.

1960 D1-47, a Bluff Shelter in Northeastern Oklahoma. Bulletin of the Oklahoma Anthropological Society 9:67-75.

Baerreis, D. A., J. E. Freeman, and J.V. Wright

1958 The Contracting Stem Projectile Point in Eastern Oklahoma. Bulletin of the Oklahoma Anthropological Society 6:61-82.

Baerreis, D. A., W. L. Wittry, and R. L. Hall

1956 The Burial Complex of the Smith Site, Delaware County, Oklahoma.

Bulletin of the Oklahoma Anthropological Society 4:1-12.

Baker, C. M.

1974 A Study of Aboriginal Novaculite Exploitation in the Ouachita Mountains of South-Central Arkansas. Master's thesis, Department of Anthropology, University of Arkansas, Fayetteville.

1982 A Brief Study of the Arkansas Novaculite Quarries. In Fancy Hill: Archeological Studies in the Southern Ouachita Mountains, edited by A. M. Early and W. F. Limp, pp. 307-334. Research Series No. 16. Arkansas Archeological Survey, Fayetteville.

Ball, H. F.

1986 Rock Art at Monk's Cave (41RK84), Rusk County, Texas. Bulletin of the Texas Archeological Society 55:153-169.

Banks, L.

1983 Prehistoric Engineering Along a Meandering River: A Hypothesis. In River Meandering. Proceedings of the Conference on Rivers, 1983, edited by C. M. Elliott, pp. 191-203. American Society of Civil Engineers, New York.

1990 From Mountain Peaks to Alligator Stomachs: A Review of Lithic Sources in the Trans-Mississippi South, the Southern Plains, and Adjacent Southwest. Memoir No. 4. Oklahoma Anthropological Society, Norman.

1996 Kiomatia Mounds. In The New Handbook of Texas, Vol. 3, edited by R. Tyler, p. 1120. Texas State Historical Association, Austin. 
Banks, L. D. and N. T. Banks

2002 Last Twentieth Century Archeological Investigations at the Arnold Roitsch Site (41RR16), Red River County, Texas. Larry D. Banks, Detroit, Texas.

Banks, L. D. and J. Winters

1975 The Bentsen-Clark Site, Red River County, Texas: A Preliminary Report. Special Publication No. 2. Texas Archeological Society, San Antonio.

Bareis, C. J.

1955 The Brackett Site, Ck-43, of Cherokee County, Oklahoma. Bulletin of the Oklahoma Anthropological Society 3:1-39.

1957 Comments on Prehistoric Corn Samples. Oklahoma Anthropological Society Newsletter 6(5):7-8.

1959 Ecology and Subsistence in Prehistoric Eastern Oklahoma. Oklahoma Anthropological Society Newsletter 8(3):8-9.

Bareis, C. J. and J. W. Porter

1965 Megascopic and Petrographic Analyses of a Foreign Pottery Vessel from the Cahokia Site. American Antiquity 31(1):95-101.

Barker, A. W., C. E. Skinner, M. S. Shackley, M. D. Glascock, and J. D. Rogers 2002 Mesoamerican Origin for an Obsidian Scraper from the Precolumbian Southeastern United States. American Antiquity 67(1):103-108.

Barkwill-Love, L.

2012 Petrographic Analysis of Leon Plain and Caddoan Ceramics. In Archeological Testing and Data Recovery at the Flatrock Road Site, 41KM69, Kimble County, Texas, by J. L. Thompson, R. P. Mauldin, S. A. Tomka, and E. Oksanen, pp. 345-394. Archeological Studies Program, Report No. 133. Texas Department of Transportation, Environmental Affairs Division, Austin.

Barnard, H. D.

1939 Early History of Research in Texas Archeology by the Department of Anthropology, and the History of the Anthropology Museum of the University of Texas. Master's thesis, Department of Anthropology, The University of Texas at Austin.

Barnes, J. E.

1992 Bioarchaeological Analysis of Human Skeletal Remains from Lake Eufaula. Report prepared for the U.S. Army Corps of Engineers, Tulsa District. 
Barnes, J. E. and R. L. Guendling

1995 From Shreveport to Monroe: An Archeological Survey of the Proposed Arkla, Inc. Line F Replacement. Project 892 Final Report. Arkansas Archeological Survey, Fayetteville.

Barnes, M. R., and T. K. Perttula

1999 Caddoan Ceremonial Sites of the Caddoan Cultural Area of Arkansas, Louisiana, Oklahoma, and Texas: Draft Caddo National Historic Landmark Nomination. Caddoan Archeology 10(1):5-29.

Barnhart, E., B. Dixon, S. Kotter, M. Nash, K. Reese-Taylor, E. Skokan, and R. Taylor

1997 Data Recovery Excavations at Site 41TT372 and 41TT550 in the Tankersley and Hayes Creek Watersheds, Monticello B-2 Surface Mine, Titus County, Texas. Document No. 940608. Espey Huston \& Associates, Inc., Austin.

Barr, T. P.

1963 Reservoir Survey Activity in Eastern Oklahoma. Oklahoma Anthropological Society Newsletter 11(8):6-7.

1965 Archaeological Survey of the Arkansas River Navigational Project, Muskogee and Wagoner Counties, Oklahoma. General Survey Report No.

5. Oklahoma River Basin Survey, University of Oklahoma Research Institute, Norman

1966 Three Archaeological Sites in the Pine Creek Reservoir, McCurtain County, Oklahoma. General Survey Report No. 7. Oklahoma River Basin Survey Project, University of Oklahoma Research Institute, Norman.

1966 An Archaeological Survey of the Chimney Rock and Little Saline Reservoirs, Mayes County, Oklahoma. General Survey Report No. 8. Oklahoma River Basin Survey Project, University of Oklahoma Research Institute, Norman.

1966 An Archaeological Survey of the Rock Creek Watershed, LeFlore and Latimer Counties, Oklahoma. Oklahoma River Basin Survey Project, University of Oklahoma Research Institute, Norman.

Bartlett, R. B. (compiler)

2002 Oklahoma Department of Transportation Cultural Resources Program Summary of Activities, Fiscal Year 2002. Oklahoma Department of Transportation, Cultural Resources Program, Norman, Oklahoma.

Baskin, B. J. 
1981 Lithic and Mineral Artifacts. In Archeological Investigations at the George C. Davis Site, Cherokee County, Texas: Summers of 1979 and 1980, edited by D. A. Story, pp. 239-320. Occasional Papers, Vol. 1. Texas Archeological Research Laboratory, The University of Texas at Austin.

Bass, W. M. and C. J. Loveland

1983 Biological Anthropology of the George Preston, Smith, and Sam Sites: Three Fourche Maline Sites. Bulletin of the Texas Archeological Society 53:83-100.

Bastian, T.

1968 An Archaeological Survey of the Frogville Watershed Project, Choctaw County, Oklahoma. General Survey Report No. 9. Oklahoma River Basin Survey Project, University of Oklahoma, Norman.

Baugh, S.

1982 Radiocarbon Dates from the McCutchan-McLaughlin Site, 34LT-11. Oklahoma Anthropological Society Newsletter 30(2):4-8.

Baugh, T. G.

1998 Regional Polities and Socioeconomic Exchange: Caddoan and Puebloan Interaction. In The Native History of the Caddo: Their Place in Southeastern Archeology and Ethnohistory, edited by T. K. Perttula and J. E. Bruseth, pp. 145-158. Studies in Archeology 30. Texas Archeological Research Laboratory, The University of Texas at Austin.

2014 Cultural Cycling among the Caddo and Wichita: A Study of Frontier Interaction as Viewed from the Lowrance Site (34MR10). Oklahoma Anthropological Society Bulletin LXI:1-54.

Baugh, T. G. and F. E. Swenson

1980 Comparative Trade Ceramics: Evidence for the Southern Plains Macroeconomy. Bulletin of the Oklahoma Anthropological Society 29:83102.

Baugh, T. G., L. B. Conyers, S. N. DeFreece, M. J. Guccione, D. B. Lee, T. K. Perttula, F. F. Schambach, S. A. Sundermeyer, and C. P. Walker

2004 A Research Design for the Bowie County Levee Realignment Project, Northeast Texas and Southwest Arkansas. Research Design Series, Report No. 1. LopezGarcia Group, Dallas.

Bauxar, J. J. (Finkelstein)

1950 The Norman Site WgNr: Wagoner County, Oklahoma. Manuscript on file at Sam Noble Oklahoma Museum of Natural History, Norman. 
1953 Evidence of a Subsurface Chamber Under the Brown Mound at Spiro. American Antiquity 19(2):169-170.

Beamer, H. and J. F. Schweikart

1990 A Phase I Archaeological Survey for the Oklahoma-Arkansas Pipeline Company Spread 1 Located in Pittsburg, Latimer, and LeFlore Counties, Oklahoma. Report Submitted to Oklahoma-Arkansas Pipeline Company. Archaeological Services Consultants, Inc., Columbus, Ohio.

Belew, J. and M. Tiemann

2010 Cultural Resources Investigation Report for Classic Hydrocarbon's Inc.'s First State Bank of Tenaha No. 1 Well Pad and Access Road and First State Bank of Tenaha No. 2 Well Pad and Access Road. Sphere 3 Environmental, Inc., Austin.

Bell, M.

1981 The Alex Justiss Site. A Caddoan Cemetery in Titus County, Texas. Publications in Archaeology No. 21. Highway Design Division, Texas Department of Highways and Public Transportation, Austin.

Bell, R. E.

1947 Trade Materials at Spiro Mound as Indicated by Artifacts. American Antiquity 12:181-184.

1947 Preliminary Report on Archaeological Activities Conducted by the Department of Anthropology in the Wister Reservoir Area in the Summer of 1947. Report on file at Oklahoma Archeological Survey, Norman.

1948 Recent Archeological Research in Oklahoma. Bulletin of the Texas Archeological and Paleontological Society 19:148-154.

1949 Archaeological Excavations at the Harlan Site, Fort Gibson Reservoir, Cherokee County, Oklahoma. Plains Anthropological Conference Newsletter 3(1):3-15.

1949 Recent Archaeological Research in Oklahoma. The Chronicles of Oklahoma 27(3):303-312.

1949 Archaeological Research in Oklahoma During 1947. Proceedings of the Fifth Plains Conference for Archeology, Notebook No. 1:6-7.

1950 Some References on Oklahoma Archeology. Archaeological Newsletter 1(3):1-5.

1951 Field Report on Work at Tenkiller Reservoir. Archaeological Newsletter 2(3):1-2. 
19521952 Archaeological Fieldwork. Oklahoma Anthropological Society Newsletter 1(3):1-3.

1952 Prehistoric Oklahoma: Or the Boomers Came Lately. The Oklahoma Quarterly 1(3):33-35.

1953 The Scott Site, LeFlore County, Oklahoma. American Antiquity 18(4):314331.

1953 Pottery Vessels from the Spiro Mound, C-1, LeFlore County, Oklahoma. Bulletin of the Oklahoma Anthropological Society 1:25-38.

1955 Radiocarbon Dates for Wood Specimens from the Spiro Mound. Oklahoma Anthropological Society Newsletter 4(1):2.

1955 References on Oklahoma Archaeology. Oklahoma Anthropological Society Newsletter 3(9):4-10.

1956 Stone Pipe Found in Muskogee County, Oklahoma. Oklahoma Anthropological Society Newsletter 5(5):5-6.

1956 Radiocarbon Dates from the Harlan Site, Cherokee County, Oklahoma. Oklahoma Anthropological Society Newsletter 5(3):6-7.

1956 Radiocarbon Dates from the Harlan Site, Cherokee County, Oklahoma. Oklahoma Anthropological Society Newsletter 5(6):2.

1957 Radiocarbon Date from the Spiro (Craig) Mound. Oklahoma Anthropological Society Newsletter 6(6):5-6.

1958 Notes and News - Oklahoma (Harlan Site). Oklahoma Anthropological Society Newsletter 7(3):1-2.

1958 Radiocarbon Dates from Oklahoma. Oklahoma Anthropological Society Newsletter 7(3):3-4.

1958 Bibliography of Oklahoma Archaeology. Bulletin of the Oklahoma Anthropological Society 6:89-91.

1959 Radiocarbon Dates from Oklahoma Sites. Oklahoma Anthropological Society Newsletter 8(4):2.

1961 Relationships Between the Caddoan Area and the Plains. Bulletin of the Texas Archeological Society 31:51-64. 
1961 Drama of the Spiro Mound. Oklahoma Anthropological Society Newsletter 9(9):3-6.

1961 Reviews of "A Report on a Bluff Shelter in Northeastern Oklahoma (DI-47)" by D. A. Baerreis and J. E. Freeman, and "An Archaeological Report on a Cave Deposit in Northeastern Oklahoma (DI-30)" by J. E. Freeman. American Antiquity 26(4):568-569.

1961 Radiocarbon Dates from Archaeological Sites in Oklahoma. Bulletin of the Oklahoma Anthropological Society 9:77-80.

1961 Some Recent Radiocarbon Dates for Oklahoma. Oklahoma Anthropological Society Newsletter 9(5):4.

1961 Discoveries in McCurtain County, Oklahoma. Oklahoma Anthropological Society Newsletter 9(9):3.

1962 Additional Radiocarbon Dates from Gibson Aspect Sites in Eastern Oklahoma. Oklahoma Anthropological Society Newsletter 10(6):1-2.

1963 Some New Radiocarbon Dates from Oklahoma. Oklahoma Anthropological Society Newsletter 11(9):3-4.

1965 Bibliography of Oklahoma Archaeology (Part I). Oklahoma Anthropological Society Newsletter 13(4):3-8.

1965 Bibliography of Oklahoma Archaeology (Part II). Oklahoma Anthropological Society Newsletter 13(5):5-14.

1966 Field Reports at 7th Caddo Conference (1963), Oklahoma: Harlan Site, Grand River Area. In Caddoan Field Reports 1962-1964 Field Seasons, edited by H. A. Davis, p. 12. University of Arkansas Museum, Fayetteville.

1966 Field Reports at 8th Caddo Conference (1965): Oklahoma, Harlan Site. In Caddoan Area Field Reports; 1962-1964 Seasons, edited by H. A. Davis, pp. 42-57. University of Arkansas Museum, Fayetteville.

1968 Dating the Prehistory of Oklahoma. Great Plains Journal 7(2):1-11.

1968 Archaeological Sites in Oklahoma. Oklahoma Anthropological Society Newsletter 16(7):8-9.

1969 Oklahoma Archaeology: An Annotated Bibliography. University of Oklahoma Press, Norman, Oklahoma. 
1972 The Harlan Site, Ck-6, A Prehistoric Mound Center in Cherokee County, Eastern Oklahoma. Memoir 2. Oklahoma Anthropological Society, Norman.

1973 Additional Notes on Chipped Double-Bitted Axes. Oklahoma Anthropological Society Newsletter 21(2):9.

1973 Chipped Double-Bitted Axes - Continued. Oklahoma Anthropological Society Newsletter 21(3):1-3.

1973 Chipped Double-Bitted Axes - Continued. Oklahoma Anthropological Society Newsletter 21(5):6-9.

1973 Some Comments Upon Chipped Double-Bitted Axes. Oklahoma Anthropological Society Newsletter 21(1):3-9.

1974 Mounds and Fieldwork near Muskogee, Oklahoma. Oklahoma Anthropological Society Newsletter 22(8):6-9.

1978 Oklahoma Archaeology: An Annotated Bibliography. University of Oklahoma Press, Norman.

1980 Oklahoma Indian Artifacts. Contributions from the Stovall Museum No. 4. Norman.

1980 Fourche Maline: An Archaeological Manifestation in Eastern Oklahoma. In "Caddoan and Poverty Point Archeology: Essays in Honor of Clarence $\mathrm{H}$. Webb," edited by J. L. Gibson. Louisiana Archaeology 6:83-125.

1981 A Stone Earspool from the Allcorn Site, McClain County, Oklahoma. Oklahoma Anthropological Society Newsletter 29(5):10.

1984 Arkansas Valley Caddoan: The Harlan Phase. In Prehistory of Oklahoma, edited by R. E. Bell, pp. 221-240. Academic Press, Orlando.

1987 The Development of Archaeology in Oklahoma. Bulletin of the Oklahoma Anthropological Society 36:1-14.

2006 My Early Days in the Southern Plains of Oklahoma. Plains Anthropologist 51(200):577-586.

Bell, R. E. (editor)

1984 Prehistory of Oklahoma. Academic Press, Orlando.

Bell, R. E. and D. A. Baerreis 
1951 A Survey of Oklahoma Archaeology: Bulletin of the Texas Archeological and Paleontological Society 22:7-100.

Bell, R. E. and C. Dale

1953 The Morris Site, Ck-39, Cherokee County, Oklahoma. Bulletin of the Texas Archeological Society 24:69-140.

Bell, R. E. and R. H. Fraser

1952 Archaeological Discoveries at the Morris Site, Cherokee County, Oklahoma. The Chronicles of Oklahoma 30(2):216-235.

Bell, R. E., G. S. Lacy, Jr., M. T. Joscher, and J. C. Allen

1969 The Robinson Solesbee Site, Hs-9: A Fulton Aspect Occupation, Robert S. Kerr Reservoir, Eastern Oklahoma. Archaeological Site Report No. 15. Oklahoma River Basin Survey Project, University of Oklahoma, Norman.

Bender, M.B., R.A. Bryson, and D.A. Baerreis

1965 University of Wisconsin Radiocarbon Dates I. Radiocarbon 7:399-407.

1967 University of Wisconsin Radiocarbon Dates III. Radiocarbon 9:530-544.

Benham, B. L., H. L. Miller, and J. V Sciscenti

1973 Archaeological Research in the Toledo Bend Reservoir. Archaeology

Research Program, Southern Methodist University, Dallas.

Benn, D. W. and N. H. Lopinot (editors)

1993 The Prehistoric Occupations at Cobb Cave in the Western Ozarks. The Missouri Archaeologist 54:55-78.

Benn, D. W. and J. H. Ray

1996 The Prospect Spring Site and the Problem of the Late Woodland/Mississippian Transition in the Western Ozarks. Midcontinental Journal of Archaeology 21(1):49-78.

Bennett, K. A.

1961 Artificial Cranial Deformation among the Caddo Indians. The Texas Journal of Science 13:377-390.

Bennett, W. J., Jr.

1980 Test Excavations at Mc-246. Museum of the Red River, Idabel.

1980 Test Excavations at the Crawford Site (Ch-119) and the Carnet Creek Site (Ch-121). Museum of the Red River, Idabel. 
1980 Archaeological and Cultural Resource Survey of Twenty Three Compartments in the Tiak Ranger District, McCurtain County, Oklahoma, Ouachita National Forest. Museum of the Red River, Idabel.

1981 Timber Roads Survey: Ouachita National Forest, Arkansas and Oklahoma. Archeological Assessments Report No. 7. Nashville, Arkansas.

1982 Cultural Resources Survey of DeQueen Lake Shoreline, Southwest Arkansas. Archaeological Assessments, Inc., Nashville, Arkansas.

1982 Archeological Investigations within the Bayou Bodcaw and Tributaries Project Area, Louisiana. Report No. 21. Archeological Assessments, Inc., Nashville, Arkansas.

1983 Predictive Model for the Location of Cultural Resources in the Ouachita National Forest, Arkansas and Oklahoma. Report No. 33. Archeological Assessments, Inc., Nashville, Arkansas.

1984 Survey and Synthesis of Available Cultural Resource Data, Coal Lands; Southeast Oklahoma: Bibliography. Archeological Assessments, Inc., Nashville, Arkansas.

1984 Intensive Cultural Resources Survey of Selected Locations in the Longhorn Army Ammunition Plant, Karnack, Texas and Louisiana Army Ammunition Plant, Minden, Louisiana. Report No. 42. Archeological Assessments, Inc., Nashville, Arkansas.

1986 Investigations at 3HS28, the Jones Mill Site. Report No. 25. Archeological Assessments, Inc., Nashville, Arkansas.

1992 Archeological Investigations in the Lower Lee Creek Valley. Report No. 181. Archeological Assessments, Inc., Nashville, Arkansas.

2004 Cultural Resources Survey, "Nance" Cell Tower Location Saline County, Arkansas. Archeological Assessments, Inc., Nashville, Arkansas.

Bennett, W. J. Jr. and R. Bennett, Jr.

2002 Cultural Resources Investigations for Proposed Water Treatment and Distribution System, Glenwood and Vicinity, Pike County, Arkansas. Report No. 290. Archeological Assessments, Inc., Nashville, Arkansas.

Bennett, W. J., Jr. and A. F. Gettys

1980 Background and Literature Study for the Kiamichi Division of the Ouachita National Forest. Report No. 3. Archeological Assessments, Inc., Nashville, Arkansas. 
1986 Intensive Cultural Resources Survey on Six Proposed Exchange Tracts, Mena, Poteau, Oden, and Jessieville Ranger Districts, Ouachita National Forest. Archeological Assessments, Inc., Nashville, Arkansas.

Bennett, W. J., Jr. and W. H. Isenberger

2011 Cultural Resource Investigations Within Areas of Proposed Water System Renovations and Extensions, Black Springs, Norman, and Caddo Gap, Montgomery County, Arkansas. Report No. 363. Archeological Assessments, Nashville, Arkansas.

Bennett, W. J., Jr. and A. Lee

1986 Intensive Cultural Resources Survey on Seven Proposed Exchange Tracts, Ouachita National Forest. Report No. 61. Archeological Assessments, Inc., Nashville, Arkansas.

Bennett, W. J. Jr. and J. D. Northrip

2004 Cultural Resources Survey at Southwest Arkansas Electric REA Proposed Grannis Substation Site Polk County, Arkansas. Report No. 318. Archeological Assessments, Inc., Nashville, Arkansas.

Bennett, W. J., Jr., A. F. Gettys, and A. Lee

1986 Archeological Testing and Evaluation of 3MN298, Oden Ranger District. Report No. 26. Archeological Assessments, Inc., Nashville, Arkansas.

Bennett, W. J. Jr., J. D. Northrip, and W. Isenberger

2004 Intensive Cultural Resources Survey at Various Locations in the Ouachita National Forest Within the CDX GAS, LLC Hartford Tract Sebastian County, Arkansas. Report No. 317. Archeological Assessments, Inc., Nashville, Arkansas.

Bennett, W.J., Jr., et al.

1991 Archeological Investigations in the Lower Lee Creek Valley. Report No. 181. Archeological Assessments, Inc., Nashville, Arkansas.

Bense, J. A.

1994 Archaeology of the Southeastern United States. Academic Press, San Diego.

Bentley, J. H., J. A. Sitters, and W. N. Trierweiler

2017 A Cultural Resources Survey of 2.732 Acres at B. A. Steinhagen Lake, Sam Rayburn Reservoir, and Wright Patman Lake in Angelina, Bowie, Cass, Nacogdoches, San Augustine, and Tyler Counties, Texas. Poznecki-Camarillo, Inc. and AmaTerra Environmental, Inc., San Antonio and Austin.

Bergstrom, V. 
2011 Kisatchie National Forest Heritage Program Fiscal Year 2009 Annual Report. USDA, Kisatchie National Forest, Pineville, Louisiana. Report on file at the Louisiana Division of Archaeology, Department of Culture, Recreation, and Tourism, Baton Rouge.

2011 Kisatchie National Forest Heritage Program Fiscal Year 2010 Annual Report. USDA, Kisatchie National Forest, Pineville, Louisiana. Report on file at the Louisiana Division of Archaeology, Department of Culture, Recreation, and Tourism, Baton Rouge.

2012 PIT Project Investigates Drake Salt Works in Kistachie National Forest. Newsletter of the Louisiana Archaeological Society 39(3):18-19.

20132012 Field Work at Drake's Salt Works Complex (16NA11/17 \& 16WN30). Newsletter of the Louisiana Archaeological Society 40(3):14.

Bergstrom, V. R., S. L. Avery, R. McGrath, K. Knight, F. Woodral, J. Hill, L. Shores, and J. Jacobs

2000 Cultural Resources Survey for a Proposed Timber Harvest and Related Projects in Jack Pigeon Ecosystem Management Unit Compartments 223/224/225/226, Cold Springs Ranger District, Ouachita National Forest, Scott County, Arkansas. Ouachita Cultural Resources Report No. 195. Ouachita National Forest. Hot Springs.

Best, J. R.

1999 The Caddo Trace from Menard to Cleveland County, Arkansas. Field Notes (Newsletter of the Arkansas Archeological Survey) 290:3-4.

Beyer, G. E.

1896 The Mounds of Louisiana. Publications of the Louisiana Historical Society 1(4):12-32.

1898 The Mounds of Louisiana. Publications of the Louisiana Historical Society 2(1):7-27.

Bittle, W. E.

1957 Early Oklahomans. In Oklahoma, A Guide to the Sooner State, compiled by K. Ruth, pp. 18-25. University of Oklahoma Press, Norman.

Black, A., C. Brandimarte, and M. S. F. Tomka

1994 Archeological Investigations at Lake Tawakoni State Park, Hunt County, Texas. Texas Parks and Wildlife Department, Austin.

Black, S. L. and D. A. Story

2003 Woodland Cultures. http://www.texasbeyondhistory.net/tejas/ancestors/woodland.html. 
Accessed December 2012.

Blaine, J. C.

1988 Trade Hatchets from the Gilbert Site. The Record, Fiftieth Anniversary Edition 42(3):111-117. Dallas Archeological Society.

1992 A Summary and Discussion of Additional Findings at the Gilbert Site, an Eighteenth-Century Norteno Occupation in Rains County, Texas. Bulletin of the Texas Archeological Society 63:175-196.

Blake, L. W.

1994 Analysis of Rowland Clark Site Corn. Journal of Northeast Texas Archaeology 4:43-49.

Blazier, J. W., C. Kuttruff, N. Palmer, and A. Lunn

2009 A Phase I Cultural Resources Survey of Approximately 49,200 Linear Feet of New 20-Inch Natural Gas Pipeline (LIT 22), Bossier Parish, Louisiana. Weaver \& Associates, LLC, Memphis.

Bobalik, S. J.

1977 The Viper Marsh Site (Mc-205), McCurtain County, Oklahoma. Bulletin of the Oklahoma Anthropological Society 26:1-86.

1977 Archaeological Investigations at Proposed Clayton Reservoir 1976 Latimer, Pittsburg and Pushmataha Counties, Oklahoma. Archeological Resource Survey Reports No. 5. Oklahoma Archeological Survey, Norman.

1977 Radiocarbon Dates from Clayton Reservoir Area. Oklahoma Anthropological Society Newsletter 25(3):3.

1978 Archaeological Investigations at the Sallee G. Site, 34Pu99, Pushmataha County, Oklahoma. Studies in Oklahoma's Past No. 3. Oklahoma Archeological Survey, Norman.

Bobalik, S., C. Lintz, and R. Vehik

1978 The Clayton Lake Archaeological Project: 1978. Oklahoma Anthropological Society Newsletter 26(9):1-5.

Bohannon, C. F.

1962 Excavations at the Mineral Springs Site, Howard County, Oklahoma. The Arkansas Archeologist 3(10):7-9.

1966 Mineral Springs Site. In Caddoan Area Field Reports, 1962-1964 Seasons, edited by H. A. Davis, pp. 2-5. University of Arkansas Museum, Fayetteville. 
1973 Excavations at the Mineral Springs Site, Howard County, Arkansas. Research Series No. 5. Arkansas Archeological Survey, Fayetteville.

Bohon, K., T. N. Gannon, and A. Moerbe

2001 Final Report on Phase I Archaeological Investigations of the Lake Fort Smith Water Supply Project, Crawford County, Arkansas. Burns \& McDonnell, Inc., Kansas City.

Bond, C.

1970 Spinach Patch, 3FR1, and the River Bank Site, 3FR23, West-Central Arkansas. Report submitted to the National Park Service, Southeast Region, and the University of Arkansas Museum, Contract No. 14-107:911-14. On file at the Arkansas Archeological Survey, Fayetteville.

Bond, C. L. and W. E. Moore

1980 Archeological Investigations in the Davy Crockett National Forest. Cultural Resources Laboratory Report No. 1. Texas A\&M University, College Station.

Bonds, J.

2006 Art of the Ancient Caddo. Grove Hill Publishing, Leonard, Texas.

Bonine, M. L., R. S. Jones, and W. N. Trierweiler

2004 A Cultural Resource Inventory of 1,612 Acres at Lake Wright Patman and Lake Sam Rayburn, Texas. Ecological Communications Corporation, Austin.

Bourgeois, C. W., J. Mathews, J. Morehead, and L. H. Campbell 2007 Phase I Cultural Resource Investigations within a 64.7-Acre Parcel Proposed for Development, Bossier City, Louisiana. Prentice Thomas and Associates, Inc., Fort Walton, Florida.

Bousman, C. B. and A. L. Cheek (editors)

1978 Archeological Investigations at the Graham Site, At-90, 1977,1978.

Research Report No. 18. Archeological Research Associates, Tulsa.

Bousman, C. B., M. B. Collins, and T. K. Perttula

1988 Quaternary Geomorphology at Cooper Basin: An Archeological Inquiry. Reports of Investigations No. 55. Prewitt and Associates, Inc., Austin.

Bousman, C. B., et al.

1980 A Class II Survey of BLM Planning Unit I-08, Southeastern Oklahoma. Report prepared for BLM, Oklahoma Resource Area, by Archeological Research Associates, Tulsa, Oklahoma. Report on file at the Oklahoma Archeological Survey, University of Oklahoma, Norman. 
Boyd, B. E. and T. K. Perttula

2001 Initial Findings from the Archeological Investigations of the Hardin A Site (41GG69), Gregg County, Texas. Caddoan Archeology 12(1):5-10.

Boyd, J. L.

1967 Spectroscopic Analysis of Three Samples of Pigment from Burial 24 at the Haley Site, Miller County, Arkansas. Oklahoma Anthropological Society Newsletter 15(5):4.

Bozeman, S.

1984 Bibliography of Archaeological Articles Related to Caves \& Rockshelters in Oklahoma. Manuscript on file at the Oklahoma Archeological Survey, University of Oklahoma, Norman.

Brain, J. P.

1979 The Tunica Treasure. Papers No. 71. Peabody Museum of Archaeology and Ethnology, Harvard University, Cambridge.

1988 Tunica Archaeology. Papers No. 78. Peabody Museum of Archaeology and Ethnology, Harvard University, Cambridge.

Brain, J. P. and P. Phillips

1995 Shell Gorgets: Styles of the Late Prehistoric and Protohistoric Southeast. Peabody Museum of Archaeology and Ethnology, Harvard University, Cambridge.

Branam, C. and C. S. Spears

2005 An Archeological Survey of the Proposed West Taxiway and "Basin B" at Rogers Municipal Airport, Benton County, Arkansas. SPEARS Project Report 160. Spears Professional Environmental and Archeological Research Service, Inc., West Fork, Arkansas.

2005 A Cultural Resources Survey of the Proposed Oak Shores Boat Ramp on Lake Hamilton, Garland County, Arkansas. SPEARS Project Report 162. Spears Professional Environmental and Archeological Research Service, Inc., West Fork, Arkansas.

Brandon, J.

2006 Theft of the Cedar Grove Collections from the Arkansas Archeological Survey Southern Arkansas University Research Station. Field Notes (Newsletter of the Arkansas Archeological Survey) 332:2.

Bray, R. T. (editor)

1983 The Loftin Component, 23SN42. The Missouri Archaeologist 44:1-74. 
Brewington, R. L., J. E. Dockall, and H. J. Shafer

1995 Archaeology of 41MX5: A Late Prehistoric Caddoan Hamlet in Morris County, Texas. Reports of Investigations No. 1. Center for Environmental Archaeology, Texas A\&M University, College Station.

Briggs, A. K. and J. Malone

1970 Texarkana Reservoir Enlargement. Archeological Survey Report No. 7. Texas Historical Survey Committee, Austin.

Briscoe, J.

1976 A Preliminary Report on the Plantation Site, Mi-63, An Early Caddoan Settlement in Northern McIntosh County. Oklahoma Anthropological Society Newsletter 24(8):9-12.

1977 The Plantation Site (Mi-63), an Early Caddoan Settlement in Eastern Oklahoma. Papers in Highway Archaeology No. 3. Oklahoma Highway Archaeological Survey, Oklahoma City.

1991 Archeological Survey Report on the Asphalt Fuel Corporation Jumbo Lease, Pushmataha County, Oklahoma. Briscoe Consulting Services, Butler, Oklahoma.

1995 Cultural Resources Inventory on the OkTex Pipeline Company Proposed Abandonment of Pipeline OK-7, Red River County, Texas. Briscoe Consulting Services, Norman.

2013 Cultural Resources Report on the 4-Star Ranch Property, Pushmataha County, Oklahoma. Report prepared for Choctaw Forestry by James Briscoe, Norman, Oklahoma.

Briscoe, J. and R. Burkhalter

1991 Historical Archeological Investigations Along the Fort Gibson 12 Inch Waterline Project, Fort Gibson National Historic Site, Muskogee County, Oklahoma. Briscoe Consulting Services, Norman.

2014 (assemblers) Archeological Investigations on the Geokinetics Geophysical Inc. Panola Gap Phase 3B Seismic Study, Lake Wister, leFlore County, Oklahoma. Briscoe Archaeology, Norman.

Briscoe, J. M. and A. Hughes-Jones

1987 Surface Investigations of the Franklin Site (34Wa-3). Bulletin of the Oklahoma Anthropological Society 36:105-130.

Briscoe, J. and J. Munkres 
2002 Archeological Survey Report on the AEP Rogers to East Rogers $161 \mathrm{kV}$ Transmission Line Benton County, Arkansas. Briscoe Consulting Services, LLC., Norman.

Briscoe, J., C. LaFon, and J. Munkres

2003 Archeological Survey Report on the AEP Tontitown to Lowell 161kV Transmission Line Benton and Washington Counties, Arkansas. BCS Project Number 20-03. Briscoe Consulting Services, LLC., Norman.

Brock, A.

2009 Field School Excavations at Jones Mill, 2007. Field Notes (Newsletter of the Arkansas Archeological Society) 350:3-4.

Brock, A. and M. Reynolds

2007 New Radiocarbon Dates from 3CL593. Field Notes (Newsletter of the Arkansas Archeological Society) 339:10-11.

Brockington, P. E.

1984 The Coody Creek Site, a Late Caddo Village in Eastern Oklahoma. Soil Systems, Inc., Topeka, Kansas.

Brooks, R. L.

1976 An Intensive Archeological Survey of the Hope Sewerage Project. Project Report No. 156. Arkansas Archeological Survey, Fayetteville.

1976 Results of Archeological Testing in the Proposed Hope West Sewerage Treatment Plant. Arkansas Archeological Survey, Fayetteville.

1982 The Talihina Project. Archeological Resources Survey Report No. 15. Oklahoma Archeological Survey, Norman.

1985 A Review of "Pre-Columbian Shell Engravings from the Craig Mound at Spiro, Oklahoma (Parts 1 and 2)." Man 20:259-260.

1996 The Arkansas River Valley. A New Paradigm, Revisionist Perspectives and the Archaeological Record. Caddoan Archeology 7(1):17-27.

1997 Compliance, Preservation, and Native American Rights: Resource Management as a Cooperative Venture. In Native Americans and Archaeologists: Stepping Stones to Common Ground edited by N. Swidler, K. E. Dongoske, R. Anyon, and A. S. Downer, pp. 207-216. Altamira Press, Walnut Creek, California.

2006 From Mounds to Monasteries: A Look at Spiro and Other Centers Through the Use of Metaphor. Caddo Archeology Journal 15:41-58. 
2010 Analyzing the Arkansas River Caddoan Cultural Landscape. Caddo Archeology Journal 20:31-51.

2011 An Earspool from Near Ada, Pontotoc County, Oklahoma?? Caddo Archeology Journal 21:163-167.

2012 The Pickett Switch Site (34PN1) and the Presence of Arkansas River Basin Caddoans in East Central Oklahoma. Caddo Archeology Journal 22:77-95.

2012 Decisions in Landscape Setting Selection of the Prehistoric Caddo of Southeastern Oklahoma. In The Archaeology of the Caddo, edited by T. K. Perttula and C. P. Walker, pp. 335-362. University of Nebraska Press, Lincoln.

2012 A Response to Perttula and Cast. Plains Anthropologist 56 (220):369-370.

2013 Implications for Early Agriculture in Northeastern Oklahoma: A Collection of Tools from Lake Hudson, Mayes County, Oklahoma. Oklahoma Anthropological Society Bulletin 60:31-56.

Brooks, R. L. and J. E. Cox

2010 The Allcorn Site and its Relationship to the Arkansas River Basin Caddoan Area. Oklahoma Anthropological Society Bulletin 58:25-46.

2012 The Allcorn (34ML1) and Nagle (34OK4) Sites in Central Oklahoma and Their Relationship to the Arkansas River Caddoan Area. Plains Anthropologist 56(218):121-141.

Brooks, R. L. and D. Wyckoff

1985 lowa Connections in Caddoan Trade. Oklahoma Anthropological Society Newsletter 33(7):5-6.

Browman, D. L.

2013 Cultural Negotiations: The Role of Women in the Founding of Americanist Archaeology. University of Nebraska Press, Lincol.

Brown, D. O.

1988 Cultural Resources of the Proposed Kelsey Creek Reservoir, Upshur County, Texas. Horizon Environmental Services, Austin.

Brown, D. O. (editor)

1987 Archeology at Aquilla Lake 1978-1982 Investigations, Vols. I-III. Research Report No. 81. Texas Archeological Survey, The University of Texas at Austin. 
Brown, I.

1980 Salt and the Eastern North American Indian: An Archaeological Study. Bulletin No. 6. Lower Mississippi Survey, Peabody Museum, Harvard University, Cambridge.

Brown, J. A.

1964 Caddoan Archaeology-Spiro Focus Research Progress Report. Oklahoma Anthropological Society Newsletter 12(4):36.

1966 Spiro Studies, Vol. 1. Description of the Mound Group. University of Oklahoma Research Institute, Norman.

1966 Spiro Studies, Vol. 2. The Graves and Their Contents. University of Oklahoma Research Institute, Norman.

1966 Progress Report on Spiro. In Caddoan Area Field Reports, 1962-1964 Seasons, edited by H. A. Davis, pp. 57-68. University of Arkansas Museum, Fayetteville.

1967 New Radiocarbon Dates from the Spiro Site. Bulletin of the Oklahoma Anthropological Society 15:77-80.

1971 The Dimensions of Status in the Burials at Spiro. In Approaches to the Social Dimensions of Mortuary Practices, edited by J. A Brown, pp. 92112. Memoir No. 25. Society for American Archaeology, Washington, D.C.

1971 Spiro Studies, Vol. 3, Pottery Vessels. First Part of the Third Annual Report of Caddoan Archaeology-Spiro Focus Research. University of Oklahoma Research Institute, Norman.

1975 Spiro Art and Its Mortuary Contexts. In Death and the Afterlife in Precolumbian America, edited by E. P. Benson, pp. 1-32. Dumbarton Oaks Research Library and Collections, Washington, D.C.

1976 The Southern Cult Reconsidered. Midcontinental Journal of Archaeology 1:115-135.

1976 Spiro Studies, Vol. 4, The Artifacts. University of Oklahoma Research Institute, Norman.

1981 The Potential of Systematic Collections for Archaeological Research. Annals of the New York Academy of Sciences 376:65-76.

1981 The Search for Rank in Prehistoric Burials. In The Archaeology of Death, edited by R. Chapman, I. Kinnes, and K. Randsborg, pp. 25-37. Cambridge University Press, Cambridge. 
1983 Spiro Exchange Connections Revealed by Sources of Imported Raw Materials. In Southeastern Natives and Their Pasts, edited by D. G. Wyckoff and J. L. Hofman, pp. 129-162. Studies in Oklahoma's Past No. 11. Oklahoma Archeological Survey, Norman.

1984 Arkansas Valley Caddoan: The Spiro Phase. In Prehistory of Oklahoma, edited by R. E. Bell, pp. 241-263. Academic Press, New York.

1984 Prehistoric Southern Ozark Marginality: A Myth Exposed. Special Publications No. 6. Missouri Archaeological Society, Columbia.

1989 On Style Divisions of the Southeastern Ceremonial Complex - A Revisionist Perspective. In Southern Ceremonial Complex, Artifacts and Analysis. The Cottonlandia Conference, edited by P. E. Galloway, pp. 183-204. University of Nebraska Press, Lincoln.

1991 The Falcon and the Serpent, Life in the Southeastern United States at the Time of Columbus. In Circa 1492: Art in the Age of Exploration, edited by J. A. Levenson, pp. 529-534, 582-589. National Gallery of Art, Washington, D.C. and Yale University Press, New Haven.

1996 The Spiro Ceremonial Center. The Archaeology of Arkansas Valley Caddoan Culture in Eastern Oklahoma. 2 Vols. Memoir No. 29. Museum of Anthropology, University of Michigan, Ann Arbor.

2004 Exchange and Interaction to A.D. 1500. In Handbook for North American Indians, Volume 14, Southeast, edited by R. D. Fogelson, pp. 677-685. Smithsonian Institution, Washington, D.C.

2007 On the Identity of the Birdman within Mississippian Period Art and Iconography. In Ancient Objects and Sacred Realms: Interpretations of Mississippian Iconography, edited by F. K. Reilly, III and J. F. Garber, pp. 56-106. University of Texas Press, Austin.

2007 Sequencing the Braden Style within Mississippian Period Art and Iconography. In Ancient Objects and Sacred Realms: Interpretations of Mississippian Iconography, edited by F. K. Reilly, III and J. F. Garber, pp. 213-245. University of Texas Press, Austin.

2010 Cosmological Layouts of Secondary Burials as Political Instruments. In Mississippian Mortuary Practices: Beyond Hierarchy and the Representationist Perspective, edited by L. P. Sullivan and R. C. Mainfort, Jr., pp. 30-53. University Press of Florida, Gainesville. 
2010 The Regional Culture Signature of the Braden Art Style. In Visualizing the Sacred: Cosmic Visions, Regionalism, and the Art of the Mississippian World, edited by G. E. Lankford, F. K. Reilly, III and J. F. Garber, pp. 3763. University of Texas Press, Austin.

2012 Spiro Reconsidered: Sacred Economy at the Western Frontier of the Eastern Woodlands. In The Archaeology of the Caddo, edited by T. K. Perttula and C. P. Walker, pp. 117-138. University of Nebraska Press, Lincoln.

Brown, J. A. and R. E. Bell

1964 The First Annual Report of Caddoan Archaeology, Spiro Focus Research. University of Oklahoma Research Institute, Norman.

Brown, J. A. and D. H. Dye

2007 Severed Heads and Sacred Scalplocks; Mississippian Iconographic Trophies. In The Taking and Display of Human Body Parts as Trophies By Amerindians, edited by R. J. Chacon and D. H. Dye, pp. 278-298. Springer, New York.

Brown, J. A. and H. W. Hamilton

1965 The Cultural and Artistic World of Spiro and Mississippian Culture. In Spiro and Mississippian Antiquities from the McDonald Collection, pp. 11-47. The Museum of Fine Arts, Houston.

Brown, J. and J. Kelly

2012 The Importance of Being Specific: Theme and Trajectory in Mississippian Iconography. In Enduring Motives: The Archaeology of Tradition and Religion in Native America, edited by L. Sundstrom and W. DeBoer, pp. 210-234. University of Alabama Press, Tuscaloosa.

Brown, J. A. and J. D. Rogers

1989 Linking Spiro's Artistic Styles: The Copper Connection. Southeastern Archaeology 8:1-8.

1999 AMS Dates on Artifacts of the Southeastern Ceremonial Complex at Spiro. Southeastern Archaeology 18:134-141.

Brown, J. A., R. E. Bell, and D. G. Wyckoff

1978 Caddoan Settlement Patterns in the Arkansas River Drainage. In Mississippian Settlement Patterns, edited by B. D. Smith, pp. 169-200. Academic Press, New York.

Brown, K. M.

1975 The Tigert Site: An Early Caddoan Archeological Site. Texas Journal of Science 26(1-2):229-247. 
1976 Fused Volcanic Glass from the Manning Formation. Bulletin of the Texas Archeological Society 47:189-207.

Brownlow, R.

2002 An Intensive Cultural Resources Survey of a Proposed 17-Acre Tract to be Annexed to Kit McConnico Park Located in Lufkin, Angelina County, Texas. Horizon Environmental Services, Inc., Austin.

Bruce, R. E.

1991 Cultural Resources Survey of Compartment 08, Choctaw Ranger District, LeFlore County, Oklahoma. Forest Service Report 08-09-1-85a. Ouachita National Forest, Hot Springs.

Brues, A. M.

1958 Skeletal Material from the Horton Site. Bulletin of the Oklahoma Anthropological Society 6:27-32.

1959 Skeletal Material from the Morris Site, Ck-39. Bulletin of the Oklahoma Anthropological Society 7:63-70.

Bruseth, J. E.

1976 Archaeological Reconnaissance of an FEA Pipeline. Research Report No. 86. Archaeology Research Program, Southern Methodist University, Dallas.

1987 Late Holocene Environmental Change and Human Adaptive Strategies in Northeast Texas. Ph.D. dissertation, Department of Anthropology, Southern Methodist University, Dallas.

1991 Hudnall-Pirtle Site: An Early Caddoan Mound Complex in Northeast Texas. Caddoan Archeology Newsletter 2(3):9-15.

1992 Artifacts of the de Soto Expedition: The Evidence from Texas. Bulletin of the Texas Archeological Society 63:67-97.

1998 The Development of Caddoan Polities along the Middle Red River Valley of Eastern Texas and Oklahoma. In The Native History of the Caddo:

Their Place in Southeastern Archeology and Ethnohistory, edited by T. K. Perttula and J. E. Bruseth, pp. 47-68. Studies in Archeology 30. Texas Archeological Research Laboratory, The University of Texas at Austin.

Bruseth, J. E., and W. A. Martin (editors)

1987 The Bird Point Island and Adams Ranch Sites: Methodological and Theoretical Contributions to North Central Texas Archaeology. Richland 
Creek Archaeological Project Technical Series, Volume II. Institute of Earth and Man, Southern Methodist University, Dallas.

Bruseth, J. E. and T. K. Perttula

1980 Archaeological Research at Lake Fork Reservoir: Excavations at the Howle Site and Site Testing. Archaeology Research Program, Southern Methodist University, Dallas.

1981 Prehistoric Settlement Patterns at Lake Fork Reservoir. Texas Antiquities Permit Series, Report No. 2. Texas Antiquities Committee and Southern Methodist University, Austin and Dallas.

19911991 TAS Field School, The Sam Kaufman Site (41RR16), Red River County, Texas. Texas Archeology 35(2):3, 13-14, 19.

2006 Archeological Investigations at the Hudnall-Pirtle Site (41RK4): An Early Caddo Mound Center in Northeast Texas. Caddo Archeological Journal 15:57-158.

Bruseth, J. and B. Pierson

2004 Magnetometer Survey at the George C. Davis Site (41CE19). Current Archeology in Texas 6(1):7-9.

Bruseth, J. E., W. T. Pierson, and R. M. Johnson

2007 Large-Area Remote Sensing Coverage of Archaeological Sites with a DualTrack, Cart-Mounted Cesium Magnetometer. Journal of Field Archaeology 32:1-15.

Bruseth, J. E., J. T. Bagot, K. M. Banks, and M. A. McKinley

1977 Archaeological Research at Lake Fork Reservoir: Site Inventory and Assessment. Research Report No. 87. Archaeology Research Program, Southern Methodist University, Dallas.

Bruseth, J., J. Durst, R. Proctor, L. Banks, G. Sykes, and B. Pierson

2009 Investigations at the Gene and Ruth Ann Stallings Ranch Site (41LR297). Bulletin of the Texas Archeological Society 80:195-205.

Bruseth, J., M. Parsons, T. Middlebrook, and B. Martin 2000 Unprecedented Find Uncovered at the Ronald and Kay Morse Site (41SY27). Current Archeology in Texas 2(1):4-7.

Bruseth, J. E., D. E. Wilson, and T. K. Perttula 1995 The Sanders Site: A Spiroan Entrepot in Texas? Plains Anthropologist 40(153):223-236. 
Buchner, C. A., K. Oesch, N. H. Lopinot, G. S. Powell, C. P. Walker, J. Rocco de Gregory, N. P. Hermann, and S. L. Scott

2012 Archaeological Data Recovery at Foster Place (3LA27) and Site 3 LA290 for the Red River Rehabilitation Project (Item 9A-2), Lafayette County, Arkansas. PCI Report 31053. Panamerican Consultants, Inc., Memphis, Tennessee.

Buckner, H. F.

1878 Mounds in Indian Territory. American Antiquarian 1:14.

Buikstra, J. and D. Fowler

1975 An Osteological Study of the Human Skeletal Material from the Bentsen-

Clark Site. In The Bentsen-Clark Site, Red River County, Texas: A

Preliminary Report, by L. D. Banks and J. Winters, pp. 79-97. Special

Publication No. 2. Texas Archeological Society, San Antonio.

Burden, D., J. E. Dockall, A. E. Dase, and R. C. Fields

2015 Archeological Survey of 515 Acres in the Marshall Mine Expansion Area, Harrison and Panola Counties, Texas. Reports of Investigations No. 176. Prewitt and Associates, Inc., Austin.

Burden, D. A., S. L. Katauskas, and R. C. Fields

2012 National Register Testing at 41TT896 and 41TT906 and Archeological Survey of Three Parcels, FM 1000 Realignment Project (CSJ No. 122604-001), Titus County, Texas. Technical Report No. 91. Prewitt and Associates, Inc., Austin.

Burkhalter, R. J., C. Cojeen, and J. Ballenger

2000 Cultural Resources Inventory of the Proposed Muskogee Turnpike Project for Cardinal Engineering Inc., Muskogee, Haskell, and Le Flore Counties, Oklahoma. Report prepared for Cardinal Engineering, Inc. Cojeen Archaeological Services, Norman, Oklahoma.

Burnett, B. A.

1988 The Bioarchaeological Synthesis. In Human Adaptation in the Ozark and Ouachita Mountains, by G. Sabo III, A. M. Early, B. A Burnett, J. C. Rose, J. P Harcourt, and L. Vogele, Jr., pp. 193-220. Research Series No. 31. Arkansas Archeological Survey, Fayetteville.

1988 Bioarcheology of Standridge and the Middle Ouachita Caddoan. In Standridge: Caddoan Settlement in a Mountain Environment, by A. M. Early, pp. 143-152. Research Series No. 29. Arkansas Archeological Survey, Fayetteville. 
1989 A Bioarcheological Synthesis of the Ozark and Ouachita Mountains and the Arkansas River Valley, 1,300-1,000 B.P. to 300 B.P. Master's thesis, Department of Anthropology, University of Arkansas, Fayetteville.

1990 The Bioarcheological Synthesis of the Eastern Portion of the Gulf Coastal Plain. In The Archeology and Bioarcheology of the Gulf Coastal Plain, by D. A. Story, J. A. Guy, B. A. Burnett, M. D. Freeman, J. C. Rose, D. G. Steele, B. W Olive, and K. J. Reinhard, pp. 385-418. Research Series No. 38. 2 Vols. Arkansas Archeological Survey, Fayetteville.

1993 Adaptive Efficiency of Arkansas Populations. In Caddoan Saltmakers in the Ouachita Valley: The Hardman Site, edited by A. M. Early, pp. 187223. Research Series No. 43. Arkansas Archeological Survey, Fayetteville.

1999 The Bioarchaeological Synthesis of the Eastern Portion of the Gulf Coastal Plain. In Bioarcheology of the South Central United States, edited by Jerome C. Rose, pp. 102-132. Research Series No. 55. Arkansas Archeological Survey, Fayetteville.

Burnett, E. K.

1945 The Spiro Mound Collection in the Museum. Contributions from the Museum of the American Indian No. 14. Heye Foundation, New York.

Burns, S.

1994 Bioarchaeology of the Mackey Site in Southeastern Oklahoma. Master's thesis, Department of Anthropology, University of Oklahoma, Norman.

Burson, E.

2001 Archeological Test Excavations at Two Prehistoric Sites in the Cedar Springs Recreation Area at Lake O' the Pines, Upshur County, Texas. Miscellaneous Reports of Investigations No. 219. Geo-Marine, Inc., Plano.

Burson, E. and M. B. Cliff

2000 Cultural Resources Survey of Six Proposed Timber-cutting tracts at Wright Patman Lake, Bowie County, Texas and Lake O' the Pines, Marion and Upshur Counties, Texas. Miscellaneous Reports of Investigations No. 201. Geo-Marine, Inc., Plano.

Burton, R. J.

19691969 Excavations of the Oklahoma River Basin Survey. Oklahoma Anthropological Society Newsletter 17(7):3.

1971 The Archaeological View from the Harvey Site, Sq-18. Archaeological Site Report No. 21. Oklahoma River Basin Survey Project, University of Oklahoma, Norman. 
Burton, R. J. and R. Stahl

1969 The Harkey-Bennett Site, Sq 23, Sequoyah County, Oklahoma.

Archaeological Site Report No. 12. Oklahoma River Basin Survey Project, University of Oklahoma, Norman.

Burton, R. J., T. Bastian, and T. J. Prewitt

1969 The Tyler Site, Hs-11, Haskell County, Oklahoma. Archaeological Site Report No. 13. Oklahoma River Basin Survey Project, University of Oklahoma, Norman.

Burton, S. S.

1966 Analysis of Human Skeletal Material, Salt Lick Site (16SA37a). In Excavations in Toledo Bend Reservoir, $1964-65$ by B. B. McClurkan, W. T. Field, and J. N. Woodall, pp. 83-85. Papers of the Texas Archeological Salvage Project No. 8. Texas Archeological Salvage Project, The University of Texas at Austin.

1970 The Hugo Dam Site, Ch-112, Choctaw County, Southeast Oklahoma. Archaeological Site Report No. 16. Oklahoma River Basin Survey Project, University of Oklahoma, Norman.

Burton, S. S. and W. L. Neal

1970 The Dickson-Haraway Site, Sq-40, Sequoyah County, Oklahoma.

Archaeological Site Report No. 20. Oklahoma River Basin Survey Project, University of Oklahoma, Norman.

Bush, L. L.

2012 Macrobotanical Remains. In Archeology of the Nadaco Caddo: The View from the Pine Tree Mound Site (41HS15), Harrison County, Texas, by R. C. Fields and E. F. Gadus, pp. 728-772. Reports of Investigations Number 164. Prewitt and Associates, Inc., Austin, Texas.

2014 Plant Remains from Shelby Mound (41CP71), Camp County, Texas. Journal of Northeast Texas Archaeology 46:45-55.

2014 Analysis of the Paleobotanical Remains from the Musgano Site. In The Caddo Archaeology of the Musgano Site (41RK19) in the Sabine River Basin of East Texas, by T. K. Perttula, pp. 35-41. Special Publication No. 28. Friends of Northeast Texas Archaeology, Pittsburg and Austin.

2014 Eli Moores Site (41BW2) Plant Remains. In The Eli Moores Site, a $17^{\text {th }}$ to early $18^{\text {th }}$ Century Caddo Site on the Red River, Bowie County, Texas, edited by T. K. Perttula, pp. 63-73. Special Publication No. 31. Friends of Northeast Texas Archaeology, Austin and Pittsburg. 
2014 Macobotanical Plant Remains. In Testing and Data Recovery Excavations at Native American Sites along the U.S. Highway 271 Mount Pleasant Relief Route, Titus County, Texas, by R. C. Fields et al., pp. 613-643. Reports of Investigations No. 168. Prewitt and Associates, Inc., Austin.

2015 Plant Remains from Site 41PN175, Panola County, Texas. In Data Recovery Investigations: Murvaul Creek Site (41PN175), Panola County, Texas, by A. McKee et al., pp. 269-286. Report No. 165. Texas Department of Transportation, Environmental Affairs Division, Archeological Studies Program, Austin.

2016 Plant Remains from the Washington Square Mound site (41NA49), Nacogdoches, Texas. Journal of Northeast Texas Archaeology 70:77-90.

Bussey, S. D. and J. M. Briscoe

1991 Archaeological Survey and Deep Testing for Segments of the Natural Gas Pipeline Company of America Arkoma Lateral Pipeline, Bryan, Atoka, Pittsburg, and Latimer Counties, Southeast Oklahoma. Report prepared for the Natural Gas Pipeline Company of America, The Benham Group, Norman.

Bussey, S. D. and D. T. Hughes

1984 An Archeological Survey of a Coal Lease in Latimer County, Oklahoma. Report prepared for P \& K Company, Ltd. The Benham Group, Oklahoma City.

Butler, B. H.

1969 Analysis of the Human Skeletal Remains. In Archaeological Investigations at the Sam Kaufman Site, Red River County, Texas, edited by S. A. Skinner, R. K. Harris, and K. M. Anderson, pp. 115-136. Contributions in Anthropology No. 5. Department of Anthropology, Southern Methodist University, Dallas.

1969 The Skeletal Material from the Bison Site, Area B. In Archeological Excavations in the Toledo Bend Reservoir, 1966, by J. N. Woodall, pp. 8493. Contributions in Anthropology No. 3. Department of Anthropology, Southern Methodist University, Dallas.

Byington, E. S.

1912 Arkansas and Oklahoma Notes. The Archaeological Bulletin 3(3):81-82.

Byrd, K. M.

1980 Zooarchaeological Analysis of the Hanna Site: An Alto Focus Occupation in Louisiana. Louisiana Archeology 5:235-265.

Cain, D. A. 
2010 The Latest and Greatest in KNF. Newsletter of the Louisiana Archaeological Society 38(2):4.

2012 Native Peoples and Cultural Resource Management: KNF Caney Ranger District. Newsletter of the Louisiana Archaeological Society 39(3):17.

2012 Revisiting Lithic Scatters: A CRM Perspective. Southeastern Archaeology 31(2):207-220.

2013 Heritage Resource Work in the Kisatchie Archaeology "Zone" in 2012. Newsletter of the Louisiana Archaeological Society 40(3):15-16.

Caldwell, J. R.

1948 Norman Site, Ft. Gibson Reservoir, Wagoner County, Oklahoma. MS on file at the Sam Noble Oklahoma Museum of Natural History, University of Oklahoma, Norman.

Campbell, J., M. Stotts, and M. Miller

2010 Intensive Archeological Survey of Portions of the Proposed US 69/Loop 49 North Lindale Relief Route in Smith County, Texas, CSJ 0190-04-033. Archeology Series No. 201. Hicks and Company, Austin.

Campbell, J. A., R. Feit, R. Clark, N. Anderson, and J. A. McCellan 2003 Archeological Survey of State Highway 155 from Frankston to Pert, Anderson County, Texas. Archeology Series 116. Hicks and Company, Austin.

Campbell, L. J.

1987 Archaeological Testing in the Birds Creek Drainage, Fort Polk Military Reservation, Vernon Parish, Louisiana. Report of Investigations No. 154. New World Research, Inc., Pollock, Louisiana.

1990 Data Recovery at 16VN791, a Multi-Component Prehistoric Site in the Birds Creek Drainage, Fort Polk Military Reservation, Fort Polk, Louisiana. Report of Investigations No. 188. New World Research, Inc., Pollock, Louisiana.

Campbell, L. J., B. E. Holmes, and P. M. Thomas, Jr.

1978 Prehistoric and Historic Settlement in the Cane River Basin. New World Research, Inc., Pollock, Louisiana.

Campbell, L. J., C. S. Weed, M. T. Swanson, and J. E. Keller

1983 Background and Literature Review for Three Proposed Alternatives, Northwest Louisiana Water Supply Study. Report of Investigations No. 93. New World Research, Inc., Pollock, Louisiana. 
Campbell, T. N.

1936 A Study of Ornamentation in the Pottery of Prehistoric East Texas, with Special Attention Given to Designs. Master's thesis, Department of Anthropology, The University of Texas at Austin.

1961 Caddoan Radiocarbon Dates. Bulletin of the Texas Archeological Society 31:145-151.

Cande, K. H.

1988 A Cultural Resources Survey of the Proposed Walker Water Association Extensions, Columbia County, Arkansas. Project Report No. 678. Arkansas Archeological Survey, Fayetteville.

1996 Phase Two Test Excavations at 3PU398 within the North Little Rock Industrial Park, Pulaski County, Arkansas. Project Report No. 946. Arkansas Archeological Survey, Fayetteville.

2000 A Cultural Resources Survey of Five Proposed Multi-use Trails, Fayetteville City Parks, Washington County, Arkansas. SRP Final Report, Project 00-12. Submitted to the Fayetteville City Engineer.

2001 A Cultural Resources Survey of Portions of the Washington Water Authority North Central Extension within the Ozark National Forest, Boston Mountain Ranger District, Washington County, Arkansas. Final Report, Project 99-06. Submitted to the Milholland Company, Fayetteville

2001 A Phase I Cultural Resources Survey of the Proposed Northwest Arkansas Regional Airport Connector Road, Alternates 4 and 5, Benton and Washington Counties, Arkansas. Draft Report, Project 00-08. Submitted to Barnard Dunkelberg and Company, Tulsa.

2001 A Cultural Resources Survey of the Commerce Park Development, Fayetteville, Washington County, Arkansas. Final Report, Project 01-07. Submitted to Atkins Benham, Inc., Norman.

2001 A Cultural Resources Survey of the Alabam Transfer Station, Madison County, Arkansas. Final Report, Project 01-08. Submitted to Ozark Disposal Service, Kingston.

2001 A Phase I Cultural Resources Survey of the Proposed Northwest Arkansas Regional Airport Connector Road, Alternates 4 and 5, Benton and Washington Counties, Arkansas. Final Report, Project 00-08. Submitted to Barnard Dunkelberg and Company, Tulsa. 
2003 A Cultural Resources Survey of the Heritage East Phase II Subdivision, Washington County, Arkansas. Final Report, Project 03-10. Submitted to Concord Consultants LLC, Barling.

2003 A Cultural Resources Survey of the Heritage East Phase II Subdivision, Fayetteville, Washington County, Arkansas. Sponsored Research Program Project No. 03-10. Arkansas Archeological Survey, Fayetteville.

Cande, K. H., J. E. Hilliard, M. Williams, S. L. Scott, J. C. Dixon, G. J. Fritz, J. J. Lockhart, and J. E. Barnes

1993 Craddock Shelter (3CW2): Phase II Test Excavation and Analysis of the 1934 University of Arkansas Museum Collection, Crawford County, Arkansas. Project Report No. 788. Arkansas Archeological Survey, Fayetteville.

Cande, R. F.

1980 An Archeological Survey of the Proposed Water Supply Pipeline for the City of Mountain Pine, Garland County, Arkansas. Project Report No. 421. Arkansas Archeological Survey, Fayetteville.

1987 Cultural Resources Survey of the Proposed Water System Improvements for the City of Mount Ida, Montgomery County, Arkansas. Project Report No. 652. Arkansas Archeological Survey, Fayetteville.

Cande, R. F. and R. H. Lafferty III

1990 Cultural Resources Investigation on South Fork Watershed, Site I, and Intensive Testing at 3MN369, Montgomery County, Arkansas. MidContinental Research Associates, Inc., Lowell, Arkansas.

2004 Phase I Archeological Survey of the Proposed Sage House Transitional Housing Project, Fayetteville, Washington County, Arkansas. MCRA Report 2004-4. Mid-Continental Research Associates, Inc., Lowell, Arkansas.

Cantley, C. E.

1993 Data Recovery at Site 16VN794: Investigations into Site Formation Processes and the Cultural Sequence of West Central Louisiana. Technical Report No. 119. New South Associates, Stone Mountain, Georgia.

Carlson, S. B. and J. E. Corbin

1999 Mission Dolores Revisited. Bulletin of the Texas Archeological Society 70:49-57.

Carlson, S. B. and K. L. Quinn 
1996 Archaeological Investigations at Mission Dolores de los Ais (41SA25), 1995-1996, San Augustine County, Texas. Technical Report No. 1. Historic Sites Research, College Station.

Carney, G. M.

1993 The Evidence and Character of Exchange between Arkansas Basin Caddoans and Plains Villagers, A.D. 900-1500. M.S. thesis, University of Oklahoma, Norman.

Carpenter, S. M.

2002 Archaeological Survey of the 24.5-Mile Entergy Water Supply and Discharge Pipeline, Harrison and Gregg Counties, Texas. Cultural Resource Report No. 02-291. SWCA, Inc., Austin.

2014 The Grand Parallel: A Consistent Latitude of Late Woodland and Caddo Multimound Centers in the Lower Mississippi Valley and Eastern Texas. Southeastern Archaeology 33(1):123-135.

Carpenter, S. M. and D. K. Utley

1996 Dust on the Water. The Cultural Resources of Daingerfield State Park. Report 96-6. Texas Parks and Wildlife Department, Cultural Resources Program, Austin.

Carpenter, S., et al.

2010 Cultural Resource Inventory of the Keystone XL Pipeline Project: Gulf Coast Segment in Oklahoma. Report prepared for the U.S. Department of State by SWCA Environmental Consultants, Austin.

Carpenter, S., et al.

2010 Cultural Resource Inventory of the Keystone XL Pipeline Project: Gulf Coast Segment in Texas. Cultural Resources Report No. 2008-392. Report prepared for the U.S. Department of State by SWCA Environmental Consultants, Austin.

Carter, C. E.

1995 Archaeology, The Caddo Indian Tribe, and the Native American Graves Protection and Repatriation Act. Journal of Northeast Texas Archaeology 5:4-8.

1997 Straight Talk and Trust. In Native Americans and Archaeologists: Stepping Stones to Common Ground, edited by N. Swidler, K. E. Dongoske, R. Anyon, and A. S. Downer, pp. 151-155. Altamira Press, Walnut Creek, California.

2008 A Decade of Straight Talk and Trust. Caddo Archeology Journal 18:1-4. 
Cartledge, T. R.

1970 The Tyler-Rose Site and Late Prehistory in East Central Oklahoma. Archaeological Site Report No. 19. Oklahoma River Basin Survey Project, University of Oklahoma, Norman.

Cast, R.

1999 Working Together: A Tribal Historic Preservation Officer's Perspective. Current Archeology in Texas 1:8-9.

2005 Perspectives: The Caddo Tribe of Oklahoma. In Assessment of Properties of Traditional Religious and Cultural Importance to the Signatory Tribes of the Native American Historical Initiative: Reconnecting to the Lands of the Louisiana Army National Guard, edited by D. W. Morgan, pp. 129-136. Cultural Resource Office, Northwestern State University, Natchitoches.

2007 Documentation of a Native American Church Altar in Caddo County, Oklahoma. Journal of Northeast Texas Archaeology 26:168-178.

2016 Cultural Resource Survey Report: Sawyer Ranch-Sawyer, Oklahoma, Choctaw County, Oklahoma. Historic Preservation Department, Choctaw Nation of Oklahoma, Durant.

Cast, R. and T. K. Perttula

2002 The Long-Term Looting of Caddo Indian Sites on Federal Property in Northeastern Texas. CRM 25(2):26-28.

Cast, R. L., B. Gonzalez, and T. K. Perttula

2010 Claiming Respect for Ancestral Remains: Repatriation and the Caddo Nation of Oklahoma. American Anthropological Association Newsletter 51(3):7-8.

2010 The Caddo Nation, Archaeology, and NAGPRA. In Archaeology of Louisiana, edited by M. A. Rees, pp. 211-222. Louisiana State University Press, Baton Rouge.

2012 Claiming Respect for Ancestral Remains: Repatriation and the Caddo Nation of Oklahoma. In Experiencing Race, Class, and Gender in the United States, $6^{\text {th }}$ Edition, by R. Fiske-Rusciano, pp. 426-428. McGraw Hill, New York.

Cast, R. L., B. Nelson, and T. K. Perttula

2014 Archeological Survey of the Proposed Bradley Oaks Project on Wolf Creek in Anderson County, Texas. Report of Investigations No. 2. Native Heritage Preservation Associates, LLC, Mustang, Oklahoma.

Cast, R., T. K. Perttula, B. Gonzalez, and B. Nelson 
2005 A Rediscovery of Caddo Heritage: The W. T. Scott Collection at the American Museum of Natural History. Caddoan Archeology Journal 14:516.

2006 A Rediscovery of Caddo Heritage. Archaeologies: The Journal of the World Archaeological Congress 2(1):45-51.

2006 Documentation of Caddo Ceramic Vessels from 41WD60, Wood County, Texas. Historic Preservation Program, Caddo Nation of Oklahoma, Binger, Oklahoma.

Cecil, L. G.

2011 Descriptive and Petrographic Report and Summary for Pottery from 41HY163, Zapotec. In Prehistoric Life, Labor, and Residence in Southeast Central Texas: Results of Data Recovery at 41HY163, the Zapotec Site, San Marcos, Texas, edited by J. C. Lohse, pp. 173-188. Archaeological Studies Report No. 18. Center for Archaeological Studies, Texas State University-San Marcos.

2012 Petrographic Analysis of Pottery and Clay Samples from the Pine Tree Mound Site (41HS15), Harrison County, Texas. In Archeology of the Nadaco Caddo: The View from the Pine Tree Mound Site (41HS15), Harrison County, Texas, edited by R. C. Fields and E. F. Gadus, pp. 797826. Reports of Investigations No. 164. Prewitt and Associates, Inc., Austin.

Cecil, L. G. (editor)

2010 Archaeological Investigations at the Sterne-Hoya Home (41NA144), Nacogdoches County, Texas. Stephen F. Austin State University, Nacogdoches.

Chafin-Lohse, M. and T. Anderson

1979 The Hen House Ridge Site (41JP65): Analysis of Excavations. Rice University, Houston.

Chapman, C. H. and R. E. Pangborn

1962 The Broyles Site, 23CE123. In A Preliminary Investigation of the Stockton Reservoir Area, by C. H. Chapman, M. J. Powell, J. R. Bradham, and R. E. Pangborn, pp. 98-140. American Archaeology Division, University of Missouri-Columbia.

2011 The Broyles Cairn, 23CE123. The Missouri Archaeologist 72:5-20.

Chapman, S. 
1999 Phase II Archaeological Testing of Site 16WE334 Proposed Well Pad Locality Bayou Bodcau Wildlife Area Webster Parish, Louisiana.

Panamerican Consultants, Inc., Memphis.

2004 Cultural Resources Survey of Three Items in the Ouachita River Hot Spring County, Arkansas as Part of a Section 1135 Environmental Restoration Project. Panamerican Consultants, Inc., Memphis.

Chapman, S. and E. Peacock

1998 Phase I Archaeological Survey Proposed Fiber-Optic Cable Line Bossier and Caddo Parishes, Louisiana. Panamerican Consultants, Inc., New Orleans.

Chari, S.

2010 Journeys to Repatriation: 15 Years of NAGPRA Grants, 1994-2008. Museum Anthropology 33(2):210-217.

Cheatham, S.

1992 The Caddo House Reconstruction. Bulletin of Primitive Technology 1(3):22-24.

Cheatham, T. H., Jr.

1983 Volunteerism at Work in Southwest Arkansas: The Salvage Operation in the Plaza of the Skulls at the Crenshaw Site and the McKinney Bayou Survey Project. Field Notes (Arkansas Archeological Society) 193:3-5.

Cheek, A. L. (editor)

1975 Test Excavations at At-87, At-88, and At-91, Atoka County, Oklahoma. Archeological Research Assessments, Tulsa.

Cheek, A. L., C. D. Cheek, D. K. Leehan, K. C. Duncan, B. L. Losher, and J. E. Baker

1974 An Archeological Assessment of the Proposed McKinney - Buzzard Watershed, McCurtain County, Oklahoma. Report to USDA, SCS, Agreement No. AG40 scs 01740. Archeological Research Associates, Tulsa, Oklahoma.

Cheek, A. L., C. D. Cheek, S. Hackenburger, T. Jones, W. M. Jones, and K. Leehan

1974 An Archaeological Survey of the Upper Muddy Boggy Watershed, Pontotoc, Coal, and Hughes Counties, Oklahoma. Report prepared for the USDA, Soil Conservation Service, under contract \# AG40565-01454. Department of Sociology and Anthropology, University of Tulsa, Tulsa, Oklahoma.

Cheek, A. L., C-B. Stewart, and K. C. Duncan 
1976 A Preliminary Assessment of the Archeological Resources in Southern Oklahoma. Research Report No. 16. Archeological Research Associates, Tulsa.

Cheek, C. D.

1977 A Cultural Assessment of the Archeological Resources in the Fort Gibson Lake Area, Eastern Oklahoma. Research Report No. 15. Archeological Research Associates, Tulsa.

Cheek, C. D., S. Bearden, W. Young, and C. B. Bousman

1980 Archeological Investigations at the Graham Site, 344t-90, 1975, 1976, and 1978. Research Report No. 23. Archeological Research Associates, Tulsa.

Chelf, C.

1939 A Group Burial from Lamar County. Information Circular No. 6. Texas Memorial Museum, Austin.

Chenault, D. C., C. S. Spears, and T. Gannon

1996 An Archeological Survey of 3,857 Acres in the Womble and Fourche Ranger Districts of the Ouachita National Forest, Montgomery and Yell Counties, Arkansas. Project Report 110. Spears Professional Environmental and Archeological Research Service, Inc., West Fork, Arkansas.

Chenault, D. C., C. S. Spears, and A. L. Moerbe

1995 An Archeological Survey of 3.1 Miles of a Proposed Pipeline for the Albemarie Corporation, Columbia and Lafayette Counties, Arkansas. Project Report 109. Spears Professional Environmental and Archeological Research Service, Inc., West Fork, Arkansas.

Chenault, D. C., C. S. Spears, L. Porter, and L. G. Santeford 1995 An Archeological Survey of 660 Acres in the Womble District of the Ouachita National Forest, Montgomery and Polk Counties, Arkansas. Project Report 105. Spears Professional Environmental and Archeological Research Service, Inc., West Fork, Arkansas.

Clancey, P. M.

1985 The Carden's Bottom Puzzle Elucidated. Master's thesis, Department of Anthropology, University of Arkansas, Fayetteville.

Clark, C.

1980 Bone Tool Manufacture and Use by Prepottery Occupants of the McCutchan-McLaughlin Site. Bulletin of the Oklahoma Anthropological Society 29:19-48. 
1984 Archeological Evidence for Mountain Lion (Felis concolor) at Lake Wister. Oklahoma Anthropological Society Newsletter 32(6):4-5.

1987 Subsistence Intensification in Deer Resource Use at the McCutchanMcLaughlin (34Lt-11) Site, Latimer County, Oklahoma. Master's thesis, Department of Anthropology, University of Oklahoma, Norman.

Clark, J. W. and J. E. Ivey

1974 Archaeological and Historical Investigations at Martin Lake, Rusk and Panola Counties, Texas. Research Report 32. Texas Archeological Survey, Austin.

Cleland, C. E.

1965 Faunal Remains from Bluff Shelters in Northwest Arkansas. The Arkansas Archeologist 6(2-3):39-63.

Clement, C. O., R. M. Grunden, S. D. Smith, C. L. Abrams, and J. S. Quattlebaum

1995 Results of a 4,000 Acre Archeological Survey, Barksdale Air Force Base, Bossier Parish, Louisiana. University of South Carolina, South Carolina Institute of Archaeology and Anthropology, Cultural Resources Consulting Division, Columbia.

Clements, F. E.

1939 Spiro Shell Gorget. Oklahoma Prehistorian 2(2):1.

1945 Historical Sketches of Spiro Mound Contributions from the Museum of the American Indian. No. 14. Heye Foundation, New York.

Cliff, M. B.

1997 The Middle Caddoan Period in the Lower Sulphur River Area. Journal of Northeast Texas Archaeology 9:9-16.

Cliff, M. B. (editor)

1994 Cultural Resources Survey of a Portion of the White Oak Creek Mitigation Area (WOCMA), Bowie, Cass, and Morris Counties, Texas: 1990-1992. Report of Investigations No. 2, White Oak Creek Mitigation Area Archeological Technical Series. Geo-Marine, Inc., Plano.

Cliff, M. B., and S. M. Hunt

1995 Cultural Resources Testing of Three Sites within the Moist Soils Management Area (MSMA) of the White Oak Creek Mitigation Area (WOCMA), Cass County, Texas. Report of Investigations No. 3, White Oak Creek Mitigation Area Archeological Technical Series. Geo-Marine, Inc., Plano. 
1998 Intensive Pedestrian Survey at Lake O' the Pines and Wright Patman Lake, Bowie, Cass, and Marion Counties, Texas: 1997. Miscellaneous Report of Investigations No. 154. Geo-Marine, Inc., Plano.

Cliff, M. B. and T. K. Perttula

2002 Results of National Register Investigations Conducted on Site 41PN175, Panola County, Texas. Report No. 32. Archeological Studies Program, Environmental Affairs Division, Texas Department of Transportation, Austin.

2002 Results of National Register Investigations Conducted on Site 41WD632, Wood County, Texas. Report No. 42. Archeological Studies Program, Environmental Affairs Division, Texas Department of Transportation, Austin.

Cliff, M. B. and D. E. Peter

1989 Test Excavations at Sites 16WE233 and 16WF236, Louisiana Army Ammunition Plant, Webster Parish, Louisiana. Report of Investigations No. 2, LAAP Archeological Technical Series. Geo-Marine, Inc., Plano.

Cliff, M. B. and D. E. Peter (editors)

1990 Intensive Archeological Survey and Archival Investigations at the Red River Army Depot and Lone Star Army Ammunition Plant, Bowie County, Texas. RRAD/LSAAP Archeological Technical Series, Report of Investigations No. 2. Geo-Marine, Inc., Plano.

1992 Cultural Resources Survey of the Moist Soils Management Area, White Oak Creek Mitigation Area (WOCMA), Cass County Texas. White Oak Creek Mitigation Area. Archeological Technical Series, Report of Investigations No. 1. GeoMarine, Inc., Plano.

1994 Test Excavations at the Coney Branch and Caney Branch II Sites (16B0198 and 16B0200), Louisiana Army Ammunition Plan, Bossier Parish, Louisiana. Report of Investigations No. 5, LAAP Archeological Technical Series. Geo-Marine, Inc., Plano.

1994 Archaeological Survey of Selected Portions of the Longhorn Army Ammunition Plant, Harrison County, Texas 1989-1992. Miscellaneous Report of Investigations No. 38. Geo-Marine, Inc., Plano.

1994 Cultural Resources Survey of 2,226 Hectares Within the Red River Army Depot and Lone Star Army Ammunition Plan, Bowie County, Texas. RRAD/LSAAP Archeological Technical Series, Report of Investigations No. 4. Geo-Marine, Inc., Plano.

Cliff, M. B. and E. C. Sills 
2005 Results of National Register Investigations Conducted on Sites 41RK295 and 41RK304, Rusk County, Texas. PBS\&J, Austin.

Cliff, M. B., C. Carter, and L. Verrett

1974 Archaeological Survey of the Welsh Power Plant. Archaeology Research Program, Southern Methodist University, Dallas.

Cliff, M. B., M. Green, S. Hunt, D. Shanabrook, and D. Peter

1996 Excavations in Area C of the Unionville Site (41CS151), White Oak Creek Mitigation Area (WOCMA), Cass County, Texas. Report of Investigations No. 4, White Oak Creek Mitigation Area Archeological Technical Series. Geo-Marine, Inc., Plano.

Cliff, M. B., S. M. Hunt, M. M. Green, R. Proctor, F. B. Largent, Jr., and W. J. Autin

1997 Geomorphological Investigations and Inventory of Cultural Resources along and near the Bowie County Levee, Bowie County, Texas: 1996. Miscellaneous Report of Investigations No. 139. Geo-Marine, Inc., Plano.

Cliff, M. B., S. M. Hunt, F. Kent, M. M. Green, and D. E. Peter 1995 Archeological Survey of 1993-1994 Timber Harvesting Areas, Longhorn Army Ammunition Plant, Harrison County, Texas. Miscellaneous Report of Investigations No. 71. Geo-Marine, Inc., Plano.

Cliff, M. B., S. M. Hunt, D. Pleasant, R. Proctor, and H. B. Ensor 1996 Cultural Resources Survey of 600 Acres at Wright Patman Lake, Bowie and Cass Counties, Texas. Miscellaneous Report of Investigations No. 108. Geo-Marine, Inc., Plano.

Cliff, M. B., S. M. Hunt, and F. B. Largent, Jr.

1995 A Cultural Resource Survey of 680 Acres in the Vicinity of Willow Chute Bayou, Bossier Parish, Louisiana. Miscellaneous Report of Investigations No. 85. Geo-Marine, Inc., Plano.

Cliff, M. B., S. K. Mbutu, S. M. Hunt, and F. B. Largent, Jr.

1996 National Register Evaluation of the Hickory Ridge Site (34Hs-75), Haskell County, Oklahoma. Miscellaneous Report of Investigations No. 126. GeoMarine, Inc., Plano.

Cliff, M. B., J. A. Perry, and R. J. Norris

2009 Intensive Archeological Survey for the Texas Department of Transportation Bridge Replacement and Roadway Widening of US 271 2.11 Miles North of FM 1896 to 1.83 Miles South of FM 1896, Titus County, Texas. Document No. 060338. PBS\&J, Dallas.

Cliff, M. B., E. C. Sills, L. Acuna, and P. Dering 
2004 Results of National Register Investigations Conducted on Site 41RK328, Rusk County, Texas. Document No. 040010. PBS\&J, Dallas.

Cliff, M. B., E. C. Sills, T. K. Perttula, and P. Dering

2004 National Register Testing of Sites 41HE14, 41HE139, and 41HE343 within Proposed FM 3506 Right of Way, Henderson County, Texas. Report No. 60. Archeological Studies Program, Texas Department of Transportation, Austin.

Cliff, M. B., W White, S. Hunt, D. Pleasant, and G. Shaw

1996 Cultural Resources Survey of 5,000 Acres within the White Oak Creek Mitigation Area (WOCMA), Bowie, Morris, and Titus Counties, Texas: 1993-1994. Report of Investigations No. 5, White Oak Creek Mitigation Area Archeological Technical Series. Geo-Marine, Inc., Plano.

Cobb, $\mathrm{H}$.

1983 A Burial at the Sam Kaufman Site. The Record 39(1):3-7, 9. Dallas Archeological Society, Dallas.

Cobb, J. E.

1976 The Functional Analysis of Late Prehistoric Remains from Bonkte Shelter. Master's thesis, Department of Anthropology, University of Arkansas, Fayetteville.

Coble, J. D. and E. Z. Waddell

1991 Phase 1 Cultural Resource Survey of the Proposed Alltel Subsurface Telephone Line Project Right-of-Way the Ouachita National Forest, Caddo and Womble Districts, in Montgomery, Garland and Hot Springs Counties, Arkansas. Report No. 90-12. Spears Professional Environmental and Archeological Research Service, Inc., West Fork, Arkansas.

Cockrell, B. and V. R. Bergstrom

2008 Archaeological Inventory of 1,554 Acres within the Caney River District, KIsatchie National Forest, Webster Parish, Louisiana. Kisatchie National Forest, Pineville.

Cody, M. C., C. Nielsen, S. M. Carpenter, L. I. Acuna, J. McGilvray, A. N. Young, and M. Garcia

2014 Cultural Resources Inventory of Areas Permitted Under the Antiquities Code of Texas on the Keystone Pipeline Gulf Coast project, Fannin and Lamar Counties, Texas. Cultural Resources Report No. 14-631. SWCA Environmental Consultants, Austin.

Cogswell, J. W., H. Neff, and M. D. Glascock 
2004 Chemical Variation in Northeast Texas Ceramics. In The Oak Hill Village Site (41RK214), Rusk County, Texas, by R. Rogers and T. K. Perttula, pp. 307-321. Document No. 030083. PBS\&J, Austin.

2005 Instrumental Neutron Activation Analysis of Ceramics from Residential Areas at the Pilgrim's Pride Site. In Archeological Investigations at the Pilgrim's Pride Site (41CP304), a Titus Phase Community in the Big Cypress Creek Basin, Camp County, Texas, edited by T. K. Perttula, pp. 148-161. 2 Vols. Report of Investigations No. 30. Archeological \& Environmental Consultants, LLC, Austin.

2008 Chemical Variation in Northeastern Texas Ceramics, Including Analyses of Sherds from Four Red River County Sites, in "The Archeology of the Roitsch Site (41RR16), an Early to Historic Caddo Period Village on the Red River in Northeast Texas," In Collected Papers from Past Texas Archeological Society Summer Field Schools, edited by T. K. Perttula, pp. 402-413. Special Publication No. 5. Texas Archeological Society, San Antonio.

Cogswell, J. W., H. Neff, M. Glascock, and T. K. Perttula

2005 Instrumental Neutron Activation Analysis of Vessel Ceramics from the Titus Phase Cemetery. In Archeological Investigations at the Pilgrim's Pride Site (41CP304), a Titus Phase Community in the Big Cypress Creek Basin, Camp County, Texas, edited by T. K. Perttula, pp. 281-283. 2 Vols. Report of Investigations No. 30. Archeological \& Environmental Consultants, LLC, Austin.

Cojeen, C. and A. Milam

1993 Report of Limited Testing of Archaeological Site Hs182 Within the Proposed Impact Area of Enron Oil and Gas Company's Joann \#21-1 Well Pad Located in Haskell County. Cojeen Archaeological Services, Norman.

Cojeen, C., J. Briscoe, and R. Burkhalter

1995 Limited Testing and Mitigative Action at Site 34Lt-280 for Barrett Resources Corporation Prior to the Construction of the Glenn Unit Well Pad Located in Latimer County, Oklahoma. Cojeen Archaeological Services, Norman.

Colby, G. R.

1997 Analysis of Dental Abscess Formation in a Texas Hunter-Gatherer and a Texas Agricultural Population. Bulletin of the Texas Archeological Society 68:179-189.

Cole, N. M. 
1975 Early Historic Caddoan Mortuary Practices in the Upper Neches Drainage, East Texas. Master's thesis, Department of Anthropology, The University of Texas at Austin.

Coleman, N. and R. Shelton

2012 Cultural Resources Survey of the Benham Interceptor Sanitary Sewer Line Route, Mineola, Texas. Cultural Resources Report 2012-30. AR Consultants, Inc., Dallas.

Coleman, R. E.

1991 Cultural Resources Survey for Proposed Timber Harvests in Compartments 5, 13, and 17, Caddo Ranger District, Garland County, Arkansas. Ouachita Cultural Resources Report No. 18. Ouachita National Forest, Hot Springs.

1992 Cultural Resources Survey for Proposed Ground Preparation Activities on Acquired Lands in Caddo Ranger District, Ouachita National Forest, Garland, Montgomery, and Polk Counties, Arkansas. Ouachita Cultural Resources Report No. 57. Ouachita National Forest, Hot Springs.

1992 Cultural Resources Survey for Proposed Timber Harvests in Compartments 7, 8, 69, and 81, Caddo Ranger District, Garland and Montgomery Counties, Arkansas. Ouachita Cultural Resources ReportNo. 25. Ouachita National Forest, Hot Springs.

2001 Road Easement to Access Private Property (PIF). Forest Service Project 08-09-08-664. Ouachita National Forest, Hot Springs.

2002 Archeological Investigations at the Rocky Shoals (3MN1708) Womble Ranger District, Ouachita National Forest, Montgomery County, Arkansas. Ouachita Cultural Resources Report No. 167. Ouachita National Forest, Hot Springs.

2002 Lower Lake Winona Watershed. Forest Service Project 08-09-11-271. Ouachita National Forest, Hot Springs.

2002 Archaeological Investigations at Brier Creek (3MN2181), Montgomery County, Arkansas. Ouachita Cultural Resources Report No. 207. Ouachita National Forest, Hot Springs.

2003 Construction of a Drain Field Loop B in the Charleton Recreation Area, Compartment 1614, Womble Ranger District, Montgomery County. Ouachita Cultural Resources Report No. 08-09-10-511. Ouachita National Forest, Hot Springs.

2003 Restoration of Pucket Bend Wildlife Opening, Compartment 1646, Womble Ranger District, Montgomery County. Ouachita Cultural 
Resources Report No. 08-09-10-510. Ouachita National Forest, Hot Springs.

2004 Archeological Investigation in Compartment 23, Caddo Ranger District, Ouachita National Forest, Garland, Hot Spring, and Montgomery Counties, Arkansas. Ouachita Cultural Resources Report No. 231. Ouachita National Forest, Hot Springs.

2004 Statehouse Mountain Fireline Survey, Caddo Ranger District, Montgomery County. Ouachita Cultural Resources Report No. 08-09-12-326. Ouachita National Forest, Hot Springs.

2004 Compartment 92 Plantation Thinning, Caddo Ranger District, Montgomery County. Ouachita Cultural Resources Report No. PN-05-012. Ouachita National Forest, Hot Springs.

2005 Special Use Permit Womble Ranger District, Montgomery County. Ouachita Cultural Resources Report No. PN05-013. Ouachita National Forest, Hot Springs.

2006 Keep the Change-The Organization of Technology in the upper Little Missouri River Basin Excavation at Site 3MN2452, Little Missouri Falls, Montgomery County, Arkansas. Ouachita Cultural Resources Report No. 256. USDA Forest Service, Ouachita National Forest, Hot Springs, Arkansas.

Coleman, R. E. and D. Whitmire

2008 Archeological Investigation in Mountain View Watersheds, Caddo Ranger District, Ouachita National Forest, Montgomery County, Arkansas. Ouachita Cultural Resources Report 286. USDA Forest Service, Ouachita National Forest, Hot Springs, Arkansas.

Coleman, R. E., S. L. Avery, and L. D. Haikey

1992 Cultural Resources Survey for Phase II New Perspectives Research Stands, Ouachita National Forest, Montgomery, Garland, Polk, Scott, and Yell Counties, Arkansas and LeFlore County, Oklahoma. Ouachita Cultural Resources Report No. 23. Ouachita National Forest, Hot Springs.

Coleman, R. E., R. Beaty, T. Ogle, and C. Wright

2006 Archeological Assessment for the East Watersheds, Womble Ranger District, Ouachita National Forest, Garland County, Arkansas. Ouachita Cultural Resources Report 242. USDA Forest Service, Ouachita National Forest, Hot Springs, Arkansas.

Coleman, R. E., S. B. Carlson, and D. L. Carlson 
1984 An Archeological Reconnaissance in Selected Areas of Western Shelby County, Texas. Archeological Surveys No. 3. Texas A\&M University, College Station.

Coleman, R. E., M. Etchieson, T. K. Perttula, and S. Marceaux

2013 Ouachita National Forest: An Archeological Overview. Ouachita Cultural Resources Report 400. Ouachita National Forest, Hot Springs.

Coleman, R. E., J. Fryar, and A. C. Wallace

2006 Reforestation in Brooks Hollow: Documenting the Low Visibility Archeological Record, Caddo Ranger District, Ouachita National Forest, Pike County, Arkansas. Ouachita Cultural Resources Report No. 243. USDA, Forest Service, Ouachita National Forest, Hot Springs, Arkansas.

Coleman, R. E., J. Fryar, B. Rowland, A. Strothers, and S. Belcher 2000 Archeological Assessment for Walnut Fork Watershed, Womble Ranger District, Ouachita National Forest, Garland and Montgomery Counties, Arkansas. Ouachita Cultural Resources Report 193. Ouachita National Forest, Hot Springs.

Coleman, R. E., J. Fryar, S. Belcher, J. Jacobs, C. Johnson, E. Stovall, B. Rowland, A. Strothers, and S. Wagner

2004 Archeological Assessment for Fulton Branch Watershed, Womble Ranger District, Ouachita National Forest, Montgomery County, Arkansas. Ouachita Cultural Resources Report 198. Ouachita National Forest, Hot Springs.

Coleman, R., P. S. Gardner, J. Hilliard, M. A. Pfeiffer, and J. Stewart

1999 Excavations in the Shady Lake Recreation Area and Vicinity, 1992-1993, Ouachita National Forest. The Arkansas Archeologist 38:1-54.

Coleman, R. E., R. Graham, C. Hill, T. McKay, and B. Morphew 2000 Archeological Assessment for Compartments 95-97, Little Missouri Watershed, Caddo Ranger District, Ouachita National Forest, Montgomery County, Arkansas. Cultural Resources Report No. 187. Ouachita National Forest, Hot Springs.

Coleman, R. E., R. Graham, L. Graham, and B. Morphew

1995 Cultural Resources Survey for a Proposed Timber Harvest, Compartments 47, 48, and 49, Caddo Ranger District, Ouachita National Forest, Montgomery County, Arkansas. Ouachita Cultural Resources Report No. 142. USDA Forest Service, Ouachita National Forest, Hot Springs, Arkansas.

Coleman, R. E., R. Graham, B. Rowland, J. Fryar, E. Stovall, R. Anderson, and L. Graham 
1998 Archeological Assessment for Silver Watershed and Cultural Resources Survey for a Proposed Timber Harvest, Womble Ranger District, Ouachita National Forest, Montgomery County, Arkansas. Ouachita Cultural Resources Report No. 172. Ouachita National Forest, Hot Springs.

Coleman, R. E., S. Jones, J. Fryar, and A. C. Wallace

2006 Archeological Survey at the Southern Escarpment Inventory in Compartment 122, Caddo Ranger District, Ouachita National Forest, Pike County, Arkansas. Ouachita Cultural Resources Report No. 255. USDA Forest Service, Ouachita National Forest, Hot Springs, Arkansas.

Coleman, R. E., R. McGrath, J. Hill, F. Woodral, K. Knight, and T. Williamson 1999 Archeological Assessment for Freedom Ecosystem Management Unit Cold Springs Ranger District, Ouachita National Forest, Scott County, Arkansas. Ouachita National Forest, Hot Springs.

Collier, M. R.

1984 A Settlement Pattern of the War Eagle Creek Valley, Madison County, Arkansas. Master's thesis, Department of Anthropology, University of Arkansas, Fayetteville.

Colquitt, W. T. and C. H. Webb

1940 Dental Diseases in an Aboriginal Group. Tri-State Medical Journal 12(4):2414-2417.

Commonwealth Associates, Inc.

1981 Cultural Resources Survey of the Red River Waterway from Shreveport to the Mississippi River. Report submitted to the U.S. Army Corps of Engineers, New Orleans by Commonwealth Associates, Inc., Jackson, Michigan.

Cooper, J. H. and E. S. Cooper

2005 Archaeological Investigations of 291 Acres at Mission Tejas State Park, Houston County, Texas. Report of Investigations No. 2004-06. CDimensions, Plano.

Cooper, J. H. and C. S. Spears

1996 A Cultural Resource Assessment of the U.S. 71 Relocation Project Between DeQueen and Interstate 40 in Sevier, Folk, Scott, Sebastian, and Crawford Counties, Arkansas. Project Report 76. Spears Professional Environmental and Archeological Research Service, Inc., West Fork, Arkansas.

Cooper, J. H., E. Salo, J. Messier, and S. M. Hunt 
2003 Phase I Cultural Resources Survey of the Dillard and Bois d'Arc Revetment Items, Miller, Lafayette, and Hempstead Counties, Arkansas. Miscellaneous Report of Investigations No. 226. Geo-Marine, Inc., Plano.

Cooper, J. H., E. Salo, J. M. Enright, D. Shanabrook, E. Burson, and S. M. Hunt 2003 Cultural Resources and Remote Sensing Investigations for Red River Navigation Feasibility Study. Miscellaneous Report of Investigations No. 235. Geo-Marine, Inc., Plano.

Corbin, J. E.

1983 The Adolphus Sterne Home: Preliminary Archaeological Investigations of a Mid-Nineteenth Century Plantation in Nacogdoches County, Texas. Papers in Anthropology No. 4. Stephen F. Austin State University, Nacogdoches.

1984 An Archaeological Assessment of a Portion of the Washington Square Mound Site (41NA49), Nacogdoches County, Texas. Archaeological Investigations No. 1. Stephen F. Austin State University, Nacogdoches.

1985 A Short History of the Washington Square Mound Site: or How We Know Some of What We Know Without Actually Digging. Texas Archeology 29(4):7-8.

1985 Archaeological Survey of a Portion of Lindsay Park, Smith County, Texas. James E. Corbin, Nacogdoches.

1989 The Woodland/Caddo Transition in the Southern Caddo Area. In Festschrift in Honor of Jack Hughes, edited by D. Roper, pp. 117-124. Special Publication No. 5. Panhandle Archeological Society, Amarillo.

1992 Archaeological Survey of the Proposed Amoco Production Company Pipeline, Harrison County, Texas. James E. Corbin, Nacogdoches.

1994 Archaeological Survey of a Portion of a Proposed Trail Location and Parking Lot in the Stephen F. Austin Experimental Forest, Angelina National Forest, Nacogdoches County, Texas. James E. Corbin, Nacogdoches.

1996 Spanish-Caddoan Interaction in Eastern Texas. Journal of Northeast Texas Archaeology 7:20-26.

1997 Snake Woman. La Tinaja 10(4):11

1998 Reflections on the Early Ceramic Period and the Terminal Archaic in South Central East Texas. Journal of Northeast Texas Archaeology 11:108-116. 
2007 Cultural Diversity in the Southern Caddo Region. Journal of Northeast Texas Archaeology 26:11-23.

Corbin, J. E. and J. P. Hart

1998 The Washington Square Mound Site: A Middle Caddo Mound Complex in South Central East Texas. Bulletin of the Texas Archeological Society 69:47-78.

Corbin, J. E. and D. C. Kisling

1983 The Adolphus Sterne Home: Preliminary Archaeological Investigations of a Mid-Nineteenth Century Plantation in Nacogdoches County, Texas. Papers in Anthropology No. 4. Stephen F. Austin State University, Nacogdoches.

Corbin, J. E., T. C. Alex, and A. Kalina

1980 Mission Dolores de los Ais. Papers in Anthropology No. 2. Stephen F. Austin State University, Nacogdoches.

Corbin, J. E., D. C. Kisling, S. Oakes, and J. P. Hart

1984 Archaeological Investigations of the Washington Square Mound Site (41NA49), Nacogdoches County, Texas. Papers in Anthropology No. 5. Stephen F. Austin State University, Nacogdoches.

Corbin, J. E., J. M. Studer, and L. Numi

1978 The Chayah Site. Papers in Anthropology No. 1. Stephen F. Austin State University, Nacogdoches.

Corbin, J. E., H. A. Brown, M. G. Canavan, and S. Toups

1990 Mission Dolores de los Ais (41SA25): San Augustine County, Texas, Archeological Investigations. Stephen F. Austin State University, Nacogdoches

Corbin, J. E., J. M. Williams, V. J. Galan, and R. St. John

1994 Cultural Resource Survey of Fort Boggy State Park, Leon County, Texas. Public Lands Division, Cultural Resources Program, Texas Parks and Wildlife Department, Austin.

Cox, J. E.

2014 A Spiro Copper Hand-and-Eye Motif and Its Interpretation. Central States Archaeological Journal 61(4):264-270.

2014 The Williams Spiro Turtle Bowl. Central States Archaeological Journal 61(4):365-367.

Crane, C. J. 
1982 Plant Utilization at Spoonbill, an Early Caddo Site in Northeast Texas. Midcontinental Journal of Archaeology 7(1):81-97.

Crane, H. R. and J. B. Griffin

1960 University of Michigan Radiocarbon Dates V. American Journal of Science Radiocarbon Supplement 2:31-48.

Cranford, D.

2007 The Norman (34WG2) and Harlan (34CK6) Sites: Political Dynamics of Closely Spaced Mississippian Polities in Eastern Oklahoma. Master's thesis, Department of Anthropology, University of Oklahoma, Norman.

2007 The Norman (34WG2) and Harlan (34CK6) Sites: Political Dynamics of Closely Spaced Mississippian Polities in Eastern Oklahoma. Lulu Press.

Creel, D. G.

1979 Archeological Investigations at the George C. Davis Site, Cherokee County, Texas, Summer 1978. Texas Antiquities Permit Series No. 1. Texas A\&M University, College Station.

1991 Bison Hides in Late Prehistoric Exchange in the Southern Plains. American Antiquity 56(1):40-49.

1996 Hatchel-Mitchell Site. In The New Handbook of Texas, Vol. 3, edited by R. Tyler, pp. 504-505. Texas State Historical Association, Austin.

2002 Caddoan Mounds State Historic Site, Cherokee County, Texas. In Texas Parks and Wildlife Department 2001 Annual Report to the Texas Historical Commission, pp. 1-10. Cultural Resources Program, Texas Parks and Wildlife Department, Austin.

Creel, D., J. R. Ferguson, and N. A. Kenmotsu

2012 A Compositional Analysis of Central Texas Hunter-Gatherer Ceramics and its Implications for Mobility, Ethnic Group Territory, and Interaction. Prewitt and Associates, Inc., Austin.

2013 A Compositional Analysis of Central Texas Hunter-Gatherer Ceramics and its Implications for Mobility, Ethnic Group Territory, and Interaction.

Bulletin of the Texas Archeological Society 84:29-83.

Creel, D., D. Hudler, and S. Wilson

2002 Remote sensing detects more structures at Caddoan Mounds. Newsletter of the Friends of the Texas Archeological Research Laboratory, July 2002, pp. 2-6.

Creel, D. G., D. Hudler, S. M. Wilson, T. C. Schultz, and C. P. Walker 
2005 A Magnetometer Survey of Caddoan Mounds State Historic Site. Technical Report 51. Texas Archeological Research Laboratory, The University of Texas at Austin.

2008 Geophysical Survey of the Mound B Area at the George C. Davis Site. Bulletin of the Texas Archaeological Society 79:177-190.

Crook, W. W., Jr. and R. K. Harris

1961 A Type of Pottery Site in North Central Texas That May be Pre-Gibson. Bulletin of the Texas Archeological Society 31:101-108.

Crook, W. W., III

1987380 Bridge Site (41COL66): A Small Wylie Focus Village in Collin County, Texas. Texas Archeology 31(4):7-8.

1989 The Enloe Site (41COL65): A Diagnostic Wylie Occupation in Collin County, Texas. Texas Archeology 33(1):10-11.

2007 The Branch Site (41COL9): A Large Diagnostic Late Prehistoric Occupation in Collin County, Texas. The Record 55(2):30-44. Dallas Archeological Society, Dallas.

2007 The Mantooth Site (41COL167): A Mid-Size Late Prehistoric Occupation in Collin County, Texas. The Record 55(2):45-57. Dallas Archeological Society, Dallas.

2007 An Unusual Ceramic Vessel From The Sister Grove Creek Site, CollinCounty, Texas. The Record 55(2):69-73. Dallas Archeological Society, Dallas.

2011 The Gilkey Hill Site (41KF42/41DL406): A Large Late Prehistoric Occupation in Dallas County, Texas. Archeological Journal of the Texas Prairie Savannah 1(1):9-17.

2011 The Upper Farmersville South Site (41COL44): A Small Late Prehistoric Occupation in Collin County, Texas. Archeological Journal of the Texas Prairie Savannah 1(1):29-36.

2013 Mouth of Pilot Site (41COL4): Mid-Size Late Prehistoric Site in Collin County, Texas. Archeological Journal of the Texas Prairie Savannah 3(1):1-6.

2013 The Thompson Lake Site (41COL3): A Late Prehistoric Occupation in Collin County, Texas. Archeological Journal of the Texas Prairie Savannah 3(1):27-35. 
2014 A Small Killough Pinched Vessel from the Upper Farmersville Site (41COL34), Collin County, Texas. Archeological Journal of the Texas Prairie Savannah 4:44-50.

2014 A Maydelle Incised Jar from the Lower Rockwall Site (41RW1), Rockwall County, Texas. Archeological Journal of the Texas Prairie Savannah 4:5056.

2014 Unique Trade Items and/or "Pick-up" Artifacts from Sites along the East Fork. Archeological Journal of the Texas Prairie Savannah 4:61-67.

2014 A Ceramic Spindle Whorl from the Sister Grove Creek Site (41COL36), Collin County, Texas. The Journal, Houston Archeological Society 133:1721.

Crook, W. W., III and M. D. Hughston

2009 Upper Farmersville Site (41COL34): A Large Diagnostic Late Prehistoric Occupation in Collin County, Texas. The Record 56(1):25-46.

2011 Three Mid-Size Late Prehistoric Sites from Rockwall County, Texas. Archeological Journal of the Texas Prairie Savannah 1(1):37-46.

2015 Ceramic Types from Late Prehistoric Sites along the East Fork of the Trinity River. Journal of Texas Archeology and History 2:17-44.

2015 The Late Prehistoric of the East Fork: A Redefinition of Cultural Concepts Along the East Fork of the Trinity River, North Central Texas. CreateSpace Publishing, LLC, Charleston, South Carolina.

2016 The Late Prehistoric of the East Fork of the Trinity River. CRHR Research Reports, Volume 2, Article 1:116.http://scholarworks.sfasu.edu/crhr_research_reports/vol2/iss1/1.

Crook, W. W., III and T. K. Perttula

2008 A Foster-Trailed Incised Vessel from the Sister Grove Creek Site (41COL36), Collin County, Texas. Caddo Archeology Journal 18:22-25.

Cruse, J. B.

1995 Archaeology at the Oak Hill Village: A Caddoan Settlement in Rusk County. Heritage 13(1):10-14. Texas Historical Foundation, Austin.

Cruse, J. B. and T. K. Perttula

1996 The Caddoan Oak Hill Village. Caddoan Archeology Newsletter 6(4):2325.

Cutler, $\mathrm{H}$. 
1959 Plant Material from Six Oklahoma Sites. Oklahoma Anthropological Society Newsletter 8(3):4-7.

Cutler, H. C. and L. W. Blake

1973 Plants from Archeological Sites East of the Rockies. Missouri Botanical Gardens, St. Louis.

Dailey, L. B.

1958 Pre-Historic Mounds in Arkansas: An Archaeological Excavation of a PreHistoric Caddo Burial Mound on Mink Branch Near the Little Missouri River Located in Clark County, Arkansas. MS on file, Arkansas Archeological Survey, Fayetteville.

1958 Pre-Historic Mounds in Arkansas: A Preliminary Report on Village and Camp Sites Near the Hineman Mounds, in Ouachita County, Arkansas. MS on file, Arkansas Archeological Survey, Fayetteville.

Davies, C., C. Brown, T. R. Fenn, M. Williams, J. A. Green, Jr., and D. D. Davis 1997 Phase III Data Recovery Excavations at Grand Bayou Reservoir, Sites 16RR64 and 16RR292, Red River Parish, Louisiana. Four Volumes. Prepared by R. Christopher Goodwin and Associates, Inc. for the Louisiana Department of Transportation and Development. Report on file at the Louisiana Division of Archaeology, Department of Culture, Recreation, and Tourism, Baton Rouge.

Davis, C.

2014 Archaeological Investigations at the Texas A\&M University-Commerce Farm, Hunt County, Texas. Cultural Resources Report 2014-08. AR Consultants, Inc., Richardson.

2016 Archaeological Investigations at the Witcher Property within the Lower Bois d'Arc Creek Reservoir, Fannin County, Texas. AR Consultants, Inc., Richardson.

Davis, C. S., A. M. Rutherford, D. Anglin, and S. A. Skinner

2016 Archaeological Investigations of the Proposed Lower Bois d'Arc Creek Reservoir Mitigation Property, Riverby Ranch, Fannin and Lamar Counties, Texas. AR Consultants, Inc., Richardson.

Davis, C. S., S. A. Skinner, D. Anglin, and K. M. Pocklington 2013 Archaeological Survey of the Proposed Lower Bois d'Arc Creek Pipeline Project, Fannin County, Texas. AR Consultants, Dallas.

Davis, C. S., S. A. Skinner, and M. A. Hall 
2014 Archaeological Survey of the Proposed Lower Bois d'Arc Creek Reservoir, Fannin County, Texas. Cultural Resources Report 2014-60. AR Consultants, Dallas.

Davis, E. M.

1958 The Whelan Site, A Late Caddoan Component in the Ferrell's Bridge Reservoir, Northeastern Texas. Division of Research in Anthropology, The University of Texas at Austin.

1961 Proceedings of the Fourth Conference on Caddoan Archeology. Bulletin of the Texas Archeological Society 30:1-33.

1961 Proceedings of the Fifth Conference on Caddoan Archeology. Bulletin of the Texas Archeological Society 31:77-143.

1961 The Caddoan Area: An Introduction to the Symposium. Bulletin of the Texas Archeological Society 31:3-10.

1961 Symposium: Relationships Between the Caddoan Area and Neighboring Areas. Bulletin of the Texas Archeological Society 31:27-37.

1962 Archaeological Salvage Investigations of the Harling Mound in Fannin County, Texas. American Philosophical Society Yearbook 1961:487-489.

1962 The Harling Site (41FN1), Fannin County, Texas. Plains Anthropologist 7(16):86.

1970 Archaeological and Historical Assessment of the Red River Basin in Texas. In Archeological and Historical Resources of the Red River Basin: Louisiana, Texas, Oklahoma, and Arkansas, edited by H. A. Davis, pp. 2765. Research Series No. 1. Arkansas Archeological Survey, Fayetteville.

1996 Harling Site. In The New Handbook of Texas, Vol. 3, edited by R. Tyler, pp. 462-463. Texas State Historical Association, Austin.

1996 Whelan Site. In The New Handbook of Texas, Vol. 6, edited by R. Tyler, p. 921. Texas State Historical Association, Austin.

Davis, E. M. and J. Gipson

1960 The Dalton Site: A Late Caddoan Mound Site in the Ferrell's Bridge Reservoir Area, Northeastern Texas. Division of Research in Anthropology, The University of Texas at Austin.

Davis, E. M. and B. Golden 
1960 The Ben McKinney Site, A Titus Focus Site in the Ferrell's Bridge Reservoir, Northeastern Texas. Division of Research in Anthropology, The University of Texas at Austin.

Davis, E. M., W. A. Davis, J. R. Gipson, and B. Golden

2010 Archeological Investigations at Lake O' The Pines, Marion and Upshur Counties, Texas, 1957-1959. Archival Series 4. Texas Archeological Research Laboratory, The University of Texas at Austin.

Davis, H. A.

1962 The Destruction of Mound C at the Crenshaw Site. Plains Anthropologist 7(16):88.

1965 A History of Prehistory in the Mid-Ouachita River Valley. The Record 6:93100. Garland County Historical Society Yearbook, Hot Springs.

1967 The Puzzle of Point Remove. Field Notes (Newsletter of the Arkansas Archeological Society) 33:2-7.

1978 An Archeological Inventory of Pulaski and Saline Counties. The Arkansas Archeologist 19:36-43.

1981 From the Den of Antiquity. Field Notes (Newsletter of the Arkansas Archeological Society) 178:9-10.

1981 An Unusual Ceremony. Field Notes (Newsletter of the Arkansas Archeological Society) 182:9.

Davis, H. A. (editor)

1966 Caddoan Area Field Reports, 1962-1964 Seasons. University of Arkansas Museum, Fayetteville.

1970 Archeological and Historical Resources of the Red River Basin: Louisiana, Texas, Oklahoma, and Arkansas. Research Series No. 1. Arkansas Archeological Survey, Fayetteville.

1982 A State Plan for the Conservation of Archeological Resources in Arkansas. Research Series No. 21. Arkansas Archeological Survey, Fayetteville.

Davis, H. A. and E. M. Davis

2009 An Account of the Birth and Growth of Caddo Archeology, as Seen by Review of 50 Caddo Conferences, 1946-2008. Caddo Archeology Journal 19:3-72.

Davis, H. A., D. G. Wyckoff, and M. A. Holmes (editors) 
1971 Proceedings of the Seventh Caddo Conference. Occasional Publication No. 1. Oklahoma Archeological Survey, Norman.

1971 Proceedings of the Eighth Caddo Conference. Occasional Publication No. 2. Oklahoma Archeological Survey, Norman.

Davis, J., M. B. Reed, L. E. Raymer, and C. Hanson

1996 An Archaeological Survey of 2,318 Acres in the Mena, Poteau, and Tiak Districts of the West Zone of Ouachita National Forest, Polk and Scott Counties, Arkansas, and McCurtain County, Oklahoma. Technical Report No. 294. New South Associates, Stone Mountain, Georgia.

Davis, M. W., A. C. Earls, and M. S. F. Tomka

19921987 Archeological Excavations at the George C. Davis Site (41CE19), Caddoan Mounds State Historical Park, Cherokee County, Texas.

Technical Report No. 1. Texas Parks and Wildlife Department, Austin.

Davis, W. A.

1961 The Isadore Segal Site at Ferrell's Bridge Reservoir, Texas. Texas Archeological Salvage Project, The University of Texas at Austin.

Davis, W. A. and H. R. Horn

1964 The Zavonian Springs Site: An Archaic-Neo-American Site in McGee Bend Reservoir, San Augustine County, Texas. Bulletin of the Texas Archeological Society 35:113-150.

Day, G., et al.

2010 Archaeological Site Detection Survey of Selected Parcels Bordering Lake Hudson in Mayes County, Oklahoma. Report prepared for the Grand River Dam Authority, Langley, Oklahoma by AMEC Earth \& Environmental.

DeBoer, T., D. St. Germain, and T. Gannon

1997 An Archeological Survey of 5,126 Acres in the Mena and Poteau Ranger Districts of the Ouachita National Forest, Scott and Polk Counties, Arkansas. Project Report 121. Spears Professional Environmental and Archeological Research Service, Inc., West Fork, Arkansas.

Dellinger, S. C.

n.d. Report Summarizing Adair Site Finds. Manuscript on file, University of Arkansas Museum, Fayetteville.

Dellinger, S. C. and S. D. Dickinson

1939 Excavation of the Adair Site, Garland County, Arkansas. WPA Project No. 665-63-3-170. Manuscript on file, University of Arkansas Museum, Fayetteville. 
1940 Excavation of the Means Place, a Caddo-Coles Creek Site in Hot Springs County, Arkansas. Manuscript on file, University of Arkansas Museum, Fayetteville.

1942 Pottery from the Ozark Bluff Shelters. American Antiquity 7(3):276-311.

DeMaio, J.

2013 The Adair Site: Ouachita River Valley Relations Through Ceramic Analysis. Master's thesis, Department of Anthropology, University of Arkansas, Fayetteville.

Dering, J. P.

2001 Botanical Materials from the Griffin Mound (41UR142) and Underwood (41CP230) Sites. Journal of Northeast Texas Archaeology 14:7-12.

2004 Archaeobotanical Evidence for Agriculture and Wild Plant Use at 41RK214. In The Oak Hill Village Site (41RK214), Rusk County, Texas, by R. Rogers and T. K. Perttula, pp. 329-336. Document No. 030083. PBS\&J, Austin.

Derrick, S. M.

1997 A Study in Frustration: Analysis of Human Remains Recovered from the Coker Mound Site (41CS1). Journal of Northeast Texas Archaeology 9:2129.

Derrick, S. M. and D. Wilson

1997 Cranial Modeling as an Ethnic Marker among the Prehistoric Caddo. Bulletin of the Texas Archeological Society 68:139-146.

2001 The Effects of Epidemic Disease on Caddo Demographic Structure. Bulletin of the Texas Archeological Society 72:91-103.

Derrick, S. M., G. R. Colby, and D. G. Steele

2008 Analysis of Human Remains from the Arnold Roitsch Site (41RR16). In Collected Papers from Past Texas Archeological Society Field Schools, edited by T. K. Perttula, pp. 413-432. Special Publication No. 5. Texas Archeological Society, San Antonio.

Descantes, C., D. Creel, R. J. Speakman, S. Wilson, and M. D. Glascock 2005 Instrumental Neutron Activation Analysis of Pottery from the George C. Davis Site, Texas. North American Archaeologist 25(2):121-138.

Descantes, C., R. J. Speakman, and M. D. Glascock 2007 Instrumental Neutron Activation Analysis of Pottery from Four Caddoan Sites at the Barksdale AFB, Louisiana. In Barksdale Air Force Base, Louisiana: National Register Evaluative Testing at Prehistoric Sites 
16BO450, 16BO458, and 16BO473, Barksdale Air Force Base, Bossier Parish, Louisiana, by C. Lintz, F. Largent, T. Perttula, V. Dongarra, M. Prior, and M. Huhnke, pp. G-1 to G-17. Report of Investigations No. 37. United States Air Force Headquarters Air Combat Command Series.

2011 Instrumental Neutron Activation Analysis. In Barksdale Air Force Base, Louisiana: National Register Evaluative Testing at Sites 16BO453, 16BO454, 16BO476, 16BO477, and 16BO531. Barksdale Air Force Base, Bossier Parish, Louisiana, by M. M. Green, C. Lintz, M. D. Freeman, A. Burkholder, and T. K. Perttula, pp. E-1 to E-3. Report of Investigations No. 57. United States Air Force Headquarters Air Combat Command Series.

Dickens, W. A. and J. E. Widerhold

2004 Some Notes on Bison, the Texas Post Oak Savanna, and the Late Prehistoric Period of Texas. Bulletin of the Texas Archeological Society 74:31-54.

Dickerson, K. E., K. L. Shingleton, Jr., K. Muller, and D. O. Henry 1991 Tulsa/Tulsa North Triangle: An Archaeological Survey of Northern Tulsa and Western Rogers Counties, Oklahoma. Contributions in Archaeology No. 18. Department of Anthropology, University of Tulsa, Tulsa, Oklahoma.

Dickinson, S. D.

1936 Ceramic Relationships of the Pre-Caddo Pottery from the Crenshaw Site. Bulletin of the Texas Archeological and Paleontological Society 8:56-69.

1941 Certain Vessels from the Clements Place, a Historic Caddo Site. Bulletin of the Texas Archeological and Paleontological Society 13:117-134.

1943 Notes on the Decoration and Form of Arkansas Caddo Pottery. Bulletin of the Texas Archeological and Paleontological Society 15:9-29.

Dickinson, S. D. and S. C. Dellinger

1940 A Survey of the Historic Earthenware of the Lower Arkansas Valley. Bulletin of the Texas Archeological Society 12:76-96.

Dickinson, S. D. and H. J. Lemley

1939 Evidences of the Marksville and Coles Creek Complexes at the Kirkham Place, Clark County, Arkansas. Bulletin of the Texas Archeological and Paleontological Society 11:139-189.

Dickson, D. B.

1979 Cultural Resources Survey of Seven Project Areas on Red River between Boyce and Shreveport, Bossier, Caddo, Winn, Natchitoches, and Grant Parishes, Louisiana. Manuscript on file, Division of Archaeology and 
Historic Preservation, Department of Culture, Recreation and Tourism, Baton Rouge.

Dickson, D. R.

1960 The Neosho Focus. Central States Archaeological Journal 7(1):12-17.

1961 Preliminary Excavations at the Albertson Site \#1: A Northwest Arkansas Bluff Shelter. Plains Anthropologist 6 (12, Pt. 2):117-125.

1991 The Albertson Site: A Deeply and Clearly Stratified Ozark Bluff Shelter. Research Series No. 41. Arkansas Archeological Survey, Fayetteville.

2011 The Cloud-Williams Site. The Missouri Archaeologist 72:177-207.

Dinnel, K.

1979 An Archeological Survey of the Proposed Delta Specialty Landfill Project in Hempstead County, Arkansas. Project Report No. 325. Arkansas Archeological Survey, Fayetteville.

Dixon, B., S. Kotter, and R. Taylor

1997 Data Recovery Excavations at the Mockingbird Site (41TT550): The Archaic and Early Caddo Components. Document No. 970735. Espey, Huston \& Associates, Inc., Austin.

Dixon, B., S. Kotter, E. Skokan, M. Nash, R. Rogers, and E. Barnhart

1995 Archaeological Testing of Site 41TT672 and Geomorphological Exploration of Tankersley and Dragoo Creek Drainages, Titus County, Texas. Document No. 950565. Espey, Huston \& Associates, Inc., Austin.

Dixon, B., M. K. Rusell, M. Beherec, and E. Grubb

2005 A Cultural Resources Survey for the Pittsburg to Winnsboro 138-kV Transmission Line, Camp, Franklin, and Wood Counties, Texas. PBS\&J, Austin.

Dixon, B., C. Smith, S. Loftus, J. Shipp, L. Ellis, R. Shortes, B. Harris, R. Rogers, C. Wallace, and M. Nash

2009 Intensive Cultural Resources Survey of the Proposed South Henderson Deposit First 5-Year Area and Ancillary Properties, Rusk County, Texas. Document No. 080138. PBS\&J, Austin.

Dockall, H. D.

1994 Human Skeletal Remains from the Tyson Site (41SY92). Journal of Northeast Texas Archaeology 3:37-50.

Dockall, J. E. and R. C. Fields 
2006 Reconnaissance Survey to Assess the Impacts on Archeological Resources of the Proposed Conservation Pool Level Raise at Wright Patman Lake, Bowie and Cass Counties, Texas. Reports of Investigations No. 146. Prewitt and Associates, Inc., Austin.

2011 National Register Testing of Three Sites in the Sabine Mine's South Hallsville No. 1 Mine-Rusk Permit, Rusk County, Texas. Report of Investigations No. 162. Prewitt and Associates, Inc., Austin.

2011 Archeological Testing in the Vicinity of 41TT36, Titus County, Texas. Letter Report No. 836. Prewitt and Associates, Inc., Austin.

Dockall, J. E., A. E. Dase, and R. C. Fields

2014 Archeological and Historical Resources Survey of 4,392 Acres in the South Hallsville No. 1 Mine-Rusk Permit, Area W, Rusk County, Texas. Reports of Investigations No. 170. Prewitt and Associates, Inc., Austin.

Dockall, J. E., R. C. Fields, and A. E. Dase

2015 Archeological and Historical Resources Surveys of 380 Acres in the Sabine Mine's N Area, Harrison County, Texas. Reports of Investigations No. 177. Prewitt and Associates, Inc., Austin.

Dockall, J., S. Katauskas, and R. Fields

2008 National Register Testing of Four Sites in the Sabine Mine's Area M, Harrison County, Texas. Reports of Investigations No. 157. Prewitt and Associates, Inc., Austin.

Dockall, J. E., R. C. Fields, S. L. Katauskas, A. E. Dase, and K. W. Kibler 2010 Archeological and Historic Resources Surveys of 6,925 Acres in the East Part of the Sabine Mine's South Hallsville No. 1 Mine-Rusk Permit, Panola and Rusk Counties, Texas. Report of Investigations No. 158. Prewitt and Associates, Inc., Austin.

Doehner, K. and R. E. Larson

1978 Archaeological Research at Cooper Lake, Northeast Texas, 1974-75. Research Report No. 108. Archaeology Research Program, Southern Methodist University, Dallas.

Doehner, K., D. Peter, and S. A. Skinner

1978 Evaluation of the Archaeology at the Proposed Cooper Lake. Research Report No. 114. Archaeology Research Program, Southern Methodist University, Dallas.

Doran, G.

1974 The Long Bones of the Texas Indians. Master's thesis, Department of Anthropology, The University of Texas at Austin. 
Dornheim, S.

2011 TxDOT_Roadside Chat... Texas Archeology 55(1):18-21.

Dorman, C.

1934 Caddo Pottery. Art and Archaeology 35(2):59-68.

Dow, L. A. B.

1987 The Genetic Affinities and Adaptive Success of Three Groups of Late Prehistoric Amerindians from Texas. Master's thesis, Department of Anthropology, The University of Texas at Austin.

Dowd, E. L.

2008 Identifying Variation: A Stylistic Analysis of Four Caddo Pottery Assemblages from Southeastern Oklahoma. Master's thesis, Department of Anthropology, University of Oklahoma, Norman.

2010 New Approaches to Old Collections: Identifying Stylistic Variation Among Caddo Pottery from Southeastern Oklahoma. The Arkansas Archeologist 49:17-31.

2011 Identifying Variation: A Stylistic Analysis of Four Caddo Pottery Assemblages from Southeastern Oklahoma. Memoir 15. Oklahoma Anthropological Society, Norman.

2011 Mountain Fork Archaeology: A Preliminary Report on the Ramos Creek Site (34MC1030). Caddo Archeology Journal 21:29-41.

2011 Sourcing Red River Jasper: An Archaeological and Geological Investigation of a Gravel Chert in the Red River Drainage. Caddo Archeology Journal 21:89-106.

2011 Amphibian and Reptilian Imagery in Caddo Art. Southeastern Archaeology 30(1):79-95.

2012 Alternative Conceptions of Complexity: Sociopolitical Dynamics of the Mountain Fork Caddo. Ph.D. dissertation, Department of Anthropology, University of Oklahoma, Norman.

Dowd, E. and A. Regnier

2014 Archaeological Investigations at the Ramos Creek Site (34MC1030), McCurtain County, Oklahoma. Final Report submitted to U.S. Forest Service, Ouachita National Forest. Report on file at the Oklahoma Archeological Survey, Sam Noble Museum of natural History, University of Oklahoma, Norman. 
Dowd, E., G. Morgan, and B. Schriever

2009 Electron Microprobe Analysis of Five Caddo Pottery Sherds from the Tuinier Farm Site. Journal of Northeast Texas Archaeology 30:40-48.

Dozier, T.

2004 Proposed Wildlife Ponds in Compartments 607, 647, \& 648, Jessieville Ranger District, Garland County. Ouachita Cultural Resources Report No. 246. Ouachita National Forest, Hot Springs.

2005 An Archeological Survey for a Proposed Timber Sale Project and Associated Actions, Achmun Creek Watershed, Fourche Ranger Districts, Yell County, Arkansas. Ouachita Cultural Resources Report No. 254. Ouachita National Forest, Hot Springs.

Drake, D.

2000 Archaeological Survey for the SRA Utility Pipelines Project, Shelby, Panola, and Rusk Counties, Texas. Cultural Resources Report 99-68. SWCA, Inc., Austin.

Drass, R. R.

1981 An Archeological Survey of the Bayou Manard Watershed, Northeastern Oklahoma. Archeological Resource Survey Report No. 10. Oklahoma Archeological Survey, University of Oklahoma, Norman.

1981 An Unusual Pot from Haskell County, Oklahoma. Oklahoma Anthropological Society Newsletter 30(8):3-5.

1985 Archeological Resources in the Bird Creek Basin, Rogers, Tulsa and Osage Counties, Oklahoma. Archeological Resource Survey Report No. 21. Oklahoma Archeological Survey, University of Oklahoma, Norman.

Drass, R. R. and D. Peterson

1981 An Engraved Shell Gorget from Grady County, Oklahoma. Bulletin of the Oklahoma Anthropological Society 30:67-79.

Driggers, W. G.

1985 A Report on the Analysis of the Ceramic Vessel Materials from the Benson's Crossing Site (41TT110), Titus County, Texas. Master's thesis, Department of Anthropology, The University of Texas at Austin.

'Driskell, B. N. and M. A. Howard (editors)

1988 Inventory, Assessment, and National Register Testing of Selected Tracts at the Louisiana Army Ammunition Plant, Minden, Louisiana. Reports of Investigations No. 60. Prewitt and Associates, Inc., Austin.

Driver, S. 
2003 The Caddo People. The Potters Shop 16(2):12-13.

Drooker, P. B.

2017 The Fabric of Power: Textiles in Mississippian Politics and Ritual. In Forging Southeastern Identities: Social Archaeology, Ethnohistory, and Folklore of the Mississippian to Early Historic South, edited by G. A. Waselkov and M. T. Smith, pp. 15-40. University of Alabama Press, Tuscaloosa.

Dryden, M. D.

1999 Liberty Salvage 1999. Forest Service Project 99-10-05-09. Ozark-St. Francis National Forests, Russellville.

1999 Mountain Fork Range and Wildlife Project. Forest Service Project 99-1005-13. Ozark-St. Francis National Forests, Russellville.

1999 Shady Grove Environmental Analysis Area. Forest Service Project 98-1006-04. Ozark-St. Francis National Forests, Russellville.

1999 Wedington Prescribed Burns. Forest Service Project 99-10-05-01. OzarkSt. Francis National Forests, Russellville.

2000 North Tower Environmental Analysis Area (PIF). Forest Service Project 99-10-06-03. Ozark-St. Francis National Forests, Russellville.

Duffield, L. F.

1960 Appaisal of the Archeological Resources of Flat Creek Reservoir, Henderson County, Texas. Texas Archeological Salvage project, The University of Texas at Austin.

1961 The Limerick Site at Iron Bridge Reservoir, Rains County, Texas. Bulletin of the Texas Archeological Society 30:51-116.

1963 The Wolfshead Site: An Archaic-Neo-American Site in San Augustine County, Texas. Bulletin of the Texas Archeological Society 34:83-141.

1963 The Strawn Creek Site: A Mixed Archaic and Neo-American Site at Navarro Mills Reservoir, Navarro County, Texas. Texas Archeological Salvage Project, The University of Texas at Austin.

1964 Engraved Shells from the Craig Mound at Spiro, LeFlore County, Oklahoma. Memoir No. 1. Oklahoma Anthropological Society, Norman.

1969 The Vertebrate Faunal Remains from the School Land I and School Land II Sites, Delaware County, Oklahoma. Bulletin of the Oklahoma Anthropological Society 18:47-65. 
1973 The Oklahoma Craig Mound: Another Look at an Old Problem. Bulletin of the Oklahoma Anthropological Society 22:1-10.

1983 American World View and the Concept of Status. In Southeastern Natives and Their Pasts, edited by D. G. Wyckoff and J. L. Hofman, pp. 3-15. Studies in Oklahoma's Past No. 11. Oklahoma Archeological Survey, Norman.

2006 Looking Back at the Southern Plains: The Titanic and Other Stories. Plains Anthropologist 51(200):773-784.

Duffield, L. F. and E. B. Jelks

1961 The Pearson Site: A Historic Indian Site at Iron Bridge Reservoir, Rains County, Texas. Archaeology Series No. 4. Department of Anthropology, The University of Texas at Austin.

Duncan, K. C.

1977 Cultural Resources in the Tulsa, Oklahoma, Urban Study Area. Research Report No. 14. Archeological Research Associates, Tulsa, Oklahoma.

Duncan, K. C. and A. L. Cheek

1976 Excavations at At-90. Research Report No. 5. Archeological Research Associates, Tulsa, Oklahoma.

Durham, J. H.

1964 Notes on the 1961-62 Excavations at the Crenshaw Site, 3MI6, in Arkansas. Oklahoma Anthropological Society Newsletter 21(6):4-8.

1975 Additional Information on Burial Associations, Crenshaw Site, Mound C, Miller County, Arkansas. Bulletin of the Oklahoma Anthropological Society 24:155-160.

Durham, J. H. and M. K. Davis

1975 Report on the Burials Found at Crenshaw, Mound C, Miller County, Arkansas. Bulletin of the Oklahoma Anthropological Society 23:1-90.

Durham, J. H. and G. L. Kizzia

1964 A Deep Burial in Crenshaw Mound C, Miller County, Arkansas. Central States Archaeological Journal 11 (2):44-67.

Dye, D. H.

2009 War Paths, Peace Paths: An Archaeology of Cooperation and Conflict in Native Eastern North America. AltaMira Press, Lanham, Maryland.

Early, A. M. 
1974 Winter Archeology, the Hedges Site, 3HS60. Field Notes (Newsletter of the Arkansas Archeological Society) 116:3-5.

1978 Turquoise Beads from the Standridge Site, 3MN53. The Arkansas Archeologist 19:25-30.

1982 History of Archeological Work in the Eastern Ouachitas. In Fancy Hill: Archeological Studies in the Southern Ouachita Mountains, edited by A. M. Early and W. F. Limp, pp. 21-31. Research Series No. 16. Arkansas Archeological Survey, Fayetteville.

1982 Caddoan Settlement Systems in the Ouachita River Valley. In Arkansas Archeology in Review, edited by N. L. Trubowitz and M. D. Jeter, pp. 198232. Research Series No. 15. Arkansas Archeological Survey, Fayetteville.

1983 A Brief History of Archaeological Work in the Ouachita River Valley, Arkansas. Louisiana Archaeology 10:1-24.

1984 Survey and Testing of the Ross Site (3CL401). MS on file, Arkansas Archeological Survey, Arkadelphia.

1986 Dr. Thomas L. Hodges and His Contributions to Arkansas Archeology. The Arkansas Archeologist 23/24:1-11.

1988 Standridge: Caddoan Settlement in a Mountain Environment. Research Series No. 29. Arkansas Archeological Survey, Fayetteville.

1991 An Example of Rock Art from the Arkansas Ouachitas. Caddoan Archeology Newsletter 2(4):16-18.

1993 Finding the Middle Passage: The Spanish Journey from the Swamplands to Caddo Country. In The Hernando de Soto Expedition West of the Mississippi, 1541-1543, edited by G. A. Young and M. P. Hoffman, pp. 6877. University of Arkansas Press, Fayetteville.

1993 Hardman and Caddoan Saltmaking. In Caddoan Saltmakers in the Ouachita Valley: The Hardman Site, edited by A. M. Early, pp. 223-234. Research Series No. 43. Arkansas Archeological Survey, Fayetteville.

2000 First Encounters: The Caddo Indians. The Arkansas Amateur 39:5-6. Northwest Arkansas Archeological Society, Fayetteville.

2002 The East Phase. Field Notes (Newsletter of the Arkansas Archeological Society) 304: 4-8. 
2002 The Mid-Ouachita Phase. Field Notes (Newsletter of the Arkansas Archeological Society) 305: 10-13.

2002 The Social Hill Phase. Field Notes (Newsletter of the Arkansas Archeological Society) 306:10-13.

2002 The Deceiper Phase. Field Notes (Newsletter of the Arkansas Archeological Society) 307:8-11.

2004 Prehistory of the Western Interior after 500 B.C. In Handbook of North American Indians, Southeast, Volume 14, edited by R. B. Fogelson, pp. 560-573. Smithsonian Institution, Washington.

2008 The Caddo Indians. http://arkarcheology.uark.edu/indiansofarkansas/index.html?pageName=T he $\% 20$ Caddo $\% 20$ Indians

2010 Pre-European Exploration, Prehistory through 1540. The Encyclopedia of Arkansas History \& Culture, http://www.encyclopediaofarkansas.net/encyclopedia/entrydetail.aspx?search=1\&entrylD=395

2010 Salt Making. The Encyclopedia of Arkansas History \& Culture, http://encyclopediaofarkansas.net/encyclopedia/entrypdetail.aspx?entrylD $=567$.

2012 Form and Structure in Prehistoric Caddo Pottery Design. In The Archaeology of the Caddo, edited by T. K. Perttula and C. P. Walker, pp. 26-46. University of Nebraska Press, Lincoln.

2012 What All the King's Horses Has to Say to American Archaeologists. In All the King's Horses: Essays on the Impact of Looting and the Illicit Antiquities Trade on Our Knowledge of the Past, edited by P. K. Lazrus and A. W. Barker, pp. 127-132. The SAA Press, Washington, D.C.

2014 What Does 'Long Hat's Camp" Really Tell Us? A Consideration of the Meaning of Two Popular Photographs to Caddo Studies. Bulletin of the Texas Archeological Society 85:49-59.

Early, A. M. (editor)

1993 Caddoan Saltmakers in the Ouachita Valley: The Hardman Site. Research Series No. 43. Arkansas Archeological Survey, Fayetteville.

2000 Forest Farmsteads: A Millennium of Human Occupation at Winding Stair in the Ouachita Mountains. Research Series 57. Arkansas Archeological Survey, Fayetteville. 
Early, A. M. and W. F. Limp (editors)

1982 Fancy Hill: Archeological Studies in the Southern Ouachita Mountains. Research Series No. 16. Arkansas Archeological Survey, Fayetteville.

Early, A. M. and M. B. Trubitt

2003 The Caddo Indian Burial Ground (3MN386), Norman, Arkansas. Caddoan Archeology Journal 13(2):13-24.

Early, A. M., R. L., Guendling, R. E. Coleman, and M. L. Williams

1999 Archeological Investigations at the Winding Stair Locality, Montgomery County, Arkansas. Sponsored Research Program Project No. 941. Arkansas Archeological Survey, Fayetteville.

Education Department, Stovall Museum of Natural History

1983 Educational Aid for "The Spiro Mounds: Prehistoric Gateway, Present-Day Enigma." Stovall Museum of Natural History, University of Oklahoma, Norman.

Eighmy, J. L.

1969 The Fine Site: A Caddoan Site in Eastern Oklahoma. Archaeological Site Report No. 13. Oklahoma River Basin Survey Project, University of Oklahoma, Norman.

Ekland-Olson, C.

1981 Holly Fine Engraved- Some New Light on an Old Type. Master's thesis, Department of Anthropology, The University of Texas at Austin.

Elkins, A.

1959 The Skeletal Material from Ck-44, the Smullins Site. Bulletin of the Oklahoma Anthropological Society 7:55-61.

Ellis, L. W.

2013 Woodland Ceramics in East Texas and a Case Study of Mill Creek Culture Ceramics. Bulletin of the Texas Archeological Society 84:137-180.

Ellis, L. W., T. K. Perttula, and W. W. Crook, III

2015 Aboriginal Ceramics from the North Central Region of Texas. Bulletin of the Texas Archeological Society 86:159-191.

Ellis, L. W., R. Rogers, C. Wallace, D. Burden, A. Burden, A. Kalter, M. Smith, and C. Heiligenstein

2013 Data Recovery at the Hawkwind Site (41HS915), Harrison County, Texas. Document No. 120087. Atkins, and Report No. 138, Archeological Studies Program, Environmental Affairs Division, Texas Department of Transportation, Austin. 
El-Najjar, M.

2000 New Evidence for Human Treponematosis in Pre-Columbian North America. Journal of Paleopathology 12 (1): 17-24.

Emerson, T. E.

2015 The Earth Goddess Cult at Cahokia. In Medieval Mississippians: The Cahokian World, edited by T. R. Pauketat and S. M. Alt, pp. 54-62. School for Advanced Research Press, Santa Fe.

Emerson, T. E. and J. S. Girard

2004 Dating Gahagan and Its Implications for Understanding Cahokia-Caddo Interactions. Southeastern Archaeology 23(1):57-64.

Emerson, T. E. and R. E. Hughes

2000 Figurines, Flint-Clay Sourcing, the Ozark Highlands, and Cahokian Acquisition. American Antiquity 65(1):79-101.

Emerson, T. E., R. E. Hughes, M. R. Hymes, and S. R. Wisseman

2003 The Sourcing and Interpretation of Cahokia-Style Figurines in the TransMississippi South and Southeast. American Antiquity 68(2):287-313.

Engseth, M., K. Wittie, N. Heller, and W. P. Athens

2009 Phase I Cultural Resources Survey and Archaeological Inventory for the Black Lake HDD Project, Natchitoches, Louisiana. R. Christopher Goodwin and Associates, New Orleans.

Ennes, M. J., with contributions by M. B. Cliff

1997 Petrographic Analysis of Prehistoric Ceramics Recovered from Sites 41BW553 and 41TT670. In Cultural Resources Testing of Two Sites within the White Oak Creek Wildlife Management Area, Bowie and Titus Counties, Texas, by F. B. Largent, Jr., D. L. Beene, M. B. Cliff, and S. M. Hunt, pp. G-1 to G-22. White Oak Creek Mitigation Area Archeological Technical Series, Report of Investigations No. 6. Geo-Marine, Inc., Plano.

Ensor, H. B. and G. P. Smith

1999 Cultural Resource Work on 1,088 Acres, Pike County, on Lake Greeson, Arkansas. Cultural Resources Services, Inc., Memphis.

Erickson, E. C. and J. E. Corbin

1996 Archaeological Survey and Cultural Resource Assessment of Mission Tejas State Historical Park, Houston County, Texas. Public Lands Division, Cultural Resource Program, Texas Parks and Wildlife Department, Austin.

Espey, Huston \& Associates, Inc. 
1979 Cultural Resources Survey Phase II Plant Site/Cooling Pond Survey, Mine Area Predictive Model, South Hallsville Project. Document No. 78102. Espey, Huston \& Associates, Inc., Austin.

1980 A Survey and Assessment of the Cultural Resources -Oologah Lake Project. Espey, Huston and Associates, Inc., Austin.

1983 The Archaeological Investigations of the Louis Procello Site, 16DS212, De Soto Parish, Louisiana. Document No. 82360. Espey, Huston \& Associates, Inc., Austin.

Etchieson, M.

1981 A Shell Gorget from the Kirkham Site. The Arkansas Archeologist 22:1-3.

1995 Archeological Survey for a Proposed Land Exchange in Compartment 1634, Womble Ranger District, Ouachita National Forest, Montgomery County, Arkansas. Ouachita Cultural Resources Report No. 139. Ouachita National Forest, Hot Springs.

1997 Ouachita National Forest/Weyerhauser Company Land Exchange. Caddoan Archeology 8(2):27.

2000 Evaluation Testing at Site 34Mc517 within the Tiak Ranger District, McCurtain County, Oklahoma: A Field/Laboratory Manual. Ouachita Cultural Resources Report No. 192. Ouachita National Forest, Hot Springs.

2001 Evaluation Testing at Site 34Mc891 within the Tiak Ranger District, McCurtain County, Oklahoma: A Field/Laboratory Manual. Ouachita Cultural Resources Report No. 201. Ouachita National Forest, Hot Springs.

2003 Widening of Access Road to Cossatot Cabin. Ouachita National Forest, Hot Springs.

2003 Excavation at Site 34Mc576: An Historic Choctaw Farmstead within the Tiak Ranger District, McCurtain County, Oklahoma: A Field/Laboratory Manual. Ouachita Cultural Resources Report No. 222. Ouachita National Forest, Hot Springs.

2003 Archeological Investigations for the Weyerhaeuser-Forest Service Land Exchange, Oklahoma and Arkansas. Ouachita Cultural Resources Report No. 220. Ouachita National Forest, Hot Springs.

2006 The 2006 Spring Dig at the Red Slough Site, McCurtain County, Oklahoma. Oklahoma Archeology 54(4): 6-7. 
2006 Evaluation Testing at Site 34Mc850, McCurtain County, Oklahoma: A Field and Lab Manual. Ouachita Cultural Resources Report No. 267. Ouachita National Forest, Hot Springs.

Etchieson, M. (compiler)

2001 Quarterly Report \#1 for Archeological Investigations Conducted Under the Ice Damage Programmatic Agreement. Ouachita Cultural Resources Report No. 202. Ouachita National Forest, Hot Springs.

2003 Results of Archeological Surveys Resulting from the December 2000 Ice Storm, Caddo, Cold Springs, Fourche, Jessieville, Mena, Oden, Poteau and Womble Ranger Districts, Ouachita National Forest, Arkansas. Ouachita Cultural Resources Report No. 209. Ouachita National Forest, Hot Springs.

Etchieson, M. and L. Graham

1999 Evaluation Testing at Two Prehistoric Sites within the Tiak Ranger District, Ouachita National Forest, McCurtain County, Oklahoma: A

Field/Laboratory Manual. Ouachita Cultural Resources Report No. 179.

Ouachita National Forest, Hot Springs.

Etchieson, M. and M. B. Trubitt

2013 Plans for the $50^{\text {th }}$ Arkansas Archeological Society Training Program. Field Notes, Newsletter of the Arkansas Archeological Society 371:3-8.

2013 Taking it to the River: Arkansas Novaculite Quarrying and Archaic Period Tool Production. North American Archaeologist 34(4):387-407.

Eubanks, P. N.

2011 Summary of the Red River Saline Project, Summer 2011. Report submitted to the Gulf Coast Survey, Alabama Museum of Natural History, The University of Alabama, Tuscaloosa.

2012 Phase 1 Survey and Testing of the Proposed Location of the Drake's Salt Works (16WN30) Museum. Report for Mr. Jim L. Williams, Goldonna, Louisiana, by Gulf Coast Survey, Alabama Museum of Natural History, Tuscaloosa.

2013 An Archaeological Survey of Major Salt Domes in Northwestern Louisiana. Newsletter of the Louisiana Archaeological Society 41(1):15.

2013 Report of the 2012 Passport in Time Project at Drake's Salt Works (16WN30 \& 16NA11/17). Alabama Museum of Natural History, Gulf Coast Survey, Tuscaloosa. 
2014 The 2013 Excavations at Drake's Salt Works. Newsletter of the Louisiana Archaeological Society 41(3):12.

2014 The Timing and Distribution of Caddo Salt Production in Northwestern Louisiana. Southeastern Archaeology 33(1):108-122.

2014 The Spring 2014 Excavations at Drake's Salt Works. Newsletter of the Louisiana Archaeological Society 42(2):15.

2014 Report of the 2013 Excavations at the Little (16NA11) and Upper (16WN30) Salt Licks at Drake's Salt Works. Report submitted to the United States Forest Service, Kisatchie National Forest Southern Research Station, Alexandria, Louisiana.

2014 Summary of the Red River Saline Project, Spring 2014. Report submitted to the Gulf Coast Survey, Alabama Museum of Natural History, The University of Alabama, Tuscaloosa.

2015 A Reconstruction of the Caddo Salt making Process at Drake's Salt Works. Caddo Archeology Journal 25:145-166.

2016 Salt Production in the Southeastern Caddo Homeland. Ph.D. dissertation, Department of Anthropology, Tuscaloosa, Alabama.

Eubanks, P. N. and E. C. Smith

2012 Report of the 2011 Passport in Time Project at Drake's Salt Works. Project conducted by Winn Ranger District, U.S. Forest Service by Gulf Coast Survey, Alabama Museum of Natural History, Tuscaloosa.

Evans, L.

2012 Amateur Archeologists in the Ouachita River Valley during the Great Depression. M.L.A., Henderson State University, Arkadelphia.

Ewen, C.

1993 A Vacation Without Guilt at Shady Lake. Field Notes (Newsletter of the Arkansas Archeological Society) 251:3-4.

Fant, D. W., D. Turpin, R. Waldon, R. Harbor, G. Stepp, L. Stovall, J. Walston, and M. Barrow

2005 An Archeological Investigation of the Lower Brushy Creek Analysis Area Compartments 950, 953, 954, 955, 979, 980, and 981, Ouachita National Forest, Polk County, Arkansas. Ouachita Cultural Resources Report No. 252. Ouachita National Forest, Hot Springs.

Farley, J. A. and J. D. Keyser 
1979 Little Caney River Prehistory: 1977 Field Season. Contributions in Archaeology No. 5. Laboratory of Archaeology, The University of Tulsa, Tulsa, Oklahoma.

Fauchier, R.

2009 Contextual Analysis of Burial Practices and Associations from a Shallow Fourche Maline Site: Akers 34Lf32. Master's thesis, Department of Anthropology, University of Oklahoma, Norman.

2010 A Preliminary Investigation of Burial Associations from Akers (34LF32): A Shallow Fourche Maline Site in Southeastern Oklahoma. The Arkansas Archeologist 49:33-42.

Faulk, O. B., A. L. Cheek, and T. Zwink

1977 Historical-Cultural Assessment, Federal Coal Lands, Southeastern Oklahoma. Report submitted to Bureau of Land Management, Albuquerque District, Purchase Order No. NM010-77-6. Department of History, Oklahoma State University, Stillwater.

Fay, G. E.

1968 Salvage Archaeology on an Indian Mound in Ouachita County, Arkansas. Miscellaneous Series No. 3. Museum of Anthropology, Colorado State College.

Fenstermaker, G.B.

1937 The King's Room. National Archaeological News 1(7):4-6.

Ferguson, J. R.

2010 Preliminary Report on the Reanalysis of the Texas Caddo NAA Database. In Studies on the Instrumental Neutron Activation Analysis of Woodland Period and Caddo Tradition Ceramics from Eastern Texas, compiled by T. K. Perttula, Article 1. Special Publication No. 17. Friends of Northeast Texas Archaeology, Austin and Pittsburg.

Ferguson, J. R. and M. D. Glascock

2008 Instrumental Neutron Activation Analysis of Caddo Pottery and Clay Samples from the Leaning Rock Site. In "Life on Jackson Creek, Smith County, Texas: Archeological Investigations of a $14^{\text {th }}$ Century Caddo Domicile at the Leaning Rock Site (41SM325)," by M. Walters. Caddo Archeology Journal 17:49-61.

2008 Appendix 13, Instrumental Neutron Activation Analysis of Caddo Pottery and Clay Samples from Texas and Louisiana. In Lake Naconiche Archeology, Nacogdoches County, Texas: Results of the Data Recovery Excavations at Five Prehistoric Archeological Sites, edited by T. K. 
Perttula, pp. A13-1 to A13-23. Report of Investigations No. 60, CD of Appendices. Archeological \& Environmental Consultants, LLC, Austin.

2009 Instrumental Neutron Activation Analysis of Caddo Ceramics from the Ear Spool Site, 41TT653, in Northeastern Texas. In Data Recovery Investigations at the Ear Spool Site (41TT653), Titus County, Texas, by T. K. Perttula and D. L. Sherman, pp. 265-277. Document No. 070205. PBS\&J, Austin.

2009 Instrumental Neutron Activation Analysis. In Archeological Survey and Testing at Lake Whitney, Bosque and Hill Counties, Texas, by R. S. Jones, pp. 273-283. Ecological Communications Corporation, Austin.

2010 Instrumental Neutron Activation Analysis of Ceramic Samples from 41CP28, Camp County, Texas. In National Register of Historic Places Eligibility Testing on Three Late Prehistoric Sites (41CP28, 41CP88 and 41CP414) Within the Leesburg Mine, Camp County, Texas, by D. L. Sherman, L. W. Ellis, C. Heligenstein, S. Laurence, R. Rogers, H. Rush, J. Shipp, and C. Wallace. PBS\&J, Austin.

2010 Instrumental Neutron Activation Analysis of Ceramic Samples from 41CP88, Camp County, Texas. In National Register of Historic Places Eligibility Testing on Three Late Prehistoric Sites (41CP28, 41CP88 and 41CP414) Within the Leesburg Mine, Camp County, Texas, by D. L. Sherman, L. W. Ellis, C. Heligenstein, S. Laurence, R. Rogers, H. Rush, J. Shipp, and C. Wallace. PBS\&J, Austin.

2011 Instrumental Neutron Activation Analysis of Caddo Pottery from Ten Sites in Eastern Texas. In Archeological Investigations at the Lang Pasture Site (41AN38) in the Upper Neches River Basin of East Texas, assembled and edited by T. K. Perttula, D. B. Kelley, and R. A. Ricklis, pp. 591-612. Report 129, Archeological Studies program, Environmental Affairs Division, Texas Department of Transportation, Austin.

2011 Instrumental Neutron Activation Analysis of Toyah Ceramics from 41HY163, Central Texas. In Prehistoric Life, Labor, and Residence in Southeast Central Texas: Results of Data Recovery at 41HY163, the Zapotec Site, San Marcos, Texas, edited by J. C. Lohse, pp. 163-172. Archaeological Studies Report No. 18. Center for Archaeological Studies, Texas State University-San Marcos.

2012 Instrumental Neutron Activation Analysis of Ceramic and Clay Samples from the Pine Tree Mound Site (41HS15), Harrison County, Texas. In Archeology of the Nadaco Caddo: The View from the Pine Tree Mound Site (41HS15), Harrison County, Texas, edited by R. C. Fields and E. F. Gadus, pp. 773-796. 2 Vols. Reports of Investigations No. 164. Prewitt 
and Associates, Inc., Austin.

2013 Neutron Activation Analysis of Ceramics (LWE115-118) from 41RK375, Rusk County, Texas. In NRHP Eligibility Assessment of Sites 41RK322, 41RK375, and 41RK414, Oak Hill Mine, Rusk County, Texas, by D. L. Sherman, L. W. Ellis, B. Harris, M. Nash, and L. Bush, pp. B-1 to B-13. Document No. 120124. Atkins, Austin.

2013 Neutron Activation Analysis of Caddo Ceramics from Five Sites in Oklahoma. Archaeometry Laboratory, University of Missouri, Columbia.

2013 Neutron Activation Analysis of Caddo Ceramics from Ten Sites in Arkansas. Archaeometry Laboratory, University of Missouri, Columbia.

Ferguson, J. R., M. D. Glascock, D. G. Robinson, and T. K. Perttula 2012 Instrumental Neutron Activation Analysis and Petrographic Analysis of Ceramic Sherds. In The Hickory Hill Site (41CP408): Archeological Investigations at a Middle Caddo Site in the Little Cypress Creek Basin in East Texas, by T. K. Perttula and L. W. Ellis, pp. 215-254. Document No. 120055. Atkins, Austin.

Ferguson, J. R., T. K. Perttula, and M. D. Glascock

2010 Dividing Up the Caddo Cultural Landscape: Small-Scale Analysis of a Large Ceramic INAA Database. In Studies on the Instrumental Neutron Activation Analysis of Woodland and Caddo Tradition Ceramics from Eastern Texas, compiled by T. K. Perttula. Article 2, Special Publication No. 17. Friends of Northeast Texas Archaeology, Austin and Pittsburg.

Ferring, C. R.

1982 The Late Holocene Prehistory of the Dyer Site (34PS96), Ti Valley, Oklahoma. Institute of Applied Sciences, North Texas State University, Denton.

Ferring, C. R. (editor)

1994 Past Environments and Prehistory at McGee Creek Reservoir, Atoka County, Oklahoma. Volume V, Part 4, McGee Creek Archaeological Project Reports: Institute of Applied Sciences, University of North Texas, Denton.

Ferring, C. R. and T. K. Perttula

1987 Defining the Provenance of Red-Slipped Pottery from Texas and Oklahoma by Petrographic Methods. Journal of Archaeological Science 14:437-456.

Ferring, C. R. and D. E. Peter 
1987 Geoarchaeology of the Dyer Site, a Prehistoric Occupation in the Western Ouachitas, Oklahoma. Plains Anthropologist 32:351-366.

Ferring, C. R, T. K. Perttula, P. McGuff, and B. C. Yates

1994 Archaeological Investigations at Four Sites along Potapo Creek, McGee Creek Reservoir, Atoka County, Oklahoma. Volume V, Part 3, McGee Creek Archaeological Project Reports. Institute of Applied Sciences, University of North Texas, Denton.

Fields, R. C.

1978 Report on the 1977 Investigations at the George C. Davis Site, Caddoan Mounds State Historic Site, Cherokee County, Texas. Texas Archeological Research Laboratory, The University of Texas at Austin.

1979 Cultural Resources of the Davy Crockett, Sam Houston, Angelina, and Sabine National Forests of Texas. Texas Archeological Research Laboratory The University of Texas at Austin.

1979 Report on the 1977 University of Texas Field School Archeological Survey in Houston County, Texas. Department of Anthropology, The University of Texas at Austin.

1981 Analysis of the Native Made Ceramics from the Deshazo Site, Nacogdoches County, Texas. Master's thesis, Department of Anthropology, The University of Texas at Austin.

1989 Recent Archeological Investigations at the Jewett Mine, East-Central Texas. Caddoan Archeology Newsletter 1(1):14-15.

1990 Recent Archeological Investigations at the Louisiana Army Ammunition Plant, Webster Parish, Louisiana. Caddoan Archeology Newsletter 1(2):37.

1995 Analysis of Native-Made Ceramics. In The Deshazo Site, Nacogdoches County. Texas, Volume 2: Artifacts of Native Manufacture, edited by D. A. Story, pp. 173-232. Studies in Archeology 21. Texas Archeological Research Laboratory The University of Texas at Austin.

1995 Hunter-Gatherer Settlement Strategies in the Oak Woodlands of EastCentral Texas. In Advances in Texas Archeology. Contributions from Cultural Resource Management, edited by J. E. Bruseth and T. K. Perttula, pp. 81-130. Cultural Resource Management Report 5. Department of Antiquities Protection, Texas Historical Commission, Austin. 
1995 The Archeology of the Post Oak Savannah of East Central Texas. Bulletin of the Texas Archeological Society 66:301-330.

2004 The Archeology of the Post Oak Savanna of East-Central Texas. In The Prehistory of Texas, edited by T. K. Perttula, pp. 347-369. Texas A\&M University Press, College Station.

2008 The Pine Tree Mound Site and the Entrada of the Hernando De Soto Expedition of 1542. Journal of Northeast Texas Archaeology 28:1-8.

2014 Ripley Engraved Bowl Motifs and Titus Phase Communities. Posted, February 24, 2014, http://crhrarchaeology.wordpress.com/2014/02/24/ripley-engraved-bowlmotifs-and-titus-phase-communities-fields/.

2014 The Titus Phase from the Top and Bottom: Looking at Sociopolitical Organization through the Pine Tree Mound and U.S. Highway 271 Mount Pleasant Relief Route Projects. Bulletin of the Texas Archeological Society 85:111-146.

2017 The Prairie Caddo Model and the J. B. White Site. Caddo Archeology Journal 27:6-19.

Fields, R. C. (editor)

1989 Archeological Survey and Testing Along Boone Creek, Louisiana Army Ammunition Plant, Webster Parish, Louisiana. Reports of Investigations No. 64. Prewitt and Associates, Inc., Austin.

Fields, R. C. and J. E. Dockall

2017 Current Research in the Sabine Mine's Rusk Permit, Rusk County, Texas. Caddo Archeology Journal 27:94-95.

Fields, R. C. and E. F. Gadus

2012 The Pine Tree Mound Site and the Archeology of the Nadaco Caddo. Bulletin of the Texas Archeological Society 83:23-80.

Fields, R. C. and E. F. Gadus (editors)

2012 Archeology of the Nadaco Caddo: The View from the Pine Tree Mound Site (41HS15), Harrison County, Texas. 2 Vols. Reports of Investigations No. 164. Prewitt and Associates, Inc., Austin.

Fields, R. C. and J. P. Thurmond

1980 The George C. Davis Site, Cherokee County, Texas: Spring 1980 Archeological Investigations. Report of Investigations No. 8. Prewitt and Associates, Inc., Austin. 
Fields, R. C., M. E. Blake, and K. W. Kibler

1997 Synthesis of the Prehistoric and Historic Archaeology of Cooper Lake, Delta and Hopkins Counties, Texas. Reports of Investigations No. 104. Prewitt and Associates, Inc., Austin.

Fields, R. C., E. F. Gadus, and L. W. Klement 1994 The Peerless Bottoms Site: A Late Caddoan Component at Cooper Lake, Hopkins County, Texas. Bulletin of the Texas Archeological Society 65:55114.

Fields, R. C., E. F. Gadus, L. W. Klement, and K. M. Gardner

1994 Excavations at the Spider Knoll Site, Cooper Lake Project, Delta County, Texas. Reports of Investigations No. 96. Prewitt and Associates, Inc., Austin.

Fields, R. C., E. F. Gadus, K. W. Kibler, and L. C. Nordt 2000 Archeological Impact Evaluations and Surveys in the Texas Department of Transportation's Atlanta, Dallas, Fort Worth, Paris, and Waco Districts, 1998-2000. Reports of Investigations No. 128. Prewitt and Associates, Inc., Austin.

Fields, R. C., E. F. Gadus, L. W. Klement, C. B. Bousman, and J. B. McLerran 1993 Excavations at the Tick, Spike, Johns Creek, and Peerless Bottoms Sites, Cooper Lake Project, Delta \& Hopkins Counties, Texas. Report of Investigations No. 91. Prewitt and Associates, Inc., Austin.

Fields, R. C., V. L. Hatfield, D. Burden, E. F. Gadus, M. C. Wilder, and K. W. Kibler

2014 Testing and Data Recovery Excavations at 11 Native American Archeological Sites along the U.S. Highway 271 Mount Pleasant Relief Route, Titus County, Texas. 2 Vols. Reports of Investigations No. 168. Prewitt and Associates, Inc., Austin.

Fields, R. C., S. L. Katauskas, A. E. Dase, and E. F. Gadus 2007 Archeological and Historical Resources Assessment, Sabine Mine's Rusk Reserves, Rusk, Panola, and Gregg Counties, Texas. Prewitt and Associates, Inc., Austin.

Fields, R. C., L. W. Klement, C. B. Bousman, S. A. Tomka, E. F. Gadus, and M. A. Howard

1991 Excavations at the Bottoms, Rena Branch, and Moccasin Springs Sites, Jewett Mine Project, Freestone and Leon Counties, Texas. Report of Investigations No. 82. Prewitt and Associates, Inc., Austin.

Finkelstein, J. J. 
1940 The Norman Site Excavations Near Wagoner, Oklahoma. The Oklahoma Prehistorian 3(3):2-15.

Fischbeck, H. J., J. D. Rogers, S. R. Ryan, and F. E. Swenson

1989 Sourcing Ceramics in the Spiro Region: A Preliminary Study using ProtonInduced X-Ray Emission (PIXE) Analysis. Midcontinental Journal of Archaeology 14:3-17.

Fischbeck, S. L. and S. Loftus

2011 National Register of Historic Places Testing of Sites 41CP27 and $41 C P 417$ in Luminant's Leesburg Mine, Camp County, Texas. Document No. 100095. PBS\&J, Austin.

Fischbeck, S. L., J. E. Dockall, E. F. Gadus, and R. C. Fields

2015 National Register Testing of Seven Native American Sites in the South Hallsville No. 1 Mine-Rusk Permit, Area W, Rusk County, Texas. Reports of Investigations No. 178. Prewitt and Associates, Inc., Austin.

Flaigg, N. G.

1982 A Report on the Analysis of Lithic Material from the Benson's Crossing Site (41TT110), Titus County, Texas. Master's thesis, Department of Anthropology, The University of Texas at Austin.

Fletcher, C.

1980 Cultural Resources Survey and Testing of a 9,000 Acre Tract in the Area of Huntington, Angelina County, Texas. Report No. 7. Cultural Resources Laboratory, Texas A\&M University, College Station.

1980 Archaeological and Historical Cultural Resources Survey in East Angelina County, Texas. Cultural Resources Laboratory, Texas A\&M University, College Station.

Flynn, P.

1976 A Study of Red-Filmed Pottery from the Clement Site (Mc-8), McCurtain County, Oklahoma. Bulletin of the Oklahoma Anthropological Society 25:127-134.

Fogelman, J. A.

2017 Surprise, Surprise: Two Unexpected Lithic Artifact Types from St. Landry Parish. Louisiana Archaeology 42:25-36.

Ford, J. A.

1936 Analysis of Indian Village Site Collections from Louisiana and Mississippi. Anthropological Study No. 2. Department of Conservation, Louisiana Geological Survey, New Orleans. 
1937 Review of Dickinson's "Ceramic Relationships of the pre-Caddo Pottery from the Crenshaw Site." American Antiquity 3(2):195-196.

1951 Greenhouse: A Troyville-Coles Creek Period Site in Avoyelles Parish, Louisiana. Anthropological Papers No. 44(1). American Museum of Natural History, New York.

1952 Measurements of Some Prehistoric Design Developments in the Southeastern States. Anthropological Papers No. 44(3). American Museum of Natural History, New York.

Ford, R. I.

1981 Gardening and Farming before A.D. 1000: Patterns of Prehistoric Cultivation North of Mexico. Journal of Ethnobiology 1(1):6-27.

1982 The Archeobotany of the Deshazo Site. In The Deshazo Site, Nacogdoches County, Texas, Volume 1, edited by D. A. Story, pp. 158163. Texas Antiquities Permit Series No. 7. Texas Antiquities Committee, Austin.

1997 Preliminary Report on the Plant Remains from the George C. Davis Site, Cherokee County, Texas 1968-1970 Excavations. Bulletin of the Texas Archeological Society 68:104-107.

Foster, W. C.

2012 Climate and Culture Change in North America AD 900-1600. University of Texas Press, Austin.

2016 The Last 6,000 Years of Climate and Culture Change in North America. San Bernardino, California.

Fowke, G.

1927 Archaeological Work in Louisiana. Smithsonian Miscellaneous Collections 78(7):254-259.

Fraker, E. L.

1956 With Thoburn at Honey Creek. The Chronicles of Oklahoma 34(1):44-52.

Fransiscus, R. G.

2008 Preliminary Report on the Skeletal Analysis of Burials from the Washington Square Mound Site (41NA49) in Nacogdoches County, Texas. In Documentation of Associated and Unassociated Funerary Objects in the Stephen F. Austin State University Collections, Nacogdoches, Texas, by T. K. Perttula, M. Walters, B. Nelson, B. Gonzalez and R. Cast, pp. 81-92. Historic Preservation Program, Caddo Nation of Oklahoma, Binger, Oklahoma. 
Freeman, J. E.

1959 An Archaeological Report on a Cave Deposit (D1-30) in Northeastern Oklahoma. Archives in Archaeology No. 2. Society for American Archaeology.

1959 The Neosho Focus, a Late Prehistoric Culture in Northeastern Oklahoma. Ph.D. dissertation, Department of Anthropology, University of Wisconsin, Madison.

1960 Site DL-29, a Rockshelter in Northeastern Oklahoma. Archives in Archaeology No. 8. Society for American Archaeology.

1962 The Neosho Focus: A Late Prehistoric Culture in Northeastern Oklahoma. Bulletin of the Oklahoma Anthropological Society 10:1-26.

Freeman, J. E. and A. D. Buck

1960 Woodward Plain and Neosho Punctate, Two Shell Tempered Pottery Types of Northeastern Oklahoma. Bulletin of the Oklahoma Anthropological Society 8:3-16.

Frink, D. S. and T. K. Perttula

2001 Analysis of the 39 Oxidizable Carbon Ratio Dates from Mound A, Mound $\mathrm{B}$, and the Village Area at the Calvin Davis or Morse Mounds Site (41SY27). North American Archaeologist 22(2):143-160.

Fritz, G.

1975 Analysis of Ceramic Pipes, Ear Ornaments, and Effigies from the George C. Davis Site. Master's thesis, Department of Anthropology, The University of Texas at Austin.

1982 Analysis of Plant Remains from the Spiro Site, 3411-46, LeFlore County, Oklahoma. In Spiro Archaeology: 1980 Research, by J. D. Rogers, pp. 201-213. Studies in Oklahoma's Past No. 9. Oklahoma Archeological Survey, Norman.

1982 Analysis of Archaeological Plant Remains from Thirteen Madison County, Arkansas, Bluff Shelter Sites. Graduate School, University of North Carolina at Chapel Hill.

1984 Identification of Cultigen Amaranth and Chenopod from Rock Shelter Sites in Northwest Arkansas. American Antiquity 49(3):558-572.

1986 Prehistoric Ozark Agriculture: The University of Arkansas Rockshelter Collections. Ph.D. dissertation, Department of Anthropology, University of North Carolina-Chapel Hill. 
1986 Desiccated Botanical Remains from Three Bluffshelter Sites in the Pine Mountain Project Area, Crawford County, Arkansas. In Contributions to Ozark Prehistory, edited by G. Sabo, III, pp. 86-97. Research Series No. 27. Arkansas Archeological Survey, Fayetteville.

1986 Mounds in Northwest Arkansas: A More Positive Approach to the Late Prehistory in the Ozarks. In Contributions to Ozark Prehistory, edited by G. Sabo, III, pp. 49-54. Research Series No. 27. Arkansas Archeological Survey, Fayetteville.

1989 Evidence of Plant Use From Copple Mound at the Spiro Site. In Contributions to Spiro Archeology: Mound Excavations and Regional Perspectives, edited by J. D. Rogers, D. G. Wyckoff, and D. A. Peterson, pp. 65-87. Studies in Oklahoma's Past No. 16. Oklahoma Archeological Survey, Norman.

1990 Multiple Pathways to Farming in Precontact North America. Journal of World Prehistory 4:387-435.

1994 In Color and in Time: Prehistoric Ozark Agriculture. In Agricultural Origins and Development in the Midcontinent, edited by W. Green, pp. 105-126. Office of the State Archeologist, University of lowa, lowa City.

1997 A three-thousand year old cache of crop seeds from Marble Bluff, Arkansas. In People, Plants, and Landscapes: Studies in Paleoethnobotany, edited by K. J. Gremillion, pp. 42-62. University of Alabama Press, Tuscaloosa.

2014 Maygrass (Phalaris caroliniana Walt.): Its Role and Significance in Native Eastern North American Agriculture. In New Lives for Ancient and Extinct Crops, edited by P. E. Minnis, pp. 12-43. University of Arizona Press, Tucson.

Fritz, G. J. and R. H. Ray

1982 Rock Art Sites in the Southern Ozarks. In Arkansas Archeology in Review, edited by N. L. Trubowitz and M. D. Jeter, pp. 240-276. Research Series No. 15. Arkansas Archeological Survey, Fayetteville.

Fulton, R. L. and C. H. Webb

1953 The Bellevue Mound: A Pre-Caddoan Site in Bossier Parish, Louisiana. Bulletin of the Texas Archeological Society 24:18-42.

Gadus, E. F.

2003 Test Excavations at 41HE257, Henderson County, Texas. Technical Report No. 64. Prewitt and Associates, Inc., Austin. 
2013 Twisted Serpents and Fierce Birds: Structural Variation in Caddo Engraved Ceramic Bottle Motifs. Bulletin of the Texas Archeological Society 84:213-245.

Gadus, E. F. and R. C. Fields

1996 Ceramic Vessels from the Pleasure Point Site (41MR63), Marion County, Texas. Technical Reports No. 22. Prewitt and Associates, Inc., Austin.

Gadus, E. F., R. C. Fields, and C. B. Bousman

1992 Archeological Investigations at 41DT11, 41DT21, 41DT50, 41DT54, and 41DT63 at Cooper Lake, Delta County, Texas. Reports of Investigations No. 86. Prewitt and Associates, Inc., Austin.

Gadus, E. F., R. C. Fields, and K. W. Kibler

2006 Data Recovery Excavations at the J. B. White Site (41MM341), Milam County, Texas. Reports of Investigations No. 145, Prewitt and Associates, Inc., and Report No. 87, Archeological Studies Program, Environmental Affairs Division, Texas Department of Transportation, Austin.

Gadus, E. F., M. D. Freeman, and R. C. Fields

1998 Archeological Survey of 319 Hectares at the Longhorn Army Ammunition Plant; Harrison County, Texas. Reports of Investigations No. 119. Prewitt and Associates, Inc., Austin.

Gadus, E. F., J. K. McWilliams, and R. C. Fields

2002 Data Recovery Excavations at the McGuire's Garden Site (41FT425),

Jewett Mine, Freestone County, Texas. Reports of Investigations No. 134. Prewitt and Associates, Inc., Austin.

Gadus, E. F., R. C. Fields, J. K. McWilliams, J. Dockall, and M. C. Wilder 2006 National Register Testing of Seven Prehistoric Sites in the Sabine Mine's Area Q, Harrison County, Texas. Reports of Investigations, Number 147. Prewitt and Associates, Inc., Austin.

Gaither, S., T. K. Perttula, and G. Cheatwood

1991 The Cheatwood Place (41 RR181), a Midden Mound along Little Mustang Creek, Red River County, Texas. Caddoan Archeology Newsletter 2(1):21-28.

Gaither, S., C. Neel, A. J. Schitz, T. Baugh, K. Kahl, J. Whaley, M. McMinn, and J. Fry

2003 Cultural Resources Inventory of 6,800 Acres and National Register Eligibility Evaluation of Eight Archaeological Sites, Camp Gruber Army National Guard Training Center, Muskogee County, Oklahoma. Camp 
Gruber Technical Series, Report of Investigations Number 3. Lopez Garcia Group, Dallas.

Gaither, S., S. A. Sundermeyer, and S. N. DeFreece

2004 Cultural Resources Investigations at Six Study Areas Within the Tar Creek Superfund Site. Miscellaneous Reports, Report of Investigation Number 7. Lopez Garcia Group, Dallas.

Galan, V.

1998 Excavations at 41TT653, the Ear Spool Site. CRM News \& Views 10(2):21-25. Archeology Division, Texas Historical Commission, Austin.

2006 A Cultural Resources Survey of the Levine \#2 Well Location and Access Road and Limited Testing of 41GG104, Gregg County, Texas. Archaeological Report 177. Deep East Texas Archaeological Consultants, Nacogdoches.

2011 A Cultural Resources Survey of the Mt. Pleasant Water Pipeline, Titus County, Texas. Archaeological Report 269. Deep East Texas Archaeological Consultants, Nacogdoches.

2011 Cultural Resources Survey of the Nacogdoches DWSRF 2005 Water Pipeline, Nacogdoches County, Texas. Deep East Texas Archaeological Consultants, Nacogdoches.

2012 Cultural Resources Survey of the Lindsey Park Improvements for the City of Tyler, Smith County, Texas. Archaeological Report No. 469. Deep East Texas Archaeological Consultants, Nacogdoches.

Galan, V. and S. Bibby

2011 A Cultural Resources Survey of the Williams' Poultry Facility in Hopkins County, Texas. Report No. 407. Deep East Texas Archaeological Consultants, Nacogdoches.

Galan, V. and P. Brown

2009 A Cultural Resources Survey of the Andy Gardner Property, Nacogdoches County, Texas. Report No. 289. Deep East Texas Archaeological Consultants, Nacogdoches.

Galan, V. and M. Cruse

1997 Cultural Resources Survey (Alto-Pine Grove and Pine Grove Jacksonville) 138-KV Transmission Lines, Cherokee County, Texas. Document No. 971022. Espey, Huston \& Associates, Inc., Austin.

Galan, V., R. Rogers, T. K. Perttula, and E. S. Switek 
1997 National Register Testing of Seven Sites in the Monticello B-2 Surface Mine, Titus County, Texas. Document No. 971085. Espey, Huston \& Associates, Inc., Austin.

Galloway, M. K., S. W. Hammerstedt, and A. L. Regnier

2010 Archeological Survey of Evansville Creek, Adair County, Oklahoma. Archeological Resource Survey Report No. 62. Oklahoma Archeological Survey, Norman.

Galm, J.

1978 The Archeology of the Curtis Lake Site (34Lf-5A), LeFlore County, Oklahoma. Research Series No. 2. Archaeological Research and Management Center, University of Oklahoma, Norman.

1978 Archaeological Investigations at Wister Lake, LeFlore County, Oklahoma. Research Series No. 1. Archaeological Research and Management Center, University of Oklahoma, Norman.

1978 The Wister Lake Archaeological Project. Oklahoma Anthropological Society Newsletter 26(1):1-2.

1981 Prehistoric Cultural Adaptations in the Wister Valley, East Central Oklahoma. Ph.D. dissertation, Department of Anthropology, Washington State University, Pullman.

1984 Arkansas Valley Caddoan Formative: The Wister and Fourche Maline Phases. In Prehistory of Oklahoma, edited by R. E. Bell, pp. 199-219. Academic Press, New York.

n.d. Phase II Investigations at the Briar Locality, Le Flore County, Oklahoma. MS on file at the Archaeological Research and Management Center, University of Oklahoma, Norman.

Galm, J. and P. Flynn

1978 The Cultural Sequence at the Scott (34LF-11) and Wann (34LF-27) Sites and the Prehistory of the Wister Valley. Research Series 3. Archaeological Research and Management Center, University of Oklahoma, Norman.

1978 New Radiocarbon Dates for Sites in the Wister Valley, Eastern Oklahoma. Oklahoma Anthropological Society Newsletter 26(5):2-5.

Galm, J. R. and P. Flynn (editors)

1978 Archaeological Investigations in the Rosehill Mining Area, Haskell County, Oklahoma. Project Report Series No. 3. Archaeological Research and Management Center, University of Oklahoma, Norman. 
Gannon, T. N.

2001 Camp Clearfork-Crystal Springs Waterline. Project No. 08-09-10-423. Ouachita National Forest, Hot Springs.

2001 Ice Damage Recovery: IS Area 7. Ouachita National Forest, Hot Springs.

2003 An Archeological Survey of Proposed Remediation Areas at the Victor Coal Mine Complex, Logan County, Arkansas. Effigy Archeological Services, Overland Park.

2005 A Phase 1 Archeological Survey of Approximately Ten Acres for a Proposed Lake near Boyd Hill, Lafayette County, Arkansas. EAS Project No. 04-07, Final Report. Effigy Archeological Services, Inc., Overland Park.

Gannon, T. N., D. St. Germain, A. L. Morebe, and C. S. Spears 1999 An Archeological Survey of 8,173 Acres in the Fourche, Womble, and Caddo Ranger Districts of the Ouachita National Forest, Garland, Montgomery, Perry, Polk, and Yell Counties, Arkansas. 2 Vols. Project Report 123. Spears Professional Environmental and Archeological Research Service, West Fork, Arkansas.

Gannon, T., C. S. Spears, D. St. Germain, and D. Chenault

1997 An Archeological Survey of 3, 062 Acres in the Jessieville, Cold Springs, and Caddo Ranger Districts of the Ouachita National Forest, Garland, Scott, and Montgomery Counties, Arkansas. Project Report 118. Spears Professional Environmental and Archeological Research Service, Inc., West Fork, Arkansas.

Gannon, T., C. S. Spears, T. DeBoer, A. L. Moerbe, P. Roberts, and R. Wick 1996 An Archeological Survey of 743 Acres in the Fourche Ranger District of the Ouachita National Forest, Yell County, Arkansas. Project Report 117. Spears Professional Environmental and Archeological Research Service, Inc., West Fork, Arkansas.

Gannon, T., C. S. Spears, A. L. Moerbe, D. Chenault, M. Memory, and R. Wick 1996 An Archeological Survey of 1682 Acres in the Mena Ranger District of the Ouachita National Forest, Polk County, Arkansas. Project Report 111. Spears Professional Environmental and Archeological Research Service, Inc., West Fork, Arkansas.

Gao, X., M. Norwood, C. Frederick, A. McKee, C. A. Masiello, and P. Louchouarn 2016 Organic geochemical approaches to identifying formation processes for middens and charcoal-rich features. Organic Geochemistry 94:1-11.

Gardner, B. B. 
1930 Excavation of a Burial Site on W. S. Russell Farm, in Titus County, Texas. MS on file, Texas Archeological Research Laboratory, The University of Texas at Austin.

1931 Some Specimens of East Texas Pottery: Distribution, Types and Decoration. Master's thesis, Department of Anthropology, The University of Texas at Austin.

Gardner, J. S.

1980 The Conservation of Fragile Specimens from the Spiro Mound, LeFlore County, Oklahoma. Contributions No. 5. Stovall Museum, University of Oklahoma, Norman.

Gardner, P. S.

1997 Plant Remains. In Two Caddoan Farmsteads in the Red River Valley: The Archeology of the McLelland and Joe Clark Sites, edited by D. B. Kelley, pp. 109-120. Research Series 51. Arkansas Archeological Survey, Fayetteville.

Gaston, D. J. and D. O. Henry

1989 Archaeological Survey at the Proposed Tuskahoma Lake: 1987. Laboratory of Archaeology, The University of Tulsa, Tulsa.

Gattis, P.

1998 Florence-A Chert and the Economic Control of a Mississippian Chiefdom. Master's thesis, Department of Anthropology, The University of Oklahoma, Norman.

Gearhart, R. L.

1997 East Texas Electric Cooperative, Inc. Cultural Resources Survey (SlocumAlto Segment), Anderson and Cherokee Counties, Texas. Document No. 970334. Espey, Huston \& Associates, Inc., Austin.

Gettys, A. F.

1978 Radiocarbon Dates from Hs-25, Otter Creek \#1 Site, Haskell County, Oklahoma. Oklahoma Anthropological Society Newsletter 26(2):1.

1981 A Preliminary Bibliography of Ceramic Period Sites in the Eastern Part of the Red River Drainage of Oklahoma, and Texas. Archeological Assessments Inc., Nashville, Arkansas.

1983 Literature Search for Botanical Materials from Excavations in Southeast Oklahoma. MS on file, Oklahoma Archeological Survey, Norman.

Gettys, M. 
1975 Preliminary Report on Archaeological Investigations at Lufkata Reservoir, Southeastern Oklahoma. General Survey Report No. 14. Oklahoma River Basin Survey Project, University of Oklahoma, Norman.

Gibson, J. L.

1969 Archaeological Survey at Caddo Lake, Louisiana and Texas. Contributions in Anthropology No. 6. Department of Anthropology, Southern Methodist University, Dallas.

1977 Cultural Resources Survey of the Cognac Revetment Red River Waterway, Natchitoches Parish, Louisiana. U.S. Army Corps of Engineers, New Orleans.

1978 An Archaeological Reconnaissance of the Lower Sabine River Valley Toledo Bend Dam to Gulf Intercoastal Waterway, Louisiana and Texas, Calcasieu, Beauregard, Sabine, and Vernon Parishes. Center for Archaeological Studies, University of Southwest Louisiana, Lafayette.

1982 Archeological Reconnaissance in the Big Sandy Drainage Basin: An Empirical Approach to Investigating Settlement in East Texas. Center for Archaeological Studies, University of Southwest Louisiana, Lafayette.

1983 An Evaluatory History of Archaeology in the Ouachita Valley of Louisiana. Louisiana Archaeology 10:25-101.

1983 Ouachita Prehistory. Louisiana Archaeology 10:319-335.

2005 Bossier Tribes, Caddo in North Louisiana's Pineywoods. Caddoan Archeology Journal 14:93-118.

Gibson, J. L. (editor)

1980 "Caddoan and Poverty Point Archaeology: Essays in Honor of C. H. Webb." Louisiana Archaeology 6 (whole volume).

Gibson, J. L., P. C. Cook, C. A. Brasseaux, F. L. Martin, and E. L. Gibson 1992 Piney Woods Past: Cultural Resources Inventory of North Central Louisiana, U.S. 167 and U.S. 425 Corridor. Report on file at the Louisiana Division of Archaeology, Department of Culture, Recreation, and Tourism, Baton Rouge.

Gifford, C. and G. H. Odell

1999 Digging in Museums: WPA Archaeology in the Grand River Valley as Seen from the Duck Creek Site. Bulletin of the Oklahoma Anthropological Society 48:83-111.

Gill-King, $\mathrm{H}$. 
1999 Human Skeletal Remains: Pathological and Dietary/Nutritional Aspects. In The Hurricane Hill Site (41HP106): The Archaeology of a Late Archaic/Early Ceramic and Early-Middle Caddoan Settlement in Northeast Texas, edited by T. K. Perttula, pp. 329-343. Special Publication No. 4. Friends of Northeast Texas Archaeology, Pittsburg and Austin.

Gilliland, J. E., K. Bohon, J. Roberts, and H. Huffman

2009 Final Report on Archaeological Mitigation of Frog Bayou Shelter, 3CW946, for the Lake Fort Smith Water Supply Project, Crawford County, Arkansas. Burns \& McDonnell Engineering Company, Inc., Kansas City, Missouri.

2009 Report on Archaeological Mitigation of the Copperhead Site, 3CW951, for the Lake Fort Smith Water Supply Project, Crawford County, Arkansas. Burns \& McDonnell Engineering Company, Inc., Kansas City, Missouri.

Gilmore, K.

1983 Caddoan Interaction in the Neches Valley, Texas. Reprints in Anthropology No. 27. J\&L Reprint Company, Lincoln.

1986 French-Indian Interaction at an Early Eighteenth Century Post: The Roseborough Lake Site, Bowie County, Texas. Contributions in Archaeology 3. Institute of Applied Sciences, North Texas State University, Denton.

1991 An Archeological Footnote to History. Bulletin of the Texas Archeological Society 60:303-324.

1996 A. C. Saunders Site. In The New Handbook of Texas, Vol. 1, edited by R. Tyler, p. 1. Texas State Historical Association, Austin.

Gilmore, K. K. and N. Hoffrichter

1964 Preliminary Investigations, L. O. Ray Site, Delta County, Texas. The Record 19(1):3-17. Dallas Archeological Society, Dallas.

Gilmore, K. and O. McCormick

1980 Red River Archaeological Project, Phase I. Institute of Applied Sciences, North Texas State University, Denton.

1982 Red River Archaeological Project, Phase II. Institute of Applied Sciences, North Texas State University, Denton.

Gilmore, M. R.

1931 Vegetal Remains of the Ozark Bluff Dweller Culture. Papers of the Michigan Academy of Science, Ats, and Letters 14:83-105.

Girard, J. S. 
1982 The Chipped Stone Collection from the Deshazo Site (41 NA27): A Technological Functional and Typological Analysis. Master's thesis, Department of Anthropology, The University of Texas at Austin.

1990 Northwest Louisiana Regional Archaeology Program, First Annual Report. Northwestern State University, Natchitoches.

1991 Northwest Louisiana Regional Archaeology Program, Second Annual Report. Northwestern State University, Natchitoches.

1992 Regional Archaeology Program, Management Unit 1: Third Annual Report. Northwestern State University, Natchitoches.

1993 Regional Archaeology Program, Management Unit 1: Fourth Annual Report. Northwestern State University, Natchitoches.

1994 Regional Archaeology Program, Management Unit 1: Fifth Annual Report. Northwestern State University, Natchitoches.

1994 Investigations at the James Pace Site (16DS268), DeSoto Parish, Louisiana. Caddoan Archeology Newsletter 5(1):8-16.

1995 Regional Archaeology Program, Management Unit 1: Sixth Annual Report. Northwestern State University, Natchitoches.

1995 An Early Ceramic Period Pit Feature at the Swan Lake Site (16B011), Bossier Parish, Louisiana. Caddoan Archeology Newsletter 5(4):6-11.

1995 The Chipped Stone Collection: Technological, Functional, and Typological Analyses. In The Deshazo Site, Nacogdoches County, Texas, Volume 2: Artifacts of Native Manufacture, edited by D. A. Story, pp. 33-156. Studies in Archeology 21. Texas Archeological Research Laboratory, The University of Texas at Austin.

1996 Regional Archaeology Program, Management Unit 1: Seventh Annual Report. Northwestern State University, Natchitoches.

1997 Historic Caddoan Occupation in the Natchitoches Area: Recent Attempts to Locate Residential Sites. Caddoan Archeology 8(3):19-31.

1997 Regional Archaeology Program, Management Unit 1: Eighth Annual Report. Northwestern State University, Natchitoches.

1997 Caddoan Settlement in the Red River Floodplain: Perspectives from the Willow Chute Bayou Area, Bossier Parish, Louisiana. Louisiana Archaeology 22:143-162. 
1998 Excavations at the Fredericks Site (16NA2), Regional Archaeology Program, Management Unit 1: Ninth Annual Report. Report on file at the Louisiana Division of Archaeology, Department of Culture, Recreation, and Tourism, Baton Rouge.

1999 Regional Archaeology Program, Management Unit 1: Tenth Annual Report. Report on file at the Louisiana Division of Archaeology, Department of Culture, Recreation, and Tourism, Baton Rouge.

1999 Late Caddoan Occupation along Cowhide Bayou: An Update on the Belcher Mound and Village Sites. Caddoan Archeology 10(3):3-27.

2000 Regional Archaeology Program, Management Unit 1: Eleventh Annual Report. Report on file at the Louisiana Division of Archaeology, Department of Culture, Recreation, and Tourism, Baton Rouge.

2000 Excavations at the Fredericks Site, Natchitoches Parish, Louisiana. Louisiana Archaeology 22:143-162.

2001 Regional Archaeology Program, Management Unit 1: Twelfth Annual Report. Report on file at the Louisiana Division of Archaeology, Department of Culture, Recreation, and Tourism, Baton Rouge.

2002 Regional Archaeology Program, Management Unit 1: Thirteenth Annual Report. Report on file at the Louisiana Division of Archaeology, Department of Culture, Recreation, and Tourism, Baton Rouge.

2002 Phelps Lake and Jim Burt: Two Middle Woodland Period Mounds in Northwestern Louisiana. Caddoan Archeology 12(4):5-17.

2003 Regional Archaeology Program, Management Unit 1: Fourteenth Annual Report. Report on file at the Louisiana Division of Archaeology, Department of Culture, Recreation, and Tourism, Baton Rouge.

2004 Regional Archaeology Program, Management Unit 1: Fifteenth Annual Report. Report on file at the Louisiana Division of Archaeology, Department of Culture, Recreation, and Tourism, Baton Rouge.

2005 Regional Archaeology Program, Management Unit 1: Sixteenth Annual Report. Report on file at the Louisiana Division of Archaeology, Department of Culture, Recreation, and Tourism, Baton Rouge.

2006 Regional Archaeology Program, Management Unit 1: Seventeenth Annual Report. Report on file at the Louisiana Division of Archaeology, Department of Culture, Recreation, and Tourism, Baton Rouge. 
2007 Regional Archaeology Program, Management Unit 1: Eighteenth Annual Report. Report on file at the Louisiana Division of Archaeology, Department of Culture, Recreation, and Tourism, Baton Rouge.

2007 Byram Ferry (16BO17): A Middle to Late Caddo Period Mound Site in the Red River Floodplain, Northwest Louisiana. Caddo Archeology Journal 16:9-25.

2007 Sites in Northern Louisiana with Major Collections of Historic Caddo and other Native American Pottery. Journal of Northeast Texas Archaeology 26:24-32.

2008 Regional Archaeology Program, Management Unit 1: Nineteenth Annual Report. Report on file at the Louisiana Division of Archaeology, Department of Culture, Recreation, and Tourism, Baton Rouge.

2009 Issues Regarding the Early Development of Caddo Culture: Discussion Topics for the East Texas Caddo Research Group, December 2008. Journal of Northeast Texas Archaeology 31:47-48.

2009 Comments on Caddo Origins in Northwest Louisiana. Journal of Northeast Texas Archaeology 31:51-60.

2009 Regional Archaeology Program, Management Unit 1: Twentieth Annual Report. Report on file at the Louisiana Division of Archaeology, Department of Culture, Recreation, and Tourism, Baton Rouge.

2010 Caddo Communities of Northwest Louisiana. In Archaeology of Louisiana, edited by M. A. Rees, pp. 195-210. Louisiana State University Press, Baton Rouge.

2010 Regional Archaeology Program, Management Unit 1: Twenty First Annual Report. Report on file at the Louisiana Division of Archaeology, Department of Culture, Recreation, and Tourism, Baton Rouge.

2010 Vessels from the Belcher Site in the Williamson Museum Collections. CD Publication, Northwestern State University of Louisiana, Natchitoches.

2011 Regional Archaeology Program, Management Unit 1: Twenty Second Annual Report. Report on file at the Louisiana Division of Archaeology, Department of Culture, Recreation, and Tourism, Baton Rouge.

2012 Regional Archaeology Program, Management Unit 1: Twenty Third Annual Report. Report on file at the Louisiana Division of Archaeology, Department of Culture, Recreation, and Tourism, Baton Rouge.

2012 The Bellevue Site (16BO4): A Woodland Period Mound in Northwest Louisiana. Louisiana Archaeology 35:53-77. 
2012 Focus Placed on the Bellevue Mound in Bossier Parish. Newsletter of the Louisiana Archaeological Society 39(3):26-27.

2012 Recent Investigations at the Mounds Plantation Site (16CD12), Caddo Parish, Louisiana. Caddo Archeology Journal 22:21-62.

2012 Settlement Patterns and Variation in Caddo Pottery Decoration: A Case Study of the Willow Chute Bayou Locality. In The Archaeology of the Caddo, edited by T. K. Perttula and C. P. Walker, pp. 239-287. University of Nebraska Press, Lincoln.

2013 Report of the $54^{\text {th }}$ Caddo Conference. Caddo Archeology Journal 23:157164.

2013 Return to the Fish Creek Site (16GR17) in Grant Parish. Newsletter of the Louisiana Archaeological Society 41(1):24-25.

2013 Regional Archaeology Program, Management Unit 1: Twenty Fourth Annual Report. Report on file at the Louisiana Division of Archaeology, Department of Culture, Recreation, and Tourism, Baton Rouge.

2014 The W. W. Todd Collection of the Lincoln Parish Museum. Newsletter of the Louisiana Archaeological Society 41(3):20-22.

2014 The James Pace Site (16DS268) and Early Caddo Developments Along the Upper Sabine River. Bulletin of the Texas Archeological Society 85:6181.

2015 Survey along Red Bayou in Northern Caddo Parish. Newsletter of the Louisiana Archaeological Society 43(3):17-18.

2015 Regional Archaeology Program, Management Unit 1: Twenty Sixth Annual Report. Report on file at the Louisiana Division of Archaeology, Department of Culture, Recreation, and Tourism, Baton Rouge.

2017 Review of "Caddo Landscapes in the East Texas Forests". Louisiana Archaeological Society Newsletter 45(2):27-28.

Girard, J. S. and L. G. Cecil

2016 Comparing Caddo and Coles Creek Pottery Using Petrographic Analysis. Caddo Archeology Journal 26:7-18.

Girard, J. S. and H. F. Gregory

2002 Archaeological and Historical Perspectives on Eighteenth Century Native American Settlement in the Cane River Region. In Archaeology, Interpretation, and Management in Cane River National Heritage Area, 
Symposium Proceedings, edited by N. Morgan and J. Shatwell, pp. 20-31. Cane River National Heritage Area Commission, Natchitoches.

Girard, J. S., H. E. Jackson, and K. M. Roberts

2006 Fish Hatchery 2 (16NA70): A Late Prehistoric Site on the Caddo-Lower Mississippi Valley Margin. Louisiana Archaeology 27:15-70.

Girard, J. S. and T. K. Perttula

2012 Artifacts in the Raymond Powell Collection from East Texas. Journal of Northeast Texas Archaeology 36:77-79.

2016 Copper Artifacts from Caddo Sites in the Southern Caddo Area. Caddo Archeology Journal 26:19-28.

Girard, J. S., T. K. Perttula, and M. B. Trubitt

2014 Caddo Connections: Cultural Interactions Within and Beyond the Caddo World. Rowan \& Littlefield, Lanham, Maryland.

Girard, J. S., R. C. Vogel, and H. E. Jackson

2008 History and Archaeology of the Pierre Robleau Household and Bayou Pierre Community: Perspectives on Rural Society and Economy in Northwestern Louisiana at the Time of the Freeman and Custis Expedition. In Freeman and Custis Red River Expedition of 1806: Two Hundred Years Later, edited by L. M. Hardy, pp. 147-180. Bulletin of the Museum of Life Sciences No. 14. Museum of Life Sciences and James Smith Noel Collection, Noel Memorial Library, Louisiana State University in Shreveport.

Glander, W. P.

1984 Further Cultural Resource Investigations within the Martin Lake Mine C-II Permit Area, Panola County, Texas. Document No. 84773. Espey, Huston \& Associates, Inc., Austin.

Glander, W. P. and C. Brandimarte

1983 Cultural Resources Survey of the Martin Lake Site: Tracts A, B, and C, Panola County, Texas. Document No. 83121. Espey, Huston \& Associates, Inc., Austin.

Glander, W. P. and S. Victor

1984 Additional Cultural Resource Investigations at the Martin Lake Mine Tracts $A, B$, and C. Document No. 83718. Espey, Huston \& Associates, Inc., Austin.

Glander, W. P., L. K. Jones, D. Moore, C. Frederick, and N. Barker 1987 Cultural Resource Investigations of the Oak Hill Mine, Rusk County, Texas. Document No. 870695. Espey, Huston \& Associates, Inc., Austin. 
Glander, W., G. Sundborg, D. Moore, D. Brown, N. Barker, D. Jurney, K. White, and $\mathrm{L}$. Jones

1993 Cultural Resources Survey of the Proposed Monticello-Leesburg Coal Surface Mine, Camp County, Texas. Document No. 861094. Espey, Huston \& Associates, Inc., Austin.

Glander, W., S. Victor, T. Bearden, M. Turnbough, D. Jurney, K. White, and S. Tomka

1986 A Report on Continued Cultural Resources Investigations of the Martin Lake Coal Surface Mine, Tracts A B \& G, Panola County, Texas.

Document No. 851165. Espey, Huston \& Associates, Inc., Austin.

Glander, W., S. Victor, M. Turnbough, G. Sundborg, D. Jurney, K. White, and S. Tomka

1986 Cultural Resources Survey of the Monticello-Winfield Coal Surface Mine, Titus County, Texas. Document No. 85417. Espey, Huston \& Associates, Inc., Austin.

Glasgow, M. (editor)

1990 The Chambers Site, 41TR114. Tarrant County Archaeological Society, Fort Worth.

Godwin, M.

2000 A Cultural Resources Survey of Mena, Arkansas, to Craig Junction, Oklahoma, 138-KV Transmission Line Polk County, Arkansas and McCurtain County, Oklahoma. Heritage Management Series, Survey Report No. 17. Antiquities Planning and Consulting, Kyle.

Godwin, M. F., P. Maslyk, G. High, and W. J. Weaver

2000 A Cultural Resources Survey of the Mena, Arkansas to Craig Junction, Oklahoma 138kV Transmission Line, Polk County, Arkansas, and McCurtain County, Oklahoma. Report prepared for Southwestern Electric Power Company, URS Dames \& Moore, Austin, Texas, and American Electric Power, Dallas, Texas. Antiquities Planning and Consulting, Kyle.

Goldborer, S. E.

1991 Maize and Prehistoric Subsistence in the Oklahoma Cross Timbers: A Model for Post-Woodland Warm-Season Precipitation Decline. Master's thesis, Department of Anthropology, University of Oklahoma, Norman.

Goldschmidt, W. R.

1934 Excavation of a Burial Site on Thomas B. Caldwell Plantation in Titus County, Texas. MS on file, Texas Archeological Research Laboratory, The University of Texas at Austin. 
1934 Field Report of an Excavation through the George L. Keith Mound, Titus County, Texas; and Test Trenching on the C. T. Coley Farm. MS on file, Texas Archeological Research Laboratory, The University of Texas at Austin.

1934 Excavation of a Burial Site on A. P. Williams Farm in Titus County, Texas. MS on file, Texas Archeological Research Laboratory, The University of Texas at Austin.

1934 Field Notes, W. A. Ford Site, Titus County, Texas, August 21, 1934 to September 5, 1934. MS on file, Texas Archeological Research Laboratory, The University of Texas at Austin.

1935 A Report on the Archeology of Titus County in East Texas. Bulletin of the Texas Archeological and Paleontological Society 7:89-99.

1935 Some Archeological Sites in Titus County and Their Relation to East Texas Prehistory. Master's thesis, Department of Anthropology, The University of Texas at Austin.

Goldstein, M. S.

1940 Cranial Deformation among Texas Indians. American Journal of Physical Anthropology 27:312-314.

1957 Skeletal Pathology of Early Indians in Texas. American Journal of Physical Anthropology 15:299-311.

Gonzalez, B.

2005 Caddo tribal religious burial ceremonies beyond archeology. In $A$ Rediscovering of Caddo Heritage: The W. T. Scott Collection at the American Museum of Natural History and Other Caddo Collections from Arkansas and Louisiana, by B. Gonzalez, R. L. Cast, T. K. Perttula, and B. Nelson, pp. 55-59. Historic Preservation Program, Caddo Nation of Oklahoma, Binger.

Gonzalez, B., R. L. Cast, T. K. Perttula, and B. Nelson 2005 A Rediscovering of Caddo Heritage: The W. T. Scott Collection at the American Museum of Natural History and Other Caddo Collections from Arkansas and Louisiana. Historic Preservation Program, Caddo Nation of Oklahoma, Binger.

Good, C. E.

1982 Analysis of Structures, Burials and other Cultural Features. In The Deshazo Site, Nacogdoches County Texas, Volume 1, edited by D. A. Story, pp. 51-112. Texas Antiquities Permit Series No. 7. Texas Antiquities Committee, Austin. 
Goode, G. T.

1997 Test Excavations at Prehistoric Site 41SM203, Smith County, Texas. Archeological Studies Program, Texas Department of Transportation, Austin.

1997 An Assessment of Prehistoric Sites 41CP228 and 41CP229, Camp County, Texas. Archeological Studies Program, Texas Department of Transportation, Austin.

Goode, G. T., S. Hays, P. Maslyk, C. G. Ward, and J. Gonzales 1997 Significance Testing at Prehistoric Archeological Site 41RK195, Rusk County, Texas. Archeological Studies Program, Texas Department of Transportation, Austin.

Goode, G. T., T. K. Perttula, L. L. Bush, S. Marceaux, L. Schniebs, and J. Todd 2015 Excavations at the Early Caddo Period Mound Pond Site (41HS12) in Harrison County, Texas. Special Publication No. 38. Friends of Northeast Texas Archeology, Austin and Pittsburg.

Goodmaster, C.

2011 Pine Mountain Reprised: A Cultural and Historic Context of the Upper Lee Creek Valley, Crawford County, Arkansas. Miscellaneous Reports of Investigations No. 498. Geo-Marine, Inc., Plano, Texas.

2012 Cultural Resources Damage Assessment: SASI Ranch \#3-5, Wood County, Texas. Miscellaneous Reports of Investigations No. 558. GeoMarine, Inc., Plano.

2012 Archeological Monitoring for Trail Construction, Caddo Mounds State Historic Site, Cherokee County, Texas. Miscellaneous Reports of Investigations No. 557. Geo-Marine, Inc., Plano.

2012 Class III Cultural Resources Inventory of the Proposed Congo \#1H Project Area, Shelby County, Texas. Miscellaneous Reports of Investigations No. 543. Geo-Marine, Inc., Plano.

2013 Cultural Resources Survey of the Golden Flashes \#1H Project Area, Shelby County, Texas. Miscellaneous Reports of Investigations No. 579. Geo-Marine, Inc., Plano.

2013 Cultural Resources Survey of the New Horizons Y\#1H Well Pad, Panola County, Texas. Miscellaneous Reports of Investigations No. 583. GeoMarine, Inc., Plano. 
2013 Cultural Resources Damage Assessment: Site 41WD655, SASI Ranch \#3-5 Project Area, Wood County, Texas. Miscellaneous Reports of Investigations No. 558. Geo-Marine, Inc., Plano.

2015 Intensive Archeological Survey of US 175 from FM 804 to SH 155, Anderson and Henderson Counties, Texas. Archeological Studies Program Report No. 166. Environmental Affairs Division, Texas Department of Transportation, Austin.

2015 Cultural Resources Survey for the Proposed Texas Horse Park, Dallas County, Texas. Miscellaneous Reports of Investigations No. 573. Versar, Inc., Richardson, Texas.

2016 Cultural Resources Survey of the Tweed \#1H Project Area, Compartment 30, Sabine National Forest, Shelby County, Texas. Miscellaneous Reports of Investigations No. 612. Versar, Inc., Richardson, Texas.

Goodwin, R. C.

1991 A Cultural Resource Survey, Brown Bend Realignment and Slay Bend Reveyment, Red River Waterway, Arkansas. R. Christopher Goodwin \& Associates, Inc., New Orleans, Louisiana.

Goodwin, R. C., A. Markell, R. Draughon, Jr., S. B. Smith, J. Cohen, P. Heinrich, S. Hinks, and W. P. Athens

1995 Cultural Resources Survey at Loggy Bayou Mitigation Lands, Bossier Parish, Louisiana. R. Christopher Goodwin \& Associates, Inc., New Orleans, Louisiana.

Graham, M. and N. Murphy

2010 NAGPRA at 20: Museum Collections and Reconnections. Museum Anthropology 33(2):105-124.

Gramly, R. M. and S. Johnson

2007 The KaDoHa Project: A Caddoan Settlement at Murfreesboro, Arkansas. The Amateur Archaeologist 12(1):67-90.

Granberry, D. S.

1978 Mckenzie Mound. The Record 34(1):11-12.

1980 Mckenzie Mound Update. The Record 36(1):12-14.

1985 Eight C-14 Dates from McKenzie Mound Site, 41WD55. The Record 40(2):4-9. Dallas Archeological Society, Dallas.

1985 McKenzie Mound Status. The Record 41(1):21. 
1995 William T. McKenzie Mound. The Record 46(1):1-18. Dallas Archeological Society, Dallas.

Gray, J. W., J. W. Pye, and S. Bourget

2016 A Cultural Resources Survey for the Sabine River Authority of Texas Capital Improvements and Maintenance Projects in Sabine National Forest, Compartments 38, 102, 110, and 138, Sabine and Shelby Counties, Texas. Contract Publication Series 15-293. Cultural Resource Analysts, Inc., Shreveport.

Green, D. F.

19661964 Field Season at the Powell Mound Site. In Caddoan Area Field Reports, 1962-1964 Field Seasons, edited by H. A. Davis, pp. 21-25. University of Arkansas Museum, Fayetteville.

1986 A Second Season at the Powell Site, 3CL9. The Arkansas Archeologist 23/24:1-29.

1986 Brief Test Excavations at the Sheets Site (3CL30) and the Rock House Site (3CL31). The Arkansas Archeologist 23/ 24:30-42.

19861964 Investigations in DeGray Reservoir. The Arkansas Archeologist 23/24:43-65.

Green, M. M., C. Lintz, M. D. Freeman, A. Burkhalder, and T. K. Perttula 2011 Barksdale Air Force Base, Louisiana: National Register Evaluative Testing at Sites 16BO453, 16BO454, 16BO476, 16BO477, and 16BO531. Report of Investigations, No. 57. United State Air Force Air Combat Command Series. Geo-Marine, Inc., Plano.

Gregoire, L.

1972 Drawings of Three Vessels from Feature 32 at the Ferguson Site, 3HE63. The Arkansas Archeologist 13(1-2):34-37.

Gregory, H. F.

1966 Vessels from the Bison Site. Louisiana Studies 5(2):159-161.

1973 Eighteenth Century Caddoan Archaeology: A Study in Models and Interpretation. Ph.D. dissertation, Department of Anthropology, Southern Methodist University, Dallas.

1979 Archaeology of the Fort St. Jean Baptiste Replication Site, 16NA68. Williamson Museum, Northwestern State University, Natchitoches.

1980 The Doctor and Caddology: Dr. Clarence H. Webb's Contribution to Caddo Archaeology. Louisiana Archaeology 6:19-28. 
1980 A Continuity Model for Caddoan Adaptation on the Red River in Louisiana. Louisiana Archaeology 5:347-360.

1983 Los Adaes: The Archaeology of an Ethnic Enclave. Geoscience and Man 23:53-57.

2009 The Caddo and the Caddo Conference. Caddo Archeology Journal 19:1-2.

Gregory, H. F. and G. Avery

2007 American Indian Pottery from Historic Period Sites in North Louisiana. Journal of Northeast Texas Archaeology 26:33-76.

Gregory, H. F. and H. K. Curry

1977 Natchitoches Parish Cultural and Historical Resources: Prehistory. Louisiana Division of Archaeology, Baton Rouge.

n.d. Supplementary Excavations at the Robert Bison Site in Sabine Parish, Louisiana. Report on file at Northwestern State University, Natchitoches.

Gregory, H. F. and C. Pine

1976 Archaeological Architectural and Historical Assessment, Grand Bayou Project, Red River Parish, Louisiana. Louisiana Division of Archaeology, Baton Rouge.

Gregory, H. F. and C. H. Webb

1965 European Trade Beads from Six Sites in Natchitoches Parish, Louisiana. Florida Anthropologist 18(3):15-44.

Gregory, H. F., G. Avery, A. L. Lee, and J. C. Blaine

2004 Presidio Los Adaes: Spanish, French, and Caddoan Interaction on the Northern Frontier. Historical Archaeology 38(3):65-77.

Gregory, H. F., J. C. Blaine, and S. Morrison

1982 Presidio Nuestra Senora Del Pilar de los Adaes: Excavations 1981-1982. Williamson Museum, Northwestern State University, Natchitoches.

Gregory, H. F., J. C. Blaine, D. Scale, and K. Hart

1985 Excavations. Unit 227 Presidio Nuestra Senora del Pilar de los Adaes (16NA16). Williamson Museum, Northwestern State University, Natchitoches.

Gregory, H. F., H. K. Curry, and J. L. McCorkle, Jr.

1979 Natchitoches Parish Cultural and Historical Resources: History. Louisiana Division of Archaeology, Baton Rouge. 
Gregory, H. F., A. Lee, J. C. Blaine, D. Eschenfelder, and D. Raymond 1984 Excavations: Presidio de Nuestra Senora del Pilar de los Adaes. Williamson Museum, Northwestern State University, Natchitoches.

Gregory, H. F., J. Mathews, P. Mathews, and A. Robbins 1980 Presidio Nuestra Senora Del Pilar de los Adaes Excavations: 1979. Williamson Museum, Northwestern State University, Natchitoches.

Gregory, H. F., C. Pine, T. Jones, D. Pleasant, and J. Jones

1989 An Archaeological Survey of the Lower Dugdemona River, Winn Parish, Louisiana. Williamson Museum, Northwestern State University, Natchitoches.

1990 An Archaeological Survey of the Upper Dugdemona River, Bienville and Jackson Parishes, Louisiana. Williamson Museum, Northwestern State University, Natchitoches.

Gremillion, K. J.

2014 Goosefoot (Chenpodium). In New Lives for Ancient and Extinct Crops, edited by P. E. Minnis, pp. 44-64. University of Arizona Press, Tucson.

Griffin, J. B.

1952 An Interpretation of the Place of Spiro in Southeastern Archaeology. The Missouri Archaeologist 14:89-106.

1961 Relationships Between the Caddo Area and the Mississippi Valley. Bulletin of the Texas Archeological Society 31:27-37.

Griffin, J. B. and R. A. Yarnell

1963 A New Radiocarbon Date on Corn from the Davis Site, Cherokee County, Texas. American Antiquity 28(3):396-397.

Griffith, T. B., R. C. Fields, S. L. Katauskas, and A. E. Dase

2012 Archeological and Historical Resources Surveys of 2,144 Acres in the Proposed Marshall Mine, Harrison and Panola Counties, Texas. Reports of Investigations No. 163. Prewitt and Associates, Inc., Austin.

Griffith, T. B., K. W. Kibler, and D. K. Boyd

2010 National Register Testing at 41BQ285, Bosque County, Texas: FM 56 Bridge Replacement at the North Bosque River. Archeological Studies Program, Report No. 101. Texas Department of Transportation, Environmental Affairs Division, and Reports of Investigations No. 160, Prewitt and Associates, Inc., Austin.

Grimes, C. W.

1938 The Grand River Survey. Oklahoma Prehistorian 1(1):7-8. 
Groves, G. I.

1936 The North American Indian Relic Collectors' Association Report on the Great Temple Mound in Le Flore County, Oklahoma. North American Indian Collectors Association Bulletin 1(8):3-7, 9-10, 12, 15.

Guan, G. X., L. E. Raymer, C. V. Voorhies, and M. B. Reed

1994 An Archaeological Survey of 4,444 Acres of the Oden, Mena, and Poteau Districts in Arkansas and the Tiak and Kiamichi Districts in Oklahoma of the Ouachita National Forest. Technical Report No. 259. New South Associates, Stone Mountain, Georgia.

Guccione, M. J.

2008 Impact of the alluvial style on the geoarcheology of stream valleys. Geomorphology 101:378-401.

Guccione, M. J. and P. Hays

2008 Geomorphology, Sedimentology, and Vegetation History along the Red River Floodplain, Bowie County, Texas. In Integrated Cultural Resources Investigations for the Bowie County Levee Realignment Project, Bowie County, Texas and Little River County, Arkansas, by S. A. Sundermeyer, J. T. Penman, and T. K. Perttula, pp. 109-166. Miscellaneous Reports, Report of Investigations No. 29. LopezGarcia Group, Dallas.

Guccione, M. J., M. C. Sierzchula, R. H. Lafferty III, and D. Kelley 1998 Site Preservation along an Active Meandering and Avulsing River: The Red River, Arkansas. Geoarchaeology 13(5):475-500.

Guderjan, T. H.

1986 Big Rock: A Woodland and Caddoan Rock-Shelter in East Texas. Bulletin of the Texas Archeological Society 55:171-187.

1996 Big Rock Shelter. In The New Handbook of Texas, Vol. 1, edited by R. Tyler, pp. 535-536. Texas State Historical Association, Austin.

Guderjan, T. H., G. W. Rutenberg, M. O. Baldia, M. Irvine, P. A. Murray, L. M. Raab, and H. A. Smith

1981 Archaeological Investigations in the Forest Grove/Big Rock Areas, NorthCentral Texas. Archaeology Research Program, Southern Methodist University, Dallas.

Guendling, R. L.

1990 Cultural Resources Survey and Testing at Structures 16 and 17, South Fork of Ozan Creek Watershed, Hempstead County, Arkansas. Project Report No. 740. Arkansas Archeological Survey, Fayetteville. 
1993 A Cultural Resources Survey of the Norman Sewer Line Extensions, Montgomery County, Arkansas. Project Report No. 820. Arkansas Archeological Survey, Fayetteville.

1996 Test Excavations at the Faulkner Lake Sites: 3PU115, 3PUI63 and 3PU410, Pulaski County, Arkansas. Project Report No. 939. Arkansas Archeological Survey, Fayetteville.

2003 A Cultural Resources Survey of Selected Portions of the Ozone Water System, Johnson County, Arkansas. Sponsored Research Program Project No. 02-07. Arkansas Archeological Survey, Fayetteville.

2003 A Cultural Resources Survey of the Otter Creek Development Area, Pulaski County, Arkansas. Sponsored Research Program Project No. 0313. Arkansas Archeological Survey, Fayetteville.

2004 A Cultural Resources Survey of Selected Springdale Sewerline Extensions, Benton and Washington Counties, Arkansas. Final Report, Project 04-06. Submitted to McGoodwin Williams \& Yates, Fayetteville. Arkansas Archeological Survey, Fayetteville.

2005 Test Excavations at $3 B E 760$ and 3BE762 along the Springdale Sewerline Extensions, Benton and Washington Counties, Arkansas. Sponsored Research Program Report No. 05-02. Arkansas Archeological Survey, Fayetteville.

2008 (editor) Brown Bluff: Modern excavations and reanalysis of 1932 collections at a National Register Bluff Shelter (3WA10), Washington County, Arkansas. Project 896. Arkansas Archeological Survey, Fayetteville.

Guendling, R. L. and R. C. Mainfort, Jr.

2004 A Cultural Resources Survey of Selected Springdale Sewerline Extensions, Benton and Washington Counties, Arkansas. Sponsored Research Program Report No. 04-06. Arkansas Archeological Survey, Fayetteville.

Guendling, R. L. and J. J. Mintz

1989 A Cultural Resources Survey of the Norman Sewer Plant Relocation Site and Related Improvements, Montgomery County, Arkansas. Project Report No. 699. Arkansas Archeological Survey, Fayetteville.

Guendling, R. L., J. C. Dixon, S. L. Scott, and S. L. Dunavan 1994 The Couch Site Mitigation Excavations. Project Report No. 824. Arkansas Archeological Survey, Fayetteville. 
Gulf South Research Institute

1975 Red River Waterway Louisiana, Texas, Arkansas, and Oklahoma. Mississippi River to Shreveport, Louisiana, and Shreveport, Louisiana to Daingerfield, Texas. Design Memorandum No. 15, Analysis, Volume 5: Archaeology, History, and Culture. Final report on file, Louisiana Division of Archaeology, Baton Rouge.

Guilinger, E. L.

1971 The Archaeological Situation at the Copeland Site, a Fourche Maline Site in LeFlore County. Master's thesis, Department of Anthropology, University of Oklahoma, Norman.

Guy, J. A.

1988 A History of Archeological Research within the West Gulf Coastal Plain. Master's thesis, Department of Anthropology, The University of Texas at Austin.

1990 Previous Archeological Investigations. In The Archeology and Bioarcheology of the Gulf Coastal Plain, by D. A. Story, J. A Guy, B. A. Burnett, M. D. Freeman, J. C. Rose, D. G. Steele, B. W. Olive, and K. J. Reinhard, pp. 27-130. Research Series No. 38. 2 Vols. Arkansas Archeological Survey, Fayetteville.

Haag, W. G.

1965 Louisiana in North American Prehistory. Louisiana Studies 4:279-323.

Hackbarth, M. and L. M. Raab

1978 Summary Report of Archeological Resources Recorded in the Ouachita National Forest, Arkansas. Arkansas Archeological Survey, Fayetteville.

Hackenberger, S.

1976 Report of the Ten Percent Archeological Reconnaissance of Proposed McGee Creek Reservoir. Research Report No. 14. Archeological Research Associates, Tulsa.

Haikey, L. D.

1991 Cultural Resources Survey for Timber Sale Activity, Compartments 275 and 276, Kiamichi Ranger District, LeFlore County, Oklahoma. Ouachita Cultural Resources Report No. 2. USDA Forest Service, Ouachita National Forest, Hot Springs AR.

1992 Choctaw Ranger District, LeFlore County, Compartments 3, 59 and 63. Kiamichi Ranger District, USDA Forest Service, Ouachita National Forest, Hot Springs.

Haikey L. D., K. D. Coplen, and J. C. Smith 
2001 An Archeological Survey for Salvage Sale on Tornado Blowdown Lands, in Compartments 850, 858, 861, and 862 Mena Ranger District, Ouachita National Forest, Polk County, Arkansas. Ouachita Cultural Resources Report 204. Ouachita National Forest, Hot Springs.

Hall, R. L.

1951 The Late Prehistoric Occupation of Northeastern Oklahoma as Seen from the Smith Site. Master's thesis, Department of Anthropology, University of Wisconsin, Madison.

1954 Ck-44: A Bluff Shelter from Northeastern Oklahoma. Bulletin of the Oklahoma Anthropological Society 2:49-67.

Hamilton, D. L.

1997 Observations on Caddoan Burial Practices at the Sanders Site (41LR2). Bulletin of the Texas Archeological Society 68:115-134.

Hamilton, H. W.

1952 The Spiro Mound. The Missouri Archaeologist 14:17-88.

Hamilton, H. W., J. T. Hamilton, and E. F. Chapman

1974 Spiro Mound Copper. Memoirs No. 11. Missouri Archaeological Society, Columbia.

Hamilton, T. M.

1968 Early Indian Trade Guns, 1625-1775. Contributions No. 3. Museum of the Great Plains, Lawton.

Hammerstedt, S. W.

2012 An update on the geophysical survey at Spiro Mounds. Trowel Marks (The Oklahoma Anthropological Society Quarterly News) 4(3):9.

2012 An Update on Geophysical Survey at Spiro. Field Notes (Newsletter of the Arkansas Arheological Society) 369:11-12.

Hammerstedt, S. W. and J. Cox

2011 Animal Imagery on Two Artifacts from Eastern Oklahoma. Oklahoma Anthropological Society Bulletin 59:129-133.

Hammerstedt, S. W. and M. K. Galloway

2009 Archeological Survey of the Big Skin Bayou Area, Sequoyah County, Oklahoma. Archeological Resource Survey Report No. 59. Oklahoma Archeological Survey, Norman.

Hammerstedt, S. W., A. L. Regnier, and P. C. Livingood 
2010 Geophysical and Archaeological Investigations at the Clement Site, A Caddo Mound Complex in Southeastern Oklahoma. Southeastern Archaeology 29(2):279-291.

Hammerstedt, S. W., J. J. Lockhart, P. C. Livingood, T. Mulvihill, A. L. Regnier, G. Sabo III, and J. R. Samuelsen

2017 Multisensor Remote Sensing at Spiro: Discovering Intrasite Organization. In Archaeological Remote Sensing in North America: Innovative Techniques for Anthropological Applications, edited by D. P. McKinnon and B. S. Haley, pp. 11-27. University of Alabama Press, Tuscaloosa.

Hampton, $\mathrm{H}$. and G. Moore 1936 A Burial Site in Northeastern Red River County. Central Texas Archeologist 2:64-68.

Hanna, H., Jr.

1950 Three Burials from Mound 2, T. M. Sanders Site. The Record 8(4):16-19. Dallas Archeological Society, Dallas.

Hanvey, V. N.

2013 ARF Grant Funds AMS Date from Caddo Structure at 3SA295. Field Notes (Newsletter of the Arkansas Archeological Society) 374:3-6.

2014 Predictive Modeling of a Caddo Structure in the Ouachita Mountains, Montgomery County, Arkansas. Caddo Archeology Journal 24:43-52.

2014 Radiocarbon Dates for the Arkadelphia Canoe. Field Notes (Newsletter of the Arkansas Archeological Society) 379:3-4.

Hanvey, V. N., M. B. Trubitt, and J. J. Lockhart

2014 Investigating a Community in the Borderlands: Archeological Testing at Two Sites in the Saline River Valley, Arkansas. Henderson State University and the Arkansas Archeological Survey, Arkadelphia.

Harbour, R.

1999 Cultural Resources Survey Report 08009-08-634 for a Timber Sale Project in Compartment 1006, Oden Ranger District, Ouachita National Forest. Ouachita National Forest, Hot Springs.

2005 Cultural Resource Survey Report 08-09-07-497 Timber Harvest Surveys, Mena Ranger District, Ouachita National Forest. Ouachita National Forest, Hot Springs.

2005 Cultural Resource Reconnaissance Report No. 08-09-07-498, Mena Ranger District, Ouachita National Forest. Ouachita National Forest, Hot Springs. 
2005 Cultural Resource Survey Report 08-09-07-505 Timber Harvest Surveys, Mena Ranger District, Ouachita National Forest. Ouachita National Forest, Hot Springs.

Harcourt, J. P.

1990 A Cultural Resources Survey of the Arkla Energy Resources Inc., High Pressure Gasline from Cove to Bismarck, Polk, Howard, Pike, Clark, and Hot Spring Counties, Arkansas. Project Report No. 715e. Arkansas Archeological Survey, Fayetteville.

1990 A Cultural Resources Survey of a Proposed Arkla Natural Gas Line Near Emmet, Nevada County, Arkansas. Project Report No. 722. Arkansas Archeological Survey, Fayetteville.

1991 Test Excavations at the Terre Rouge Site (3NE93): A Multicomponent Midden Site in Nevada County, Arkansas. Project Report No. 725. Arkansas Archeological Survey, Fayetteville.

1992 Terre Rouge-After the Dig. Field Notes (Newsletter of the Arkansas Archeological Survey) 244:9.

1993 A Cultural Resources Inventory of the ARKL OM-1. Natural Gas Pipeline in Franklin and Washington Counties, Arkansas. Project Report No. 882. Arkansas Archeological Survey, Fayetteville.

1995 Additional Cultural Resource Investigations in the New Perspectives Research Stands of the Ouachita National Forest. The 13 Sites Project. Project Report No. 853. Arkansas Archeological Survey, Fayetteville.

Harden, P.

1976 Report of Survey of Brushy-Peaceable Creeks Watershed Impoundments 31, 32, 33, 34, 35, 36, and 37. Oklahoma Conservation Commission Archeological Laboratory, Norman.

1981 Excavations at Sliding Stab Shelter: Hunting and Gathering in the Ouachitas. Environmental Assessments, Inc., Pauls Valley, Oklahoma.

Harden, P. and D. Robinson

1975 A Descriptive Report of the Vanderpool Site, Ck-32, Cherokee County, Oklahoma. Bulletin of the Oklahoma Anthropological Society 23:91-168.

Hardey, J. and C. McCrocklin

1991 Preliminary Report on the Archeological Survey of Stormy Point. Caddoan Archeology Newsletter 2(3):16-21. 
Harmon, A. M. and J. C. Rose

1989 Bioarcheology of the Louisiana and Arkansas Study Area. In Archeology and Bioarcheology of the Lower Mississippi Valley and Trans-Mississippi South in Arkansas and Louisiana, by M. D. Jeter, G. I. Williams, J. C. Rose, and A. M. Harmon, pp. 323-354. Research Series No. 37. Arkansas Archeological Survey, Fayetteville.

Harrell, B. C., C. Sypniewski, A. DeCaro, and N. Linville 2016 National Register of Historic Places (NRHP) Eligibility Determinations for Previously Recorded Archaeological Sites at Wright Patman Lake, Bowie and Cass Counties, Texas. SEARCH, Jacksonville, Florida.

Harrington, M. R.

1920 Certain Caddo Sites in Arkansas. Indian Notes and Monographs, Miscellaneous Series No. 10. Museum of the American Indian, Heye Foundation, New York.

1924 The Ozark Bluff Dwellers. American Anthropologist 26(1):1-21.

1924 A Pot-Hunter's Paradise. Indian Notes and Monographs 1(2):84-90. Museum of the American Indian, Heye Foundation, New York.

1960 The Ozark Bluff-Dwellers. Indian Notes and Monographs No. 12. Museum of the American Indian, Heye Foundation, New York.

Harris, R.

2003 Prescribed Burn for Compartment 1615, Womble Ranger District. 08-0910-508. Ouachita National Forest, Hot Springs.

Harris, R. K.

1942 The Gilkey Hill Pottery Site. The Record 3(9):48-53. Dallas Archeological Society, Dallas.

1946 An Interesting Copper Article from Garrett's Bluff. The Record 5(1):7. Dallas Archeological Society, Dallas.

1948 Preliminary Report on the Alto Focus Site in Kaufman County. The Record 7(4):13-15. Dallas Archeological Society, Dallas.

1948 A Pottery Site near Farmersville. The Record 6(10):38-45. Dallas Archeological Society, Dallas.

1951 An Unusual Stone Pipe from the Sam Kaufman Site. The Record 10(2):6. Dallas Archeological Society, Dallas. 
1951 Two Mussel Shell Hoes from Site 19A1-2. The Record 9(4):20. Dallas Archeological Society, Dallas.

1953 The Sam Kaufman Site, Red River County, Texas. Bulletin of the Texas Archeological and Paleontological Society 24:43-68.

1953 Two Recent Trips to Sites in Fannin and Lamar Counties. The Record 11(5):19-20. Dallas Archeological Society, Dallas.

1955 A Flexed Burial Site 19C5-15, Delta County, Texas. The Record 14(2):810. Dallas Archeological Society, Dallas.

Harris, R. K. and I. M. Harris

1962 Another Marker on the Trail of the Norteno: A Preliminary Report on the Gilbert Site. The Record 17(1):2-9. Dallas Archeological Society, Dallas.

1980 Distribution of Natchitoches Engraved Ceramics. Louisiana Archaeology 6:223-230.

Harris, R. K. and R. Hatzenbuehler

1953 A Flexed Burial, Delta County, Texas. The Record 11(4). Dallas Archeological Society, Dallas.

Harris, R. K. and L. Wilson

1956 Burial 17, The Sam Kaufman Site (19B3-2). The Record 14(4):17-22.

Dallas Archeological Society, Dallas.

Harris, R. K., I. M. Harris, and P. Miroir

1980 The Atlanta State Park Site in Northeastern Texas. Louisiana Archaeology 6:231-239.

Harris, R. K., I. M. Harris, J. C. Blaine, and J. Blaine

1965 A Preliminary Archeological and Documentary Study of the Womack Site, Lamar County, Texas. Bulletin of the Texas Archeological Society 36:287365.

Harris, R. K., Mr. J. Perkins, and Mrs. J. Perkins

1954 Burials 12,13, 14, and 15, The Sam Kaufman Site 19B32. The Record 13(1):2-8. Dallas Archeological Society, Dallas.

Hart, J. P.

1982 An Analysis of the Aboriginal Ceramics from the Washington Square Mound Site, Nacogdoches County, Texas. Master's thesis, Department of Anthropology, Northeast Louisiana University, Monroe. 
2014 An Analysis of the Aboriginal Ceramics from the Washington Square Mound Site, Nacogdoches County, Texas. Stephen F. Austin State University Press, Nacogdoches.

Hart, J. P., and J. E. Corbin

1984 An Analysis of the Aboriginal Ceramics from the Washington Square Mound Site, Nacogdoches County, Texas. Papers in Anthropology No. 6. Stephen E Austin State University, Nacogdoches.

Hart, J. P. and T. K. Perttula

2010 The Washington Square Mound Site and a Southeastern Ceremonial Complex Style Zone among the Caddo of Northeastern Texas. Midcontinental Journal of Archaeology 35(2):199-228.

Hartley, J. and R. Barrett

1996 Archaeological Test Excavations at the Leader Creek Site (34CO114): A Woodland Assemblage in Coal County, Oklahoma. Reports in Highway Archaeology No. 13. Oklahoma Department of Transportation, Norman.

Harty, J.

1997 The Lindsey Site: A Mound Complex on Big Corney Bayou in Union Parish, Louisiana. Louisiana Archaeology 22:125-142.

2005 A Description of Ceramic Sherds from the James Jones Site (16UN81). Louisiana Archaeology 26:62-70.

Harvey, M. Z.

2014 Crenshaw (3MI6) Bioarcheology Notes: Provenience Descriptions. The Arkansas Archeologist 52:65-74.

Harvey, M. Z., B. Farley, and J. C. Rose

2014 Crenshaw (3MI6) Bioarcheology Notes: Burial Descriptions. The Arkansas Archeologist 52:75-208.

Haskins, P. and M. Walters

2001 Archaeological Investigations of an Oil Well Pad Disturbance at the Tom Moore Site (41PN149), Panola County. Journal of Northeast Texas Archaeology 14:37-61.

Hatfield, V., K. W. Kibler, and R. C. Fields

2008 Interim Report on Eligibility Testing at 41TT6, 41TT846, 41TT847, 41TT851, 41TT852, 41TT853, 41TT854, 41TT858, 41TT862, 41TT865, and 41TT866, U.S. Highway 271 Mount Pleasant Relief Route, Titus County, Texas. Prewitt and Associates, Inc., Austin.

Hathcock, R. 
1974 Caddo Effigy Pottery from Arkansas. Central States Archaeological Journal 2l (3):112-115.

Hatzenbuehler, R.

1946 Some Artifacts from Hopkins County, East Texas. The Record 5(1):3-6. Dallas Archeological Society, Dallas.

1949 An Indian Burial, Hopkins County, Texas. The Record 7(10):34-36. Dallas Archeological Society, Dallas.

1950 Preliminary Report on Site 19C3-5. The Record 8(6):24-26. Dallas Archeological Society, Dallas.

1950 Preliminary Report on Site 19C9-1. The Record 9(1):23. Dallas Archeological Society, Dallas.

1951 A Preliminary Report on Site 19C3-1 in Hopkins County, Texas. The Record 9(4):16-17. Dallas Archeological Society, Dallas.

1953 A Flexed Burial, Delta County, Texas. The Record 11(4):16-17. Dallas Archeological Society, Dallas.

Haury, C. E.

1986 The Prehistory and Paleoenvironment of Hominy Creek Valley: 1982-1983 Field Season, Excavations at Copperhead Cave (34OS85) and Archaeological Overview Investigations in Hominy Creek Valley. Contributions in Archaeology 15. Laboratory of Archaeology, The University of Tulsa, Tulsa, Oklahoma.

Hawley, M. F.

2006 Introduction to Plains Archaeology's Past. Plains Anthropologist 51(200):487-520.

Hayes, D. R., D. C. Roper, and J. Schuldenrein

1985 Archeological Investigations at Fort Gibson Lake, Mayes, Cherokee, and Wagoner Counties, Oklahoma. Gilbert/Commonwealth Inc., Englewood, Colorado.

Hayner, E. W.

1955 Another Puebloan Trade Sherd in East Texas. Bulletin of the Texas Archeological Society 26:244-248.

1957 Some Pottery Bearing Campsites in and Around Caddo Lake. Oklahoma Anthropological Society Newsletter 5(8):4-8.

Hays, J. D. 
1982 An Assessment of Mitigative Action by Texas Oil and Gas Corporation on Five Archaeological Sites in Southeastern Oklahoma. Archaeological Research Associates, Tulsa, Oklahoma.

1984 Cultural Resources Survey Within the Tiak Ranger District (McCurtain County, Oklahoma) of the Ouachita National Forest. Heartfield, Price and Greene, Inc., Monroe, Louisiana.

1985 Data Recovery at the Tucker's Knob Site (34Lt35). Heartfield, Price and Greene, Inc., Monroe, Louisiana.

Heartfield, L.

1977 Archeological Assessment of the Ouachita River Basin, Arkansas and Louisiana. Heartfield, Price, and Greene, Inc., Monroe, Louisiana.

1983 A Cultural Resources Survey of the Dolet Hills Lignite Project, DeSoto Parish, Louisiana. Heartfield, Price, and Greene, Inc., Monroe, Louisiana.

Heartfield, Price, and Greene, Inc.

1979 A Cultural Resources Survey of the Oxbow Lignite Prospect. Phase II. Heartfield, Price, and Greene, Inc., Monroe, Louisiana.

1979 Phase I of the Cultural Resources Survey of the Chicot-Pollux Lignite Prospect. Heartfield, Price, and Greene, Inc., Monroe, Louisiana.

1980 Phase III of the Cultural Resources Survey in the Castor Bayou Lignite Prospect, Northwestern Louisiana. Heartfield, Price, and Greene, Inc., Monroe, Louisiana.

1980 A Cultural Resources Survey of Four Proposed Possible Re-Alignments of the North-South Expressway in the Vicinity of the Proposed Oxbow Lignite Field. Heartfield, Price, and Greene, Inc., Monroe, Louisiana.

1981 A Preliminary Cultural Resources Overview of the Yantis Project, Northeast Texas. Heartfield, Price, and Greene, Inc., Monroe, Louisiana.

1981 Yantis Project. Cultural Resources Report No. 2. Heartfield, Price, and Greene, Inc., Monroe, Louisiana.

1981 Cultural Resources Investigations of a Proposed Parking and Picnic Table Area, Highway 27 Recreation Area, Lake Ouachita, Arkansas. Heartfield, Price, and Greene, Inc., Monroe, Louisiana.

1982 A Cultural Resources Survey of High Site Probability Locations which will be Affected by Proposed Levee Construction within Angelina Farms, Red 
River County, Texas. Heartfield, Price, and Greene, Inc., Monroe, Louisiana.

1982 A Cultural Resources Survey of Portions of Harts Bluff Ranch in Connection with Corps of Engineers Permit No. SWF-81-TITUS- 396. Heartfield, Price, and Greene, Inc., Monroe, Louisiana.

1982 Report of Cultural Resources Associated with Construction of the Ozark Natural Gas Pipeline in Eastern Oklahoma. Heartfield, Price, and Greene, Inc., Monroe, Louisiana.

1982 Cultural Resources Survey of the First Five Year Mining Block of the Chicot-Pollux Project. Heartfield, Price, and Greene, Inc., Monroe.

1983 Cultural Resources Survey in the Yantis Lignite Project Area. Heartfield, Price, and Greene, Inc., Monroe, Louisiana.

1983 Cultural Resources Investigations for the Castor Bayou Lignite Project: 1978-1982. Heartfield, Price, and Greene, Inc., Monroe, Louisiana.

1984 An Intensive Cultural Resources Survey of a 2,900 Acre Tract, Martin Lake Area D, Rusk County, Texas. Heartfield, Price, and Greene, Inc., Monroe, Louisiana.

1985 Data Recovery at Archeological Site 16NA37 (Montrose Site), Natchitoches Parish, Louisiana. Heartfield, Price, and Greene, Inc., Monroe.

1988 Data Recovery at 41HS74, Harrison County, Texas. Heartfield, Price, and Greene, Inc., Monroe.

Heartfield, L., T. Dieste, W. E. Moore, E. L. Beene, and G. L. Stringer 1984 An Archeological Overview and Management Plan for the Louisiana Army Ammunition Plant, Bossier and Webster Parishes, Louisiana. DARCOM Report No. 6, submitted to the National Park Service, U.S. Deparment of the Interior, by Woodward-Clyde Consultants, Walnut Creek, California.

Heartfield, L., K. Hudson, G. R. D. Price, S. Mitcham, H. E. Jackson, and G. S. Greene

1978 A Cultural Resource Survey and Evaluation of the Opelousas to Shreveport Portion of the Proposed North-South Expressway, Phases I and II. 3 Vols. Heartfield, Price, and Greene, Inc., Monroe.

Heinrich, P. V.

1987 Lithic Resources of Western Louisiana. Louisiana Archaeology 11:165190. 
Hemmings, E. T.

1980 Spirit Lake Site (3LA83): Results of the Field Phase and Initial Assessment of Significance. Project Report No. 339. Arkansas Archeological Survey, Fayetteville.

1982 Spirit Lake (3LA83): Test Excavations in a Late Caddo Site on the Red River. In Contributions to the Archeology of the Great Bend Region, edited by F. F. Schambach and F. Rackerby, pp. 55-89. Research Series No. 22. Arkansas Archeological Survey, Fayetteville.

Henderson, J.

1979 The Mothershed Spring Site. Publications in Archaeology Report No. 12. Texas State Department of Highways, Austin.

1982 Faunal Analysis. In The Deshazo Site, Nacogdoches County, Texas, Volume 1, edited by D. A. Story, pp. 131-157. Texas Antiquities Permit Series No. 7. Texas Antiquities Committee, Austin.

Henry, D. O.

1977 The Prehistory of the Little Caney River: 1976 Field Season. Contributions in Archaeology No. 1. Laboratory of Archaeology, The University of Tulsa, Tulsa.

1977 Prehistory and Paleoenvironment of Hominy Creek Valley. Contributions in Archaeology No. 2. Laboratory of Archaeology, The University of Tulsa.

1977 The Prehistory and Paleoenvironment of Birch Creek Valley. Contributions in Archaeology No. 3. Laboratory of Archaeology, The University of Tulsa.

1978 The Prehistory and Paleoenvironment of Hominy Creek Valley: 1977 Field Season. Contributions in Archaeology No. 4. Laboratory of Archaeology, The University of Tulsa.

1978 Big Hawk Shelter in Northeastern Oklahoma: Environmental, Economic, and Cultural Changes. Journal of Field Archaeology 5(3):269-287.

1979 Late Prehistoric Occupations in Northeastern Oklahoma. Current Anthropology 20:236-237.

1980 The Prehistory and Paleoenvironment of Hominy Creek Valley: 1978 Field Season. Contributions in Archaeology No. 6. Laboratory of Archaeology, The University of Tulsa, Tulsa. 
1982 The Prehistory and Paleoenvironment of Hominy Creek Valley: 1979 Field Season. Contributions in Archaeology No. 11. Laboratory of Archaeology, The University of Tulsa, Tulsa.

1998 The Area in the Vicinity of Tulsa, Oklahoma During the Late Holocene. Bulletin of the Oklahoma Anthropological Society 47:67-81.

1999 A Cultural Resource Survey of Designated Segments of a Proposed Route of an AT\&T Fiber Optic Line, Ft. Smith-Gateway, Arkansas. Donald O. Henry, Tulsa.

Henry, D. O., B. H. Butler, and S. A. Hall

1979 The Late Prehistoric Human Ecology of Birch Creek, Northeastern Oklahoma. Plains Anthropologist 24(85):207-238.

Herrington, L.

1979 Lake Bob Sandlin: A Case Study of the Mitigation Process in a Reservoir Area. Technical Report No. 32. Texas Antiquities Committee, Austin.

Hester, T. R.

2013 Looking Toward the 2013 TAS Field School: The View from Eagle Bluff. Texas Archeology 57(1):4-6.

Hicks, J.

1988 Cultural Resource Reconnaissance Report No. 08-09-07-46, Mena Ranger District, Ouachita National Forest. Ouachita National Forest, Hot Springs.

1988 Cultural Resource Reconnaissance Report No. 08-09-07-56, Mena Ranger District, Ouachita National Forest. Ouachita National Forest, Hot Springs.

Higgins, D. P. and M. D. Jeter

2012 A Prescient 1880 Study of "The Mound-Builders of Arkansas." The Arkansas Archeologist 50:1-24.

Highley, C. L. and D. Lenefeld

1977 Preliminary Investigations at the Wolf Site, Blanco County, Texas. La Tierra 4(4):16-19.

Hill, W. G. and J. E. Gilliland

2008 The Sorter's Bluff Point: An Uncommon Point Type Recovered from the Copperhead Site in Northwest Arkansas. The Arkansas Archeologist 46:16.

Hilliard, J. E. 
2001 Excavations at Spring Valley Road Shelter (3BE630), Benton County, Arkansas. The Arkansas Archeologist 41:29-53.

2001 Volunteers are Getting the Job Done at Benton County Site. Field Notes (Newsletter of the Arkansas Archeological Society) 298:13.

2003 The Harlan Phase. Field Notes (Newsletter of the Arkansas Archeological Society) 311:9-13.

Hilliard, J. E., G. J. Fritz, and E. B. Cooper

2004 The Archeology of Rock Art at the Narrows Shelter, Crawford County, Arkansas. Research Report No. 31. Arkansas Archeological Survey, Fayetteville.

Hindman, S. E.

1932 Materials used in the Manufacture of East Texas Pottery. Master's thesis, Department of Anthropology, The University of Texas at Austin.

Hinkle, K. A.

1988 A Cultural Resources Survey of a Site-Free Corridor Around the Garrard \#1 Site (3C08) on Arkla Line S, Columbia County, Arkansas. Project Report No. 668. Arkansas Archeological Survey, Fayetteville.

1988 A Cultural Resources Survey of the Malvern to Benton Arkla Line A, Hot Spring and Saline Counties, Arkansas. Project Report No. 676. Arkansas Archeological Survey, Fayetteville.

Hinks, S., M. Marek, P. V. Heinrich, R. Draughon, J. A. Cohen, and W. P. Athens 1993 Cultural Resources Survey at Red River Below Denison Dam, Levee Rehabilitation/Restoration, Item 1, Miller County, Arkansas. R Christopher Goodwin \& Associates, Inc., New Orleans.

Hinks, S. J., R. R. Robinson, P. V. Heinrich, K. M. Lombardi, J. A. Belfast, and M. $T$. Fuess

2010 Phase I Archaeological Survey, East-West Corridor, Winfield Road Extension, Bossier Parish, Louisiana. Michael Baker Jr., Inc., Little Rock.

Hinks, S., S. B. Smith, P. V. Heinrich, A. Saltus, Jr., and W. E. Athens 1994 Survey and Testing of Eight Items on the Red River in Pools 3 and 5, Red River Waterway, Louisiana. R Christopher Goodwin \& Associates, Inc., New Orleans.

Hodges, Mrs. T. L.

1957 The Cahinnio Caddo: A Contact Unit in the Eastern Margin of the "Caddo Area." Bulletin of the Texas Archeological Society 28:190-197. 
Hodges, T. L. and Mrs. T. L. Hodges

1943 The Watermelon Island Site in Arkansas. Bulletin of the Texas Archeological and Paleontological Society 15:66-79.

1945 Suggestions for the Identification of Certain Mid-Ouachita Pottery as Cahinnio Caddo. Bulletin of the Texas Archeological and Paleontological Society 16:98-116.

Hoffman, K. L.

1992 A Cultural Resources Survey of the Proposed Wastewater Treatment Improvements in Mineral Springs, Howard County, Arkansas. Project Report No. 803. Arkansas Archeological Survey, Fayetteville.

Hoffman, M. P.

1967 Ceramic Pipe Style Chronology Along the Red River Drainage in Southwestern Arkansas. The Arkansas Archeologist 8(1):4-14.

1967 Test Excavations in the White Cliffs Site and the Bell Site, Millwood Reservoir, Southwest Arkansas. Report prepared for the National Park Service, Southeast Region, by the University of Arkansas Museum, Fayetteville, Arkansas.

1969 Prehistoric Developments in Southwestern Arkansas. The Arkansas Archeologist 10(1-3):36-49.

1970 Archaeological and Historical Assessment of the Red River Basin in Arkansas. In Archeological and Historical Resources of the Red River Basin: Louisiana, Texas, Oklahoma, Arkansas, edited by H. A. Davis, pp. 135-194. Research Series No. 1. Arkansas Archeological Survey, Fayetteville.

1970 Three Sites in Millwood Reservoir: The Hutt Site, The Stark Site, and the Beard Lake Site, Arkansas. Research Series No. 2. Arkansas Archeological Survey, Fayetteville.

1971 A Partial Archeological Sequence for the Little River Region, Arkansas. Ph.D. dissertation, Department of Anthropology, Harvard University, Cambridge.

1983 Changing Mortuary Patterns in the Little River Region, Arkansas. In Southeastern Natives and Their Pasts, edited by D. G. Wyckoff and J. L. Hofman, pp. 163-182. Studies in Oklahoma's Past No. 11. Oklahoma Archeological Survey, Norman. 
1987 Who's Wearing the White Hats? The Arkansas Act to Prohibit Burial Desecration and its Implications for Caddoan Archaeology. Newsletter of the Southeastern Archaeological Conference 29(2):22-28.

Hoffman, M. J.

1978 Conservation Systems for the Spiro Textiles. Master's thesis, Department of Home Economics, University of Arkansas, Fayetteville.

Hofman, J. L.

1975 Archaeology at the Easton Site (Lf-213), LeFlore County, Oklahoma. Papers in Highway Archaeology No. 1. Oklahoma Highway Archaeological Survey, Norman.

1975 Bone Fleshers in Oklahoma. Bulletin of the Oklahoma Anthropological Society 23:169-175.

1976 A Double-Bitted Axe from Rogers County. Oklahoma Anthropological Society Newsletter 24(4):4-6.

1976 A Statement Concerning the Cultural Deposit at Archeological Site At80 and its Interpretive Potential. Manuscript on file, Oklahoma Conservation Commission Archeological Laboratory, Norman.

1977 A Review of Spiro Mound Copper. Oklahoma Anthropological Society Newsletter 25(3):4-6.

1977 Bibliography of Spiro Archaeology. Oklahoma Anthropological Society Newsletter 25(4):6-11.

1977 A Caddoan Pipe from the Shawver Site on the Canadian River in Western Oklahoma. Oklahoma Anthropological Society Newsletter 25(7):7-10.

1977 A Report on Preliminary Archeological Investigations at the Estep Shelter; Atoka County, Southeast Oklahoma. Archeological Research Report No.

2. Oklahoma Conservation Commission, Oklahoma City.

Hofman, J. L., L. Neal, J. T. Penman, T. Prewitt, R. S. Saunders, C. S. Wallis, Jr., and D. G. Wyckoff

1974 Reports of the ARKLA Salvage Project. Contract Archaeology Series No. 1. Oklahoma Archeological Survey, University of Oklahoma, Norman.

Hokanson, J. and K. Fariello

2006 A Cultural Resource Inventory of Approximately 15 Miles of Roads at Wister Lake, LeFlore County, Oklahoma. Engineering-Envionmental Management, Inc., Englewood, Colorado. 
Holmes, M. A.

1983 Scenes from Spiro Life: An Art Exhibit of Spiro Prehistory as Interpreted by Donald R. Johnson. Oklahoma Humanities Committee, Oklahoma Archeological Survey, University of Oklahoma, Norman, and Emporia State University.

Holmes, M. A. and M. Hill

1976 The Spiro Mounds Site. Prehistoric People of Oklahoma No. 2. Stovall Museum and the Oklahoma Archeological Survey, Norman.

Homburg, J.

1981 A Cultural Resources Survey of the Proposed Trans Anadarko Pipeline System, Texas, Oklahoma, Arkansas, Louisiana, Volumes 1 and 2. Report of Investigations No. 37. New World Research, Inc., Pollock, Louisiana.

Hooper, R. and J. Nance

1998 Report on Test Excavations at the Hood Site, 3HE54, Hempstead County, Arkansas. The Arkansas Archeologist 37:55-61.

Horizon Environmental Services, Inc.

1993 Cultural Resources of the Proposed Lake Gilmer Project, Upshur County, Texas. Horizon Environmental Services, Inc., Austin.

Horton, E.

2010 The Ties that Bind: Traditions and Fiber Use in the Ozark Plateau. Ph.D. dissertation, Washington University in St. Louis.

Horton, E. and G. Sabo III

2011 Spiro Perishable Project Makes Exciting New Discovery. Field Notes (Newsletter of the Arkansas Archeological Society) 358:9-13.

Houk, B. A. and B. S. Young

2001 Cultural Resources Survey of the KPP Supply Company Project, Pittsburg County, Oklahoma. SWCA, Inc. Cultural Resource Report No. 01-264, Austin.

House, J. H.

1972 Archaeological Salvage in the Basin of Lake Rodemacher, Rapides Parish, Louisiana. Final Report on file, Division of Archaeology and Historic Preservation, Department of Culture, Recreation and Tourism, Baton Rouge.

1978 Flat-based Shell-tempered Pottery in the Ozarks: Preliminary Discussion. The Arkansas Archeologist 19:44-49.

House, J. H., with contributions by G. J. Fritz and K. Murray 
1997 Time, People and Material Culture at the Kuykendall Brake Archaeological Site in Pulaski County, Arkansas. Internet version published at http://www.uark.edu/campus-resources/archinfo/kuykend.html.

Housewright, R.

1940 A Multiple Burial in Lamar County. The Record 2(8):37-39. Dallas Archeological Society, Dallas.

1946 A Turquoise Bead Necklace. The Record 5(2):9-10. Dallas Archeological Society, Dallas.

Howard, L. E.

1940 Preliminary Report on Cherokee County Archaeology. Society for American Archaeology Notebook 1:107-108.

1940 Preliminary Report on Cherokee County, Oklahoma Archaeology. The Oklahoma Prehistorian 3(1):2-11.

1941 Quarterly Field Report (Third Quarter, 1941), LeFlore County Archaeological Project. Manuscript on file at the Oklahoma Museum of Natural History, University of Oklahoma, Norman.

2001 Preliminary Report on Cherokee County, Oklahoma Archaeology. Caddo Archeology Journal 12(1):37-47.

Howard, M. (editor)

1996 Archeological Survey of Tyler State Park, Smith County, Texas. Public Lands Division, Cultural Resources Program, Texas Parks and Wildlife Department, Austin.

Hoyt, S. D., R. Rogers, E. Skokan, and W. P. Glander

1994 Cultural Resources Survey of the Proposed Monticello I Area Surface Mine, Titus County, Texas. Document No. 910438. Espey, Huston \& Associates, Inc., Austin.

Hrdlicka, A.

1912 Report on Skeletal Remains from a Mound on Haley Place, Near Red River, Miller County, Arkansas. Journal of the Academy of Natural Sciences of Philadelphia 14(4):639-640.

Hsu, D. P.

1969 Appraisal of the Archeological Resources of Titus County Reservoir. Archeological Survey Report No. 4. Texas State Building Commission, Austin.

Hsu, D. P, J. V. Scisenti, and S. A. Skinner 
1969 Appraisal of the Archeological Resources of Big Cypress (Franklin County) Reservoir. Archeological Survey Report No. 3. Texas State Building Commission, Austin.

Hubbard, R. A.

1991 An Archeological Reconnaissance and Survey of Proposed Sewerage System Improvements at the City of Longview, Gregg and Harrison Counties, Texas, State Revolving Fund Project No. 3089-001. Texas Water Development Board, Austin.

Hubbard, V.

1998 Lake Sam Rayburn Archaeological Site Inventory and Monitoring Project. Journal of Northeast Texas Archaeology 11:39-45.

Huddleston, V. L.

1943 Indians in Clark County. Arkansas Historical Quarterly 2(2):110-115.

Hudler, D., J. Jarvis, and T. Griffith

2006 A Partial Magnetometer Survey of the Archaeological Conservancy's Portion of the A. C. Saunders Site (41AN19). Texas Archeological Research Laboratory, The University of Texas at Austin.

Huff, M. E., Jr.

1960 Burial 18, The Sam Kaufman Site. The Record 15(1):24. Dallas Archeological Society, Dallas.

Hughes, D. T.

1976 The Bible Sites; Number 1 and Number 3, McCurtain County, Oklahoma. Research Report No. 1. Oklahoma Conservation Commission, Oklahoma City.

1976 The Archaeological Resources to be Affected by the Proposed Construction of Impoundment \#20 of the Lower Clear Boggy Creek Watershed Project. Manuscript on file, Oklahoma Conservation Commission Archeological Laboratory, Norman.

1977 Archeological Testing in Atoka County, Oklahoma: Archeological Sites 34At-160, 34At-163, and 34 At-175. Archeological Research Report No. 4. Oklahoma Conservation Commission, Oklahoma City.

1978 The Glasscock Site, 34Ps-96, and Two Other Sites in Pittsburg County. Archeological Research Report No. 5. Oklahoma Conservation Commission, Oklahoma City.

Hughes, D. T. and A. A. Hughes-Jones 
1987 Investigations of Archaeological Sites 34Lf534 and 34Lf537. Techrad, Inc., Oklahoma City.

Hughes, J. T.

1968 Prehistory of the Caddoan-Speaking Tribes. Ph.D. dissertation, Department of Anthropology, Columbia University, New York.

1974 Prehistory of the Caddoan Speaking Tribes. In Caddoan Indians, Volume III, pp. 9-411. Garland Publishing, New York.

Hughes, M.

2000 Salvaging a Site in Saline County. Field Notes (Newsletter of the Arkansas Archeological Society) 292:6.

Hughes, R. E., M. Kay, and T. J. Green

2002 Geochemical and Microwear Analysis of an Obsidian Artifact from the Brown Bluff Site (3WA10), Arkansas. Plains Anthropologist 47:73-76.

Hughes-Jones, A. and D. T. Hughes

1989 Archeological and Cultural Resource Investigations for Proposed Work Plan in Adair, Cherokee, Wagoner, and Muskogee Counties. David T. Hughes, Consulting Archeologist, Norman, Oklahoma.

Hunt, S. M. and G. Borrego

2002 Cultural Resources Survey of 17 Proposed Timber-Cutting Tracts at Wright Patman Lake, Bowie and Cass Counties, and Lake O' the Pines, Marion, Morris, and Upshur Counties, Texas. Miscellaneous Reports of Investigations No. 236. Geo-Marine, Inc., Plano.

Hunt, S. M., T. Everette, and G. Borrego

2002 Cultural Resources Survey of 1,664 Acres within Ten Proposed TimberCutting Tracts at Wright Patman Lake, Bowie and Cass Counties, and Lake O' the Pines, Marion and Upshur Counties, Texas. Miscellaneous Reports of Investigations No. 242. Geo-Marine, Inc., Plano.

Hunt, S. M., F. B. Largent, Jr., and M. B. Cliff

1996 Cultural Resources Evaluation of the Pilgrim's Pride Property South of Big Cypress Creek, Camp County, Texas. Miscellaneous Report of Investigations No. 118. Geo-Marine, Inc., Plano.

Hunt, S. M., D. Pleasant, and M. B. Cliff

1995 Cultural Resources Survey of 550 Acres at Lake O' the Pines, Marion County, Texas. Miscellaneous Report of Investigations No. 103. GeoMarine, Inc., Plano.

Hunter, D. G. 
2005 Cultural Resources Investigations for the Proposed CenterPoint Energy Gas Transmission's 12" FT-2 Replacement and Extension Project, Webster and Bienville Parishes, Louisiana. Coastal Environments, Inc., Baton Rouge.

Hunter, D. G., D. B. Kelley, A. R. Saltus, and L. L. Harkins

1992 Archaeological Investigations at Lock and Dam No. 5, Red River Waterway Louisiana. Coastal Environments, Inc., Baton Rouge.

Hunter, D. G., C. E. Pearson, J. LeBoeuf, and D. B. Kelley 2002 Cultural Resources Evaluations of the T.C. Bearden (16NA494), Ramblin Wreck (16NA495), and Charles Webb (16RR86) Archaeological Sites, Located Along Red River in Natchitoches and Red River Parishes, Louisiana. Coastal Environments, Inc., Baton Rouge.

Hyatt, R. D. and K. Doehner

1975 Archaeological Research at Cooper Reservoir, Northeast Texas, 1973. Contributions in Anthropology No. 15. Department of Anthropology, Southern Methodist University, Dallas.

Hyatt, R. D. and S. A Skinner

1971 Archaeological Resources of the Cooper Reservoir, Texas. Department of Anthropology, Southern Methodist University, Dallas.

Hyatt, R. D., B. H. Butler, and H. P. Mosca, III

1974 Archaeological Research at Cooper Lake 1970-1972. Contributions in Anthropology No. 12. Department of Anthropology, Southern Methodist University, Dallas.

Im, H. J.

1975 An Analysis of the G. E. Arnold Survey of East Texas. Master's thesis, Department of Anthropology, The University of Texas at Austin.

Ippolito, J.

1983 A Cultural Resource Overview of the National Forests in Texas. USDA, National Forests and Grasslands in Texas, Lufkin.

Irvine, M.

1979 Ceramics from the Williams I Site (34Lf-24): A Preliminary Analysis. Oklahoma Anthropological Society Newsletter 27(9):5-12.

1980 Ceramic Analysis from the Williams I Site, 34LF-24, LeFlore County, Oklahoma. Master's thesis, Department of Anthropology, University of Oklahoma, Norman. 
1983 An Analysis of the Prehistoric Ceramics from the Richland-Chambers Creek Dam and Reservoir Project Area, Navarro and Freestone Counties, Texas. Bulletin of the Texas Archeological Society 53:185-197.

Israel, S.

1969 Reexamination of the Cookson Site and Prehistory of Tenkiller Locale in Northeastern Oklahoma. Master's thesis, Department of Anthropology, University of Oklahoma, Norman.

1979 Re-Examination of the Cookson Site. Studies in Oklahoma's Past No. 4. Oklahoma Archeological Survey, Norman.

Jackson, A. T.

1930 Examination of a Burial Site, Richard Watson Farm, in Morris County, Texas. MS on file, Texas Archeological Research Laboratory, The University of Texas at Austin.

1930 Excavation of a Burial Site, R. L. Cason Farm, Morris County, Texas. MS on file, Texas Archeological Research Laboratory, The University of Texas at Austin.

1930 Excavation of a Burial Site, Joe Justiss Farm, Morris County, Texas. MS on file, Texas Archeological Research Laboratory, The University of Texas at Austin.

1930 Exploration of a Burial Site on R. L. Jaggers Farm, Franklin County, Texas. MS on file, Texas Archeological Research Laboratory, The University of Texas at Austin.

1930 Notes on Field Work, Minnie Garrison Farm, Wood County, Texas. MS on file, Texas Archeological Research Laboratory, The University of Texas at Austin.

1931 Field Notes, Excavations in Anderson County, Texas, 13 October 1931 to 12 November 1931. MS on file, Texas Archeological Research Laboratory, The University of Texas at Austin.

1931 M. S. Roberts Farm, Henderson County, Texas, October 8 to October 11 1931. MS on file, Texas Archeological Research Laboratory, The University of Texas at Austin.

1931 Excavation of a Burial Site on J. E. Galt Farm, Franklin County, Texas. MS on file, Texas Archeological Research Laboratory, The University of Texas at Austin. 
1931 Excavation of a Burial Site, P. S. Cash Farm, Camp County, Texas. MS on file, Texas Archeological Research Laboratory, The University of Texas at Austin.

1931 Excavation of a Burial Site, W. O. Reed Farm, in Upshur County, Texas. MS on file, Texas Archeological Research Laboratory, The University of Texas at Austin.

1931 Notes on Field Work, J. M. Riley Farm, Upshur County, Texas. MS on file, Texas Archeological Research Laboratory, The University of Texas at Austin.

1931 Notes on Field Work, H. R. Taylor Farm, Harrison County, Texas. MS on file, Texas Archeological Research Laboratory, The University of Texas at Austin.

1932 Notes on Work Done, Cherokee County, Texas, R. F. Wallace Farm, June 9, 1932 to June 11, 1932. MS on file, Texas Archeological Research Laboratory, The University of Texas at Austin.

1932 Notes on Work Done, Marion County, Texas, Hancock Farm, June 12, 1932 to June 15, 1932. MS on file, Texas Archeological Research Laboratory, The University of Texas at Austin.

1932 Exploration of a Burial Site on E. H. Moores Plantation in Bowie County, Texas. MS on file, Texas Archeological Research Laboratory, The University of Texas at Austin.

1932 Exploration of a Cemetery on Paul Mitchell Farm in Bowie County, Texas. MS on file, Texas Archeological Research Laboratory, The University of Texas at Austin.

1933 John Bragg Farm located in north edge of Village of Cuney, 300 Yards South of Highway No. 40 and 1/2 Mile East of Neches River, Cherokee County, Texas. Excavated September 1, 1933 to September 4, 1933. MS on file, Texas Archeological Research Laboratory, The University of Texas at Austin.

1933 J. M. Snow Farm, 4 Miles N.W. of Reese, Cherokee County, Texas, Excavated September 4 to September 9, 1933. MS on file, Texas Archeological Research Laboratory, The University of Texas at Austin.

1933 Some Pipes of East Texas. Bulletin of the Texas Archeological and Paleontological Society 5:69-86. 
1934 Types of East Texas Pottery. Bulletin of the Texas Archeological and Paleontological Society 6:38-57.

1934 Trenching of an Earth Mound, L. A. Hale Farm, Titus County, Texas. MS on file, Texas Archeological Research Laboratory, The University of Texas at Austin.

1934 Excavation of a Burial Site, P. G. Hightower Farm, on Cypress Creek, Franklin County, Texas. MS on file, Texas Archeological Research Laboratory, The University of Texas at Austin.

1934 Testing of a Reported Burial Site, S. P. Brown Farm, Franklin County, Texas. MS on file, Texas Archeological Research Laboratory, The University of Texas at Austin.

1934 Excavation of a Burial Site, Miss Mattie Gandy Farm, Franklin County, Texas. MS on file, Texas Archeological Research Laboratory, The University of Texas at Austin.

1935 Ornaments of East Texas Indians. Bulletin of the Texas Archeological and Paleontological Society 7:11-28.

1936 A Perpetual Fire Site. Bulletin of the Texas Archeological and Paleontological Society 8:134-174.

1938 Fire in East Texas Burial Sites. Bulletin of the Texas Archeological and Paleontological Society 10:77-113.

1938 The Fall Creek Sites. Publications No. 3802. The University of Texas at Austin.

1940 Tubular Pipes and Other Tubes in Texas. Bulletin of the Texas Archeological and Paleontological Society 12:99-157.

1940 Hatchel Site and Paul Mitchell Cemetery. Texas Archaeological News, An Occasional Report issued by The Council of Texas Archaeologists 2:1821.

1941 Pendants and Their Uses. Bulletin of the Texas Archeological and Paleontological Society 13:9-45.

1941 A Burial Site in Lamar County, Texas, Showing Possible Middle Mississippi Valley and Plains Influences. Southeastern Archaeological Conference Newsletter 2(4):7-9. 
2003 Hatchel Site and Paul Mitchell Cemetery. Caddoan Archeology Journal 13 (No. 2):25-27.

2004 Excavations of an Earthen Mound, Bowie County, Texas. Caddoan Archeology Journal 13 (Nos. 3/4):57-64.

Jackson, A. T., M. S. Goldstein, and A. D. Krieger

2000 The 1931 Excavations at the Sanders Site, Lamar County, Texas: Notes on the Fieldwork, Human Osteology, and Ceramics. Archival Series 2. Texas Archeological Research Laboratory, The University of Texas at Austin.

Jackson, D. and M. B. Cliff

2013 Intensive Archaeological Survey for the North East Regional Mobility Authority Proposed Loop 571 Extension between U.S. Highway 79 and U.S. Highway 259, Henderson, Rusk County, Texas. Document No. 120059. Atkins, Austin.

Jackson, D., L. W. Ellis, C. Wallace, K. Canavan, H. Rush, and M. B. Cliff 2011 Preliminary Report/Management Summary: National Register Eligibility Testing at Sites 41SM416, 41SM417, 41SM429, 41SM430, and 41SM431. Toll Segment 3B, Smith County, Texas: CSJ 3487-01-006. Atkins, Austin.

Jackson, H. E. and L. Heartfield

1979 Cultural Resource Assessment of the Oxbow Prospect, Northwestern Louisiana, Red River, DeSoto, and Natchitoches Parishes, Louisiana. Heartfield, Price, and Greene, Inc., Monroe.

Jackson, H. E.

2005 "Darkening the Skies in Their Flight": A Zooarchaeological Accounting of Passenger Pigeons in the Prehistoric Southeast. In Engaged Archaeology: Research Essays on North American Archaeology, Ethnobotany, and Museology, edited by M. Hegmon and B. S. Eiselt, pp. 174-199. Anthropological Papers No. 94. Museum of Anthropology, University of Michigan, Ann Arbor.

Jackson, H. E. and S. L. Scott

1995 The Faunal Record of the Southeastern Elite: The Implications of Economy, Social Relations, and Ideology. Southeastern Archaeology 14(2):103-119.

Jackson, H. E., S. L. Scott, and F. F. Schambach

2012 At the House of the Priest: Faunal Remains from the Crenshaw Site (3MI6), Southwest Arkansas. In The Archaeology of the Caddo, edited by 
T. K. Perttula and C. P. Walker, pp. 47-85. University of Nebraska Press, Lincoln.

Jackson, J. M.

1982 A Cultural Resource Survey in Martin Lake Area D: Intensive Survey I, Rusk County, Texas. Research Report No. 85. Texas Archeological Survey, The University of Texas at Austin.

Jackson, M. K., T. Middlebrook, G. Avery, H. Shafer, and B. Meissner 2012 Trade and Cultural Interaction along El Camino Real de los Tejas During the Spanish Colonial and Republic Periods in Nacogdoches County, Texas. 2 Vols. Nine Flags Museum, Nacogdoches.

Jarvis, R. W.

1972 The Folly Site, 41RK26. Texas Department of Highways, Austin.

Jeane, D. R.

1977 Blackwater Site 16WE34, Webster Parish. Louisiana Archaeological Society Newsletter 4(3):16-17.

Jelks, E. B.

1954 Appraisal of the Archeological Resources of Millwood Reservoir, Little River, Arkansas. U.S. Department of the Interior, Washington, D.C.

1961 Relationships Between the Caddoan Area and Texas. Bulletin of the Texas Archeological Society 31:65-73.

1961 Excavations at Texarkana Reservoir, Sulphur River, Texas. River Basin Survey Papers No. 21. Bureau of American Ethnology, Smithsonian Institution, Washington, D.C.

1965 The Archeology of McGee Bend Reservoir, Texas. Ph.D. dissertation, Department of Anthropology, The University of Texas at Austin.

1996 Gilbert Site. In The New Handbook of Texas, Vol. 3, edited by R. Tyler, p. 158. Texas State Historical Association, Austin.

2002 The Caddo. Journal of Northeast Texas Archaeology 16:1-28.

2006 Reminiscences of Archaeology in Texas: 1947-1968. Plains Anthropologist 51(200):597-614.

2014 Archaeological Salvage at Texas Reservoir Construction Projects: 19451969. In Dam Projects and the Growth of American Archaeology: The River Basin Surveys and the Interagency Archeological Salvage Program, 
edited by K. M. Banks and J. Czaplicki, pp. 85-94. Left Coast Press, Inc., Walnut Creek.

2014 Prologue. Bulletin of the Texas Archeological Society 85:1-3.

2017 The Archaeology of Sam Rayburn Reservoir. CRHR Research Reports, Vol. 3. Center for Regional Heritage Research, Stephen F. Austin State University, Nacogdoches.

Jelks, E. B. (editor)

1967 The Gilbert Site: A Norteno Focus Site in Northeast Texas. Bulletin of the Texas Archeological Society 37:1-248.

Jelks, E. B. and C. D. Tunnell

1959 The Harroun Site, A Fulton Aspect Component of the Caddoan Area, Upshur County, Texas. Archaeology Series No. 2. Department of Anthropology, The University of Texas at Austin.

Jenkins, R. E.

2003 A Cultural Resources Survey of AHTD Job No. 040353 Highway 272 to Highway 71 Resurface and Shoulders, Polk County. AHTD Job No. 040353. Arkansas Highway and Transportation Department, Environmental Division, Little Rock.

Jensen, H. E.

1968 Coral Snake Mound (X16SA48). Bulletin of the Texas Archeological Society 39:9-44.

1968 Archaeological Investigations in the Toledo Bend Reservoir: 1966-1967. Archaeology Salvage Project, Southern Methodist University, Dallas.

Jeter, M. D.

2002 From Prehistory through Protohistory to Ethnohistory near the Northern Lower Mississippi Valley. In The Transformation of the Southeastern Indians, 1540-1760, edited by E. Ethridge and C. Hudson, pp. 177-223. University Press of Mississippi, Jackson.

2007 The Outer Limits of Plaquemine Culture: A View from Northerly Borderlands. In Plaquemine Archaeology, edited by M. A. Rees and P. C. Livingood, pp. 161-195. University of Alabama Press, Tuscaloosa.

2012 Ripe for Colonial Exploitation: Ancient Traditions of Violence and Enmity as Preludes to the Indian Slave Trade. In Native American Adoption, Captivity, and Slavery in Changing Contexts, edited by M. Carocci and S. Pratt, pp. 23-46. Palgrave MacMillan, New York. 
2012 ARF Grant Funds Date on Taylor Mound 3 Corncobs. Field Notes (Newsletter of the Arkansas Archeological Society) 369:3-5.

Jeter, M. D. (editor)

1990 Edward Palmer's Arkansaw Mounds. University of Arkansas Press, Fayetteville. New paperback edition published in 2009 by University of Alabama Press, Tuscaloosa.

Jeter, M. D. and A. M. Early

1999 Prehistory of the Saline River Drainage Basin, Central to Southeast Arkansas. In Arkansas Archaeology: Essays in Honor of Dan and Phyllis Morse, edited by R. C. Mainfort, Jr., and M. D. Jeter, pp. 31-63. University of Arkansas Press, Fayetteville.

Jeter, M. D. and J. J. Mintz

1990 National Register of Historic Places Eligibility Testing at the Fish Lake Site (3HE287) on the Red River, Hempstead County, Arkansas. Project Report No. 694. Arkansas Archeological Survey, Fayetteville.

Jeter, M. D., J. C. Rose, I. Williams, Jr., and A. M. Harmon

1989 Archeology and Bioarcheology of the Lower Mississippi Valley and TransMississippi South in Arkansas and Louisiana. Research Series No. 37. Arkansas Archeological Survey, Fayetteville.

Johanson, E. N.

2011 Predictive Modeling in Western Louisiana: Prehistoric and Historic Settlement in the Kisatchie national Forest. Master's thesis, Department of Anthropology, University of Tennessee, Knoxville.

Johnson, C. G. and D. T. Hughes

1992 Archaeological Test Excavations at Bat Cave, Dl-4, Delaware County, Oklahoma. Anthropology Research Laboratory Department of Anthropology, Wichita State University, Wichita.

Johnson, L., Jr.

1961 An Archeological Survey of Blackburn Crossing Reservoir on the Upper Neches River. Bulletin of the Texas Archeological Society 31:213-238.

1962 The Yarbrough and Miller Sites of Northeastern Texas, with a Preliminary Definition of the LaHarpe Aspect. Bulletin of the Texas Archeological Society 32:141-284.

1992 Stealing Secrets from Dead Potters: A Plea for Painstaking Ceramic Sleuthing. APR News \& Views 4(1):16-19. Department of Archeological Planning \& Review, Texas Historical Commission, Austin. 
1996 Fred Yarbrough Site. In The New Handbook of Texas, Vol. 2, edited by R. Tyler, p. 1164. Texas State Historical Association, Austin.

Johnson, L., Jr. and E. B. Jelks

1958 The Tawakoni-Yscani Village, 1760: A Study in Site Identification. Texas Journal of Science 10(4):405-422.

Jones, $\mathrm{A}$.

1883 Mounds and Other Remains in Independence County, Arkansas. Annual Report of the Board of Regents of the Smithsonian Institution, pp. 541542. Smithsonian Institution, Washington, D.C.

Jones, A. and L. E. Sanders

1978 The Spiro Mounds Archeological Park and Interpretive Center. Oklahoma Anthropological Society Newsletter 26(8):710.

Jones, B. C.

1957 The Grace Creek Sites, Gregg County, Texas. Bulletin of the Texas Archeological Society 28:198-231.

1968 The Kinsloe Focus: A Study of Seven Historic Caddoan Sites in Northeast Texas. Master's thesis, Department of Anthropology, University of Oklahoma, Norman.

Jones, C. C., Jr.

1873 Antiquities of the Southern Indians. D. Appleton \& Co., New York.

Jones, D. C., M. K. Shuman, and M. Wiedenfeld

1995 Cultural Resources Survey for the Proposed Expanded Right-of-Way for U.S. Highway 171 Between Zwolle and Grand Cane, Sabine and DeSoto Parishes, Louisiana.Gulf Engineers and Consultants, Inc.

Jones, E. E.

2014 Spatiotemporal Analysis of Old World Diseases in North America, A.D. 1519-1807. American Antiquity 79(3):487-506.

Jones, L. K, D. Moore, D. Brown, C. Frederick, W. P. Glander, R. Rogers, and M. Parker

1993 Cultural Resources Survey of the Proposed Monticello B-2 Surface Mine, Titus County, Texas. Document No. 880206. Espey Huston \& Associates, Inc., Austin.

Jones, R. S.

2009 Cultural Resource Inventory of 1,319 Acres at Lake B. A. Steinhagen and Lake Sam Rayburn, Angelina, Jasper, Tyler, and Nacogdoches County, Texas. Ecological Communications Corporation, Austin. 
Jones, R. S. and W. N. Trierweiler

2005 A Cultural Resource Inventory of 350 Acres at Lake Sam Rayburn, Angelina County, Texas. Ecological Communications Corporation, Austin.

2008 Cultural Resource Inventory of 166 Acres at Lake Wright Patman, Bowie County, Texas. Ecological Communications Corporation, Austin.

Jones, V. H.

1949 Maize from the Davis Site: Its Nature and Interpretation. In The George C. Davis Site, Cherokee County, Texas, by H. P. Newell and A. D. Krieger, pp. 241-249. Memoirs No. 5. Society for American Archaeology, Menasha, Wisconsin.

Joseph, J. W., L. E. Raymer, G. X. Guan, M. B. Reed, C. Hanson, and T. M. Hamby

1997 Archeological Survey of 8380 Acres in the Choctaw, Kiamichi, Mena, Oden, Poteau, and Tiak Districts in the West Zone of the Ouachita National Forest, Scott, Polk, Yell, and Montgomery Counties, Arkansas, and Le Flore and McCurtain Counties, Oklahoma. Technical Report 217. New South Associates, Stone Mountain.

Judjahn, S. K.

1999 Land Use in the Late Prehistoric Post Oak Savannah of Texas. Master's thesis, Department of Anthropology, Texas A\&M University, College Station.

Jurney, D. H.

1981 The Source and Distribution of Specialized Stone Tools in the Ozarks. Midcontinental Journal of Archaeology 6(1):17-32.

1994 The original distribution of Bois d'arc, Part I. Caddoan Archeology Newsletter 5(2):6-13.

2000 Passport in Time Archaeological Investigations at the Hargrove Lake Site (41HO150), Houston County, Texas. U.S. Forest Service, Lufkin.

2003 Barnes Environmental Analysis. Forest Service Project 02-10-04-03. Ozark-St. Francis National Forests, Russellville.

2003 Brock Timber and Wildlife Project. Forest Service Project 03-10-06-03. Ozark-St. Francis National Forests, Russellville.

2003 Sie Hollow Environmental Analysis. Forest Service Project 02-10-04-04. Ozark-St. Francis National Forests, Russellville. 
2013 Anthropology of Fire in the Ozark Highland Region. In Proceedings of the $4^{\text {th }}$ Fire in Eastern Oak Forests Conference, pp. 12-33. GTR-NRS-P-102.

2014 Passenger Pigeon Remains from Saltpetre Cave (3NW29), Newton County, Arkansas. Field Notes (Newsletter of the Arkansas Archeological Society) 379:8-13.

Jurney, D. H. (editor)

1992 Archeological Survey, Historic Site Evaluations, and Excavations at the Jewett Mine, Leon and Freestone Counties, Texas: 1989 Field Season. Archaeology Research Program, Institute for the Study of Earth and Man, Southern Methodist University, Dallas.

Jurney, D. H. and V. Bergstrom

2001 Silica Froth: An Indicator of Thatch Architecture. Journal of Northeast Texas Archaeology 15:1-7.

Jurney, D. H. and J. Bohlin

1993 Archaeological Survey of Cooper Lake, Delivery Order Number G 1989. Cultural Resources Studies for Cooper Lake, Hopkins and Delta Counties, Texas. Archaeology Research Program, Southern Methodist University, Dallas.

Jurney, D. H. and W. Young

1995 Southwestern Pottery and Turquoise in Northeastern Texas. Caddoan Archeology Newsletter 6(2):15-28.

Jurney, D. H., J. Bohlin, S. E. Linder Linsley, S. C. Caran, and D. R. Pedler 1993 Archaeological Survey of Cooper Lake, Delivery Order Number 7, 1989. Cultural Resources Studies for Cooper Lake, Hopkins and Delta Counties, Texas. Archaeology Research Program, Southern Methodist University, Dallas.

Jurney, D. H., R. Evans, J. Ippolito, and V. Bergstrom

2004 The role of wildland fire in portions of southeastern North America. In Proceedings $22^{\text {nd }}$ Tall Timbers fire ecology conference: fire in temperate, boreal, and montane ecosystems, edited by K. E. M. Galley and W. J. de Groot, pp. 95-116. Tall Timbers Research Station, Tallahassee.

Kahl, K., D. C. McKay, and R. Procter

1999 Results of Cultural Resources Inventory Within 836 Acres Along the Red River, Choctaw County, Oklahoma and Lamar County, Texas. Report of Investigations Number 2. Wendy Lopez \& Associates, Dallas.

Kassabaurn, M. C., D. J. Cranford, and E. S. Nelson 
2011 Multiple Modes of Monumentality: Case Studies from the American South. The SAA Archaeological Record 11(4):33-37.

Kay, M.

1984 Late Caddo Subtractive Technology in the Red River Basin. In Cedar Grove: An Interdisciplinary Investigation of a Late Caddo Farmstead in the Red River Valley, edited by N. L. Trubowitz, pp. 174-206. Research Series No. 23. Arkansas Archeological Survey, Fayetteville.

1986 Caddoan Mound Construction Chronologies of the Western Ozark Highland, Arkansas. In Contributions to Ozark Prehistory, edited by G. Sabo, III, pp. 77-79. Research Series No. 27. Arkansas Archeological Survey, Fayetteville.

Kay, M. and G. Sabo III 2006 Mortuary Ritual and Winter Solstice Imagery of the Harlan-Style Charnel House. Southeastern Archaeology 25(1):29-47.

Kay, M., G. Sabo III, and R. J. Merletti

1989 Late Prehistoric Settlement Patterning: A View from Three Caddoan CivicCeremonial Centers in Northwest Arkansas. In Contributions to Spiro Archaeology: Mound Excavations and Regional Perspectives, edited by J. D. Rogers, D. G. Wyckoff, and D. A. Peterson, pp. 129-157. Studies in Oklahoma's Past No. 16. Oklahoma Archeological Survey, Norman.

Keith, K. D.

1973 Paleostomatology at the Moore Site (Lf-31), LeFlore County, Oklahoma. Bulletin of the Oklahoma Anthropological Society 22:148-158.

Keith, K. D. and D. R. Lopez (editors)

1978 The Cotton Site: Test Excavations and Findings at Lf207, LeFlore County, Oklahoma: State Highway Project US 59 (F225). Papers in Highway Archaeology No. 4. Oklahoma Department of Transportation, Planning Division, Oklahoma City.

Keller, J. E.

1974 The Subsistence Paleoecology of the Middle Neches Region of Eastern Texas. Ph.D. dissertation, Department of Anthropology, The University of Texas at Austin.

1975 Paleoecological Considerations and East Texas Archeology. Bulletin of the Texas Archeological Society 46:243-248.

1977 Subsistence Paleoecology of the George C. Davis Site: Strategies and Consequences. Western Canadian Journal of Anthropology 7:100-128. 
1990 A Cultural Resources Survey of Certain Portions of the South Hallsville Project for the Sabine Mining Company, Hallsville, Texas. Southern Archaeological Consultants, Inc., Harlingen.

1992 Archaeological Survey and Testing at the South Hallsville No. 1 Mine, Harrison County, Texas. Report of Investigations 3-93. Southern Archaeological Consultants, Inc., Harlingen, Texas.

1993 Excavations at the Gray's Pasture Site (41HS524). Caddoan Archeology Newsletter 3(4):26-28.

2000 An Archaeological Survey of Portions of the South Marshall Permit Area, Harrison County, Texas. Report of Investigations No. 7-2000. Southern Archaeological Consultants, Los Fresnos, Texas.

Kelley, D. B.

1986 A Research Design for Archaeological Survey and Testing Within Bayou Bodcau Reservoir, Bossier and Webster Parishes, Louisiana and Lafayette County, Arkansas. Coastal Environments, Inc., Baton Rouge.

1991 Archaeological Survey of the Bear Realignment Area, Miller County, Arkansas. Coastal Environments, Inc., Baton Rouge.

1998 Protohistoric and Historic Caddoan Occupation of the Red River Valley in Northwest Louisiana. In The Native History of the Caddo: Their Place in Southeastern Archeology and Ethnohistory, edited by T. K. Perttula and J. E. Bruseth, pp. 91-111. Studies in Archeology 30. Texas Archeological Research Laboratory, The University of Texas at Austin.

2006 The Burnitt Site: A Late Caddoan Occupation in the Uplands of the Sabine River Basin of Louisiana. Coastal Environments, Inc., Baton Rouge.

2010 Ceramics from Caddo Mounds State Park (41CE19) Monitoring Project. In Archaeological Monitoring Investigations at Site 41CE19, The Caddo Mounds State Historic Site, Cherokee County, Texas, by A. Peyton and J. D. Lowe, pp. A-1 to A-10. Cultural Resource Report No. 10-311. SWCA Environmental Consultants, Austin.

2012 The Belcher Phase: Sixteenth- and Seventeenth-Century Caddo Occupation of the Red River Valley in Northwest Louisiana and Southwest Arkansas. In The Archaeology of the Caddo, edited by T. K. Perttula and C. P. Walker, pp. 411-430. University of Nebraska Press, Lincoln.

Kelley, D. B. (editor) 
1994 The McClelland and Joe Clark Sites: Protohistoric-Historic Caddoan Farmsteads in Southern Bossier Parish, Louisiana. Coastal Environments, Inc., Baton Rouge.

1997 Two Caddoan Farmsteads in the Red River Valley. Research Series No. 51. Arkansas Archeological Survey, Fayetteville.

Kelley, D. B. and C. L. Coxe

1996 Cultural Resources Survey of Levee Rehabilitation/Restoration Areas Along the Red River Between Fulton, Arkansas and the Louisiana State Line, Items 4, 5 and 9. Coastal Environments, Inc., Baton Rouge.

Kelley, D. B. and B. Gregory

2014 Phase II Archaeological Test Excavations at Site 16CD294, Route I-49, Caddo Parish, Louisiana. Coastal Environments, Inc., Baton Rouge.

Kelley, D. B. and M. J. Guccione

1997 Cultural Resources Survey and Evaluation of Portions of the Moore/Higginbotham Site (3MI3/30), Within Item 2 of the Red River Below Denison Dam Levee Rehabilitation/Restoration Project, Miller County, Arkansas. Coastal Environments, Inc., Baton Rouge.

Kelley, D. B. and S. S. Victor

1989 Archaeological and Historical Investigations of the Candler Lake, Fulton, and Temple Revetment Areas, Red River, Arkansas. Coastal Environments, Inc., Baton Rouge.

Kelley, D. B. and T. Wells

1995 Archaeological Survey and Testing within the Grand Bayou Reservoir Area, Red River Parish, Louisiana. Coastal Environments, Inc., Baton Rouge.

Kelley, D. B., D. G. Hunter, E. S. Gardner, D. C. Weinand, A. Tine, and L. L. Tieszen

1996 The McLelland and Joe Clark Sites: Protohistoric-Historic Caddo Farmsteads in the Red River Valley of Northwest Louisiana. Southeastern Archaeology 15(1):81-102.

Kelley, D. B., D. G. Hunter, K. M. Roberts, S. L. Scott, and B. S. Haley 2010 The Burnitt Site (16SA204): A Late Caddoan Occupation in the Uplands of the Sabine River Basin. Louisiana Archaeology 31:4-33.

Kelley, D. B., S. S. Victor, and M. D. Freeman

1987 Archaeology in the Flat Woods. An Intensive Survey of the Louisiana Army Ammunition Plant, Bossier and Webster Parishes, Louisiana. Coastal Environments, Inc., Baton Rouge. 
Kelley, J. C.

1996 Loma Alta Site. In The New Handbook of Texas, Vol. 4, edited by R. Tyler, p. 265. Texas State Historical Association, Austin.

Kelly, M. W.

1995 Phase II Testing of Five Archeological Sites - 34CH258, 34CH260, 34CH266, and 34CH267 - Located in the Proposed WFEC Railroad Company Hugo Station Railroad Project Right-of-Way Choctaw County, Oklahoma. George Butler Associates, Inc., Lenexa, Kansas.

Kenmotsu, N. A

1992 The Mayhew Site: A Possible Hasinai Farmstead, Nacogdoches County, Texas. Bulletin of the Texas Archeological Society 63:135-174.

2001 Salt Well Slough (41RR204). Bulletin of the Texas Archeological Society 72:213-222.

2005 Investigations at the Salt Well Slough Site (41RR204), a Salt Making Site in Red River County, Texas. Archeological Reports Series, No. 4. Texas Historical Commission, Austin.

Kenmotsu, N.A. and T. K. Perttula

2014 Critical Thinking in Archeology: Papers in Memory of Dee Ann Story. Bulletin of the Texas Archeological Society 85:5-7.

Kenmotsu, N. A. and T. K. Perttula (editors)

1993 Archeology in the Eastern Planning Region, Texas: A Planning Document. Cultural Resource Management Report 3. Department of Antiquities Protection, Texas Historical Commission, Austin.

Kerr, $\mathrm{H}$.

1964 Neosho Focus Knives. Oklahoma Anthropological Society Newsletter 12(2):4-5.

Kibler, K. W.

2012 The Role of Exotic Materials in Toyah Assemblages in a Late Prehistoric Economic and Social System. In The Toyah Phase of Central Texas: Late Prehistoric Economic and Social Processes, edited by N. A. Kenmotsu and D. K. Boyd, pp. 76-89. Texas A\&M University Press, College Station.

Kidder, T. R.

1993 The Glendora Phase: Protohistoric-Early Historic Culture Dynamics on the Lower Ouachita River. In Archaeology of Eastern North America, Papers in Honor of Stephen Williams, edited by J. B. Stoltman, pp. 231-260. Mississippi Department of Archives and History, Jackson. 
1998 Rethinking Caddoan-Lower Mississippi Valley Interaction. In The Native History of the Caddo: Their Place in Southeastern Archeology and Ethnohistory, edited by T. K. Perttula and J. E. Bruseth, pp. 129-143. Studies in Archeology 30. Texas Archeological Research Laboratory, The University of Texas at Austin.

King, F. B.

1984 Plant Remains from the Cedar Grove (3LA97) and Sentell (3LA128) Sites. In Cedar Grove: An Interdisciplinary Investigation of a Late Caddo Farmstead in the Red River Valley, edited by N. L. Trubowitz, pp. 207210. Research Series No. 23. Arkansas Archeological Survey, Fayetteville.

King, H. E.

1972 Discoveries in Le Flore County. Oklahoma Anthropological Society Newsletter 20(6):2-4.

1975 Recent Finds in Northeastern Oklahoma. Oklahoma Anthropological Society Newsletter 23(7):6-7.

King, H. R.

1981 A Brief History of the Spiro Mound Complex. Bulletin of the Oklahoma Anthropological Society 30:27-32.

King, H. R. and R. King

1985 Discoidals or Chungke Stones. Oklahoma Anthropological Society Newsletter 33(4):8-10.

King, K. and M. Turner

1993 The West Island Site (41 MX65). Notes on Northeast Texas Archaeology 1:25-33.

King, M. E. and J. S. Gardner

1981 The Analysis of Textiles from Spiro Mound, Oklahoma. In "The Research Potential of Anthropological Museum Collections," edited by A.-M. E. Cantwell, J. B. Griffin, and N. A. Rothschild. Annals of the New York Academy of Science 376:123-139.

Kizzia, G. L.

1968 Burial Customs of the Caddo. Central States Archaeological Journal 15(2):58-63.

Kleinschmidt, U. K. W. 
1982 Review and Analysis of the A. C. Saunders Site, 41AN19, Anderson County, Texas. Master's thesis, Department of Anthropology, The University of Texas at Austin.

Klinger, T. C.

1986 Cultural Resources Evaluation at Tenkiller Ferry Lake, Cherokee and Sequoyah Counties, Oklahoma. Report 86-9. Historic Preservation Associates, Fayetteville.

2004 Bentonville Water System Improvements, Osage Creek Crossing. Report 04-01. Historic Preservation Associates, Fayetteville.

2004 Community Corrections Technical Violations Center; ADC Malvern Unit Development Monitoring. Report 04-14. Historic Preservation Associates, Fayetteville.

2004 Nashville Rural Water Association: Additions to the Phase III \& IV Systems; Historic Properties Review of Proposed Water System Improvements. Report 04-15. Historic Preservation Associates, Fayetteville.

2004 Seven Hills Transitional Housing. Report 04-16. Historic Preservation Associates, Fayetteville.

Klinger, T. C. and R. C. Cande

1987 Broken Bow Lake: Cultural Resources Survey at Broken Bow Lake, McCurtain County, Oklahoma. Reports 87-7. Historic Preservation Associates, Fayetteville.

1987 Cultural Resources Survey at Hugo Lake, Choctaw and Pushmataha Counties, Oklahoma. Reports 87-12. Historic Preservation Associates, Fayetteville.

Klinger, T. C. and J. L. Gray, IV

1999 CMN Business Park II: Phases I, II, and III. Report 99-15. Historic Preservation Associates, Fayetteville.

1999 Stephens Production Fort Chaffee, Fort 1-19 Well. Report 99-19. Historic Preservation Associates, Fayetteville.

1999 Stephens Production Fort Chaffee Fort \#1-16 Well. Report 99-11. Historic Preservation Associates, Fayetteville.

1999 Stephens Production Fort Chaffee Reserve \#2-36 Well. Report 99-12. Historic Preservation Associates, Fayetteville. 
2000 Fort Chaffee Fort \#1-34. Report 00-03. Historic Preservation Associates, Fayetteville.

2003 James Kimzey Regional Water District, Lonsdale Road Service Area. Report 03-12. Historic Preservation Associates, Fayetteville.

2004 Wal-Mart Supercenter 0388-01; Phase II Assessment in Connection with a Proposed Wal-Mart Store in Fort Smith. Report 04-12. Historic Preservation Associates, Fayetteville.

Klinger, T. C. and K. A. Hinkle

1987 Applegate Cove Burial: Burial Excavation at 34SQ290, Robert S. Kerr Lock and Dam, Sequoyah County, Oklahoma. Reports 87-5. Historic Preservation Associates, Fayetteville.

Klinger, T. C. and S. M. Imhoff

1986 Lee Creek: Evaluation of Selected Archeological Resources in the Lower Lee Creek Valley, Crawford County, Arkansas and Sequoyah County, Oklahoma. Reports 86-11. Historic Preservation Associates, Fayetteville.

Klinger, T. C. and J. A. Ross

1999 Paron Water System Improvements. Report 99-13. Historic Preservation Associates, Fayetteville.

Klinger, T. C. and J. W. Smith

1992 Phase II Assessment of 3HE310, Ozan Creek Watershed Structure 14, Hempstead County, Arkansas. Report 92-26. Historic Preservation Associates, Fayetteville.

Klinger, T. C., L. L. Ayres, D. R. Dickson, M. J. Guccione, S. M. Imhoff, and J. W. Smith

1993 Graham Farm (3WA753) and Winn Creek (3WA767): Data Recovery at Two Prehistoric Sites along the Relocation Route of U.S. Highway 71 within the Ozark-Arkansas-Ouachita Region, Washington County, Arkansas. Reports 93-3. Historic Preservation Associates, Fayetteville.

Klinger, T. C., D. R. Dickson, and J. L. Gray IV

1999 U. S. 71 Corridor Study, 3BE634 Phase II Assessment. Report 99-17. Historic Preservation Associates, Fayetteville.

1999 South Mountain Water Association System Improvements. Report 99-06. Historic Preservation Associates, Fayetteville.

2003 Magnet-Butterfield Water Association Gourd Neck-Bettis Road Additions. Report 03-06. Historic Preservation Associates, Fayetteville. 
Klinger, T. C., D. R. Dickson, and J. W. Smith

1992 Reynolds Metals Company Outfall Ditch. Report 92-35. Historic Preservation Associates, Fayetteville.

Klinger, T. C., D. Dickson, J. A. Ross, J. L. Gray IV, 2000 Pike County Murfreesboro, South Pike County Water System Improvements. Report 00-08. Historic Preservation Associates, Fayetteville.

Klinger, T. C., D. R. Dickson, K. L. Hoffman, and J. Gates 1996 34PS41-Phase III Data Recovery: Phase III Data Recovery Efforts at 34PS41, a Prehistoric Site Located in Structure 26 of the BrushyPeaceable Watershed Study Region 6, Ouachita Mountains Southeastern Region, Pittsburg County, Oklahoma. Historic Preservation Associates, Fayetteville.

Klinger, T. C., J. A. Ross, D. R. Dickson, J. L. Gray IV, and G. G. Dunn 2001 Malvern Unit, Arkansas Department of Corrections Facility. Report 01-27. Historic Preservation Associates, Fayetteville.

Klinger, T. C., J. W. Smith, and M. D. Bittinger

1994 Historic Properties Survey of 433 Acres in the vicinity of DeGray Lake within the Ozark-Arkansas-Ouachita Region, Clark and Hot Springs counties, Arkansas. Report 94-08. Historic Preservation Associates, Fayetteville.

Klinger, T., J. W. Smith, D. R. Dickson, and A. J. Hawkins

1997 Bayou Bodcau Dam and Reservoir 1997. Report 97-13. Historic Preservation Associates, Fayetteville.

Kotter, S., R. Rogers, and K. Yancy

1992 Cultural Resources Survey of the Proposed Martin Lake B West Study Area, Panola County, Texas. Document No. 9003008. Espey, Huston \& Associates, Inc., Austin.

Kotter, S., M., L. Jones, C. Frederick, and W. Glander

1991 An Archaeological Investigation of 41TT182 in the Monticello-Winfield South Surface Mine, Titus County, Texas. Document No. 910264. Espey, Huston \& Associates, Inc., Austin.

Kotter, S. M., R. Rogers, R. Taylor, K. Reese-Taylor, and W. E. Glander 1993 Archaeological Investigations within the Monticello B-2 First Five Year Disturbance Area, Titus County, Texas. Document No. 920013. Espey, Huston \& Associates, Inc., Austin.

Kozuck, L. 
2002 Olivella Beads from Spiro and the Plains. American Antiquity 67(4):697709.

Kraft, K. C.

1997 The Harkey Mound Site: Analysis of the 1975 Test Excavations at Harkey \#3 (34Mc-206). Archaeological Research Report No. 16. Oklahoma Conservation Commission, Oklahoma City.

1998 An Examination of Materials from Minimal Testing at Harkey \#3 (Harkey Mound), McCurtain County, Oklahoma. Bulletin of the Oklahoma Anthropological Society 46:41-106.

Krieger, A.

1941 An Analytical System for East Texas Pottery. Southeastern Archaeological Conference Newsletter 2(4):7-9.

1944 Archeological Horizons in the Caddoan Area. Revista Mexicana de Estudios Historicos 7:154-156.

1945 An Inquiry into Supposed Mexican Influence on a Prehistoric Cult in the Southern United States. American Anthropologist 47:483-515.

1946 Culture Complexes and Chronology in Northern Texas, with Extensions of Puebloan Datings to the Mississippi Valley. Publication No. 4640. The University of Texas, Austin.

1947 The Eastward Extension of Puebloan Datings Toward Cultures of the Mississippi Valley. American Antiquity 12(3):141-148.

1947 The First Conference on the Caddoan Archaeological Area. American Antiquity 12:198-207.

1948 Importance of the "Gilmore Corridor" in Culture Contacts between Middle America and the Eastern United States. Bulletin of the Texas Archeological and Paleontological Society 19:155-178.

1949 The Archeological Background of the Caddo. Plains Anthropologist Newsletter 3(1):2.

1951 A Radiocarbon Date on the Davis Site in East Texas. American Antiquity 17(2):144-145.

1953 Recent Developments in the Problem of Relationships Between the Mexican Gulf Coast and Eastern United States. Revista Mexicana de Estudios Anthropologicos 2-3:497-518. 
1953 Review of "Survey of Caddoan Area Archaeology" by K. G. Orr. American Antiquity 19(2):184-187.

1961 Discussion of James B. Griffin, Relationships Between the Caddoan Area and the Mississippi Valley. Bulletin of the Texas Archaeological Society 31:43-51.

2000 The Pottery of the Sanders Farm. In The 1931 Excavations at the Sanders Site, Lamar County, Texas: Notes on the Fieldwork, Human Osteology, and Ceramics, by A. T. Jackson, M. S. Goldstein, and A. D. Krieger, pp. 131-144. Archival Series 2. Texas Archeological Research Laboratory, The University of Texas at Austin.

2009 Archaeological Horizons in the So-Called Caddo Area. Archival Series 3. Texas Archeological Research Laboratory, The University of Texas at Austin.

Kusnierz, N. E.

2016 Leadership and Social Dynamics at Brackett (34CK43): An Archaeological Study of a Mississippian Period Mound Site in Eastern Oklahoma.

Master's thesis, Department of Anthropology, University of Oklahoma, Norman.

Kuttruff, C., S. Moore, and E. Peacock

1996 Cultural Resources Inventory of Twelve Timber Thinning Areas, Bayou Bodcau Reservoir, Bossier and Webster Parishes, Louisiana, Fiscal Year 1995. Panamerican Consultants, Inc., Tuscaloosa.

Kuttruff, J. T.

1988 Textile Attributes and Production Complexity as Indicators of Caddoan Status Differentiation in the Arkansas Valley and Southern Ozark Regions. Ph.D. dissertation, Department of Anthropology, Ohio State University, Columbus.

1993 Mississippian Status Differentiation through Textile Analysis: A Caddoan Example. American Antiquity 58:125-145.

Kvamme, K. L.

2000 Geophysical Investigations at the Kaufman-Roitsch Site (41RR16), Texas. http://cast.uark.edu/nadag/, accessed October 3, 2010.

Lackowicz, R., A. A. Krishnan, and W. Athens

2009 Results of Additional Phase I Cultural Resources Investigations of the Proposed Gulf Crossing Project in Grayson, Fannin, Lamar, Franklin, Titus, Morris, and Cass Counties, Texas. R. Christopher Goodwin and Associates, Inc., New Orleans. 
Lackowicz, R., H. Raab, S. B. Smith, W. Hellet, M. Handly, J. Eberwine, and A. Brown

2009 Results of a Phase I Cultural Resources Survey and Archeological Inventory of the Proposed Gulf Crossing Project in Grayson, Fannin, Lamar, Delta, Hopkins, Franklin, Titus, Morris, and Cass Counties, Texas. R. Christopher Goodwin \& Associates, Inc., New Orleans.

Ladwig, B. L.

2014 Pre-Columbian Burial Rites: Burial Practices Among Prehistoric Native Americans: Southeast Region, Volume IV. Lexington, Kentucky.

Lafferty, R. H. III

1994 Prehistoric Exchange in the Lower Mississippi Valley. In Prehistoric Exchange Systems in North America, edited by T. G. Baugh and J. E. Ericson, pp. 177-213. Plenum Press, New York.

2001 Archeological Survey of the Unsurveyed Portions of the River Mountain Pumped Storage Reservoir, Logan County, Arkansas. Mid-Continental Research Associates, Inc., Lowell, Arkansas.

2001 Cultural Resources Investigations of the AES River Mountain Pumped Storage Project, Logan County, Arkansas. Management Summary \#1. Mid-Continental Research Associates, Inc., Lowell, Arkansas.

2003 An Archeological Survey of Elkins Cellular Telephone Tower (FCC License No. 1237302), Washington County, Arkansas. MCRA Report 2003-1. Mid-Continental Research Associates, Inc., Lowell, Arkansas.

Lafferty, R. H., A. M. Early, M. C. Sierzchula, M. C. Hill, G. S. Powell, N. H. Lopinot, L. S. Cummings, S. L. Scott, S. K. Nash, and T. K. Perttula

2000 Data Recovery at the Helm Site, 3HS449, Hot Spring County, Arkansas. MCRA Report 2000-1. Mid-Continental Research Associates, Inc., Lowell, Arkansas.

Lafferty, R. H. and L. Langley-Ware

2004 Phase II Archeological Testing of Sites 3HS95 and 3HS187 for AHTD Job 060938, Ouachita River Structures and Approaches (Malvern), Hot Spring County, Arkansas. Mid-Continental Research Associates, Inc., Lowell, Arkansas.

Lafferty, R. H. and M. C. Sierzchula

2002 NRHP Testing at the Osage Springs Site and the Trout Farm II Site. MCRA Report 2002-3. Mid-Continental Research Associates, Lowell, Arkansas. 
Lafferty, R. H., M. C. Sierzchula, K. M. Hess, and K. Sturtevant

2005 Phase III Archeological Data Recovery by Controlled Surface Collection at Site 3WA1166, Blessings Golf Club, Washington County, Arkansas. MCRA Report No. 2004-7. Mid-Continental Research Associates, Lowell, Arkansas.

Lafferty, R. H., M. C. Sierzchula, and G. Powell

2001 National Register of Historic Places Testing of 3MA22 and 3MA322. MCRA Report 2001-4. Mid-Continental Research Associates, Lowell, Arkansas.

Lambert, S. P.

2017 A Stylistic and INAA Study pf Formative Caddo Fine Wares: Evidence for Centralized Production and Long-Distance Exchange between the Northern and Southern Caddo. Ph.D. dissertation, Department of Anthropology, University of Oklahoma, Norman.

Lankford, G. E.

2006 Some Southwestern Influences in the Southeastern Ceremonial Complex. The Arkansas Archeologist 45:1-25.

2007 The "Path of Souls": Some Death Imagery in the Southeastern Ceremonial Complex. In Ancient Objects and Sacred Realms: Interpretations of Mississippian Iconography, edited by F. K. Reilly III and J. F. Garber, pp. 174-212. University of Texas Press, Austin.

2010 The Swirl-Cross and the Center. In Visualizing the Sacred: Cosmic Visions, Regionalism, and the Art of the Mississippian World, edited by G. E. Lankford, F. K. Reilly III, and J. F. Garber, pp. 251-275. University of Texas Press.

2012 Weeding out the Noded. The Arkansas Archeologist 50:50-68.

2014 Following the Noded Trail. The Arkansas Archeologist 53:51-68.

Largent, F. B., Jr.

1995 Cultural Resource Investigations of Three Park Areas at Lake Eufaula, McIntosh and Pittsburg Counties, Oklahoma. Miscellaneous Reports of Investigations No. 70. Geo-Marine, Inc., Plano.

Largent, F. B. and M. B. Cliff

1998 Barksdale Air Force Base: Phase I Cultural Resources Survey of Approximately 3,505 Acres. Report of Investigations, No. 8. United State Air Force Air Combat Command Series. Geo-Marine, Inc., Plano, Texas.

Largent, F. B., Jr., D. Beene, M. B. Cliff, and S. Hunt 
1997 Cultural Resources Testing of Two Sites within the White Oak Creek Wildlife Management Area (WOCMA), Bowie and Titus Counties, Texas. White Oak Creek Wildlife Management Area Archaeological Technical Series, Report of Investigations No. 6. Geo-Marine, Inc., Plano.

Largent, F. B., S. Gaither, K. Krapf, M. B. Cliff, and W. J. Autin 1997 Barksdale Air Force Base: Phase I Cultural Resources Survey of Approximately 3,500 Acres. Report of Investigations, No. 3. United State Air Force Air Combat Command Series. Geo-Marine, Inc., Plano, Texas.

Largent, F. B., Jr., C. Lintz, M. Huhnke, S. M. Hunt, S. N. Allday, E. G. Salo, and M. M. Green

2004 Intensive Pedestrian Survey of the New Lake O' The Pines Southside Regional Water Supply System, Gregg, Harrison, Marion, and Upshur Counties, Texas. Miscellaneous Reports of Investigations No. 205. GeoMarine, Inc., Plano.

LaVardera, L. T.

1983 Archaeological Testing at 41HS254, South Hallsville Project, Harrison County, Texas. North American Consultants, Inc., Dallas.

1983 Archaeological Testing at 41HS227 and 41HS229, South Hallsville Project. North American Consultants, Inc., Dallas.

1984 Summary Report: Motor Grading of 41HS117, South Hallsville Project, Harrison County, Texas. North American Consultants, Inc., Dallas.

1985 Backhoe Trenching at 41HS282, South Hallsville Project, Harrison County, Texas. North American Consultants, Inc., Dallas.

LaVardera, L. T. and J. E. Keller

1987 Cultural Resources Investigations at the Little Cypress Reservoir. Harrison County, Texas. North American Consultants, Inc., Dallas.

Lawrence, D. M., B. M. Kemp, J. Eshleman, R. L. Jantz, M. Snow, D. George, and D. G. Smith

2010 Mitochondrial DNA of Protohistoric Remains of an Arikara Population from South Dakota: Implications for the Macro-Siouan Language Hypothesis. Human Biology 82(2):157-178.

Lawrence, $\mathrm{H}$.

1993 Cultural Resource Survey Report 08-09-08-298 for Site Preparation in Compartment 1023, Oden Ranger District, Ouachita National Forest. Ouachita National Forest, Hot Springs.

Lawrence, K., S. Carpenter, K. A. Miller, and E. Wingate 
2007 Summary Report for Cultural Resources Inventory of Oklahoma Portions of the Continental Connector Pipeline Project: Survey Section 2 and Sherman and Red River Laterals, Bryan, Choctaw, and McCurtain Counties, Oklahoma. Report No. 2006-599. SWCA Environmental Consultants, Austin.

Lawton, S. P.

1956 A Burial in McCurtain County, Oklahoma. Bulletin of the Texas Archeological Society 27:185-194.

1962 Test Excavations at the George Smith-I Site, Choctaw County, Oklahoma. Bulletin of the Oklahoma Anthropological Society 10:153-162.

Leader, P. M.

1997 Chipped Stone Artifacts from the Mackey Site, a Large Black Midden Mound in the Fourche Maline Valley. Master's thesis, Department of Anthropology, University of Oklahoma, Norman.

Lee, C.

1997 Paleopathology of the Hatchel-Mitchell-Moores Sites, Bowie County, Texas. Bulletin of the Texas Archeological Society 68:161-177.

1999 Origins and Interactions of the Caddo: A Study in Dental and Cranial Nonmetric Traits. Master's thesis, Department of Anthropology, Arizona State University.

Lee, D. B.

2009 Caroline Dorman, 1888-1981: Louisiana's Cultural Conservator. In Louisiana Women: Their Lives and Times, edited by J. Allured and J. F. Gentry, pp. 253-269. University of Georgia Press, Athens.

Lee, D. B. (editor)

2001 Regional Variation and Protohistoric Identity: A Round Table Discussion from the 43rd Caddo Conference. Caddoan Archeology 12(2/3):10-35.

Lees, W. B., R. D. Mandel, and P. E. Brockington, Jr.

1982 A Cultural Resources Inventory of Corps of Engineers Land in Oklahoma. Cultural Resources Report No. 5. Soil Systems, Inc., Topeka, Kansas.

Lehmer, D. J.

1952 The Turkey Bluff Focus of the Fulton Aspect. American Antiquity 17(4):313-318.

Leith, L. 
2006 The McCutchan-McLaughlin Site: A Stratigraphic Study of Material Culture Change and Possible Adoption of Horticulture. Master's thesis, Department of Anthropology, University of Oklahoma, Norman,

2009 Evidence of Fourche Maline Sites in the Arkansas River Drainage, Oklahoma. Oklahoma Archeology 57: 1-12.

2010 Fourche Maline Dig. Trowel Marks, The Oklahoma Anthropological Society Quarterly News 2(2):8-9.

2011 A Re-Conceptualization of the Fourche Maline Culture: The Woodland Period as a Transition in Eastern Oklahoma. Ph.D. dissertation, Department of Anthropology, University of Oklahoma, Norman.

2014 Towards a Common Understanding: A Revision of Fourche Maline Chronology in Oklahoma. Caddo Archeology Journal 24:5-28.

Lemley, H. J.

1936 Discoveries Indicating a Pre-Caddo Culture on Red River in Arkansas. Bulletin of the Texas Archeological and Paleontological Society 8:25-55.

1942 Prehistoric Novaculite Quarries of Arkansas. Bulletin of the Texas Archeological and Paleontological Society 14:32-37.

Lengyel, S. N.

2004 Archaeomagnetic Research in the U. S. Midcontinent. Ph.D. dissertation, University of Arizona, Tucson.

Lewis, G. A.

1987 The Clements Brothers' Farm Site, 41CS25. Master's thesis, Department of Anthropology, The University of Texas at Austin.

Lewis, K. E.

1973 Archaeological Investigations at Ch-37, Choctaw County, Oklahoma. Miscellaneous Site Report, Oklahoma River Basin Survey Project, University of Oklahoma, Norman.

Lewis, K. E. (editor)

1975 Fort Washita from Past to Present: An Archaeological Report. Series in Anthropology No. 1. Oklahoma Historical Society, Oklahoma City.

Lindemuth, J., J. Dendy, P. Barrow, P. Heinrich, C. Welch, R. Wilson, and S. Newman

2008 Phase I Cultural Resources Survey I-69 SIU 15, US 171 to I-20, DeSoto, Caddo, and Bossier Parishes, Louisiana. Gulf South Research Corporation, Baton Rouge. 
Lindemuth, J., B. Somers, and C. Welch

2009 Archeological Survey and Backhoe Testing for a Proposed Armed Forces Reserve Center Near Arkadelpha, Clark County, Arkansas. Gulf South Research Corporation, Baton Rouge.

Linder-Linsley, S. E. and L. D. Lindsay

1997 Cultural Resources Survey 1996. Wright Patman Lake and Lake O' the Pines, Bowie, Cass, and Marion Counties, Texas. LL Consultants, Dallas and Atlanta, Texas.

Lintz, C.

1978 An Archaeological Survey of the Kerr-McGee Choctaw Coal Mine Facility Haskell County, Oklahoma. Project Report Series No. 2. Archaeological Research and Management Center, The University of Oklahoma, Norman.

1978 A Radiocarbon Date from 34Hs-111, The Thorny Channel Site, Haskell County, Oklahoma. Oklahoma Anthropological Society Newsletter 26(7):59.

1985 Radiocarbon Dates from the Griffith Site, 34Jn-67. Oklahoma Anthropological Society Newsletter 33(8):2-3.

1995 Section 3.2 Cultural Resource Management. In Environmental Compliance Assessment System (ECAS) Environmental Compliance Assessment Report No. 43-21-2976-95: Joint Readiness Training Center and Fort Polk, Louisiana, July 10-26, 1995, pp. 3-11 to 3-31. U.S. Army Center for Health Promotion and Preventative Medicine, Aberdeen Proving Grounds, Maryland.

2008 Geoarchaeological Testing at Site 41MX29, White Oak Creek Wildlife Management Area, Morris County, Texas. Wildlife Division, Texas Parks and Wildlife Department, Austin.

2009 White Oak Creek Wildlife Management Area, Morris County, Texas: Road realignment (Geoarchaeological Assessment at 41MX29). In Cultural Resource Program 2008 Annual Report, edited by R. Mahoney, pp. 143162. Texas Parks and Wildlife Department, Cultural Resources Program, Austin, Texas.

Lintz, C. and F. Largent, Jr.

2005 Note on a Possible Chipped Stone Grubbing Tool from Upshur County, Texas. Caddoan Archaeology Journal 14:71-73.

Lintz, C. and A. Tine

2008 Two Painted Shelters: 34LF1348 and 34LF1349 in LeFlore County, Oklahoma. Oklahoma Archeology 56(2):13- 21. 
Lintz, C. and R. Vehik

1986 the Archeology of Impoundment 16, Lower Clear Boggy Creek Watershed, Johnston County, Oklahoma. Archaeological Research Report No. 13. Oklahoma Conservation Commission, Oklahoma City.

Lintz, C., F. Largent, T. K. Perttula, V. Dongarra, M. Prior, and M. Huhnke 2007 National Register Evaluative Testing at Prehistoric Sites 16BO450, 16BO458, and 16BO473, Barksdale Air Force Base, Bossier Parish, Louisiana. Report of Investigations, No. 37. United State Air Force Air Combat Command Series. Geo-Marine, Inc., Plano, Texas.

Lippert, D. T.

1997 A Combination of Perspectives on Caddo Indian Health. Ph.D. dissertation, Department of Anthropology, The University of Texas at Austin.

2006 Building a Bridge to Cross a Thousand Years. The American Indian Quarterly 30(3\&4):431-440.

Lippert, D. T., S. Feinstein, and J. C. Dudar

2011 Inventory and Assessment of Human Remains from the Belcher Site, Caddo Parish, Louisiana, in the Collections of the National Museum of Natural History, Smithsonian Institution. Repatriation Office, National Museum of Natural History, Smithsonian Institution, Washington, D.C.

Lisk, S. V.

1984 Ceramics from the Whelan Site: A Temporal and Functional Analysis of a Late Caddoan Mound Site Assemblage. Master's thesis, Department of Anthropology, The University of Texas at Austin.

Livingood, $\mathrm{P}$.

2016 Review of "Caddo Connections: Cultural Interactions within and beyond the Caddo World," by J. S. Girard, T. K. Perttula, and M. B. Trubitt.

American Antiquity 81(4):771-772.

Lockhart, J. J.

2007 Prehistoric Caddo of Arkansas: A Multiscalar Examination of Past Cultural Landscapes. Ph.D. dissertation, Department of Environmental Dynamics, University of Arkansas, Fayetteville.

2010 Tom Jones (3HE40): Geophysical Survey and Spatial Organization at a Caddo Mound Site in Southwest Arkansas. Southeastern Archaeology 29(2):236-249. 
2012 Spatial Patterns of Caddo Mound Sites in the West Gulf Coastal Plain of Arkansas. In The Archaeology of the Caddo, edited by T. K. Perttula and C. P. Walker, pp. 313-334. University of Nebraska Press, Lincoln.

Lockhart, J. J. and T. J. Green

2006 The current and potential role of archaeogeophysics in Cultural Resource Management in the United States. In Remote Sensing in Archaeology: An Explicitly North American Perspective, edited by J. K. Johnson, pp. 17-32. University of Alabama Press, Tuscaloosa.

Lockhart, J. J., J. E. Hilliard, G. Sabo III, and D. A. Weddle

1995 The Evolution of Human Ecosystems in the Ozark National Forest: A Pilot Study of the Lee Creek Unit. Project Report No. 876. Arkansas Archeological Survey, Fayetteville.

Lohse, J. C., with contributions by T. K. Perttula and R. A. Ricklis 2004 Interim Report on Archaeological Testing at 41AN38 and 41AN159, Anderson County, Texas. Coastal Environments, Inc., Corpus Christi.

2005 National Register Eligibility of the Weaver Creek Site, 41BW692, Bowie County, Texas. Archeological Studies Program, Report No. 69. Texas Department of Transportation, Environmental Affairs Division, Austin, and Coastal Environments, Inc., Baton Rouge and Corpus Christi.

Lopez, D. R.

1973 The Wybark Site: A Late Prehistoric Village Complex in the Three Forks Locale, Muskogee County, Oklahoma. Bulletin of the Oklahoma Anthropological Society 22:11-126.

Lopez, D. R. and K. D. Keith (editors)

1976 An Archaeological Survey of U. S. 69, Pittsburgh, Atoka and Bryan Counties, Oklahoma. Papers in Highway Archaeology No. 2. Oklahoma Highway Archaeological Survey, Norman.

Lopinot, N. H. and G. S. Powell

2012 Archaeobotanical Analysis. In Archaeological Data Recovery at Foster Place (3LA27) and Site 3LA290 for the Red River Rehabilitation Project (Item 9A-2), Lafayette County, Arkansas, by C. A. Buchner, K. Oesch, N. H. Lopinot, G. S. Powell, C. P. Walker, J. Rocco de Gregory, N. P. Hermann, and S. L. Scott, pp. 221-237. PCI Report 31053. Panamerican Consultants, Inc., Memphis, Tennesseee.

Lorrain, D. and N. Hoffrichter

1968 Archeological Survey and Excavation at Pat Mayse Reservoir, Texas. Archaeological Salvage Project, Southern Methodist University, Dallas. 
Love, L. B.

2014 Petrographic Analysis of Pottery from the Willow Chute Locality and Other Sites in Northwest Louisiana. Report on file, Northwest State University of Louisiana, Natchitoches.

Love, L. B., S. A. Tomka, and T. K. Perttula

2015 The Petrographic Analysis of Sherds from the Craig Mound at the Spiro Site (34Lf40), the Moore \#3/Ainsworth Site (34Lf31), andf the Geren Site (34Lf36), LeFlore County, Oklahoma. Caddo Archeology Journal 25:5-47.

Loveland, C. J.

1980 The Skeletal Biology of the Caddo Indians of the Kaufman-Williams Site, Red River County, Texas. Ph.D. dissertation, Department of Anthropology, University of Tennessee, Knoxville.

1987 Human Skeletal Remains from the Clark and Holdeman Sites, Red River County, Texas. Bulletin of the Texas Archeological Society 57:165-181.

1994 Vertebral Anomalies and Degenerative Lesions in the Caddoan Skeletal Population, Kaufman-Williams Site, Red River County, Texas. Bulletin of the Texas Archeological Society 65:161-181.

1994 Rowland Clark and Dan Holdeman Site Human Skeletal Remains. Journal of Northeast Texas Archaeology 4:50-60.

Loveland, C. J. and W. M. Bass

1983 Human Skeletal Remains from the Williams Site. In Archaeological Research at the Bob Williams Site (41RR16), Red River County, Texas, by G. Perino, pp. 85-144. Museum of the Red River, Idabel.

1983 Cranial Studies of the Caddo Indians from the Kaufman-Williams Site. In Southeastern Natives and Their Pasts, edited by D. G. Wyckoff and J. L. Hofman, pp. 241-257. Studies in Oklahoma's Past No. 11. Oklahoma Archeological Survey, Norman.

Loveland, C. J. and J. B. Gregg

1988 Brachydactyly in a Prehistoric Texas Skeleton. Plains Anthropologist 33(2):399-404.

Loveland, C. J., J. B. Gregg, and W. M. Bass

1984 Osteochondritis Disecans from the Great Plains of North America. Plains Anthropologist 29:239-246.

1984 Ancient Osteopathology from the Caddoan Burials at the KaufmanWilliams Site, Texas. Plains Anthropologist 30(107):29-43. 
Lunday, E.

2014 Rethinking Spiro Mounds. American Archaeology 18(3):26-32.

2015 The Road to Prehistory. American Archaeology 19(4):19-25.

Lyons, E. A.

1996 A New Deal for Southeastern Archaeology. University of Alabama Press, Tuscaloosa.

Lysobey, M. B.

2007 Caddo Indian Memorial. The Encyclopedia of Arkansas History \& Culture, http://www.encyclopediaofarkansas.net/encyclopedia/entrydetail.aspx?search=1\&entrylD=4105.

MacDonald, K. C. and D. W. Morgan

2012 African Earthen Structures in Colonial Louisiana: Architecture from the Coincoin Plantation (1787-1816). Antiquity 86:161-177.

Madden, M. R.

1985 A Class III Cultural Resources Inventory and Assessment of the Proposed TXO Turman \#1 Well Location and Access Road, Spiro Bottoms, LeFlore County, Oklahoma. Report prepared for TXO Production Corp. by Heartfield, Price and Greene, Inc., Monroe, Louisiana.

Mahoney, R., C. Crawford, R. Mauldin, L. Nordt, T. K. Perttula, and S. Reyna 2001 Camp Maxey III, Archaeological Testing of 23 Prehistoric Sites, Lamar County, Texas. Archaeological Survey Report No. 314. Center for Archaeological Research, The University of Texas at San Antonio.

Mahoney, R. B., S. A. Tomka, J. Weston, and R. Mauldin

2002 Camp Maxey IV: Archaeological Testing of Six Sites, Lamar County, Texas. Archaeological Survey Report No. 326. Center for Archaeological Research, The University of Texas at San Antonio.

Mainfort, R. C., Jr.

2008 Sam Dellinger: Raiders of the Lost Arkansas. University of Arkansas Press, Fayetteville.

Mainfort, R. C., Jr., M. M. Evans, and J. S. Pebworth

2002 A Phase I Cultural Resources Survey of the Proposed City of Fayetteville Wastewater Treatment Facility Site, Associated Water Lines and Lift Stations, and the Proposed Extension of Broyles Road, Washington County, Arkansas. Final Report, Projects 02-14 and 02-16. Arkansas Archeological Survey, Fayetteville.

Maki, D. and R. C. Fields 
2010 Multisensor Geophysical Survey Results from the Pine Tree Mound Site: A Comparison of Geophysical and Excavation Data. Southeastern Archaeology 29(2):292-309.

Mallouf, M. G.

1979 Archeological Investigations at Lake Limestone, Fall and Winter 1977. Research Report No. 71. Texas Archeological Survey, The University of Texas at Austin.

Mallouf, R. J.

1976 Archeological Investigations at Proposed Big Pine Lake, 1974-1975: Lamar and Red River Counties, Texas. Archeological Survey Report No. 18. Office of the State Archeologist, Texas Historical Commission, Austin.

Malone, J. M.

1972 Archaeological Reconnaissance at Proposed Mineola Reservoir. Archeological Survey Report No. 10. Texas Historical Survey Committee, Austin.

Mann, D. K.

2007 Articulation of bone identification wth Native American beliefs, civil authority, and military installation management. Federal Facilities Environmental Journal 11(3):105-114.

Mansker, $\mathrm{P}$.

1986 Boatstone from the Fourche Maline Valley. Oklahoma Anthropological Society Newsletter 34(4):7.

Maples, W. R.

1962 A Morphological Comparison of Skeletal Material from Sanders Focus and from Fulton Aspect. Master's thesis, Department of Anthropology, The University of Texas at Austin.

Marceaux, P. S.

2007 Recent Research on the Archaeological and Historical Evidence of the Hasinai. Journal of Northeast Texas Archaeology 26:82-98.

2011 The Archaeology and Ethnohistory of the Hasinai Caddo: Material Culture and the Course of European Contact. Ph.D. dissertation, Department of Anthropology, The University of Texas at Austin.

Marceaux, P. S. and T. K. Perttula

2010 Negotiating Borders: The Southern Caddo and Their Relationships with Colonial Governments in East Texas. In American Indians and the Market Economy, 1775-1850, edited by L. Greene and M. R. Plane, pp. 80-97. University of Alabama Press, Tuscaloosa. 
Marceaux, P. S. and M. F. Wade

2014 Missions Untenable: Experiences of the Hasinai Caddo and the Spanish in East Texas. In Indigenous Landscapes and Spanish Missions: New Perspectives from Archaeology and Ethnohistory, edited by L. M. Panich and T. D. Schneider, pp. 57-75. University of Arizona Press, Tucson.

Marchbanks, M. L.

1989 Lipid Analysis in Archaeology: An Initial Study of Ceramics and Subsistence at the George C. Davis Site. Master's thesis, Department of Anthropology, The University of Texas at Austin.

Margolis, M., S. Ahr, C. von Wedell, M. Davenport, S. Hartsfield, D. Kapanday, M. Meier, and K. Cox

2014 Archaeological Data recovery at Site 34CO29, Coal County, Oklahoma. URS Corporation, Dallas.

Markell, A., R. Draughton, Jr., S. B. Smith, J. Cohen, P. Heinrich, S. Hinks, and W. E. Athens

1995 Cultural Resources Survey at Loggy Bayou Mitigation Lands, Bossier Parish, Louisiana. R. Christopher Goodwin \& Associates, Inc., New Orleans.

Martin, W. A.

1982 An Intensive Archeological Survey of a Barite Mining District in Montgomery County, Arkansas. In Fancy Hill Archeological Studies in the Southern Ouachita Mountains, edited by A. M. Early and W. F. Limp, pp. 1-182. Research Series No. 16. Arkansas Archeological Survey, Fayetteville.

Martin, W. A., and others

1990 Archeological Bibliography for the Northeastern Region of Texas. Cultural Resource Management Report 1, Department of Antiquities Protection, and Special Report 32, Office of the State Archeologist, Texas Historical Commission, Austin.

Mayes, A. T.

1996 The Dental Anthropology of the Spiro Mounds of Oklahoma. Master's thesis, Department of Anthropology, University of Oklahoma, Norman.

2001 Patterns Through Time: Interactions between Changes in Subsistence and Human Dentition at Illinois Bluff, Jersey County, Illinois, and Spiro Mounds, Oklahoma. Ph.D. dissertation, Department of Anthropology, University of Colorado, Boulder.

Mayo, M. B. 
1974 Survey Work at Wister Lake. Oklahoma Anthropological Society Newsletter 22(7):5.

1975 A Resurvey and Assessment of the Prehistoric Resources of Wister Lake, LeFlore County, Oklahoma. General Survey Report No. 14. Oklahoma River Basin Survey Project, University of Oklahoma Office of Research Administration, Norman.

1979 A Survey and Assessment of the Cultural Resources in Selected Portions of the Ozark Gas Transmission System, Eastern Oklahoma. Project Report Series No. 5. Archaeological Research and Management Center, The University of Oklahoma, Norman.

Mayo, M. and G. R. Muto

1979 Radiocarbon Dates for Lee's Creek Region, Eastern Oklahoma. Oklahoma Anthropological Society Newsletter 27(4):10-13.

McClurkan, B.

1984 Archeological Testing at Site 3MN25, AHTD Job Number S-49-10, Montgomery County. Arkansas Highway and Transportation Department, Environmental Division, Little Rock.

McClurkan, B. B., W. T. Field, and J. N. Woodall

1966 Excavations in Toledo Bend Reservoir, 1964-65. Papers of the Texas Archeological Salvage Project No. 8. Texas Archeological Salvage Project, The University of Texas at Austin.

McClurkan, B. B., E. B. Jelks, and H. P. Jensen

1980 Jonas Short and Coral Snake Mounds: A Comparison. In "Caddoan and Poverty Point Archaeology: Essays in Honor of Clarence Hungerford Webb, edited by J. L. Gibson. Louisiana Archaeology 6:173-206.

McCormick, O. F., III

1973 The Archaeological Resources in the Lake Monticello Area of Titus County, Texas. Contributions in Anthropology No. 8. Department of Anthropology, Southern Methodist University, Dallas.

1973 Lake Swauano: An Archaeological Reconnaissance. Archaeology Research Program, Southern Methodist University, Dallas.

1974 Archaeological Excavations at Lake Monticello. Archaeology Research Program, Southern Methodist University, Dallas.

McCrocklin, C.

1984 Some Preliminary Observations on Sites and Site Distributions in the Great Bend Region, Southwest Arkansas: A Field Report on Projects 
SAU-29 and SAU-31. Field Notes (Arkansas Archeological Society) 201:36.

1985 Potter's Pond: A Caddo Salt and Pottery Making Site. Field Notes (Arkansas Archeological Society) 202:3-4.

1985 An Interim Report (25 March 1985) on a Surface Survey of the Mounds Plantation Site (16CD12). Field Notes (Arkansas Archeological Society) 205:13-17.

1986 A Surface Survey of Egypt Mounds (3LA23) and Vicinity. Field Notes (Arkansas Archeological Survey) 210:3-5.

1991 The Search for Crenshaw Mounds Satellite Sites. Field Notes (Newsletter of the Arkansas Archeological Society) 242:5-6.

1991 The Search for Crenshaw Mounds Satellite Sites: Preliminary Report. Field Notes (Newsletter of the Arkansas Archeological Society) 243:9-10.

1992 Report on Test Excavations by the Adais Caddo at a Caddoan Mound in Caddo Parish. Caddoan Archeology Newsletter 3(2):12-13.

1992 Test of a Caddo Mound in Northern Louisiana. Field Notes (Newsletter of the Arkansas Archeological Society) 247:14.

1992 An Intermediate Report on the James Bayou Survey, Marion County, Texas: A Search for Caddo Village. Caddoan Archeology Newsletter $3(3): 17-20$.

1998 Preliminary Report on the James Bayou Survey: A Search for Sha-Childni$\mathrm{Ni}$ (1795-1840). Caddoan Archeology 9(1):11-19.

McDonald, A. J.

1972 An Archeological Survey of the Martin Lake Area, Rusk and Panola Counties, Texas. Research Report No. 14. Texas Archeological Salvage Project, The University of Texas at Austin.

McGimsey, C. R. and H. A. Davis

1965 Survey of the DeGray Reservoir Area. The Arkansas Archeologist 6(1):1419.

McGimsey, C. R. and J. van der Koogh

2001 Louisiana's Archaeological Radiometric Database. Special Publications of the Louisiana Archaeological Society No. 3. 
McGimsey, C., J. Girard, J. Bradley, R. Cornett, P. Dickson, S. Kavanaugh, R. Kavanaugh, and K. McKneely

2017 Discovery and Recovery of a Prehistoric Dugout Canoe at Site 16CD383. Newsletter of the Louisiana Archaeological Society 45(2):9-13.

McGregor, D. E., M. M. Green, D. H. Jurney, W. A. Martin, R. W. Moir, and J. W. Saunders

1996 Archaeological Investigations at Cooper Lake, Delivery Orders Numbers 2, 3 \& 4, 1987. 2 Vols. Archaeology Research Program, Southern Methodist University, Dallas.

McGuff, P.

1980 Cultural Resource Survey and Testing at the McGee Creek Project, Oklahoma. Environmental Assessments, Inc., Pauls Valley, Oklahoma.

1993 Testing of Archaeological Sites in the McGee Creek Project Area, Atoka County, Oklahoma. McGee Creek Archaeological Project Reports Vol. II. Institute of Applied Sciences, University of North Texas, Denton.

McHugh, W. P.

1963 A Transitional Archaic and Woodland Site (DI-37) in Delaware County, Oklahoma. Master's thesis. Department of Anthropology, University of Wisconsin, Madison.

McIntyre, J., E. Miller, K. Vanderslice, and M. B. Trubitt

2015 New Results on Three Projects from the Survey's HSU Research Station. Field Notes (Newsletter of the Arkansas Archeological Society) 385:3-5.

McKay, D.

1999 Results of a Phase I Cultural Resources Inventory of Two Shallow-Water Impoundment Locations in Henderson County, Texas. Wendy Lopez \& Associates, Dallas.

McKay, D., K. Kahl, S. Gaither, and R. Procter

2002 Cultural Resources Inventory, of 3,230 Acres at Four Lakes in Eastern Kansas and Eastern Oklahoma: Council Grove, Gall River, Heyburn, and Fort Gibson. Wendy Lopez \& Associates, Inc., Dallas.

McKay, D., K. Kahl, and R. Procter

2003 Cultural Resources Inventory at Five Lakes in Eastern Oklahoma and Northeastern Texas: Tenkiller, Eufaula, Fort Gibson, Pat Mayse, and Texoma. Miscellaneous Reports, Reports of Investigations Number 3. Lopez Garcia Group, Dallas.

McKee, A., C. D. Frederick, T. K. Perttula, B. Fullerton, C. Randklev, J. P. Dering, J. R. Ferguson, M. D. Glascock, S. Wolverton, D. Shanabrook, A. 
Naumann, and D. Pleasant

2010 Archaeological Testing and Data Recovery Excavations at Site 41COL172. Miscellaneous Reports of Investigations No. 513. Geo-Marine, Inc., Plano, Texas.

McKee, A., C. D. Frederick, T. K. Perttula, R. Z. Selden, L. Bush, L. Kemp, B. Gregory, C. Yost, L. S. Cummings, J. R. Ferguson, M. D. Glascock, S. Tomka, L. Cecil, C. Masiello, X. Gao, C. Goodmaster, and V. Beasley, III 2015 Data Recovery Investigations: Murvaul Creek Site (41PN175), Panola County, Texas. Report No. 165. Archeological Studies Program, Environmental Affairs Division, Texas Department of Transportation, Austin.

McKinnon, D. P.

2008 An Archaeogeophysical Analysis of Central Caddo Settlement Patterning at Battle Mound (3LA1). Master's thesis, Department of Anthropology, University of Arkansas, Fayetteville.

2009 Exploring Settlement Patterning at a Premier Caddo Mound Site in the Red River Great Bend Region. Southeastern Archaeology 28(2):248-258.

2010 Summer 1948: A Summary of Excavations at Battle Mound (3LA1), A Premier Caddo Mound Site in the Great Bend Region of the Red River. The Arkansas Archeologist 49:1-16.

2010 Continuing the Research: Archaeogeophysical Investigations at the Battle Mound Site (3LA1) in Lafayette County, Arkansas. Southeastern Archaeology 29(2):250-260.

2011 Foreword: A Review of Woodland and Caddo Archeology in Arkansas. In Archeology in Arkansas: Selected Articles from The Arkansas Archeologist, Bulletin of the Arkansas Archeological Society, Volume 1, Caddo Archeology, assembled by D. P. McKinnon, pp. 5-24. Gustav's Library, Davenport, lowa.

2011 Foster Trailed-Incised: A GIS-Based Analysis of Caddo Ceramic Distribution. Caddo Archeology Journal 21:71-88.

2011 Thirty Years in the Foil: An ARF-Funded AMS Date from Battle Mound (3LA1). Field Notes (Newsletter of the Arkansas Archeological Society) No. 362:6-8.

2012 M. R. Harrington and the Lost Mound in Hempstead County, Arkansas. Caddo Archeology Journal 22:63-77. 
2012 Corn Cobs Collected in 1948: An ARF-Funded AMS Date from Battle Mound (3LA1). Field Notes (Newsletter of the Arkansas Archeological Society) No. 368:8-9.

2013 Landscape as a Ritual Object: Exploring Some Thoughts on Organized Space in the Great Bend Region of Southwestern Arkansas. Caddo Archeology Journal 23:67-84.

2013 Making Headway: Another ARF-Funded AMS Date from Battle Mound (3LA1). Field Notes (Newsletter of the Arkansas Archeological Society) No. 372:9-10.

2013 Battle Mound: Exploring Space, Place, and History of a Red River Caddo Community in Southwest Arkansas. Ph.D. dissertation, Department of Anthropology, University of Arkansas, Fayetteville.

2014 A Salvage along the Red River: An ARF-Funded AMS Date from the Red Cox Site (3LA18). Field Notes (Newsletter of the Arkansas Archeological Society) No. 381:3-4.

2015 Zoomorphic Effigy Pendants: An Examination of Style, Medium, and Distribution in the Caddo Area. Southeastern Archaeology 34(2):116-135.

2015 Battle Mound Site. In The Encyclopedia of Arkansas History \& Culture, http://www.encyclopediaofarkansas.net/encyclopedia/entrydetail.aspx?entrylD=8340.

2016 Report on Magnetic Gradient Surveys at Four Caddo Sites in East Texas. University of Central Arkansas, Conway.

2016 Distribution of Design: The Rayed Circle. Caddo Archeology Journal 26:29-42.

2017 A Report on a Long Term Research Program on the Bowman Site in Arkansas. Caddo Archeology Journal 27:96-97.

2017 A Short Report and Request on Building a Canine Burial Corpus. Caddo Archeology Journal 27:98-99.

2017 Report on Magnetic Gradient Survey at Three Caddo Sites in East Texas. Journal of Northeast Texas Archaeology 72:169-175.

2017 The Battle Mound Landscape: Exploring Space, Place, and History of a Red River Caddo Community in Southwest Arkansas. Research Series No. 68. Arkansas Archeological Survey, Fayetteville. 
McKinnon, D. P. (assembler)

2011 Archeology in Arkansas: Selected Articles from The Arkansas Archeologist, Bulletin of the Arkansas Archeological Society, Volume 1, Caddo Archeology. Gustav's Library, Davenport, lowa.

McKinnon, D. P. and J. C. Brandon

2009 A Report from the Field: Archaeogeophysical Results from Battle Mound (3LA1). Field Notes (Newsletter of the Arkansas Archeological Society) 348:9-12.

2014 Sometimes Things Just happen: A Small Hempstead Engraved Bottle Finds a Site. Field Notes (Newsletter of the Arkansas Archeological Society) 378:10-11

McKinnon, D. P. and B. S. Haley

2017 Evaluating the Use of Community Space at Two Southeastern Mound Centers Using Magnetic Gradient and Surface Collection Data. In Archaeological Remote Sensing in North America: Innovative Techniques for Anthropological Application, edited by D. P. McKinnon and B. S. Haley, pp. 46-64. University of Alabama Press, Tuscaloosa.

McKinnon, D. P., R. Nguyen, T. Yeager, and L. L. Bush

2017 Salvage along the Red River: The Red Cox (3LA18) Site and its Place on the Caddo Landscape. Caddo Archeology Journal 27:36-50.

McKinnon, D. P., T. K. Perttula, and A. McKee

2017 Magnetic Gradient Survey at the M. S. Roberts (41HE8) Site in Henderson County, Texas. Journal of Northeast Texas Archaeology 71:165-174.

McManus, J. W.

1963 The McElroy Site: A Coles Creek-Caddoan Transitional Site in Union County, Arkansas. The Arkansas Archeologist 4(3):1-7.

McWilliams, R. K.

1968 Skeletal Material from the Site Mc-84, McCurtain County, Oklahoma. Bulletin of the Oklahoma Anthropological Society 16.

1970 Physical Anthropology of Wann and Sam: Two Fourche Maline Focus Archaic Sites in Eastern Oklahoma. Bulletin of the Oklahoma Anthropological Society 19:101-136.

McWilliams, J. K., R. C. Fields, and M. D. Freeman 2004 Survey of 613 Acres, Sabine Mine Area Q, Harrison County, Texas. Technical Reports No. 71. Prewitt and Associates, Inc., Austin.

McWilliams, J. K., K. W. Kibler, J. E. Dockall, E. F. Gadus, and R. C. Fields 
2014 Eligibility Testing at 41BU75, Burleson County, Texas (CSJ No. 0648-03046). Archeological Studies Program, Report No. 159, Environmental Affairs Division, Texas Department of Transportation and Technical Reports No. 96, Prewitt \& Associates, Inc., Austin.

Mehalchick, G. and K. W. Kibler

2008 Hunters and Gatherers of the North Bosque River Valley: Excavations at the Baylor, Britton, McMillan, and Higginbotham Sites, Waco Lake, Mclennan County, Texas. Reports of Investigations No. 156. Prewitt and Associates, Inc., Austin.

Melrose, B.

1978 Incised Feline Jawbones, LeFlore County, Oklahoma. Oklahoma Anthropological Society Newsletter 26(7):3-4.

1981 Some Oklahoma Boatstones. Oklahoma Anthropological Society Newsletter 29(9):5-6.

1981 An Embossed Copper Artifact from Spiro. Oklahoma Anthropological Society Newsletter 29(6):12.

Meroney, W. E.

1936 A Mass Burial near Waco. Central Texas Archeologist 2:58-60.

Merriam, L. and C. Merriam

2004 The Spiro Mound: A Photo Essay. Merriam Station Books, Oklahoma City.

Mickle, W. R.

1994 An Historic Caddo Indian Village (Hasinai) in East Texas. The Amateur Archaeologist 1(1):82-83.

Middlebrook, T. A.

1993 Radiocarbon Dates from the Tyson Site (41SY92). Caddoan Archeology Newsletter 3(4):2-8.

1994 An Update of Archaeological Investigations at the Tyson Site. Journal of Northeast Texas Archaeology 3:1-36.

1997 The Caddoan Occupation of the Attoyac and Angelina River Basins in the Middle Caddoan Period. Journal of Northeast Texas Archaeology 10:3640.

1997 Notes on Caddoan Vessels Collected from the Mosquito Island Site (41AG66), Lake Sam Rayburn. Journal of Northeast Texas Archaeology 10:59-63. 
2007 A Survey of Historic Caddo Sites in Nacogdoches County. Journal of Northeast Texas Archaeology 26:99-115.

2010 The Jack Walton Site (41SA135), San Augustine County, Texas. Journal of Northeast Texas Archaeology 33:1-23.

2014 Early European Descriptions of Hasinai Elites and Understanding Prehistoric Caddo Mortuary Practices in Shelby County, Texas. Bulletin of the Texas Archeological Society 85:83-110.

Middlebrook, T. and R. Middlebrook

1996 Of Hearths and Houses. Caddoan Archeology Newsletter 6(4):11-22.

Middlebrook, T. and T. K. Perttula

1997 The Middle Caddoan Period in East Texas: A Summary of the Findings of the East Texas Caddoan Research Group. Journal of Northeast Texas Archaeology 9:1-8.

2008 Archaeological Investigations at the Henry M. Site (41NA60): An Early Historic Caddo Farmstead in Nacogdoches County, Texas. Journal of Northeast Texas Archaeology 28:13-20.

Miller, A. F.

1977 Rescue Excavations at the Bruner Site, Hs-74, Haskell County, Oklahoma. Oklahoma Anthropological Society Newsletter 25(5):2-7.

1977 A Survey and Assessment of the Cultural Resources of the McClellan-Kerr Arkansas River Navigation System in Oklahoma, 1976. Archeological Resources Survey Report No. 6. Oklahoma Archeological Survey, Norman.

Miller, C. G., C. Davies, R. Draughton, Jr., S. B. Smith, J. Horowitz, M. Williams, J. A. Green, and B. Kemp

1998 Cultural Resources Investigations of Pool 5 Inundation Lands, Red River Waterwa, y Bossier and Caddo Parishes, Louisiana. 3 Vols. R. Christopher Goodwin and Associates, Inc., New Orleans.

Miller, E. O. and E. B. Jelks

1952 Archeological Excavations at the Belton Reservoir, Coryell County, Texas. Bulletin of the Texas Archeological and Paleontological Society 23:168217.

Miller, J.

1963 Radiocarbon Dates from Oklahoma and Surrounding Areas. Bulletin of the Oklahoma Anthropological Society 11:115-121. 
Miller, J. E., III

1984 The Role of Salt in Shell-Tempered Pottery Production. Field Notes (Newsletter of the Arkansas Archeological Survey) 198:3-5.

1985 Further Archeological Investigations at 3SA155: An Addendum to AHTD Job \#60342. Arkansas Highway Transportation Department, Little Rock.

1986 The Myers Mound: Salvage Excavations at a Caddo II Site in Southwest Arkansas. The Arkansas Archeologist 23/24:67-127.

1986 Archeological Survey and Testing of the Proposed Saline Bayou Bridges and Approaches, Clark County, Arkansas. Arkansas Highway Transportation Department, Little Rock.

1986 Archeological Survey and Testing of the Proposed Saline Bayou Bridge and Approaches, Clark County, Arkansas, AHTD Job \# 7846. Arkansas Highway and Transportation Department, Environmental Division, Little Rock.

1991 An Archeological Survey of the Proposed Red River Bridge and Approaches (Spring Bank), Miller and Lafayette Counties, Arkansas, AHTD Job \# 1575. Arkansas Highway and Transportation Department, Environmental Division, Little Rock.

1991 Test Excavations at the Couch Site (3PI98), Pike County, Arkansas. Arkansas Highway and Transportation Department, Environmental Division, Little Rock.

1992 A Cultural Resources Survey of Three Timber Management Areas in Garland and Montgomery Counties, Arkansas. U.S. Army Corps of Engineers, Lake DeGray Field Office.

1992 A Cultural Resources Survey of Four Timber Management Areas in Clark and Hot Springs Counties, Arkansas. U.S. Army Corps of Engineers, Lake DeGray Field Office.

1993 A Cultural Resources Survey of Proposed Arkansas Highway and Transportation Department Job \# BR-30-3, Ouachita River Structure and Approaches, Hot Spring County, Arkansas. Arkansas Highway and Transportation Department, Environmental Division, Little Rock.

1994 A Cultural Resources Survey of Proposed Arkansas Highway and Transportation Department Job 020178, Grant County. Arkansas Highway and Transportation Department, Environmental Division, Little Rock. 
1995 A Cultural Resources Survey of Proposed Arkansas Highway and Transportation Department Job 020182, Grant County. Arkansas Highway and Transportation Department, Environmental Division, Little Rock.

1996 A Cultural Resources Survey of Arkansas Highway and Transportation Department Job Number FA3009, Ouachita River Structure and Approaches No. 2, Hot Spring County, Arkansas. Arkansas Highway and Transportation Department, Environmental Division, Little Rock.

2002 A Cultural Resources Survey of AHTD Job \# R80103 Illinois Bayou Structures and Approaches Pope County, Arkansas, AHTD Job \# R80103. Arkansas Highway and Transportation Department, Environmental Division, Little Rock.

2011 Some Notes on Replicating Prehistoric Pottery. Caddo Archeology Journal 21:5-28.

Miller, M., N. Steinle, K. Korfmacher, D. Sitters, D. Rose, and K. Stone 2014 Cultural Resource Survey of the Proposed Tarrant Regional Water District/City of Dallas Integrated Pipeline Project in Tarrant, Johnson, Ellis, Navarro, Henderson, and Anderson Counties, and Expansion of the Kennedale Balancing Reservoir in Tarrant County, Texas. AmaTerra Environmental, Inc., Austin.

Milner, G. R., D. G. Anderson, and M. T. Smith

2001 The Distribution of Eastern Woodlands Peoples at the Prehistoric and Historic Interface. In Societies in Eclipse: Archaeology of the Eastern Woodlands, A.D. 1400-1700, edited by D. S. Brose, C. W. Cowan, and R. C. Mainfort, Jr., pp. 9-18. Smithsonian Institution Press, Washington, D.C.

Minich, F. J.

1994 The Art of the Spiro Warrior: Engravings in Shell from the Spiro Site. Master's thesis, University of Georgia at Athens, Athens, Georgia.

Mintz, J. J.

1989 Prehistoric Ceramic Variability in the Arkansas Ozarks. Master's thesis, Department of Anthropology, University of Arkansas, Fayetteville.

Mires, A. M. W.

1983 A Bioarchaeological Study of the Adaptive Efficiency of the Caddo. Master's thesis, Department of Anthropology, University of Arkansas, Fayetteville.

Miroir, M. E., R. K. Harris, J. C. Blaine, and J. McVay 
1973 Bernard de la Harpe and the Nassonite Post. Bulletin of the Texas Archeological Society 44:113-167.

Mitchell, S. A.

2000 Data Salvage Project: Greasy Creek Study. Report on file, Texas Archeological Research Laboratory, The University of Texas at Austin.

Moerbe, A. and T. Gannon

2000 Phase II Testing of Two Sites (3MI355, 3MI378) between County Road 10 and Fouke, Miller County, Arkansas. Burns and McDonnell, Kansas City.

Moerbe, A. and M. A. Latham

1998 Phase I Archaeological Survey for the Clarksville to Chambers Spring 345 kV Transmission Line, Clarksville Substation to the Boudinot Substation in Wagoner and Cherokee Counties, Oklahoma. Report prepared for Southwestern Electric Power Company by Burns \& McDonnell, Kansas City.

Moerbe, A. L., C. S. Spears, C. Catlin, C. M. Baker, C. A. Johnson, L. Porter, and B. Wick

1998 An Archeological Survey of the Proposed Interstate 71 from Texarkana, Arkansas to the Louisiana State Line, Miller County, Arkansas. Project Report 98. Spears Professional Environmental and Archeological Research Service, Inc., West Fork, Arkansas.

Mohrman, D.

1939 The Detection of Fraudulent Copper Needles. Transactions of the Illinois Academy of Sciences 32:60-61.

Mooney, J. and S. Mooney

1999 US 71 Relocation, I-40 in Alma to Rye Hill; 1998 Archeological Survey and Phase II Significance Testing. Field Notes (Newsletter of the Arkansas Archeological Society) 286:6.

Mooney, J. and B. A. Jendraszkiewicz

2000 Phase I Archeological Survey of U. S. 71 Relocation: Fort Chaffee Realignment. Michael Baker Jr., Inc., Pine Bluff.

Mooney, J., B. A. Jendraszkiewicz, and S. M. Mooney

2000 Phase I/II Archeological Investigations of U. S. 71 Relocation: DeQueen to I-40 Segments L-O, Volumes 1 and 2. Michael Baker Jr., Inc., Pine Bluff.

Moore, B.

1928 Indian Mounds in Oklahoma. The American Indian 2(14):13. Tulsa.

Moore, C. B. 
1909 Antiquities of the Ouachita Valley. Journal of the Academy of Natural Sciences of Philadelphia 14 (Part 1):7-170.

1912 Some Aboriginal Sites on Red River. Journal of the Academy of Natural Sciences of Philadelphia 14(4):526-636.

Moore, R. G., T. K. Perttula, R. C. Booth, J. M. Sanchez, D. Trial, and W. E. Moore

1996 A Cultural Resources Survey of Four Tracts of Forested Land Around Lake O' the Pines Reservoir in Marion and Upshur Counties in Northeast Texas. Report of Investigations 136. Moore Archeological Consulting, Houston.

Moore, S. D.

1992 Cultural Resource Inventory of Surplus Land, Wallace Lake and Bayou Bodcau Reservoir, Caddo and Bossier Parishes, Louisiana. Panamerican Consultants Inc. Baton Rouge.

Moore, S. K.

1996 Diet and Disease Among the Prehistoric Ouachita Caddo. Honors thesis, Department of Anthropology, University of Arkansas, Fayetteville.

Moore, W. E.

1986 A Holly Fine Engraved Sherd from the Reese Site (41WA55), Walker County, Texas. Journal of the Houston Archeological Society 85:19-21.

1990 The Derrick Adams Site (41WA100), A Late Prehistoric Site in Walker County, Texas. Journal of the Houston Archeological Society 96:11-14.

1997 An Assessment of Prehistoric Site 41WA208 in Walker County, Texas. Brazos Valley Research Associates, Bryan, Texas.

1997 A Cultural Resources Survey of Two Proposed Pump Station Sites on Lake O' the Pines Reservoir in Marion County, Texas. Contract Report 52. Brazos Valley Research Associates, Bryan, Texas.

2003 A Phase I Cultural Resources Survey of the Blocker-Crossroads WSC Water Line Project in Central Harrison County, Texas. Contract Report 103. Brazos Valley Research Associates, Bryan, Texas.

2007 Archeological Survey for the Western Cass Water Supply Corporation Water Improvement Project in Cass and Morris Counties, Texas. Contract Report 186. Brazos Valley Research Associates, Bryan, Texas.

2010 An Archaeological Survey for the Navidad Eastham State Prison Farm Mineral Development Program- Phase II in Houston County, Texas. 
Contract Report No. 247. Brazos Valley Research Associates, Bryan, Texas.

2013 A Report on Four Sites in Madison County (41MA27-41MA30). Contributions in Archaeology No. 3. Brazos Valley Research Associates, Bryan, Texas.

2013 A Cultural Resources Survey for the Tri Special Utility District Water Improvement Project in Franklin, Morris, and Titus Counties, Texas. Contract Report No. 263. Brazos Valley Research Associates, Bryan, Texas.

Moore, W. E. and E. M. Grubb

2011 A Phase 1 Archaeological Survey for Global Geophysical Services, Inc.'s Elm Grove 3-D Seismic Survey on Property Owned by the United States Army Corps of Engineers, Vicksburg District, in Bossier Parish, Louisiana. Contract Report No. 224. Brazos Valley Research Associates, Bryan, Texas.

Moore, W. E., R. D. Fields, and E. P. Baxter

2008 An Archaeological Survey of Seismic Exchange Inc.'s Bodcaw Phase II and III 3-D Seismic Survey within the Kisatchie National Forest, Winn Ranger Ranger District, Natchitoches and Winn Parishes, Louisiana. Brazos Valley Research Associates, Bryan, Texas.

Moore-Jansen, P. H.

1982 Observations of Human Dental Enamel Using Light and Scanning Electron Microscopy as Means for Dietary Reconstruction in Prehistoric Populations: A Study in Experimental Bioarchaeology. Master's thesis, Department of Anthropology, University of Arkansas, Fayetteville

Morehead, J. R., W. R. Mallory, L. J. Campbell, and J. H. Mathews

2005 Cultural Resources Survey Within the Clear Fork Watershed, Ouachita National Forest, Polk and Scott Counties, Arkansas. Prentice Thomas and Associates, Inc., Ft. Walton Beach, Florida.

Morehead, J. R., J. H. Mathews, B. Aubuchon, and L. J. Campbell 2008 Phase I Cultural Resources Survey of an Approximately 105-Acre Tract Proposed for Development, Bossier Parish, Louisiana. Report of Investigations 1132. Prentice Thomas \& Associates.

Moorehead, S. and C. Ewen

1992 Archaeological Testing of the Proposed Red River Bridge and Approaches, 3MI243, Miller and Lafayette Counties, Arkansas. Sponsored Research Program Project 818. Arkansas Archeological Survey, Fayetteville. 
Moorehead, W. K.

1931 The Archaeology of the Arkansas River Valley. Andover Press, Andover, Massachusetts.

Morgan, D. W.

2005 Phase II Archaeological Investigations at the American Cemetery (16NA67), Natchitoches Parish, Louisiana. The Cultural Resources Office, Northwestern State University of Louisiana, Natchitoches.

Morgan, D. W. and K. C. MacDonald

2011 Colonoware in Western Colonial Louisiana. In French Colonial Archaeology in the Southeast and Caribbean, edited by K. G. Kelly and M. D. Hardy, pp. 117-151. University Press of Florida, Gainesville.

Morrow, J. E.

2004 The Sacred Spiro Landscape, Cahokia Connections, and Flat Top Mounds. Central States Archaeological Journal 51:112-114.

2008 Piecing Together the Cherry Valley Phase. The Arkansas Archeologist $45: 1-5$.

Mulvihill, T.

2010 Radiocarbon Dating of the Pruitt Site (3LO769). Field Notes (Newsletter of the Arkansas Archeological Society) 352:7-9.

Murin, M.

2001 A Phase I/II Archeological Survey of the Proposed 50.3 Acre Port Site, Hanna, Red River Parish, Louisiana. Horizon Environmental Services, Inc., Austin.

Muto, G.

1978 The Habiukut of Eastern Oklahoma: Parris Mound Part 1, Phase 1, An Archaeological Report. Series in Anthropology No. 3. Oklahoma Historical Society, Oklahoma City.

Muto, G. R., M. S. Mayo, and K. Zahrai (editors)

1980 From Hunting and Gathering to Business and Banditry: Holocene Adaptations in Lee's Creek Valley, an Anthropological Assessment. Parris Mound Project Part 2, Phase 1. Series in Anthropology. Oklahoma Historical Society, Oklahoma City.

Napoleon, P. N.

1995 Analysis of Native-Made Ceramic Pipes. In The Deshazo Site, Nacogdoches County, Texas, Volume 2: Artifacts of Native Manufacture, 
edited by D. A. Story, pp. 157-171. Studies in Archeology 21. Texas Archeological Research Laboratory, The University of Texas at Austin.

Nash, L.

2017 The Cosmos in Clay: An analysis of Avery Engraved vessel motifs. Master's thesis, Cornell University, Ithaca, New York.

Nash, M. A. and E. K. Watkins

2009 Interim Report: National Register of Historic Places Eligibility Testing of Site 41SM404, Smith County, Texas. Document No. 090203. PBS\&J, Austin.

Nash, M. A., S. M. Kotter, and K. V. Reese-Taylor

1995 National Register Testing of Ten Sites in the Monticello B-2 Surface Mine, Titus County, Texas. Document No. 930529. Espey, Huston \& Associates, Inc., Plano.

Nash, M. A., L. W. Ellis, C. L. Wallace, and E. K. Watkins

2011 National Register of Historic Places Eligibility Testing of Site 41SM385 within TXDOT's Tyler District, Smith County, Texas. Document NO. 110016. PBS\&J, Austin.

Nash, M. A., T. K. Perttula, and L. W. Ellis

2012 National Register of Historic Places Eligibility Testing of Site 41SM404 within TxDOT's Tyler District, Smith County, Texas. Document No. 110055. Atkins, Austin.

Nassaney, M. S.

1991 Spatial-Temporal Dimensions of Social Integration During the Coles Creek Period in Central Arkansas. In Stability, Transformation, and Variation:

The Late Woodland Southeast, edited by M. S. Nassaney and C. R Cobb, pp. 177-220. Plenum Press, New York

1992 Communal Societies and the Emergence of Elites in the Prehistoric American Southeast. In Lords of the Southeast: Social Inequality and the Native Elites of Southeastern North America, edited by A. W. Barker and T. R. Pauketat, pp. 111-133. Archeological Papers No. 3. American Anthropological Association, Washington, D.C.

Neal, L.

1972 An Historical Cultural Assessment of the Proposed Clayton Lake, Pushmataha, Latimer, and Pittsburg Counties, Oklahoma. Oklahoma River Basin Survey, University of Oklahoma, Norman. 
1974 A Resurvey of the Prehistoric Resources of Tenkiller Ferry Lake. General Survey Report No. 13. Oklahoma River Basin Survey Project, University of Oklahoma, Norman.

1988 Archeological Survey of Clearcut Areas Along Little River, McCurtain and Pushmataha Counties, Oklahoma. Archeological Resource Survey Report No. 32. Oklahoma Archeological Survey, Norman.

1989 Investigations into the Prehistoric Resources of Southeastern Oklahoma. The Kiamichi Valley. Oklahoma Archeological Survey, Norman.

Neal, L. and M. Duncan

1990 Investigations into the Prehistoric Resources of Southeastern Oklahoma: The Kiamichi Valley II. Oklahoma Archeological Survey, Norman.

Neal, L. and M. A. Rees

1994 An Archaeological Survey of the Historic Native American Sites Associated with Military Posts of Oklahoma. Oklahoma Archeological Survey, Norman.

Neel, C., S. Gaither, K. Kahl, E. Giedraitis, and R. Burleson

2004 Cultural Resources Inventory of 4,000 Acres at Camp Gruber Army National Guard Training Center, Muskogee County, Oklahoma. Miscellaneous Reports, Camp Gruber Technical Series, Report of Investigations No. 2. LopezGarcia Group, Dallas.

Neel, C. D., K. Kahl, S. Gaither, R. S. Procter, and R. Burleson 2005 A Cultural Resources Investigation of the Proposed Bowie County Levee Realignment Project, Bowie County, Texas. Miscellaneous Reports, Report of Investigations No. 1. LopezGarcia Group, Dallas.

Neff, $\mathrm{H}$.

2002 Instrumental Neutron Activation Analysis. In Data Recovery Excavations at the McGuire's Garden Site (41FT425), Jewett Mine, Freestone County, Texas, by E. F. Gadus, J. K. McWilliams, and R. C. Fields, pp. 239-246. Report of Investigations No. 134. Prewitt and Associates, Inc., Austin.

2008 Review of Ceramic Compositional Studies from in and Around the Mississippi Valley. In Time's River: Archaeological Syntheses from the Lower Mississippi River Valley, edited by J. Rafferty and E. Peacock, pp. 223-242. University of Alabama Press, Tuscaloosa.

2009 Instrumental Neutron Activation Analysis Results from an Initial Study of Ear Spool Site Ceramic Sherds. In Data Recovery Investigations at the Ear Spool Site (41TT653), Titus County, Texas, by T. K. Perttula and D. L. Sherman, pp. C-1 to C-11. Document No. 070205. PBS\&J, Austin. 
Neff, H., J. W. Cogswell, and M. D. Glascock

1998 Compositional Analysis of Caddoan Ceramics from the Mockingbird Site (41TT550) in Northeast Texas. In Analysis of the Titus Phase Mortuary Assemblage at the Mockingbird Site or "Kahbakayammaahin" (41TT550), by T. K. Perttula, M. Tate, H. Neff, J. W. Cogswell, M. D. Glascock, E. Skokan, S. Mulholland, R. Rogers, and B. Nelson, pp. 255-272. Document No. 970849. Espey, Huston \& Associates, Inc., Austin.

1999 Compositional Analysis of Caddoan Ceramics from Northeast Texas. In The Hurricane Hill Site (41HP106): The Archaeology of a Late Archaic/Early Ceramic and Early-Middle Caddoan Settlement in Northeast Texas, edited by T. K. Perttula, pp. 303-319. Special Publication No. 4. Friends of Northeast Texas Archaeology, Pittsburg and Austin, Texas.

Neff, H. and M. D. Glascock

2000 Compositional Variation in Caddoan and Other Ceramics from Northeastern Texas: Update on Results of Instrumental Neutron Activation Analysis. University of Missouri Research Reactor, Columbia.

2005 Compositional Variation in Aboriginal Ceramics from Central Texas: Results of Instrumental Neutron Activation Analysis. In Analysis and Reporting for 41FY135, The Sandbur Site, Fayette County, Texas, by A. J. Kalter, R. M. Rogers, and M. N. Smith, pp. C-5 to C-35. Archeological Studies program Report No. 73. Texas Department of Transportation, Austin.

Nelson, B.

1993 The GG Site (41UR136): A Surface Evaluation in the Little Cypress Creek Drainage, Upshur County, Texas. The Cache: Collected Papers on Texas Archeology 1:73-76. Office of the State Archeologist, Texas Historical Commission, Austin.

Nelson, B. and T. K. Perttula

1993 Site 41UR136, a Titus Phase Site in the Little Cypress Creek Basin. Caddoan Archeology Newsletter 3(4):11-16.

1993 The Z. V. Davis-McPeek Site, an Early Caddoan Mound Site in the Little Cypress Creek Valley, Upshur County, Texas. Notes on Northeast Texas Archaeology 2:50-65.

1997 Documenting Looted Early, Middle, and Late Caddoan Cemetery Sites in Northeast Texas. The Steward, Collected Papers on Texas Archeology 4:3-14. Office of the State Archeologist, Texas Historical Commission, Austin. 
2003 Archeological Investigations of the Underwood Site (41CP230): A Titus Phase Settlement along Big Cypress Creek in Camp County, Texas. Journal of Northeast Texas Archaeology 17:1-61.

2003 Archeological Survey along the Lake Bob Sandlin Shoreline, Camp, Franklin, and Titus Counties, Texas. Report of Investigations No. 46. Archeological \& Environmental Consultants, LLC, Austin.

2006 Archaeological Investigations at the New Hope Site (41FK107) at Lake Bob Sandlin, Franklin County, Texas. Journal of Northeast Texas Archaeology 25:26-37.

2011 Archaeological Survey of 11 Acres for a Composting Area on the Anglin Farm in Hopkins County, Texas. Letter Report No. 30. Tejas Archaeology, Pittsburg.

2017 Archaeological Survey of the Proposed Waggoner Creek Crossing Project, Bowie County, Texas. Report of Investigations No. 4. Tejas Archaeology, Pittsburg.

2017 Archaeological Survey of 103 Acres at the Mineola Nature Preserve, Wood County, Texas. Report of Investigations No. 5. Tejas Archaeology, Pittsburg.

Nelson, B. and M. Turner

1997 Middle Caddoan Sites in the Cypress Creek Drainage Basin. Journal of Northeast Texas Archaeology 10:1-11.

Nelson, B., M. Crabb, and T. K. Perttula

2004 The Crabb Site (41TT650), a Prehistoric Caddo Site on Tankersley Creek, Titus County, Texas. Journal of Northeast Texas Archaeology 19:1-21.

Nelson, B., T. K. Perttula, and M. Turner

1994 Caddoan Archaeology in the Little Cypress Creek Valley: Recent Investigations at the Griffin Mound Site (41UR142), Upshur County, Texas. Caddoan Archeology Newsletter 5(3):6-17.

Nelson, B., M. Turner, and T. K. Perttula

1996 Archeological Investigations at the Griffin Mound Site: A Middle Caddoan Site in Upshur County, Texas. The Cache, Collected Papers on Texas Archeology 3:49-66. Office of the State Archeologist, Texas Historical Commission, Austin.

Neuman, R. W.

1970 Archaeological and Historical Assessment of the Red River Basin in Louisiana. In Archeological and Historical Resources of the Red River 
Basin: Louisiana, Texas, Oklahoma, Arkansas, edited by H. A. Davis, pp. 3-25. Research Series No. 1. Arkansas Archeological Survey, Fayetteville.

1974 Caddoan Indians II. Garland Publishing Inc., New York.

1983 The Buffalo in Southeastern United States Post-Pleistocene Prehistory. In Southeastern Natives and Their Pasts, edited by D. G. Wyckoff and J. L. Hofman, pp. 261-280. Studies in Oklahoma's Past No. 11. Oklahoma Archeological Survey, Norman.

1984 An Introduction to Louisiana Archaeology. Louisiana State University Press, Baton Rouge.

Neuman, R. W. and N. W. Hawkins

1993 Louisiana Prehistory. 2nd Edition. Anthropological Study Series No. 6. Department of Culture, Recreation and Tourism, Louisiana Archaeological Survey, Baton Rouge.

Neumann, G. K.

1942 Types of Artificial Cranial Deformation in the Eastern United States. American Antiquity 7:306-310.

Newberry, N., D. Gray, P. Mansker, and B. Wade

1986 An Unusual "Cache" from the Fourche Maline Valley. Bulletin of the Oklahoma Anthropological Society 35:41-50.

New World Research, Inc.

1981 A Cultural Resources Survey of the Proposed TransAnadarko Pipeline System, Texas, Oklahoma, Arkansas, Louisiana. New World Research, Inc., Pollock, Louisiana.

Newell, H. P.

1940 Alto Mound. Texas Archaeological News, An Occasional Report issued by The Council of Texas Archaeologists 2:22-23.

Newell, H. P and A. D. Krieger

1949 The George C. Davis Site, Cherokee County, Texas. Memoir No. 5. Society for American Archaeology, Menasha, Wisconsin.

2000 The George C. Davis Site, Cherokee County, Texas. 2nd Edition. Society for American Archaeology, Washington, D.C.

Newkirk, J. A.

1981 A Cultural Resources Survey of the Red River Waterway from Shreveport, Louisiana to the Mississippi River. Commonwealth Associates, Inc., Jackson, Michigan. 
Newkumet, P. J.

1940 Excavation of "Black Mound" Reveals Ornate "Hair Pins." The Oklahoma Prehistorian 3(2):8-9.

1940 Preliminary Report on Excavations of the Williams Mound, LeFlore County, Oklahoma. The Oklahoma Prehistorian 3(2):2-6.

Nichols, P., M. Parsons, M. D. Freeman, L. Banks, D. Shanabrook, and B. Rader 1997 Test Excavations at Proposed Lake Gilmer, Upshur County, Texas. Horizon Environmental Services, Inc., Austin.

Nickels, D. L., L. C. Nordt, T. K. Perttula, C. B. Bousman, and K. Miller 1999 Archaeological Survey of the Southwest Block and Selected Roads and Firebreaks at Camp Maxey, Lamar County, Texas. Archaeological Survey Report No. 290. Center for Archaeological Research, The University of Texas at San Antonio.

Norment, A. R., K. W. Kibler, and A. E. Dase 2012 Archeological Site Assessments and Survey at Aquilla Lake, Hill County, Texas. Technical Reports No. 87. Prewitt and Associates, Inc., Austin.

North American Consultants, Inc.

1985 Summary Report- Backhoe Trenching at 41HS282, South Hallsville Project, Harrison County, Texas. North American Consultants, Inc., Dallas.

Northern, M. J. and B. D. Skiles

1981 Cultural Resources Overview of the Proposed Black Cypress and Marshall Reservoirs. Cultural Resources Report 81-11. Environmental Consultants, Inc., Dallas.

Northern, M., B. Skiles, and S. A. Skinner

1981 Cultural Resources Overview of Two East Texas Pipeline Routes. Investigative Report No. 81-8. Environmental Consultants, Inc., Dallas.

Northrip, J. D. and W. J. Bennett, Jr.

2003 Cultural Resources Survey, Weiser-Brown Operating Co., "ES 2495 No. 33" Johnson County, Arkansas. Report No. 311. Archeological Assessments, Inc., Nashville, Arkansas.

2003 Cultural Resources Survey Bowman \& Cains, LLC "Kirkpatrick No. 5" Franklin County, Arkansas. Report No. 305. Archeological Assessments, Inc., Nashville, Arkansas. 
2003 Cultural Resources Survey Floyd E. Sagely Properties, Ltd. "H. H. Carruth No. 1-15". Report No. 306. Archeological Assessments Inc., Nashville, Arkansas.

2003 Cultural Resources Survey for the Wooten 1-14 Well Connect Pipeline Sebastian County, Arkansas. Report No. 310. Archeological Assessments, Nashville, Arkansas.

2003 Cultural Resources Survey, TeleCom Acquision One Site: "Buckner AR" Columbia County, Arkansas. Report No. 309. Archeological Assessments, Inc., Nashville, Arkansas.

2003 Cultural Resources Survey, Thomas C. Mueller "Don Oliver No. 5-3", Franklin County. Report No. 307. Archeological Assessments, Inc., Nashville, Arkansas

2003 Cultural Resources Survey XTO Energy, Inc. "Hunt Hembree No. 6-11" and "Hunt Hembree No. 7-11"a. Report No. 302. Archeological Assessments, Inc., Nashville, Arkansas.

2004 Cultural Resources Survey CDX GAS, LLC Proposed Gathering Line Ouachita National Forest Lands Sebastian County, Arkansas. Report No. 316. Archeological Assessments, Inc., Nashville, Arkansas.

Odell, G. H.

2002 La Harpe's Post: A Tale of French-Wichita Contact on the Eastern Plains. University of Alabama Press, Tuscaloosa.

2005 The Protohistoric Period in Eastern Oklahoma: Evidence from the Lasley Vore Site. Bulletin of the Oklahoma Anthropological Society 47:83-117.

O’Kelly, L., M. B. Cliff, S. Fischbeck, B. M. Harris, S. Loftus, R. J. Norris, R. Rogers, J. Shipp, and C. L. Wallace

2009 Intensive Archeological Survey for the Texas Department of Transportation Farm to Market Road 1000, Mount Pleasant, Titus County, Texas. PBS\&J, Inc., Dallas.

Orchard, C. D. and T. N. Campbell

1960 Southwestern Pottery from Sites in the Vicinity of San Antonio, Texas. Texas Archeology 4(2):7-8.

Orr, K. G.

1939 Indian Villages Surrounding the Spiro Mounds, LeFlore County, Oklahoma. Society for American Archaeology Notebook 1:76-77. 
1939 Field Report of the Excavation of Indian Villages in the Vicinity of the Spiro Mounds, LeFlore County, Oklahoma. The Oklahoma Prehistorian 2(2):815.

1941 The Eufala Mound: Contributions to the Spiro Focus. The Oklahoma Prehistorian 4(1):2-15.

1942 The Eufala Mound Oklahoma: Contribution to the Spiro Focus. Master's thesis, Department of Anthropology, University of Chicago, Chicago.

1946 The Archaeological Situation at Spiro, Oklahoma: A Preliminary Report. American Antiquity 11:228-256.

1950 Field Notes on Laboratory Analysis of Sites in the Spiro Area, LeFlore County, Oklahoma. Microfilm Publications, University of Chicago, Chicago.

1950 Summary Studies of Sites in the Spiro Area, LeFlore County, Oklahoma. Microfilm Publications, University of Chicago, Chicago.

1952 Survey of Caddoan Area Archeology. In Archeology of the Eastern United States, edited by J. B. Griffin, pp. 239-255. University of Chicago Press, Chicago.

Osburn, T., J. Bruseth, and W. Pierson

2008 Magnetometer Investigations at the George C. Davis Site, a Prehistoric Caddo Village. Bulletin of the Texas Archeological Society 79:191-200.

Ouachita Chapter, Arkansas Archeological Society

2014 What's for Supper? Native American Foods in the Ouachita Mountains. Privately printed.

Owens, J. D.

2015 Cultural Resources Baseline Studies: Lake Columbia Water Supply Project, Cherokee and Smith Counties, Texas. Horizon Environmental Services, Inc., Austin.

Owens, J. D. and S. M. Hunt

1999 Archaeological Test Excavations at Five Prehistoric Sites at the Proposed Malden Lake Park Expansion, Wright Patman Lake, Bowie County, Texas. Miscellaneous Reports of Investigations No. 189. Geo-Marine, Inc., Plano.

Owens, J. D., F. B. Largent, Jr., and M. J. Guccione

2000 Relocation and Reinvestigation of 45 Archeological Sites at Wister Lake, LeFlore County, Oklahoma. Miscellaneous Report of Investigations Number 168. Geo-Marine, Inc., Plano. 
Pangborn, R. E.

1966 Eureka Mound, 23Da-250, Illustrating Caddoan Contacts in the Stockton Reservoir Area, Southwestern Missouri. Plains Anthropologist 11(32):166167.

Parrish, J. L., D. Bruner, D. Greer, A. Lee, A. Montana, E. Parrish, R. L. Smith, D. Womble, and J.-K. Yakubik

2011 Phase II Archeological Investigations at Red River Army Depot and Lone Star Army Ammunition Plant, Bowie County, Texas. Earth Search, Inc., New Orleans.

Parsons, A. R.

1954 Archeological Notes (Mounds in Oklahoma). Oklahoma Anthropological Society Newsletter 3(4):4-5.

Parsons, M. L.

1998 41UR133: A Late Caddo Hamlet at Lake Gilmer. Cultural Resource Management News \& Views 10(1):16-19. Division of Antiquities Protection, Texas Historical Commission, Austin.

2015 Archeological Investigations at Lake Gilmer, Upshur County, Texas Mitigation Phase. Archeology Reports Series, No. 6. Texas Historical Commission, Austin.

Parsons, M. L., J. Bruseth, J. Bagur, and C. McCrocklin 2002 Finding Sha'chahdinnih (Timber Hill): The Last Village of the Kadohadacho in the Caddo Homeland. Plains Anthropologist 47(182):231249.

Parsons, M. L., J. E. Bruseth, J. Bagur, S. E. Goldborer, and C. McCrocklin 2002 Finding Sha'chahdinnih (Timber Hill): The Last Village of the Kadohadacho in the Caddo Homeland. Archeological Reports Series No. 3. Texas Historical Commission, Austin.

Parsons, M. L., J. E. Bruseth, H. Thomason, and B. Haumpo 1998 Excavations at the Rookery Ridge Site, Lake Gilmer, Northeast Texas. Caddoan Archeology 8(4):27.

Parsons, M., M. D. Freeman, D. Shanabrook, and B. Keeley 1992 Cultural Resources of the Proposed Lake Gilmer Project, Upshur County, Texas. Horizon Environmental Services, Inc., Austin.

Patterson, L. W.

1992 The Tucker Collection: Prehistoric Site in Nacogdoches, Texas. Journal of the Houton Archeological Society 103:16-23. 
Pauketat, T. R.

2015 The Caddo Conundrum. In Medieval Mississippians: The Cahokian World, edited by T. R. Pauketat and S. M. Alt, p. 14. School for Advanced Research Press, Santa Fe.

Pearce, J. E.

1919 Indian Mounds and other Relics of Indian Life in Texas. American Anthropologist 21(3):223-234.

1920 Explorations near Frankston, Texas. MS on file, Texas Archeological Research Laboratory, The University of Texas at Austin.

1920 Early Work in East Texas. MS on file, Texas Archeological Research Laboratory, The University of Texas at Austin.

1932 The Archaeology of East Texas. American Anthropologist 14:670-687.

1932 The Significance of the East Texas Archaeological Field. In Conference on Southern Pre-History, pp. 53-58. National Research Council, Washington, D.C.

1932 The Present Status of Texas Archeology. Bulletin of the Texas Archeological and Paleontological Society 4:44-54.

Pearce, J. E. and A. T. Jackson

1931 Notes on Field Work, H. R. Taylor Farm, Harrison County, Texas, June 28, 1931 to July 22, 1931. MS on file, Texas Archeological Research Laboratory, The University of Texas at Austin.

1931 Notes on Field Work, T. M. Sanders farm, Lamar County, Texas, July 23 to August 28, 1931. MS on file, Texas Archeological Research Laboratory, The University of Texas at Austin.

1931 Field Notes: Excavation on the H. E. Womack Farm, Lamar County, Texas, August 29, 1931 to September 4, 1931. MS on file, Texas Archeological Research Laboratory, The University of Texas at Austin.

Pearce, J. E. and A. M. Woolsey

1935 Notes on Field Work, Jasper Tucker Farm, Mrs. Joe Watkins Owner, 9 Miles southwest of Frankston, Anderson County, Texas, November 20 to November 22, 1935. MS on file, Texas Archeological Research Laboratory, The University of Texas at Austin.

Pearson, C. E. 
1982 Geomorphology and Prehistoric Patterns in the Great Bend Region. In Contributions to the Archeology of the Great Bend Region, edited by F. F. Schambach and F. Rackerby, pp. 12-29. Research Series No. 22. Arkansas Archeological Survey, Fayetteville.

1986 Dating the Course of the Lower Red River in Louisiana: the Archaeological Evidence. Geoarchaeology 1:39-42.

Pearson, C. E. and G. J. DuCote

1979 Cultural Resources Survey of Four Proposed Construction Projects Along the Red River in Southwestern Arkansas. Coastal Environments, Inc., Baton Rouge.

Pearson, C. E. and D. G. Hunter

1993 Geoarchaeology of the Red River Valley. In Quaternary Geology and Geoarchaeology of the Lower Red River Valley, edited by W. Autin and J. Snead, pp. 25-43. Friends of the Pleistocene, South Central Cell, 11th Annual Field Conference Guidebook.

Pearson, F. J., Jr., E. Mott Davis, Murray A. Tamers, and Robert W. Johnston 1965 University of Texas Radiocarbon Dates III. Radiocarbon 7;296-314.

Pearson, F. J., Jr., E. Mott Davis, and Murray A. Tamers 1966 University of Texas Radiocarbon Dates IV. Radiocarbon 8:453-466.

Pemberton, F. H., R. Norris, and M. B. Cliff 2009 Intensive Archeological Survey for the North East Texas Regional Mobility Authority Proposed Loop 49, Segment 3A Between State Highway 31 and State Highway 155 Tyler, Smith County, Texas. Document No. 080104. PBS\&J, Dallas.

Penman, J. T., J. Freshwater, and S. M. Houghton

2004 Phase II Test Excavations at Five Historic Sites (3MI355, 3MI359, 3MI378, 3 MI396, and 3MI410) on U. S. Highway 71, Texarkana to Louisiana State Line, Miller County, Arkansas. Project 20117. Burns \& McDonnell Engineering Co., Kansas City.

Penman, J. T., S. M. Houghton, C. McCrocklin, and V. S. Jones 2004 Mitigation of Two Historic Sites (3MI409 and 3MI422) on U. S. Highway 71, Texarkana to Louisiana State Line, Miller County, Arkansas. Project 20117. Burns \& McDonnell Engineering Co., Kansas City.

Penman, J. T., R. D. Mandel, T. K. Perttula, and D. R. Dickson 2004 Final Report on the Mitigation of the Johnson Farm \#5 Site (3Ml128) on U. S. Highway 71, Texarkana to Louisiana State Line, Miller County, 
Arkansas. Project 20117. Burns \& McDonnell Engineering Co., Kansas City.

Perino, G.

1967 Report on Field Burials 24, 26, and 28 at the Haley Place, Miller County, Arkansas. Oklahoma Anthropological Society Newsletter 15(5):1-8.

1969 Shells and Their Use by the Indians. Central States Archaeological Journal 16:128-133.

1976 A Reconnaissance and Assessment of the Archeological Resources of DeQueen Lake and Gillham Lake in Southwestern Arkansas. Museum of the Red River, Idabel.

1976 Discoveries in McCurtain County. Oklahoma Anthropological Society Newsletter 24(9):7-11.

1978 Four McCurtain Focus Caddoan Vessels. Central States Archaeological Journal 25:74-76.

1979 The Identification of Three Early Historic Caddoan Vessels. Central States Archaeological Journal 26:24-26.

1981 Archeological Investigations at the Roden Site (MC-215), McCurtain County, Oklahoma. Potsherd Press No. 1. Museum of the Red River, Idabel.

1983 Archaeological Research at the Bob Williams Site (41RR16), Red River County, Texas. Museum of the Red River, Idabel.

1994 Archaeological Research at the Rowland Clark Site (41RR77), Red River County, Texas. Journal of Northeast Texas Archaeology 4:3-42.

1995 The Dan Holdeman Site (41RR11), Red River County, Texas. Journal of Northeast Texas Archaeology 6:3-65.

Perino, G. and W. J. Bennett, Jr.

1978 Archaeological Investigations at the Mahaffey Site, CH-1, Hugo Reservoir, Choctaw County, Oklahoma. Museum of the Red River, Idabel.

Perino, G. and F. Soday

1977 The 49th and Cameron Streets Site, Tulsa, Oklahoma. Central States Archaeological Journal 24(3):106-115.

Perino, G., J. Caffey, M. E. Good, M. Getys, and P. W. Parmalee 
1980 The Eufala Lake Project, A Cultural Resource Survey and Assessment. Museum of the Red River, Idabel.

Perkins, J. L.

1955 The Big Sandy Site, W-2. The Record 13(3):20-24. Dallas Archeological Society, Dallas.

1955 Burial 16 at the Sam Kaufman Site 19B3-2. The Record 14(1):2-6. Dallas Archeological Society, Dallas.

Perrault, S. L., N. C. Kaplan, and A. Saatkamp

2008 National Register of Historic Places Eligibility Testing of Ten Archaeological Sites on the Red River below Denison Dam, Item 9-A, Levee Rehabilitation, Lafayette County, Arkansas. Panamerican Consultants, Inc., Memphis.

Perttula, T. K.

1980 Caddoan Prehistory: Some Relationships to Lower Mississippi Valley Prehistory. Southeastern Archaeological Conference Bulletin 21:119-123.

1980 Comments on G. Perino's “The Identification of Three Early Historic Caddoan Vessels." Central States Archaeological Journa1 27:23-24.

1982 Caddoan Archaeology and the Consideration of Regional Research Problems. Oklahoma Anthropological Society Newsletter 30(1):6-8.

1983 The Loftin Site and Phase in Western Ozark Prehistory. Missouri Archaeologist 44:40-62.

1984 Patterns of Prehistoric Lithic Raw Material Utilization in the Caddoan Area: Western Gulf Coastal Plain. In Prehistoric Chert Exploitation: Studies from the Mid-Continent, edited by B. M. Butler and E. E. May, pp.129-148. Occasional Paper 2. Center for Archaeological Investigations, Southern Illinois University, Carbondale.

1984 A Note on "The Buffalo in Southeastern United States Post-Pleistocene Prehistory." Oklahoma Anthropological Society Newsletter 32(1):4-6.

1988 Cultural Resources Survey at Cooper Lake, Delta and Hopkins Counties, Texas. Institute of Applied Sciences, North Texas State University, Denton.

1989 A Study of Mound Sites in the Sabine River Basin, Northeast Texas and Northwest Louisiana. Institute of Applied Sciences, University of North Texas, Denton. 
1989 Contact and Interaction between Caddoan and European Peoples. The Historic Archaeological and Ethnohistorical Records. Ph.D. dissertation, Department of Anthropology, University of Washington, Seattle.

1989 The Looting and Vandalism of Archaeological Sites in East Texas: A Status Report. Office of the State Archeologist and Archeological Planning and Review, Texas Historical Commission, Austin.

1989 The Late Prehistoric Period in the Western Ozarks of Southwest Missouri. In Contributions to Spiro Archaeology: Mound Excavations and Regional Perspectives, edited by J. D. Rogers, D. G. Wyckoff, and D. A. Peterson, pp. 117-127. Studies in Oklahoma's Past No. 16. Oklahoma Archeological Survey, Norman.

1990 The Development of Agricultural Subsistence, Regional and Diachronic Variability in Caddoan Subsistence, and Implications for the Caddoan Archaeological Record. Department of Archeological Planning and Review, Texas Historical Commission, Austin.

1991 European Contact and its Effects on Aboriginal Caddoan Populations between A.D. 1520 and A.D. 1680. In Columbian Consequences, Vol. 3, The Spanish Borderlands in Pan-American Perspective, edited by D. H. Thomas, pp. 501-518. Smithsonian Institution Press, Washington, D.C.

1992 "The Caddo Nation": Archaeological and Ethnohistoric Perspectives. University of Texas Press, Austin.

1992 The Looting and Vandalism of Archaeological Sites in East Texas. American Society for Conservation Archaeology Report 18(2):3-13.

1993 The Development of Agriculture in Northeast Texas before A.D. 1600. In Archeology in the Eastern Planning Region, Texas: A Planning Document, edited by N. A. Kenmotsu and T. K. Perttula, pp. 121-146. Cultural Resource Management Report 3. Department of Antiquities Protection, Texas Historical Commission, Austin.

1993 The Effects of European Contact on Native and Immigrant Indians in Northeast Texas. In Archeology in the Eastern Planning Region, Texas: A Planning Document, edited by N. A. Kenmotsu and T. K. Perttula, pp. 147187. Cultural Resource Management Report 3. Department of Antiquities Protection, Texas Historical Commission, Austin.

1993 Kee-Oh-Na-Wah'-Wah: The Effects of European Contact on the Caddoan Indians of Texas, Louisiana, Arkansas and Oklahoma. In Ethnohistory and Archaeology: Approaches to Postcontact Change in the Americas, edited by J. D. Rogers and S. M. Wilson, pp. 89-109. Plenum Press, New York. 
1993 The Long-Term Consequences and Effects of the de Soto Entrada on Aboriginal Caddoan Populations. In The Expedition of Hernando de Soto West of the Mississippi, 1541-1543: Proceedings of the DeSoto Symposia 1988 and 1990, edited by G. A. Young and M. P. Hoffman, pp. 237-254. University of Arkansas Press, Fayetteville.

1994 Caddoan Mound Sites in the Sabine River Basin of Northeast Texas. Caddoan Archeology Newsletter 4(4):4-19.

1995 The Archeology of the Pineywoods and Post Oak Savanna of Northeast Texas. Bulletin of the Texas Archeological Society 66:331-359.

1995 Collected Papers on Caddoan Archaeology in the Upper Sabine River Basin, Northeastern Texas. Special Publication No. 1. Friends of Northeast Texas Archaeology, Pittsburg and Austin.

1995 A Reconsideration of the Chronological and Cultural Placement of the Mortuary Remains and Grave Goods from the Dan Holdeman Site. Journal of Northeast Texas Archaeology 6:67-87.

1995 Early Ceramic Settlement in Northeast Texas: Archeological Investigations of the Hurricane Hill Site (41 HP106), Cooper Lake. In Advances in Texas Archeology: Contributions from Cultural Resource Management, edited by J. E. Bruseth and T. K. Perttula, pp. 131-154. Cultural Resource Management Report 5. Department of Antiquities Protection, Texas Historical Commission, Austin.

1996 Caddoan Area Archaeology since 1990. Journal of Archaeological Research 4(4):295-348

1996 Taddlock Site. In The New Handbook of Texas, Vol. 6, edited by R. Tyler, p. 191. Texas State Historical Association, Austin.

1997 Sabine River and Middle Red River Ceramics: Musings on the Ceramic Data used in Schambach's "Continuing the Discussion of the Spiroans and Their Entrepots." Caddoan Archeology 8(3):9-18.

1997 Middle Caddoan Period Archaeology in the Upper Sulphur River Basin. Journal of Northeast Texas Archaeology 10:41-46.

1997 The Archaeology of the Middle Caddoan Period in the Middle Red River Valley of Northeast Texas. Journal of Northeast Texas Archaeology 10:4751. 
1998 Late Caddoan Societies in the Northeast Texas Pineywoods. In The Native History of the Caddo: Their Place in Southeastern Archeology and Ethnohistory, edited by T. K. Perttula and J. E. Bruseth, pp. 69-90. Studies in Archeology 30. Texas Archeological Research Laboratory The University of Texas at Austin.

1998 Caddo Ceramics from the Middle Caddoan Period Knight's Bluff Site (41CS14), Cass County, Texas. Caddoan Archeology 8(4):11-19.

1998 A Compendium of Radiocarbon and Oxidizable Carbon Ratio Dates from Archaeological Sites in East Texas, with a Discussion of the Age and Dating of Select Components and Phases. Radiocarbon 39(3):305-342.

1998 Radiocarbon and Oxidizable Carbon Ratio Dates from Archaeological Sites in East Texas, Part II. Journal of Northeast Texas Archaeology 11:66-90.

1998 Decorated Caddoan Ceramics from Two Sites on the Elm Fork of the Trinity River, Dallas County, Texas. Journal of Northeast Texas Archaeology 11:49-54.

1999 (Editor) The Hurricane Hill Site (41HP106): The Archaeology of a Late Archaic/Early Ceramic and Early-Middle Caddoan Settlement in Northeast Texas. 2 Vols. Special Publication No. 4. Friends of Northeast Texas Archaeology, Pittsburg and Austin.

1999 Regional Comparisons in Paste Composition from Petrographic Analyses. In The Hurricane Hill Site (41HP106): The Archaeology of a Late Archaic/Early Ceramic and Early-Middle Caddoan Settlement in Northeast Texas, edited by T. K. Perttula, pp. 291-297. 2 Vols. Special Publication No. 4. Friends of Northeast Texas Archaeology, Pittsburg and Austin.

1999 Current Archeological Investigations at the Pilgrim's Pride Site (41CP304) in Camp County, Texas. Caddoan Archeology 10(2):7-18.

2000 The Caddoan Ceramics from the Gray's Pasture Site (41HS524), Harrison County, Texas. Journal of Northeast Texas Archaeology 13:1-38.

2000 Caddo Ceramics from 41CV41A at Fort Hood, Coryell County, Texas. Journal of Northeast Texas Archaeology 12:27-30.

2000 Functional and Stylistic Analyses of Ceramic Vessels from Mortuary Features at a 15th and 16th Century Caddo Site in Northeast Texas. Midcontinental Journal of Archaeology 25(1):101-151. 
2000 (Editor) An Archeological Survey of the Proposed Lake Naconiche, Nacogdoches County, Texas. Report of Investigations No. 35. Archeological and Environmental Consultants, LLC, Austin.

2000 Results of the Instrumental Neutron Activation Analysis of Caddo Vessel Sherds from the Helm Site (3HS449). In Data Recovery at the Helm Site, 3HS449, Hot Spring County, Arkansas, by R. H. Lafferty, A. M. Early, M. C. Sierzchula, M. C. Hill, G. S. Powell, N. H. Lopinot, L. S. Cummings, S. L. Scott, S. K. Nash, and T. K. Perttula, pp. G-1 to G-5. MCRA Report 2000-1. Mid-Continental Research Associates, Inc., Lowell, Arkansas.

2001 "The Great Kingdom of the Tejas": The Life and Times of Caddo Peoples in Texas between ca. 1530-1859. Bulletin of the Texas Archeological Society 72:73-89.

2001 Three Mid-1800s Caddo Vessels from the Brazos Reserve. Journal of Northeast Texas Archaeology 14:31-36.

2001 Texas in the Year 1000: What It Was Like Then in East Texas. Journal of Northeast Texas Archaeology 15:29-36.

2001 Prehistoric Ceramic Sherds from 41MM341. In National Register Eligibility Testing of 41MM340 and 41MM341, along Little River, Milam County, Texas, by R. B. Mahoney and S. A. Tomka, pp. 124-125. Archaeological Survey Report No. 303, Center for Archaeological Research, The University of Texas at San Antonio, and Report No. 30, Archeological Studies program, Environmental Affairs Division, Texas Department of Transportation, Austin.

2002 Archaeological Evidence for the Long-Distance Exchange of Caddo Indian Ceramics in the Southern Plains, Midwest, and Southeastern United States. In Geochemical Evidence for Long-Distance Exchange, edited by M. D. Glascock, pp. 89-107. Bergin and Garvey, Westport, Connecticut.

2002 (Editor) Archeological Investigations at the Proposed Lake Naconiche, Nacogdoches County, Texas. 2 Vols. Report of Investigations No. 42. Archeological and Environmental Consultants, LLC, Austin.

2002 Caddoan Area Protohistory and Archaeology. In Between Contacts and Colonies: Archaeological Perspectives on the Protohistoric Southeast, edited by C. B. Wesson and M. A. Rees, pp. 49-66. University of Alabama Press, Tuscaloosa.

2002 Social Changes among the Caddo Indians in the Sixteenth and Seventeenth Centuries. In The Transformation of the Southeastern 
Indians, 1540-1760, edited by R. Ethridge and C. Hudson, pp. 249-269. University Press of Mississippi, Jackson.

2002 Caddo Ceramics from 41HS835, Harrison County, Texas. In A Phase I Cultural Resources Survey of the Blocker-Crossroads WSC Water Line Project in Central Harrison County, Texas, by W. E. Moore, pp. All 1-13. Contract Report No. 103. Brazos Valley Research Associates, Bryan.

2004 The Prehistoric and Caddoan Archeology of the Northeast Texas Pineywoods. In The Prehistory of Texas, edited by T. K. Perttula, pp. 370407. Texas A\&M University Press, College Station.

2005 (Editor) Archeological Investigations at the Pilgrim's Pride Site (41CP304), a Titus Phase Community in the Big Cypress Creek Basin, Camp County, Texas. 2 Vols. Report of Investigations No. 30. Archeological \& Environmental Consultants, LLC, Austin.

2005 1938-1939 WPA Excavations at the Hatchel Site (41BW3) on the Red River in Bowie County, Texas. Southeastern Archaeology 24(2):180-198.

2005 The M. W. Burks Site (41WD52), A Late Caddo Hamlet in Wood County, Texas. Journal of Northeast Texas Archaeology 23:1-27.

2005 The Cranfill Site (41BW171), a Prehistoric Caddo Site in the Red River Valley, Bowie County, Texas. Journal of Northeast Texas Archaeology 22:1-37.

2005 The Indian Springs \#2 Site (41BW512): A Late $18^{\text {th }}$ Century Kadohadacho Settlement in Northeastern Texas. Journal of Northeast Texas Archaeology 22:39-52.

2005 Views of the Hatchel Site (41BW3) during the 1938-1939 WPA Excavations. Journal of Northeast Texas Archaeology 22:65-76.

2006 A Study of the Buddy Jones Collection from Northeast Texas Caddo Sites. Special Publication No. 6. Friends of Northeast Texas Archaeology, Pittsburg and Austin.

2006 The Structure and Growth of a Titus Phase Community Cemetery in Titus County, Texas. Journal of Northeast Texas Archaeology 25:1-18.

2006 Winston's Mound and Shawnee Town: Mound Explorations by the Bureau of American Ethnology in Texas, 1882-1884. Bulletin of the Texas Archeological Society 76:183-187. 
2006 The Ceramic and Lithic Assemblage from a Late Prehistoric Site (41RT510) in the Post Oak Savanna, Robertson County, Texas. La Tierra 32(2):21-24.

2007 The History of Archaeological Investigations at the Jamestown Mound Site (41SM54), An Archaeological Conservancy Preserve in Smith County, Texas. Caddo Archeology Journal 16:45-56.

2007 Points of Discusson and Directions for Research on Caddo Historic Archaeology. Journal of Northeast Texas Archaeology 26:8-10.

2007 One Attempt at Defining Allen Phase Ceramic Subclusters. Journal of Northeast Texas Archaeology 26:77-81.

2007 Kinsloe Focus Artifact Assemblages and Nadaco Caddo. Journal of Northeast Texas Archaeology 26:116-119.

2007 Inverted Rim Engraved Vessels in Protohistoric and Early Historic Caddo Sites in Parts of Northeast Texas. Journal of Northeast Texas Archaeology 26:136-144.

2007 Seriation Proposed by Kleinschmidt (1982:Table 19) of Allen Phase and Frankston Phase Sites in the Upper Neches River Basin. Journal of Northeast Texas Archaeology 26:150-153.

2007 Upper Neches River Basin Caddo Ceramics, an Attempt at an Updated Seriation and a Context for Understanding Frankston to Allen Phase Ceramic Stylistic and Technological Change. Journal of Northeast Texas Archaeology 26:154-158.

2007 The C. C. Jones Collections from a Protohistoric Caddo Site in the Vicinity of Shreveport, LA. Newsletter of the Louisiana Archaeological Society 35(1):5-7.

2007 San Pedro Creek/Mission Tejas Sherd Collections at Mission Tejas State Park, Houston County, Texas. Letter Report No. 188. Archeological \& Environmental Consultants, LLC, Austin.

2008 Caddo Agriculture on the Western Frontier of the Eastern Woodlands. Plains Anthropologist 53(205):79-105.

2008 The Archeology of the Roitsch Site (41RR16), an Early to Historic Caddo Period Village on the Red River in Northeast Texas. In Collected Papers from Past Texas Archeological Society Summer Field Schools, edited by T. K. Perttula, pp. 313-628. Special Publication No. 5. Texas Archeological Society, San Antonio. 
2008 Archeological Survey of the Roitsch Farm and Adjoining Lands, 1991 and 1992 Texas Archeological Society Field School, Red River County, Texas. In Collected Papers from Past Texas Archeological Society Summer Field Schools, edited by T. K. Perttula, pp. 173-312. Special Publication No. 5. Texas Archeological Society, San Antonio.

2008 (Editor) Lake Naconiche Archeology, Nacogdoches County, Texas: Results of the Data Recovery Excavations at Five Prehistoric Archeological Sites. 2 Vols. Report of Investigations No. 60. Archeological \& Environmental Consultants, LLC, Austin.

2008 Caddo Ceramics from the D'Ortolan Site (41NA299). Journal of Northeast Texas Archaeology 28:21-23.

2008 Historic Caddo Archaeology on the Red and Lower Sulphur River Areas of Northeast Texas. Journal of Northeast Texas Archaeology 28:25-34.

2008 Analysis of the Historic Caddo Ceramics from 41NA223 in Downtown Nacogdoches, Nacogdoches County, Texas. Journal of Northeast Texas Archaeology 28:35-50.

2008 Trends and Varieties in Late Caddo and Historic Caddo Fine Ware Pottery Types in the Upper Neches River Basin. Journal of Northeast Texas Archaeology 28:51-55.

2008 Caddo Ceramics from Two Sites in the Post Oak Savanna, Leon County, Texas. La Tierra 35: 87-89.

2009 A Radiocarbon Date from a Cedar Pole in a Special Caddo Burial Feature at the Shelby Mound site (41CP71). Texas Archeology 53(1):20-21.

2009 Extended Entranceway Structures in the Caddo Archaeological Area. Southeastern Archaeology 28(1):27-42.

2009 The Caddo Ceramics from the Dragover Site (3MN298) on the Ouachita River on Ouachita National Forest Land in Montgomery County, Arkansas. The Arkansas Archeologist 48:1-14.

2009 Caddo Ceramics from two Sites in the Post Oak Savanna, Leon County, Texas. La Tierra 35(4):82-84.

2009 Analysis of the Caddo Archeological Materials from the 1985 Texas Archeological Society Field School at the Washington Square Mound Site, Nacogdoches County, Texas. Bulletin of the Texas Archeological Society 80:145-193. 
2009 Frankston Phase Ceramics from the Alcoa \# 1 (41AN87) Site, Mound Prairie Creek, Anderson County, Texas. Journal of Northeast Texas Archaeology 29:23-44.

2009 The Ceramics from a Late Caddo Site on Mud Creek in Cherokee County, Texas. Journal of Northeast Texas Archaeology 29:45-52.

2009 Late Caddo Ceramics from 41HE337 in Henderson County, Texas. Journal of Northeast Texas Archaeology 29:53-57.

2009 Ceramic Vessel Sherds from the Kah-Hah-Ko-Wha Site (41CE354), an Allen Phase Component in Northwestern Cherokee County, Texas. Journal of Northeast Texas Archaeology 29:59-79.

2009 The Archaeology of the $16^{\text {th }}$ and $17^{\text {th }}$ Century Caddo in the Post Oak Savannah of Northeast Texas: The Tuinier Farm (41HP237), R. A. Watkins (41HP238), and Anglin (41HP240) Sites in the Stouts Creek Basin, Hopkins County, Texas. Journal of Northeast Texas Archaeology 30:1-132.

2009 Caddo Sherds from the Hudnall-Pirtle Site (41RK4) in the Buddy Jones Collection at the Gregg County Historical Museum. Journal of Northeast Texas Archaeology 31:37-40.

2009 A $19^{\text {th }}$ Century Caddo Component at the Gatlin Site (41RK1) in the Angelina River Basin of East Texas. Journal of Northeast Texas Archaeology 31:41-44.

2009 Towards the Concerted Study of Caddo Origins. Journal of Northeast Texas Archaeology 31:49-50.

2009 Lake Naconiche Archaeology and Caddo Origins Issues. Journal of Northeast Texas Archaeology 31:61-85.

2009 Ceramic Comparisons Between Certain Historic Caddo Sites in Nacogdoches County, Texas: Henry M. (41NA60), Spradley (41NA206), and Deshazo (41NA27). Journal of Northeast Texas Archaeology 31:9599.

2009 (assembler) Classics in Texas Archeology: Selected Articles from the Early Years of the Bulletin of the Texas Archeological Society, Volume 1: Caddo Archeology. Gustav's Library, Davenport, lowa. 321 pp.

2009 Foreword: A Current Perspective on Caddo Archeology. In Classics in Texas Archeology: Selected Articles from the Early Years of the Bulletin of the Texas Archeological Society, Volume 1: Caddo Archeology, 
assembled by Timothy K. Perttula, pp. 5-17. Gustav's Library, Davenport, lowa.

2009 Foreword: Alex D. Krieger and Caddo Archaeology. In Archeological Horizons in the so-called Caddo Area, by Alex D. Krieger, pp. v-ix. Archival Series 3. Texas Archeological Research Laboratory, The University of Texas at Austin.

2009 Foreword to the 2009 Reprint Edition. In The Belcher Mound: A Stratified Caddoan Site in Caddo Parish, Louisiana, by Clarence H. Webb, pp. 1-9. Gustav's Library, Davenport, lowa.

2010 (assembler) Studies on the Instrumental Neutron Activation Analysis of Woodland Period and Caddo Tradition Ceramics from Eastern Texas. Special Publication No. 17. Friends of Northeast Texas Archaeology, Pittsburg and Austin.

2010 Documentation of Caddo Ceramic Vessel Sherds from the Shelby Site (41CP71) in the Vernon Holcomb Collection, Camp County, Texas. Journal of Northeast Texas Archaeology 33:25-29.

2010 Selected Prehistoric Caddo Sites in the Upper Sabine River Basin of Northeast Texas. Journal of Northeast Texas Archaeology 33:41-52.

2010 Archaeological Findings from an Historic Caddo Site (41AN184) in Anderson County, Texas. Journal of Northeast Texas Archaeology 33:5361.

2010 Analysis of the Prehistoric Caddo Ceramics from 41LR351, Lamar County, Texas. Journal of Northeast Texas Archaeology 33:69-91.

2010 Analysis of Prehistoric Artifacts from 2003 Excavations at the George C. Davis Site (41CE19), Cherokee County, Texas. Journal of Northeast Texas Archaeology 33:63-67.

2010 Archaeological Survey along El Camino Real de los Tejas National Historic Trail to Identify $17^{\text {th }}$-Early $19^{\text {th }}$ Century Caddo Sites in East Texas. El Correo, Newsletter of El Camino Real de los Tejas National Historic Trail Association I(5):2-4.

2010 (editor) Proceedings of the Ninth Caddoan Conference, February 4 and 5, 1966, Natchitoches, Louisiana. Caddo Archeology Journal 20:147-191.

2010 Papers on Geophysical Investigations of Woodland and Caddo Sites in the Caddo Area of the Southeastern United States. Southeastern Archaeology 29(2):233-235. 
2010 Woodland and Caddo Ceramic Traditions in East Texas. In Regional Summaries of Prehistoric and Early Historic Ceramics in Texas for the Council of Texas Archeologists, assembled and edited by L. W. Ellis and T. K. Perttula, pp. 13-41. CTA Ceramics Protocol Committee, Council of Texas Archeologists, Austin.

2011 Analysis of the Prehistoric Artifacts from the Pace McDonald Site (41AN51), Anderson County, Texas. Journal of Northeast Texas Archaeology 34:35-54.

2011 Notes on the Hudnall-Pirtle Site (41RK4) in the Buddy Calvin Jones Collection at the Gregg County Historical Museum. Journal of Northeast Texas Archaeology 34:79-82.

2011 The Ceramic Artifacts from the Lang Pasture Site (41AN38) and the Place of the Site within an Upper Neches River Basin Caddo Ceramic Tradition. In Archeological Investigations at the Lang Pasture Site (41AN38) in the Upper Neches River Basin of East Texas, assembled and edited by T. K. Perttula, D. B. Kelley, and R. A. Ricklis, pp. 145-320. Archeological Studies Program Report No. 129, Texas Department of Transportation, Environmental Affairs Division, Austin.

2011 A Radiocarbon Date from a Middle Caddo Period Habitation Site on Hickory Creek, Houston County, Texas. Caddo Archeology Journal 21:147-156.

2011 (assembler) Archaeological and Archaeogeophysical Investigations at an Early Caddo Mound Center in the Sabine River Basin of East Texas, Special Publication No. 15. Friends of Northeast Texas Archaeology, Austin and Pittsburg.

2011 A Cache of Maud Arrow Points and Other Artifacts from the Jim Clark site, Red River County, Texas. Journal of Northeast Texas Archaeology 35:510.

2011 Another Look at the Grace Creek \#1 Site in Gregg County, Texas, as Seen Through Ceramic Analysis. Journal of Northeast Texas Archaeology 35:11-46.

2011 The Pipe Site, a Late Caddo Site at Lake Palestine in Anderson County, Texas. Journal of Northeast Texas Archaeology 35:47-80.

2012 A Caddo Archeology Map. Caddo Archeology Journal 22:17-20. 
2012 Watershed Times for the Caddo Peoples of the Far Southeast. Caddo Archeology Journal 22:97-113.

2012 Three Mounds Creek Site, Gregg County, Texas. Journal of Northeast Texas Archaeology 36:33-36.

2012 Documentation of a Collection from the Poole Site (41TT47) in the Big Cypress Creek Basin in East Texas. Journal of Northeast Texas Archaeology 36:37-41.

2012 Analysis of Ceramic Sherds from the Mid- $18^{\text {th }}$ Century Gilbert Site on Lake Fork Creek, Rains County, Texas. Journal of Northeast Texas Archaeology 37:1-22.

2012 The Archaeology of the Caddo in Southwest Arkansas, Northwest Louisiana, Eastern Oklahoma, and East Texas: An Introduction to the Volume. In The Archaeology of the Caddo, edited by T. K. Perttula and C. P. Walker, pp. 1-25. University of Nebraska Press, Lincoln.

2012 The Character of Fifteenth- to Seventeenth-Century Caddo Communities in the Big Cypress Creek Basin of Northeast Texas. In The Archaeology of the Caddo, edited by T. K. Perttula and C. P. Walker, pp. 363-410. University of Nebraska Press, Lincoln.

2012 How Texas Historians Write About the Pre-A.D. 1685 Caddo Peoples of Texas. Southwestern Historical Quarterly CXV(4):364-376.

2012 The Margaret Elizabeth Ross Hinton Collection of Caddo Artifacts. Texas Archeology 56(3):15-18.

2012 Risky Business: Caddo Farmers Living at the Edge of the Eastern Woodlands. Bulletin of the Texas Archeological Society 83:81-97.

2012 Documentation of Archaeological Materials from the Cherokee Lake Site (41RK132), Rusk County, Texas. Journal of Northeast Texas Archaeology 38:21-29.

2012 An Analysis of the Aboriginal Ceramic Sherds from the Bowmer Site (41BL116) and the Bowmer 3 Site (41BL110), Bell County, Texas. Archeological Journal of the Texas Prairie-Savannah 2:38-59.

2012 Long Unreported Artifact Collections from Spanish Fort Bend Wichita Indian Sites in Oklahoma and Texas. Plains Anthropologist 57(221):63-69. 
2013 Analysis of a Small Sample of Caddo Ceramic Sherds from the T. M. Sanders Site (41LR2), Lamar County, Texas. Journal of Northeast Texas Archaeology 39:1-5.

2013 Analysis of the Prehistoric Artifact Assemblage of Ceramic and Lithic Artifacts from 41LR351, Lamar County, Texas. Journal of Northeast Texas Archaeology 39:7-41.

2013 Caddo Ceramics in East Texas. Bulletin of the Texas Archeological Society $84: 181-212$.

2013 Woodland Period Archaeology as seen from the Attoyac Bayou Basin in East Texas. Caddo Archeology Journal 23:5-26.

2013 Caddo Populations in Northeast Texas: A Response to Taylor and Creel. American Antiquity 78(1):195-196.

2013 Analysis of a Surface Collection from the L. A. Hale (41TT12) Mound Site, Titus County, Texas. Journal of Northeast Texas Archaeology 40:27-30.

2013 The Linebarger Site on Dry Creek, Camp County, Texas. Journal of Northeast Texas Archaeology 40:31-34.

2013 The Chasteen Site (41UR18) on Big Cypress Creek, Upshur County, Texas. Journal of Northeast Texas Archaeology 40:35-38.

2013 Analysis of Surface Collections from Areas A and B at the Sam Roberts Site (41CP8) on Prairie Creek, Camp County, Texas. Journal of Northeast Texas Archaeology 40:39-46.

2013 The Sam D. Carpenter Garden Plot Site (41CP496), Camp County, Texas. Journal of Northeast Texas Archaeology 40:47-52.

2013 Aboriginal Ceramic Sherds from 41MA30 in the Navasota River Basin in Madison County, Texas. Journal of Northeast Texas Archaeology 40:5356.

2013 Analysis of a Collection of Early Caddo Artifacts from the Davis-McPeek Mound Site (41UR4/99), Upshur County, Texas. Journal of Northeast Texas Archaeology 40:57-60.

2013 Additional Ancestral Caddo Ceramic and Lithic Artifacts from the Three Mounds Creek Site, Gregg County, Texas. Journal of Northeast Texas Archaeology 40:61-63. 
2013 Risky Business: Caddo Farmers living at the Edge of the Eastern Woodlands. In Comparative Archaeology and Paleoclimatolgy: Sociocultural responses to a changing world, edited by M. O. Baldia, T. K. Perttula, and D. S. Frink, pp. 21-34. BAR International Series 2456. Archaeopress, Oxford, England.

2013 Foreword to the 2013 Reprint Edition. In The George C. Davis Site, Cherokee County, Texas, by H. Perry Newell and Alex D. Krieger, pp. 515. Gustav's Library, Davenport, lowa.

2013 The Tom Hanks Site (41CP239): A Late Caddo, Titus Phase Mound Site in the Big Cypress Creek Basin, Camp County, Texas. Journal of Northeast Texas Archaeology 41:17-26.

2013 The Sam D. Carpenter Bottom Site (41CP495) in the Big Cypress Creek Basin, Camp County, Texas. Journal of Northeast Texas Archaeology 42:1-21.

2013 The McMinn Ranch Site (41CP72) in the Dry Creek Valley, Camp County, Texas. Journal of Northeast Texas Archaeology 42:23-32.

2013 Aboriginal Ceramic Sherds from Three Sites Along the Navasota River in Madison County, Texas. La Tierra 39:63-69.

2013 Investigations at Two Prehistoric Sites along Boggy Creek in the Post Oak Savannah of East Central Texas. La Tierra 39:81-95.

2014 The Horton Site (41CP16) on Big Cypress Creek in the East Texas Pineywoods. Journal of Northeast Texas Archaeology 43:27-43.

2014 The Lizzie Hill Site (41CP494), Camp County, Texas. Journal of Northeast Texas Archaeology 43:44-62.

2014 Glade Creek at Oil Lease Grave Site, Gregg County, Texas. Journal of Northeast Texas Archaeology 44:21-22.

2014 Eagle Burials on Red River Caddo Sites. http://crhrarchaeology.wordpress.com/2014/02/06/eagle-burials-on-redriver-caddo-sites-perttula/

2014 Hot Rock Cooking in Archaic and Woodland Period Sites in the Western Ouachita Mountains of Southeast Oklahoma. Bulletin of the Oklahoma Anthropological Society LXI:79-106.

2014 The Ceramic Sherd Assemblage from the Boatstone Site in Gregg County, Texas. Journal of Northeast Texas Archaeology 45:1-4. 
2014 A Woodland Period Ceramic Assemblage from Rabbit Creek in the Sabine River Basin, Gregg County, Texas. Journal of Northeast Texas Archaeology 45:5-7.

2014 The Caddo Ceramics from Three Sites on Hawkins Creek in the Sabine River Basin, Gregg County, Texas. Journal of Northeast Texas Archaeology 45:23-30.

2014 The Sipes' Home Site (41RK603): A Late $18^{\text {th }}$ to Early $19^{\text {th }}$ Century Caddo Site on Martin Creek in Rusk County, Texas. Journal of Northeast Texas Archaeology 45:31-37.

2014 Archaeological Studies of the Hatchel Site (41BW3) on the Red River in Bowie County, Texas. Special Publication No. 23. Friends of Northeast Texas Archaeology, Austin and Pittsburg.

2014 The Classification of Late Caddo Period Utility Ware Jars from Sites in the Big Cypress Basin of East Texas. Caddo Archeology Journal 24:53-74.

2014 The Ear Spool Site (41TT653): A mid-15 th to early $17^{\text {th }}$ Century A.D. Caddo Site in the Sulphur River Basin, Titus County, Texas. Caddo Archeology Journal 24:87-116

2014 Caddo Ceramics from Mound Deposits at the Shelby Mound Site (41CP71) on Greasy Creek, Camp County, Texas. Journal of Northeast Texas Archaeology 46:7-43.

2014 The Caddo Ceramic and Lithic Assemblage from the Robert Griffin Site (41SY41), Shelby County, Texas. Center for Regional Heritage Research, Research Report No. 1. Stephen F. Austin State University, Nacogdoches.

2014 The Caddo Ceramic Assemblage from the Buddy Hancock Site (41SY45), Shelby County, Texas. Center for Regional Heritage Research, Research Report No. 2. Stephen F. Austin State University, Nacogdoches.

2014 Other Artifacts from the Morse Mound Site (41SY27), Shelby County, Texas. Center for Regional Heritage Research, Research Report No. 4. Stephen F. Austin State University, Nacogdoches.

2014 The Joe M. Smith Collection from the Roseborough Lake Site (41BW5), Bowie County, Texas. Journal of Northeast Texas Archaeology 47:17-20.

2014 The Distribution of Negative Painted Pottery in the Caddo Area. Journal of Northeast Texas Archaeology 47:21-24. 
2014 The Caddo Archaeology of the Musgano Site in the Sabine River Basin of East Texas. Special Publication No. 28. Friends of Northeast Texas Archaeology, Pittsburg and Austin.

2014 (editor and contributor) The Eli Moores Site, a $17^{\text {th }}$ to early $18^{\text {th }}$ Century Caddo Site on the Red River, Bowie County, Texas. Special Publication No. 31. Friends of Northeast Texas Archaeology, Pittsburg and Austin.

2014 The Mitchell Site (41BW4): An Ancestral Caddo Settlement and Cemetery on McKinney Bayou, Bowie County, Texas. Special Publication No. 32. Friends of Northeast Texas Archaeology, Pittsburg and Austin.

2014 The Hale and Keith Mounds in the Big Cypress Creek Basin in East Texas. Special Publication No. 33. Friends of Northeast Texas Archaeology, Pittsburg and Austin.

2015 East Texas Caddo Ceramic Sherd Database. Journal of Northeast Texas Archaeology 51:1-46.

2015 The Caddo Ceramic Assemblage from the Hardin A Site (41GG69) on the Sabine River in Gregg County, Texas. Journal of Northeast Texas Archaeology 51:47-70.

2015 The Harling Site (41FN1): An Ancestral Caddo Mound Site on the Red River in Fannin County, Texas. Journal of Northeast Texas Archaeology 51:71-84.

2015 The Womack Site (41LR1), an Ancestral Caddo Settlement on Red River in Lamar County, Texas. Journal of Northeast Texas Archaeology 52:1-38.

2015 The Bert W. Davis Site (41HP3) on the South Sulphur River in Hopkins County, Texas. Journal of Northeast Texas Archaeology 52:43-49.

2015 The Goss Farm Site (41FN12) on Bois d'Arc Creek, Fannin County, Texas. Journal of Northeast Texas Archaeology 52:51-58.

2015 The T. N. Coles Site (41RR3): An Early Caddo Period Burial Mound Site on the Sulphur River, Red River County, Texas. Journal of Northeast Texas Archaeology 52:59-71.

2015 The R. L. Jaggers Site (41FK3): An Early Caddo Period Settlement and Cemetery in the Sulphur River Basin, Franklin County, Texas. Journal of Northeast Texas Archaeology 52:73-87.

2015 The T. M. Joslin Site (41VN3) in the Sabine River Basin, Van Zandt County, Texas. Journal of Northeast Texas Archaeology 52:89-98. 
2015 The Westerman Mound Site (41HO15), Houston County, Texas. Journal of Northeast Texas Archaeology 52:99-106.

2015 The Colony Church Site (41RA31): A Caddo Mound Center in the Upper Sabine River Basin, Rains County, Texas. Journal of Northeast Texas Archaeology 52:107-114.

2015 The Joe Meyer Estate \#1 Site (41SM73) on Saline Creek in the Upper Neches River Basin in East Texas. Journal of Northeast Texas Archaeology 53:1-9.

2015 A Titus Phase Midden Mound at the Earl Jones Farm (41WD3) in the Lake Fork Creek Basin, Wood County, Texas. Journal of Northeast Texas Archaeology 53:11-21.

2015 The L. L. Winterbauer Site (41WD6), Wood County, Texas. Journal of Northeast Texas Archaeology 53:23-35.

2015 The A. C. Gibson Site (41WD1), a Middle Caddo Period Component on the Sabine River in Wood County, Texas. Journal of Northeast Texas Archaeology 53:37-46.

2015 The Lafitte Mound Site (41SY15) in the Middle Sabine River Basin, Shelby County, Texas. Journal of Northeast Texas Archaeology 53:47-50.

2015 Upper Sabine River Basin Caddo Mound Sites: The Seaton Bros. (41RA38) and Fruitvale (41VN35) Sites in Rains and Van Zandt Counties, Texas. Journal of Northeast Texas Archaeology 53:51-55.

2015 The Temporal and Spatial Distribution of Catlinite and Redstone Pipes on Caddo Sites. Journal of Northeast Texas Archaeology 53:57-63.

2015 Caddo Archaeological Sites on San Pedro Creek in Houston County, Texas: San Pedro de los Nabedaches. Journal of Northeast Texas Archaeology 53:65-82.

2015 The Peterson Ranch Site (41HS253), A Late $17^{\text {th }}$ to Early $18^{\text {th }}$ Century Ancestral Caddo Cemetery in the Little Cypress Creek Basin, Harrison County, Texas. Journal of Northeast Texas Archaeology 54:1-7.

2015 The Keasler site (41HS235), a Titus Phase Cemetery in the Little Cypress Creek Basin, Harrison County, Texas. Journal of Northeast Texas Archaeology 54:9-19. 
2015 41HS144, A Middle Caddo Period Settlement and Cemetery in the Sabine River Basin of East Texas. Journal of Northeast Texas Archaeology 54:21-34.

$201541 \mathrm{HO} 70$ on Stowe Creek in the upper San Pedro Creek Basin, Houston County, Texas. Journal of Northeast Texas Archaeology 54:35-40.

2015 Two Caddo Sites in the Attoyac Bayou Basin in the East Texas Pineywoods, San Augustine County, Texas. Journal of Northeast Texas Archaeology 54:41-53.

2015 Armstrong Landing Site (41CS37): An Ancestral Caddo Site on the Sulphur River, Cass County, Texas. Journal of Northeast Texas Archaeology 54:55-62.

2015 Caddo Sites on Patroon, Palo Gaucho, and Housen Bayous in Sabine County in the Sabine River Basin of East Texas. Journal of Northeast Texas Archaeology 54:63-91.

2015 The Coker Mound (41CS1) in the Sulphur River Basin of East Texas. Journal of Northeast Texas Archaeology 55:1-4.

2015 The Stover Lake Site (41BW8) on the lower Sulphur River, Bowie County, Texas. Journal of Northeast Texas Archaeology 55:5-17.

2015 Ancestral Caddo Sites in the lower Sulphur River Basin at Lake Wright Patman, Bowie and Cass Counties, Texas. Journal of Northeast Texas Archaeology 55:19-25.

2015 The Forest Mound Site (41CE290) on Larrison Creek, Cherokee County, Texas. Journal of Northeast Texas Archaeology 55:27-31.

2015 The Brooks-Lindsey Site (41CE293), a Probable Post-A.D. 1650 Caddo Site in the Neches River Basin, Cherokee County, Texas. Journal of Northeast Texas Archaeology 55:33-36.

2015 The Frank Murphy Farm Site (41AN48), Anderson County, Texas. Journal of Northeast Texas Archaeology 55:37-45.

2015 The Doug Martin Site (41AN88), a Late Caddo Period Frankston Phase Settlement in the Trinity River Basin in East Texas. Journal of Northeast Texas Archaeology 55:47-55.

2015 41AN28: An Ancestral Caddo Settlement on Mound Prairie Creek in the Neches River Basin in East Texas. Journal of Northeast Texas Archaeology 55:57-69. 
2015 Some Ancestral Caddo Sites on Bayou Loco in the Angelina River Basin, Nacogdoches County, Texas. Journal of Northeast Texas Archaeology 55:77-88.

2015 Caddo Ceramic Vessels from the Hatchel Site (41BW3) on the Red River in Bowie County, Texas. Special Publication No. 39. Friends of Northeast Texas Archaeology, Austin and Pittsburg.

2015 Caddo Ceramic Vessels from the Goode Hunt (41CS23) and Clements (41CS25) Sites in the East Texas Pineywoods. Special Publication No. 42. Friends of Northeast Texas Archaeology, Pittsburg and Austin.

2015 Diversity in Ancestral Caddo Vessel Forms in East Texas Archaeological Sites. Journal of Northeast Texas Archaeology 56:1-17.

2015 The J. M. Snow Site (41CE8) in the Neches River Basin, Cherokee County, Texas. Journal of Northeast Texas Archaeology 57:79-81.

2016 Bison Remains and Tools on East Texas and Northwest Louisiana Caddo Sites. Journal of Northeast Texas Archaeology 58:15-34.

2016 Prairie Caddo Sites in Coryell and McLennan Counties in Central Texas. Journal of Northeast Texas Archaeology 58:41-66.

2016 (with contributions by W. Troell) The A. S. Mann (41HE7) and M. S. Roberts (41HE8) Sites in the Upper Neches River Basin, Henderson County, Texas. Journal of Northeast Texas Archeology 59:1-19.

2016 The Caddo Ceramic Sherd Assemblage from the W. T. Robinson Farm (41AN4), Anderson County, Texas. Journal of Northeast Texas Archeology 59:21-24.

2016 A Late Caddo Period Vessel from the De Long Farm Site (41AN16) in the Upper Neches River Basin, Anderson County, Texas. Journal of Northeast Texas Archeology 59:25-28.

2016 The Wollard \#2 Site (41HE22) in the Upper Neches River Basin, Henderson County, Texas. Journal of Northeast Texas Archeology 59:2938.

2016 Ancestral Caddo Ceramic Vessels from the J. B. Sparkman Site (41HP26), Hopkins County, Texas. Journal of Northeast Texas Archeology 59:39-42. 
2016 The Frank Norris Farm Site (41RR2) on the Red River in East Texas. Journal of Northeast Texas Archeology 59:43-64.

2016 Two Radiocarbon Dates from the Salt Lick Site (16SA37a) at Toledo Bend Reservoir, Sabine Parish, Louisiana. Journal of Northeast Texas Archeology 59:65-67.

2016 The W. A. Ford Site (41TT2), Titus County, Texas. Journal of Northeast Texas Archaeology 60:1-52.

2016 Eagle Burials on Red River Caddo Sites. Journal of Northeast Texas Archaeology 60:95-97.

2016 A Ceramic Sherd Assemblage from a Caddo Site in the Upper Neches River Basin, Henderson County, Texas. Journal of Northeast Texas Archaeology 61:1-10.

2016 An Artifact Assemblage from Area B at the Grace Creek Site (41GG33), Gregg County, Texas. Journal of Northeast Texas Archaeology 61:11-15.

2016 Ceramic Sherds from the Millsey Williamson Site (41RK3), Rusk County, Texas. Journal of Northeast Texas Archaeology 61:17-20.

2016 Caddo Ceramic Assemblage from a Site Across the Road from the Millsey Williamson Site in Rusk County, Texas. Journal of Northeast Texas Archaeology 61:21-27.

2016 An Ancestral Caddo Site on Mill Creek in Rusk County, Texas. Journal of Northeast Texas Archaeology 61:29-33.

2016 Ceramic Sherd Assemblage from the Cherokee Lake Site (41RK132), Rusk County, Texas. Journal of Northeast Texas Archaeology 61:35-38.

2016 Caddo Ceramic Sherd Assemblage from a Hearth Feature at the Cherokee Lake Site (41RK132) in Rusk County, Texas. Journal of Northeast Texas Archaeology 61:39-43.

2016 The Oil Road Site in Rusk County, Texas. Journal of Northeast Texas Archaeology 61:45-49.

2016 The E. Williams Site on Martin Creek in Panola County, Texas. Journal of Northeast Texas Archaeology 61:51-54.

2016 Bird Bone Flageolet from the Walter Bell Site (41SB50) at Lake Sam Rayburn, Sabine County, Texas. Journal of Northeast Texas Archaeology 62:31-35. 
2016 Syntheses of the Caddo Archaeological Record. Caddo Archeology Journal 26:5-6.

2016 Ancestral Caddo Ceramic Vessels from the McDonald Site, McCurtain County, Oklahoma. Oklahoma Anthropological Society Bulletin 63:77-83.

2016 WPA Archaeology in East Texas: Recent Studies. History of Archaeology Interest Group Newsletter 6(1):2-16.

2016 Caddo Ceramic Vessels from the Eli Moores Site (41BW2), Bowie County, Texas. Journal of Northeast Texas Archaeology 63:1-15.

2016 New Radiocarbon Dates from Four East Texas Caddo Sites. Journal of Northeast Texas Archaeology 63:17-21.

2016 Early Caddo Period Ceramic Vessels from the Roger D. Simmons Site (41TT321), Titus County, Texas. Journal of Northeast Texas Archaeology 63:57-61.

2016 Caddo Ceramic Vessels from the W. J. Barnett Site (41SM2), Smith County, Texas. Journal of Northeast Texas Archaeology 63:133-136.

2016 Caddo Ceramic Vessels from the Joseph Fabion (41SY24) and S. H. Latham (41SY25) Sites in Shelby County, Texas. Journal of Northeast Texas Archaeology 63:137-145.

2016 Caddo Ceramic Vessels from the Fred Yarbrough Site (41VN6) in the Upper Sabine River Basin, Van Zandt County, Texas. Journal of Northeast Texas Archaeology 64:1-12.

2016 Archaeological Evidence of the Use of the Horse by Caddo Indian Peoples. Journal of Northeast Texas Archaeology 64:13-17.

2016 Documentation of Early Caddo Period Ceramic Vessels from the George C. Davis Site on the Neches River in Cherokee County, Texas. Journal of Northeast Texas Archaeology 64:25-79.

2016 Caddo Vessels from the Susie Slade Site (41HS13), Harrison County, Texas. Journal of Northeast Texas Archaeology 64:81-91.

2016 Caddo Vessels from the W. O. Ziegler Farm (41WD30) and Claude Burkett (41WD31) Sites in the Upper Sabine River Basin in Wood County, Texas. Journal of Northeast Texas Archaeology 64:93-97. 
2016 Documentation of the Caddo Ceramic Vessels from the Culpepper Site (41HP1) in Hopkins County in the Upper Sulphur River Basin in East Texas. Journal of Northeast Texas Archaeology 65:53-98.

2016 Ceramic Sherd Assemblages from the Hawkins Bluff (41CS2), Snipes (41CS8), and 41CS44 Sites on the lower Sulphur River at Lake Wright Patman, Cass County, Texas. Journal of Northeast Texas Archaeology 66:1-11.

2016 The Caddo Ceramic Sherd Assemblage from the Hawkins Site (41SM144) on the Sabine River in Smith County, Texas. Journal of Northeast Texas Archaeology 66:13-19.

2016 Analysis of a 1940 Caddo Sherd Assemblage from the Millsey Williamson Site (41RK3), Rusk County, Texas. Journal of Northeast Texas Archaeology 66:31-34.

2016 The 7-J Ranch Site (41HO4) in the Post Oak Savannah of East Texas, Houston County, Texas. Journal of Northeast Texas Archaeology 66:3537.

2016 41SM91: A Frankston Phase Settlement on the Neches River at Lake Palestine, Smith County, Texas. Journal of Northeast Texas Archaeology 66:39-45.

2016 Caddo Ceramic Sherds from Leon River Valley Sites in Coryell County, Texas. Journal of Northeast Texas Archaeology 66:51-58.

2016 Native American Ceramic Assemblages from Sites in Tyler County in Southeast Texas. Journal of Northeast Texas Archaeology 66:59-67.

2016 41CE291: An Historic Caddo Settlement in the Neches River Valley in East Texas. Journal of Northeast Texas Archaeology 66:69-75.

2016 The Caddo Occupation of the L. B. Miller Farm (41HE4/55) in the Post Oak Savanna and Trinity River Basin in East Texas. Journal of Northeast Texas Archaeology 66:77-83.

2016 New Radiocarbon Dates from Ancestral Caddo Sites in Cherokee, Fannin, Hopkins, Nacogdoches, and Wood Counties, Texas. Journal of Northeast Texas Archaeology 67:1-5.

$201618^{\text {th }}$ Century Mexican Majolica Sherds from the George C. Davis Site (41CE19), Cherokee County, Texas. Journal of Northeast Texas Archaeology 67:15-19. 
2016 Ancestral Caddo Ceramic Vessel Sherd Studies: Buddy Calvin Jones Sites in East Texas. Journal of Northeast Texas Archaeology 67:21-38.

2016 The De Rossett Farm (41HE75) and Quate Place (41HE81) Sites in the Cobb Creek Valley in the Upper Neches River Basin, Henderson County, Texas. Journal of Northeast Texas Archaeology 67:39-53.

2016 The Newt Smith Site (41HE78), Henderson County, Texas. Journal of Northeast Texas Archaeology 67:55-56.

2016 Ceramics at Three Ancestral Caddo Sites in the Upper Neches River Basin, Smith County, Texas. Journal of Northeast Texas Archaeology 67:57-70.

2016 Titus Phase Ceramics from the Pine Tree Farm Site (41WD51) in the Lake Fork Creek Basin, Wood County, Texas. Journal of Northeast Texas Archaeology 67:75-78.

2016 Ancestral Caddo Ceramics from Three Sites on Mill Race Creek, Wood County, Texas. Journal of Northeast Texas Archaeology 67:79-84.

2016 The Caddo Archaeology of the San Pedro Creek Valley, Houston County, in East Texas. Journal of Northeast Texas Archaeology 68:1-72.

2016 The Caddo Archaeological Record in the Saline Creek and County Line Creek Valleys in Cherokee and Smith Counties, Texas. Journal of Northeast Texas Archaeology 69:1-71.

2016 41SM150: A Middle Caddo Period Site in the Angelina River Basin, Smith County, Texas. Journal of Northeast Texas Archaeology 70:1-12.

2016 Caddo Ceramic Assemblages from Sites in the Ayish and Palo Gaucho Bayou Basins, San Augustine County, Texas. Journal of Northeast Texas Archaeology 70:13-31.

2016 Ancestral Caddo Ceramic Artifacts in the Jesse Martin Glasco Collection from Upshur County, Texas, at the National Museum of Natural History, Smithsonian Institution. Journal of Northeast Texas Archaeology 70:39-42.

2016 Upper Neches River Basin Caddo Ceramic Vessels from Anderson, Cherokee, and Henderson Counties in East Texas. Journal of Northeast Texas Archaeology 70:43-60.

2016 Utility Ware Ceramic Metrics and Hasinai Caddo Archaeology in East Texas. Journal of Northeast Texas Archaeology 70:61-68. 
2016 Documentation of Artifacts from Sam Whiteside Collection from Sites in the Sabine and Neches River Basins, Upshur, Smith, and Cherokee Counties, Texas. Journal of Northeast Texas Archaeology 70:69-76.

2016 Radiocarbon Dates from the Pine Snake Site (41CE467), Cherokee County, Texas. Journal of Northeast Texas Archaeology 70:111-114.

2016 Ancestral Caddo Ceramic Vessels from the Wright Plantation (41RR7) and Rowland Clark (41RR77) Sites in the Harris Collection at the National Museum of Natural History, Smithsonian Institution. Journal of Northeast Texas Archaeology 70:115-119.

2016 Caddo Ceramic Vessels from the Sam Kaufman Site (41RR16) in the R. K. Harris Collection at the National Museum of Natural History, Smithsonian Institution. Journal of Northeast Texas Archaeology 70:121127.

2016 Selected Ceramic Analyses of the George C. Davis Site (41CE19) Ceramic Assemblage. Letter Report No. 343. Archeological \& Environmental Consultants, LLC, Austin.

2017 Documenting East Texas Caddo Pottery in Central Texas. The Newsletter of The Friends of the Texas Archeological Research Laboratory (March 2017):4.

2017 Current Archeological Research in East Texas: Documentation of WPAGus Arnold Archeological Survey Collections. Caddo Archeology Journal 27:100-101.

2017 1939-1940 WPA Archaeological Collections from Ancestral Caddo Sites in Nacogdoches County, Texas. Journal of Northeast Texas Archaeology 71:61-74.

2017 The Kinsloe Site (41GG3) on Rabbit Creek in the mid-Sabine River Basin, Gregg County, Texas. Journal of Northeast Texas Archaeology 71:75-90.

2017 Early Sixteenth Century Caddo Population Distributions. Journal of Northeast Texas Archaeology 71:99-104.

2017 The Ancestral Caddo Ceramic Assemblage from the D. W. Moye Site (41JP3) on the Angelina River, Jasper County, Texas. Journal of Northeast Texas Archaeology 71:91-97.

2017 The Beckham (41SB35) and Print Bell (41SB36) Woodland Period and Caddo Ceramic Assemblages Collected by G. E. Arnold in 1939, Sabine County, Texas. Journal of Northeast Texas Archaeology 71:135-146. 
2017 Caddo Ceramic Vessel Database from Sites in Texas, Louisiana, Oklahoma, and Arkansas. Journal of Northeast Texas Archaeology 71:123-134.

2017 The Bonner Place (41AG3) and J. A. Jordan (41AG5) Sites in the Neches River Basin, Angelina County, Texas. Journal of Northeast Texas Archaeology 71:147-154.

2017 The J. B. Maxwell Site (41CE43) in the Mud Creek Basin, Cherokee County, Texas. Journal of Northeast Texas Archaeology 71:155-159.

2017 Radiocarbon Dates from Aboriginal Sites in Cherokee, Henderson, and Tyler Counties in East Texas. Journal of Northeast Texas Archaeology 71:161-164.

2017 Analysis of Ancestral Caddo Ceramic Assemblages from the Gas Line Site (41CE63) and 41CE289, Neches River Basin, Cherokee County, Texas. Journal of Northeast Texas Archaeology 72:43-49.

2017 An Historic Caddo Burial at the Swen Farm Site (41BW65), Bowie County, Texas. Journal of Northeast Texas Archaeology 72:51-52.

2017 41AG9 and 41AG10: Ancestral Caddo Sites on Percella Creek in the Angelina River Basin in East Texas. Journal of Northeast Texas Archaeology 72:53-61.

2017 The Ancestral Caddo Ceramic Assemblage from the Will Odham Site (41CE42) in the Angelina River Basin, Cherokee County, Texas. Journal of Northeast Texas Archaeology 72:63-73.

2017 Artifact Assemblages from San Augustine County, Texas, Sites Recorded in 1939-1940 by Gus E. Arnold. Journal of Northeast Texas Archaeology 72:75-134.

2017 Ancestral Caddo Ceramic Sherds from 2016 Investigations at 41MR211, Marion County, Texas. Journal of Northeast Texas Archaeology 72:135137.

2017 Ancestral Caddo Ceramic Vessels from the Tom Shumate Site (41RK2), Rusk County, Texas. Journal of Northeast Texas Archaeology 72:139144.

2017 The Caddo Ceramic Vessels from the Cemetery at 41HS74 on Hatley Creek in the Sabine River Basin, Harrison County, Texas. Journal of Northeast Texas Archaeology 72:145-168. 
2017 Caddo Landscapes in the East Texas Forests. Oxbow Books, Oxford, England.

2017 The Harold Nix Site in Morris County, Texas: A Late Titus Phase Cemetery on Boggy Creek in the Big Cypress Creek Basin. Journal of Northeast Texas Archaeology 73:65-78.

2017 New Radiocarbon Dates from the Sanders Site (41LR2), Lamar County, Texas. Journal of Northeast Texas Archaeology 73:79-80.

2017 The Use of Clay Pigments on Ceramic Vessel Sherds from the Hatchel Site (41BW3) and Comparisons to Ancestral East Texas Caddo Ceramic Vessel Assemblages. Journal of Northeast Texas Archaeology 73:95-102.

2017 The Historic Caddo Component at the Roseborough Lake Site (41BW5) on the Red River in Bowie County, Texas. Journal of Northeast Texas Archaeology 74:1-43.

2017 Artifacts from 41SA38 in the Texas Archeological Research Laboratory Collections. Journal of Northeast Texas Archaeology 74:45.

2017 A Caddo Ceramic Vessel Sherd Collection from a Site in the Upper Neches River Basin, Anderson County, Texas. Journal of Northeast Texas Archaeology 74:81-83.

2017 The Distribution of East Texas Caddo Pottery found in Archaeological Sites in the General Central Texas Region. La Tierra, Vol. 41:69-82.

2017 Documentation of Ancestral Caddo Ceramic Vessels from Sites in Red River County, Texas. Journal of Northeast Texas Archaeology 75:1-13.

2017 Selected Caddo Ceramic Artifacts from the E. H. Buchanan Plantation (41RR5), Bowie County, Texas. Journal of Northeast Texas Archaeology 75:15-17.

2017 Documentation of Ancestral Caddo Ceramic Vessels from the Knight's Bluff (41CS14) and Sherwin (41CS26) Sites, Cass County, Texas. Journal of Northeast Texas Archaeology 75:19-52.

2017 Comments on Aboriginal Ceramic Sherds from Sites at the Proposed Lower Bois d'Arc Creek Reservoir, Fannin County, Texas. Journal of Northeast Texas Archaeology 75:73-77. 
2017 Correspondence between George T. Wright and A. T. Jackson Regarding Late 1930s-Early 1940s Excavations at the Sam Kaufman Site (41RR16). Journal of Northeast Texas Archaeology 75:83-93.

2017 An Ancestral Caddo Ceramic Vessel from the Molly Cameron Site (41BW18) in the Sulphur River Basin in East Texas. Journal of Northeast Texas Archaeology 75:95-97.

2017 Ancestral Caddo Ceramic Vessels from Sites in Nacogdoches and Panola Counties in East Texas. Journal of Northeast Texas Archaeology 75:99104.

2017 A Caddo Ceramic Vessel from the Atkinson Farm Site (41RR1), Red River County, Texas. Journal of Northeast Texas Archaeology 75:105-106.

2017 Late Caddo Titus Phase Ceramics from the McKay Site (41TT730), Titus County, Texas. Journal of Northeast Texas Archaeology 75:111-114.

2017 Documentation of Ancestral Caddo Ceramic Vessels from the Harold Williams Site (41CP10), Camp County, Texas. Journal of Northeast Texas Archaeology 76:71-87.

2017 A Ripley Engraved Vessel from East Texas. Journal of Northeast Texas Archaeology 76:121-123.

Perttula, T. K. (assembler)

2017 Specialized Ceramic Analyses of the George C. Davis Site (41CE19) Ceramic Assemblage, Cherokee County, Texas. Report of Investigations No. 146. Archeological \& Environmental Consultants, LLC, Austin.

Perttula, T. K. and J. C. Blaine

1998 Historic European Trade Goods from the Willis Place \#2 (41BW147) Site in Bowie County, Texas. Journal of Northeast Texas Archaeology 11:9192.

Perttula, T. K. and J. E. Bruseth

1983 Early Caddoan Subsistence Strategies, Sabine River Basin, East Texas. Plains Anthropologist 28(99):9-22.

1995 Trade and Exchange in Eastern Texas, 1100 B.C.-A.D. 800. Louisiana Archaeology 17:93-121.

1998 (Editors) The Native History of the Caddo: Their Place in Southeastern Archeology and Ethnohistory. Studies in Archeology 30. Texas Archeological Research Laboratory, The University of Texas at Austin. 
Perttula, T. K. and R. L. Cast

2010 Defining and Publicizing the Caddo Presence along El Camino Real de los Tejas in East Texas: A Research Strategy to Identify $17^{\text {th }}$-early $19^{\text {th }}$ Century Caddo Sites. Cultural Preservation Program, Caddo Nation of Oklahoma, Binger.

2012 The Term "Arkansas River Basin Caddoan" has Outlived whatever Usefulness it had as a Cultural Taxonomic Term. Plains Anthropologist 56 (220):365-367.

2016 Reaping the Whirlwind: The Caddo after Europeans. Journal of Northeast Texas Archaeology 60:65-93.

Perttula, T. K. and G. W. Cheatwood

2016 Archaeological Sites Along Cuthand Creek and the Sulphur River in the Mid-Sulphur River Basin, Red River County, Texas. Journal of Northeast Texas Archaeology 58:35-40.

Perttula, T. K. and J. B. Cruse

1997 The Caddoan Archaeology of the Sabine River during the Middle Caddoan Period. Journal of Northeast Texas Archaeology 9:30-37.

Perttula, T. K. and L. W. Ellis

2012 The Hickory Hill Site (41CP408): Archeological Investigations at a Middle Caddo Site in the Little Cypress Creek Basin in East Texas. Document No. 120055. Atkins Group, Austin.

2013 Aboriginal Ceramics among Groups living in the Prairie Savanna Region of Texas. Bulletin of the Texas Archeological Society 84:113-135.

Perttula, T. K. and J. K. Feathers

2011 Luminescence Dates from the Tuinier Farm Site (41HP237), Hopkins County, Texas. Caddo Archeology Journal 21:157-162.

Perttula, T. K. and J. R. Ferguson

2010 The Chemical Variation in Prehistoric and Early Historic Caddo Ceramics in Eastern Texas. In Studies on the Instrumental Neutron Activation Analysis of Woodland Period and Caddo Tradition Ceramics from Eastern Texas, compiled by T. K. Perttula, pp. 3-1 to 3-62. Special Publication No. 17. Friends of Northeast Texas Archaeology, Pittsburg and Austin.

Perttula, T. K. and K. K. Gilmore 1988 Archaeological Survey along Mill Race Creek and Tributaries, Wood County, Texas: 1987-1988. Contributions in Archaeology No. 6. Institute of Applied Sciences, University of North Texas, Denton. 
Perttula, T. K. and M. D. Glascock

2017 Glass Beads. In La Belle: The Archeology of a Seventeenth-Century Ship of New World Colonization, edited by J. E. Bruseth, A. A. Borgens, B. M. Jones, and E. D. Ray, pp. 509-530. Texas A\&M University Press, College Station.

Perttula, T. K. and L. Green

2006 Marine Shell Disks from Protohistoric Sites on Stouts Creek, Hopkins County, Texas. Journal of Northeast Texas Archaeology 25:19-25.

Perttula, T. K. and T. R. Hester

2016 Obsidian Artifacts in East Texas Archaeological Sites. Journal of Northeast Texas Archaeology 66:85-90.

Perttula, T. K. and P. S. Marceaux 2008 Analysis of the Ouachita National Forest Prehistoric Archeological Site Database, Southwestern Arkansas and Eastern Oklahoma. Report of Investigations No. 91. Archeological \& Environmental Consultants, LLC., Austin.

2011 Archeological Survey Investigations on the Crawford Property and a Portion of the T. M. Sanders Site (41LR2) in the New Proposed Right-ofWay for the Keystone XL Pipeline, Lamar County, Texas. Letter Report No. 280. Archeological \& Environmental Consultants, LLC, Austin.

Perttula, T. K. and P. McGuff

1985 Woodland and Caddoan Settlement in the McGee Creek Drainage, Southeast Oklahoma. Plains Anthropologist 30(109):219-235.

1993 A Cultural Resources Survey of the McGee Creek Project Area, Atoka County, Oklahoma. McGee Creek Archaeological Project Reports Vol. I. Institute of Applied Sciences, University of North Texas, Denton.

Perttula, T. K. and T. Middlebrook

2007 Historic Caddo Archaeology: An Occasional Meeting of the East Texas Caddo Research Group, December 2-3, 2006, in Nacogdoches, Texas. Journal of Northeast Texas Archaeology 26:1-7.

2009 History of the East Texas Caddoan/Caddo Research Group, 1996-2008. Journal of Northeast Texas Archaeology 31:1-9.

2009 Prehistoric Caddo Ceramics from the Henry Lake Site (41CE324), Cherokee County, Texas. Journal of Northeast Texas Archaeology 29:921.

2016 Radiocarbon Dates from the Henry M. Site (41NA60), Nacogdoches County, in East Texas. Journal of Northeast Texas Archaeology 67:71-74. 
Perttula, T. K. and M. M. Miller (editors)

2014 Archeological Investigations at the Kitchen Branch (41CP220), B. J. Horton (41CP20), and Keering (41CP21) Sites, Big Cypress Creek Basin, Camp County, Texas. Final Technical Report, No. 88. AmaTerra Environmental, Inc., Austin.

Perttula, T. K. and R. Nathan

1989 Cultural Resources Survey of the Natural Gas Pipeline of America, Southern Interconnect Pipeline, Lamar, Red River, Franklin, Titus; Morris, and Cass Counties, Texas. Institute of Applied Sciences, University of North Texas, Denton.

Perttula, T. K. and B. Nelson

1997 Second Report on Archeological Investigations at Lake O' the Pines, a U.S. Army Corps of Engineers-Owned Facility in Northeast Texas. Friends of Northeast Texas Archaeology, Pittsburg and Austin.

1997 41HS574, The Coleman Farm Site on Starkey Creek. Journal of Northeast Texas Archaeology 10:52-57.

1997 Construction Damages a Prehistoric Caddo Indian Archaeological Site at the City of Gilmer's Proposed Lake Gilmer, Upshur County, Texas. Journal of Northeast Texas Archaeology 10:69-74.

1998 Titus Phase Mortuary Practices in the Northeast Texas Pineywoods and Post Oak Savanna. In Analysis of the Titus Phase Mortuary Assemblage at the Mockingbird or "Kahbakayammaahin" Site (41TT550), by T. K. Perttula, M. Tate, H. Neff, J. W. Cogswell, M. D. Glascock, E. Skokan, S. Mulholland, R. Rogers, and B. Nelson, pp. 328-401. Document No. 970849. Espey, Huston \& Associates, Inc., Austin.

1998 Archeological Survey Investigations of Selected Parts of the Walker Creek Project Area for Pilgrim's Pride Corporation, Camp County, Texas. Report of Investigations No. 22. Archeological and Environmental Consultants, Austin.

1999 The Looting of Prehistoric Caddo Indian Cemeteries in Northeast Texas. Texas Forum on Civil Liberties \& Civil Rights 4(1):77-86.

1999 Additional Archeological Survey and Shovel Testing Investigations in the Walker Creek Complex Project Area for Pilgrim's Pride Corporation, Camp County, Texas. Report of Investigations No. 23. Archeological and Environmental Consultants, LLC, Austin. 
2000 Archeological Investigations at the Harrison Bayou Site (41HS240) in Harrison County, Texas. Caddoan Archeology 11(3):14-32.

2000 Phase II Archeological Survey Investigations of the City of Tyler-Lake Palestine WTP Project, Smith County, Texas. Report of Investigations No. 41. Archeological and Environmental Consultants, Austin.

2000 Archeological Survey of 1608 Acres at DeGray Lake, Clark and Hot Spring Counties, Arkansas. 2 Vols. Report of Investigations No. 39. Archeological and Environmental Consultants, LLC, Austin.

2000 Archeological Survey of Underground Electric Lines at Shouse Ford Recreation Area, DeGray Lake, Hot Spring County, Arkansas. Letter Report No. 73. Archeological and Environmental Consultants, LLC, Austin.

2001 Archeological Survey of Four Tracts of Land at Lake Ouachita, Garland and Montgomery Counties, Arkansas. Report of Investigations No. 47. Archeological and Environmental Consultants, LLC, Austin.

2001 Archeological Test Excavations at the Prestonwood (41SM272) and Broadway (41SM273) Sites along the City of Tyler-Lake Palestine WTP Project, Smith County, Texas. Report of Investigations No. 43. Archeological and Environmental Consultants, LLC, Austin.

2001 Archeological Investigations at the Camp Joy Mound (41UR144): A Titus Phase Earthen Mound at Lake O' the Pines, Upshur County, Texas. Report of Investigations No. 44. Archeological and Environmental Consultants and Friends of Northeast Texas Archaeology, Austin and Pittsburg.

2002 Archeological Survey of Lake Bob Sandlin State Park, Titus County, Texas. Report of Investigations No. 48. Archeological and Environmental Consultants, LLC, Austin.

2002 An Archeological Survey of Harrison Bayou Lease Lands at the Longhorn Army Ammunition Plant, Harrison County, Texas. Report of Investigations No. 12. Archeological and Environmental Consultants, Austin.

2002 Archeological Investigations at the Frank Benson Site (41TT310), Titus County, Texas. Caddoan Archeology 12(3-4):19-40.

2002 Archeological Survey of 721 Acres at Lake Greeson, Pike County, Arkansas. Report of Investigations No. 54. Archeological and Environmental Consultants, LLC, Austin. 
2003 Temporal and Spatial Patterns in the Prehistoric Settlement of the Lake Bob Sandlin Area, Big Cypress Creek Basin, Northeastern Texas. Caddoan Archeology Journal 13 (No. 2):28-35.

2003 The Nawi haia ina Site (41RK170): Archeological Investigations in the City of Henderson's Southside Wastewater Treatment Plant, Rusk County, Texas. Report of Investigations No. 51. Archeological \& Environmental Consultants, LLC, Austin.

2003 Archeological Investigations of Village Areas at the Hatchel Site (41BW3), Bowie County, Texas. Report of Investigations No. 58. Archeological \& Environmental Consultants, LLC, Austin.

2004 Archeological Investigations at Five Prehistoric Sites at Broken Bow Reservoir, McCurtain County, Oklahoma. Report of Investigations No. 49. Archeological \& Environmental Consultants, LLC, Austin.

2004 Woodland and Caddo Archeology at the Broadway or Kanduts'ah Kuhnihdahahdisa' Site (41SM273) on the City of Tyler-Lake Palestine WTP Project, Smith County, Texas. Report of Investigations No. 50. Archeological \& Environmental Consultants, LLC, Austin.

2004 Archeological Survey of 1180 Acres at DeGray Lake, Clark County, Arkansas. Report of Investigations No. 67. Archeological \& Environmental Consultants, LLC, Austin.

2004 Archeological Survey of 1239 Acres in the Mena/Oden Districts of the Ouachita National Forest, Polk County, Arkansas. Report of Investigations No. 65. Archeological \& Environmental Consultants, LLC, Austin.

2004 Certain Caddo Sites in the Ouachita Mountains of Southwestern Arkansas. Caddoan Archeology Journal 13 (3\&4):21-56.

2005 Archeological Survey Investigations of 1148 Acres in the Mena/Oden and Womble Districts of the Ouachita National Forest, Montgomery and Polk Counties, Arkansas. Report of Investigations No. 75. Archeological \& Environmental Consultants, LLC, Austin.

2005 The Pine Saddle Site (3PL1080) in the Ouachita Mountains, Polk County, Arkansas. Caddoan Archeology Journal 14:65-70.

2006 Test Excavations at Three Caddo Sites at Mission Tejas State Park, Houston County, Texas. Report of Investigations No. 76. Archeological \& Environmental Consultants, LLC, Austin. 
2006 Archaeological Investigations at the Polk Estates Site (41CP245), Camp County, Texas. Journal of Northeast Texas Archaeology 24:1-83.

2007 Archeological Survey Investigations and Test Excavations at 41CE354 at the North and South Lake areas of the H.R.C. Cherokee Tree Farm, L. P. Project, Cherokee County, Texas. Report of Investigations No. 80. Archeological \& Environmental Consultants, LLC, Austin.

2007 Archeological Investigations in 2007 at Mission Tejas State Park in Houston County, Texas. Report of Investigations No. 85. Archeological \& Environmental Consultants, LLC, Austin.

2007 Documentation of a Collection of Archaeological Materials from the Millsey Williamson Site (41RK3), a Historic Nadaco Caddo Settlement. Journal of Northeast Texas Archaeology 26:120-127.

2007 The Gum Creek Cluster: Protohistoric Caddo Sites in the Little Cypress Creek Basin, ca. 1670-1720. Journal of Northeast Texas Archaeology 26:128-135.

2007 Place of the Blackberry: Historic Nabedache Caddo Archeology at Mission Tejas State Park, Houston County, Texas. Current Archeology in Texas $9(1): 1-11$.

2008 Archeological Survey of Additional Lands of the H.R.C. Cherokee Tree Farm, L. P. Project, Cherokee County, Texas. Report of Investigations No. 96. Archeological \& Environmental Consultants, LLC, Austin.

2008 Atlanta State Park, Cass County. In Texas Parks and Wildlife Department 2007 Annual Report to the Texas Historical Commission, edited by M. Strutt, pp. 1-29. Texas Parks and Wildlife Department, Cultural Resources Program, Austin.

2009 Archeological Survey of 361.3 Acres of the H.R.C. Cherokee Tree Farm, L. P. Project in the Flat Creek Valley, Cherokee County, Texas. Report of Investigations No. 98. Archeological \& Environmental Consultants, LLC, Austin.

2009 Prehistoric Artifact Assemblages from Sites along Hickory Creek in the Davy Crockett National Forest, Houston County, Texas. Special Publication No. 14. Friends of Northeast Texas Archaeology, Pittsburg and Austin.

2010 Archaeological Investigations Along James Bayou in Marion County, Texas and Caddo Parish, Louisiana. Journal of Northeast Texas Archaeology 32:1-50. 
2010 Recent Archeological Survey Investigations at Caddo Mounds State Historic Site (George C. Davis Site, 41CE19). Letter Report No. 242. Archeological \& Environmental Consultants, LLC, Austin.

2011 A Prehistoric Caddo Site on Black Fork Creek, Upper Neches River Basin, Smith County, Texas. Journal of Northeast Texas Archaeology 34:67-68.

2011 Archeological Investigations of the Proposed University East Approach Road in the City of Texarkana and Bowie County, Texas. Report of Investigations No. 118. Archeological \& Environmental Consultants, LLC, Austin.

2011 Archeological Survey of Compartments 1 and 2 at the Little River National Wildlife Refuge, McCurtain County, Oklahoma. Native Heritage Preservation Associates, LLC, Anadarko, Oklahoma.

2012 The Caddo Ceramic Assemblage from the New Hope Site (41FK107), Franklin County, Texas. Journal of Northeast Texas Archaeology 38:4571.

2012 The Wa'akas Site (41CP490) at Lake Bob Sandlin, Camp County, Texas. Journal of Northeast Texas Archaeology 38:73-83.

2012 Archeological Survey Investigations of a 1.25 Mile River Ridge Trail for the Arkansas Game \& Fish Commission, Pike County, Arkansas. Report of Investigations No. 133. Archeological \& Environmental Consultants, LLC, Austin.

2012 Archeological and Historical Investigations at the Clear Creek Site (41BW698), Texas A\&M University System, Texas A\&M UniversityTexarkana at Bringle Lake, Bowie County, Texas. Report of Investigations No. 131. Archeological \& Environmental Consultants, LLC, Austin.

2013 Two Middle Caddo Period Habitation Sites and Cemeteries in the Sabine River Basin, Gregg County, Texas. Special Publication No. 27. Friends of Northeast Texas Archaeology, Pittsburg and Austin.

2013 A Late Caddo Cemetery at the A. Davis Site in the Little Cypress Creek Basin, Upshur County, Texas. Journal of Northeast Texas Archaeology 41:1-15.

2013 The Dave Spencer Site on Middle Lilly Creek in Camp County, Texas. Journal of Northeast Texas Archaeology 41:27-29. 
2013 The Mud Creek Site in the Angelina River Basin, Cherokee County, Texas. Journal of Northeast Texas Archaeology 41:31-39.

2013 A Frankston Phase Settlement and Cemetery at the H. C. Slider Site on the Neches River in Cherokee County, Texas. Journal of Northeast Texas Archaeology 41:41-56.

2013 Archeological Survey of Five Proposed Well Pads and Associated Access Roads and Pipelines for Navidad Resources, LLC on the Eastham State Prison Farm, Houston County, Texas. Letter Report No. 306. Archeological \& Environmental Consultants, LLC, Austin.

2014 Additional Caddo Vessels from the Henry Spencer Site (41UR315). Journal of Northeast Texas Archaeology 44:13-16.

2014 A Whole Vessel from the Henry Brown \#2 Site (41HS262), a Historic Nadaco Caddo Site in Harrison County, Texas. Journal of Northeast Texas Archaeology 44:17-19.

2014 The Millsey Williamson (41RK3), Bead Burial, and L. N. Morwell Farm Sites on Martin Creek: Historic Caddo Settlements along Trammels Trace, Rusk County, Texas. Journal of Northeast Texas Archaeology 44:23-46.

2014 Caddo Ceramic Vessels from the Mrs. Martin Farm, Harrison County, Texas. Journal of Northeast Texas Archaeology 44:47-50.

2014 The Clay Ball Site in the Upper Neches River Basin of East Texas. Journal of Northeast Texas Archaeology 44:75-83.

2014 Caddo Ceramic Vessels from the Loftis and Pearl Smith Sites in Harrison County, Texas. Journal of Northeast Texas Archaeology 45:63-66.

2014 Additional Artifact Collections from the Gardener Site (41CP55), Camp County, Texas. Journal of Northeast Texas Archaeology 46:73-79.

2016 Further Surface Collecting and Shovel Testing Investigations at the Sanders Site (41LR2), Lamar County, Texas. Journal of Northeast Texas Archaeology 60:53-64.

2016 A Middle Caddo Period Cemetery (41FK97/139) on Big Cypress Creek in Franklin County, Texas. Journal of Northeast Texas Archaeology 64:1923.

2017 Sherd Assemblages from Sites in Bowie, Cass, Gregg, Lamar, and Red River Counties in East Texas Held by the Sam Noble 
Oklahoma Museum of Natural History. Journal of Northeast Texas Archaeology 76:95-120.

Perttula, T. K. and D. J. Prikryl

1997 Archeological Survey of Pastures 145A and 147E for the Texas Department of Criminal Justice at the Eastham State Prison Farm, Houston County, Texas. Report of Investigations No. 2. Archeological \& Environmental Consultants, LLC, Austin.

Perttula, T. K. and A. F. Ramenofsky

1982 An Archaeological Model of Caddoan Culture Change: The Historic Period. Southeastern Archaeological Conference Bulletin 24:13-15.

Perttula, T. K. and R. Richey

2017 The Robert Richey site in northern Van Zandt County, Texas. Journal of Northeast Texas Archaeology 75:107-110.

Perttula, T. K. and R. A. Ricklis

2005 Archeological Testing at 41 UR77 on Big Sandy Creek, Upshur County, Texas. Archeological Studies Program, Report No. 71. Texas Department of Transportation, Environmental Affairs Division, Austin.

Perttula, T. K. and R. Rogers

2007 The Evolution of a Caddo Community in Northeastern Texas: The Oak Hill Village Site (41RK214), Rusk County, Texas. American Antiquity 72(1):7194.

2012 The Evolution of a Caddo Community in Northeast Texas. In The Archaeology of the Caddo, edited by T. K. Perttula and C. P. Walker, pp. 209-238. University of Nebraska Press, Lincoln.

Perttula, T. K. and R. Z. Selden, Jr.

2011 East Texas Radiocarbon Database. Electronic resource, http://counciloftexasarcheologists.org/?page_id=27, accessed August 2012.

2013 Bibliography on Woodland and Caddo Instrumental Neutron Activation Analysis and Petrographic Studies in East Texas, Northwest Louisiana, eastern Oklahoma, and Southwest Arkansas. Caddo Archeology Journal 23:93-103.

2013 New Radiocarbon Dates from East Texas Caddo Sites. Journal of Northeast Texas Archaeology 40:19-26.

2013 Additional New Radiocarbon Dates from East Texas Caddo Sites. Journal of Northeast Texas Archaeology 42:47-53. 
2014 Glass Beads from Kinsloe Focus Sites in Gregg, Harrison, and Rusk Counties, Texas. Journal of Northeast Texas Archaeology 44:51-73.

2014 Ancestral Caddo Ceramics in East Texas. http://crhrarchaeology.wordpress.com/2014/03/10/ancestral-caddoceramics-in-east-texas-perttula-and-selden/Accessed. March 10, 2014.

2014 Ceramic Sherds from the Morse Mounds Site (41SY27). Center for Regional Heritage Research, Research Report No. 3. Stephen F. Austin State University, Nacogdoches.

2014 New Radiocarbon Dates from East Texas Caddo Sites. Journal of Northeast Texas Archaeology 47:1-8.

2014 New Radiocarbon Dates from the Shelby Mound Site (41CP71) on Greasy Creek in the Big Cypress Creek Basin of East Texas. Journal of Northeast Texas Archaeology 47:31-35.

2014 Ancestral Caddo Ceramics in East Texas. Journal of Northeast Texas Archaeology 48:9-58.

2015 Additional Radiocarbon Dates from East Texas Caddo Sites. Journal of Northeast Texas Archaeology 52:39-41.

2015 Documentation of Caddo Ceramic Vessels in the Texas Parks and Wildlife Department Holdings from Goliad State Park. CRHR Research Reports: Vol. 1 , Article 3. http://scholarworks.sfasu.edu/crhr research reports/vol1/iss $1 / 3$

Perttula, T. K. and H. J. Shafer

2016 Another Look at the Urbankte Site (41CV26) in Coryell County, Texas. Journal of Northeast Texas Archaeology 66:47-50.

Perttula, T. K. and D. L. Sherman

2009 Data Recovery Investigations at the Ear Spool Site (41TT653), Titus County, Texas. Document No. 070205. PBS\&J, Austin.

Perttula, T. K. and J. A. Sitters

2017 Ancestral Caddo Ceramic Vessels from Sites in the Upper Neches River Basin in Anderson and Cherokee Counties, Texas. Journal of Northeast Texas Archaeology 73:1-37.

2017 Ancestral Caddo Ceramic Vessels from Sites in Rusk County, Texas. Journal of Northeast Texas Archaeology 73:45-64. 
2017 Reanalysis of the Ceramic and Lithic Artifacts from the Snipes Site (41CS8) in the Sulphur River Basin of East Texas. The Newsletter of The Friends of the Texas Archeological Research Laboratory (June 2017): 3 , 9.

Perttula, T. K. and B. D. Skiles

1989 Another Look at an Eighteenth Century Archaeological Site in Wood County, Texas. Southwestern Historical Quarterly 92(3):417-435.

2014 The Construction and Eventual Burning of the Experimental Caddo House Structure at the George C. Davis Site (41CE19) in East Texas. Bulletin of the Texas Archeological Society 85:33-47.

2014 The Steck Site (41WD529), a Titus Phase Settlement in the Lake Fork Creek Drainage Basin, Wood County, Texas. Journal of Northeast Texas Archaeology 48:1-8.

2014 Documentation of Late Caddo Period Ceramic Vessels from Sites in the Lake Fork Creek Basin in Wood County, Texas. Journal of Northeast Texas Archaeology 48:59-81.

2016 Ancestral Caddo Ceramic Assemblage from the Spoonbill Site (41WD109) in the Lake Fork Creek Basin, Wood County, Texas. Journal of Northeast Texas Archaeology 70:33-38.

2017 Caddo Ceramic Vessels from the A. C. Gibson Site (41WD1) in the Sabine River Valley, Wood County, Texas. Journal of Northeast Texas Archaeology 73:39-43.

Perttula, T. K. and K. Stingley

2016 Additional Material Culture Remains from the Bowles Creek Site (41CE475) in Cherokee County, Texas. Journal of Northeast Texas Archaeology 67:7-14.

2016 Analysis of the Recovered Artifacts from the Controlled Surface Collection at the Peach Orchard Site (41CE477), Cherokee County, Texas. Journal of Northeast Texas Archaeology 70:91-110.

2017 Continued Shovel Test Investigations at the Historic Caddo Allen Phase Bowles Creek Site (41CE475), Cherokee County, Texas. Journal of Northeast Texas Archaeology 71:105-122.

2017 Test Excavations and Additional Surface Collections at the Peach Orchard Site (41CE477) on Bowles Creek in Cherokee County, Texas. Journal of Northeast Texas Archaeology 73:81-93. 
2017 Archaeological Investigations at the Mike Myers Site (41CE481) on Bowles Creek in Cherokee County, Texas. Journal of Northeast Texas Archaeology 74:47-80.

2017 Ancestral Caddo Ceramic Vessels from East Texas Sites Held by the Gila Pueblo Museum from 1933 to 2017. Journal of Northeast Texas Archaeology 76:1-29.

2017 Archaeological Investigations at the Walnut Branch (41CE47), Ross I (41CE485), and Ross II (41CE486) Sites, Cherokee County, Texas. Journal of Northeast Texas Archaeology 76:31-70.

Perttula, T. K., K. Stingley, and M. Walters

2017 Archaeological Investigations at the Bowles Creek Site (41CE475), Cherokee County, Texas, in Early 2017. Journal of Northeast Texas Archaeology 74:85-95.

Perttula, T. K. and M. Thacker

2014 Analysis of New Artifact Collections from Archaic to Ancestral Caddo Sites in the Saline Creek Basin in Northern Smith County, Texas. Journal of Northeast Texas Archaeology 43:1-25.

2014 Additional Collections of Woodland to Caddo Period Artifacts from the Alligator Pond Site (41SM442), Smith County, Texas. Journal of Northeast Texas Archaeology 46:1-5.

2015 41SM32 on Little Saline Creek in Smith County, Texas. Journal of Northeast Texas Archaeology 55:71-75.

Perttula, T. K. and C. P. Walker

2008 The History of Archaeological Investigations and Geophysical Survey at the Jamestown Mound Site (41SM54), an Archaeological Conservancy Preserve in Smith County, Texas. Archeological \& Environmental Consultants, LLC and Archaeo-Geophysical Associates, LLC, Austin.

Perttula, T. K. and C. P. Walker (editors)

2012 The Archaeology of the Caddo. University of Nebraska Press, Lincoln.

Perttula, T. K. and M. Walters

2006 Texas Archeological Society Academy 101 Field Survey Day, February 19, 2005, Smith County, Texas. Texas Archeological Society, San Antonio.

2012 Caddo Sites in the Saline Creek Basin in Northern Smith County, Texas. Journal of Northeast Texas Archaeology 36:47-63. 
2012 The Killdeer Site (41SM379): A Middle Caddo Site in Northern Smith County, Texas. Journal of Northeast Texas Archaeology 38:31-34.

2015 Woodland and Caddo Period Sites at Toledo Bend Reservoir, Northwest Louisiana and East Texas. Journal of Northeast Texas Archaeology 56:19-124.

2015 Caddo Ceramic Vessels from the Womack Site (41LR1), Lamar County, Texas. Journal of Northeast Texas Archaeology 57:1-12.

2015 Titus Phase Ceramic Vessels from the W. L. Willeford Farm, Upshur County, Texas. Journal of Northeast Texas Archaeology 57:13-30.

2015 Documentation of Ceramic Vessels from an Early Caddo Period Feature at the Boxed Spring Site (41UR30) Site, Upshur County, Texas. Journal of Northeast Texas Archaeology 57:31-43.

2015 Prehistoric Sites in the Sabine River Valley in Northeastern Smith County, Texas. Journal of Northeast Texas Archaeology 57:45-49.

2016 Recent Artifact Surface Collections from the M. S. Roberts (41HE8) Mound Site in the Upper Neches River Basin in East Texas. Journal of Northeast Texas Archaeology 59:69-74.

2016 Caddo Ceramic Vessels from Lake Sam Rayburn Sites. Journal of Northeast Texas Archaeology 61:65-89.

2016 Incised-Punctated Utility Ware Sherds from Lake Sam Rayburn Ancestral Caddo Sites. Journal of Northeast Texas Archaeology 62:1-18.

2016 The Jonas Short Site (41SA101), San Augustine County, Texas. Journal of Northeast Texas Archaeology 62:19-30.

2016 Ceramic Pipes from Lake Sam Rayburn Caddo Sites, Angelina River Basin, East Texas. Journal of Northeast Texas Archaeology 62:37-41.

2016 Bone Tools from Caddo Sites in the Angelina River Basin in East Texas. Journal of Northeast Texas Archaeology 62:43-48.

2016 Possible Engraved Canebrake Rattlesnake Motifs on Sherds from the Etoile Site (41NA11) in the Angelina River Basin in East Texas. Journal of Northeast Texas Archaeology 62:49-50.

2016 The Woodland Period Component at the Wolfshead Site (41SA117), San Augustine County, Texas. Journal of Northeast Texas Archaeology 62:5154. 
2016 Caddo Ceramic Vessels from the S. E. Watson (41RR8) and Hook's Ferry (41RR9) Sites, Red River County, Texas. Journal of Northeast Texas Archaeology 63:39-55.

2016 Caddo Ceramic Vessels from the E. B. Minter (41HP2) and the Roger Attaway (41HP15) Sites in Hopkins County, Texas. Journal of Northeast Texas Archaeology 63:63-73.

2016 Ceramic Vessels from Caddo Sites in Wood County, Texas. Journal of Northeast Texas Archaeology 63:75-131.

2016 Caddo Archaeology in the Caddo Creek Valley of the Upper Neches River Basin, Anderson and Henderson Counties, Texas. Special Publication No. 43. Friends of Northeast Texas Archaeology, Austin and Pittsburg.

2016 Analysis of a Surface Collection of Artifacts from the Battle Mound Site (3LA1), Lafayette County, Arkansas. Field Notes No. 391:3-5 (Newsletter of the Arkansas Archeological Society).

2016 Caddo Ceramic Vessel Sherds in a 2004 Surface Collection from the Sanders Site (41LR2), Lamar County, Texas. Journal of Northeast Texas Archaeology 67:85-88.

2017 Southwestern Pottery Sherd from the Caddo Creek Valley in the Upper Neches River Basin of East Texas. Journal of Northeast Texas Archaeology 71:51-54.

Perttula, T. K. and D. E. Wilson, with contributions by M. Walters

2000 An Early Caddoan Period Cremation from the Boxed Springs Mound Site (41UR30) in Upshur County, Texas, and a Report on Previous Archaeological Investigations. Journal of Northeast Texas Archaeology 12:31-71.

Perttula, T. K. and B. Wishoff

2011 Lake Naconiche Prehistory. Texas Archeology (Newsletter of the Texas Archeological Society) 55(3):11.

Perttula, T. K. and K. Wright

2014 An Engraved Caddo Vessel from the Quitman Area, Wood County, Texas. Journal of Northeast Texas Archaeology 46:69-71.

Perttula, T. K. and W. L. Young

2012 Trends in Archaic and Woodland Period Use of the Middle Sabine River Basin Based on Dart Point Proportions. Journal of Northeast Texas Archaeology 37:23-30. 
Perttula, T. K., J. E. Bruseth, N. A. Kenmotsu, and W. A. Martin

1995 Archeological Testing at the Cabe Mounds (41BW14), Bowie County, Texas. Cultural Resource Management Report 8. Department of Antiquities Protection, Texas Historical Commission, Austin.

Perttula, T. K., J. E. Bruseth, N. A. Kenmotsu, D. J. Prikryl, W. A Martin, L. Banks, J. Smith, N. G. Reese, and S. A. Iruegas

2001 Archeological Investigations on the Red River and Tributaries: Summary of the Findings of the 1991 and 1992 Texas Archeological Society Field School in Red River and Lamar Counties, Texas. Bulletin of the Texas Archeological Society 72:165-250.

Perttula, T. K., L. L. Bush, L. Schniebs, T. Middlebrook, and P. S. Marceaux 2010 An Early Historic Caddo Farmstead at the Henry M. Site (41NA60) in Nacogdoches County, Texas. Stephen F. Austin State University Press, Nacogdoches.

Perttula, T. K., R. Cast, and B. Gonzalez

2008 Caddo Archeology in Texas and the Caddo Nation of Oklahoma: Prospects and Challenges. Caddo Archeology Journal 18:5-10.

Perttula, T. K., R. Cast, B. Gonzalez, and B. Nelson

2009 Documentation of Unassociated and Culturally Unidentifiable Funerary Objects in the U.S. Army Corps of Engineers, Fort Worth District Collections Housed at the Texas Archeological Research Laboratory at the University of Texas at Austin. Special Publication No. 13. Friends of Northeast Texas Archaeology, Pittsburg and Austin.

Perttula, T. K., C. J. Crane, and J. E. Bruseth

1982 A Consideration of Caddoan Subsistence. Southeastern Archaeology 1(2):89-102.

Perttula, T. K., T. E. Emerson, and R. E. Hughes

$200541 \mathrm{HO} 64 / 41 \mathrm{HO} 65$, Late 17th to Early 18th Century Caddo Sites on San Pedro Creek in Houston County, Texas. Bulletin of the Texas Archeological Society 75:85-103.

Perttula, T. K., R. C. Fields, J. E. Corbin, and N. A. Kenmotsu

1993 The Emergence of Sedentism in Northeast Texas, ca. 500 B.C. to A.D. 1000. In Archeology in the Eastern Planning Region, Texas: A Planning Document, edited by N. A, Kenmotsu and T. K. Perttula, pp. 97-120. Cultural Resource Management Report 3. Department of Antiquities Protection, Texas Historical Commission, Austin.

Perttula, T. K., M. F. Hawley, and F. W. Scott 
2002 Caddo Trade Ceramics. Southeastern Archaeology 20(2):154-172.

Perttula, T. K., S. A. Iruegas, and H. Neff

2003 Caddoan Pottery in Central Texas: Geochemical Analyses of Ceramics from Fort Hood and Vicinity. Research Report No. 51. Archeological Resource Management Series, United States Army Fort Hood.

Perttula, T. K., D. B. Kelley, and R. A. Ricklis (assemblers and editors) 2011 Archeological Investigations at the Lang Pasture Site (41AN38) in the Upper Neches River Basin of East Texas. Report No. 129. Texas Department of Transportation, Archeological Studies Program, Environmental Affairs Division, Austin.

Perttula, T. K., D. Lee, and R. Cast

2008 The First People on the Red River: The Caddo People before and after the Freeman-Custis Expedition of 1806. In Freeman and Custis Red River Expedition of 1806: Two Hundred Years Later, edited by L. M. Hardy, pp. 81-110. Bulletin No. 14. Museum of Life Sciences, Louisiana State University in Shreveport.

Perttula, T. K., P. S. Marceaux, and B. Nelson

2012 Study of the Margaret Hinton Collection of Pottery Vessels from Northeast Texas Caddo Cemeteries. Special Publication No. 24. Friends of Northeast Texas Archaeology, Austin and Pittsburg.

Perttula, T. K., P. S. Marceaux, B. Nelson, and M. Walters 2014 Caddo Ceramic Vessels from Sites in the Upper Neches River Basin of East Texas, Anderson and Cherokee Counties, Texas. Special Publication No. 37. Friends of Northeast Texas Archaeology, Pittsburg and Austin.

Perttula, T. K., E. R. Martin, and B. Nelson

1996 Caddo Ceramics on the Red River in North Central Texas. Journal of Northeast Texas Archaeology 8:51-57.

Perttula, T. K., P. McGuff, and C. R. Ferring

1983 Archaeological Research in the McGee Creek Project, Atoka County, Oklahoma. Oklahoma Anthropological Society Newsletter 31(3):3-6.

Perttula, T. K., P. McGuff, C. R. Ferring, and B. C. Yates

1983 McGee Creek Archaeology: A Consideration of Western Ouachita Mountains Prehistory. Bulletin of the Oklahoma Anthropological Society 32:23-54.

Perttula, T. K., A. McKee, M. Walters, and B. Nelson 
2016 New Archaeological Investigations at the M. S. Roberts Site (41HE8) in the Caddo Creek Valley in Henderson County, Texas. Journal of Northeast Texas Archaeology 65:25-51.

Perttula, T. K., M. R. Miller, R. A. Ricklis, D. J. Prikryl, and C. Lintz 1995 Prehistoric and Historic Aboriginal Ceramics in Texas. Bulletin of the Texas Archeological Society 66:175-235.

Perttula, T. K., B. Nelson, and R. Cast

2011 Preliminary Archeological Findings from the Survey of Compartments 1 and 2 at the Little River National Wildlife Refuge, McCurtain County, Oklahoma. Native Heritage Preservation Associates, LLC, Anadarko, Oklahoma.

Perttula, T. K., B. Nelson, R. L. Cast, and B. Gonzalez 2010 The Clements Site (41CS25): A Late $17^{\text {th }}$ to Early $18^{\text {th }}$-Century Nasoni Caddo Settlement and Cemetery. Anthropological Papers No. 92. American Museum of Natural History, New York.

Perttula, T. K., B. Nelson, J. P. Dering, L. A. Schniebs, R. L. Turner, M. Walters, and D. Wilson

2004 Archeological Investigations at the Shelby Site (41CP71) on Greasy Creek, Camp County, Texas. Special Publication No. 5. Friends of Northeast Texas Archaeology, Pittsburg and Austin.

Perttula, T. K., B. Nelson, and B. Gonzalez

1999 Archeological Survey of a Proposed Housing Area Complex in the Walker Creek Project Area for Pilgrim's Pride Corporation, Camp County, Texas. Report of Investigations No. 28. Archeological \& Environmental Consultants, LLC, Austin.

Perttula, T. K., B. Nelson, and P. Haskins 2012 Additional Lake Bob Sandlin Sites with Documented Collections of Prehistoric Lithic and Ceramic Artifacts. Journal of Northeast Texas Archaeology 38:35-44.

Perttula, T. K., B. Nelson, and L. Schniebs

2003 Titus Phase Archeology at the S. Stockade Site (41TT865) on Tankersley Creek, Titus County, Texas. Caddoan Archeology Journal 13(1):7-15.

Perttula, T. K., B. Nelson, and R. Z. Selden, Jr.

2013 Documentation of Cemeteries and Funerary Offerings from Sites in the Upper Neches River Basin, Anderson, Cherokee, and Smith Counties, Texas. Special Publication No. 26. Friends of Northeast Texas Archaeology, Pittsburg and Austin. 
2014 The Gardener Site (41CP55): a Late Caddo Settlement on Big Cypress Creek in East Texas. Journal of Northeast Texas Archaeology 44:1-11.

Perttula, T. K., B. Nelson, R. Z. Selden Jr., and M. Walters

2014 Documentation of Caddo Vessels and Sherds in the Herrington Collection at Tyler Junior College, In Smith County, Texas. Special Publication No. 34. Friends of Northeast Texas Archaeology, Austin and Pittsburg.

2014 Documentation of Ancestral Caddo Ceramic Vessels in the Smith County Historical Museum Collection. Special Publication No. 35. Friends of Northeast Texas Archaeology, Austin and Pittsburg.

Perttula, T. K., B. Nelson, and M. Turner

1996 Initial Report on Archeological Investigations at Lake O' the Pines, a U.S. Army Corps of Engineers-Owned Facility in Northeast Texas. Friends of Northeast Texas Archaeology, Pittsburg and Austin.

Perttula, T. K., B. Nelson, and M. Walters

2000 Archeological Investigations at 41CE299, Double Creek Wastewater Treatment Plant, and along Ragsdale Creek, Cherokee County, Texas. Report of Investigations No. 36. Archeological \& Environmental Consultants, LLC, Austin.

2004 The South Lilly \#4 Site (41UR279), Upshur County, Texas. Journal of Northeast Texas Archaeology 19:22-60.

2008 Archaeological Investigations at the Edwards Creek Site (41FT549) in the Trinity River Basin, Freestone County, Texas. Journal of Northeast Texas Archaeology 27:14-48.

2010 Documentation of Additional Vessels from the Johns Site (41CP12), Camp County, Texas. Journal of Northeast Texas Archaeology 33:93-105.

2011 Archaeological Sites Along King Creek in Western Nacogdoches County, in East Texas. Journal of Northeast Texas Archaeology 34:69-77.

2011 Archeological Survey Investigations to Identify $17^{\text {th }}$-early $19^{\text {th }}$ Century Caddo Sites along El Camino Real de los Tejas National Historic Trail in East Texas. Report of Investigations No. 108. Archeological \& Environmental Consultants, LLC, Austin.

2011 Archeological Survey Investigations of 550 Acres in the Caddo and Mena Ranger Districts of the Ouachita National Forest, Montgomery, Pike, and Polk Counties, Arkansas. Report of Investigations No. 113. Archeological \& Environmental Consultants, LLC, Austin. 
2012 The Buckner Dam Site (41CE339) and Four Other Caddo Sites on Gum Creek in the Upper Neches River Basin, Cherokee County, Texas. Journal of Northeast Texas Archaeology 36:65-75.

2012 Caddo Archaeology at the Henry Spencer Site (41UR315) in the Little Cypress Creek Basin of East Texas. Special Publication No. 20. Friends of Northeast Texas Archaeology, Pittsburg and Austin.

2013 Spatial Patterning of Material Culture Remains and Animal Bone at an Early $18^{\text {th }}$ Century Caddo Site in East Texas. Caddo Archeology Journal 23:105-113.

2013 Archaeological Investigations at the Pine Snake Site, an Allen Phase Settlement on Flat Creek in Northwestern Cherokee County, Texas. Journal of Northeast Texas Archaeology 40:1-18.

2014 Renewed Archaeological Investigations at the Sanders Site (41LR2), Lamar County, Texas. Journal of Northeast Texas Archaeology 47:25-30.

2016 Caddo Ceramic Vessels from the Paul Mitchell Site (41BW4) on the Red River, Bowie County, Texas. Special Publication No. 44. Friends of Northeast Texas Archaeology, Austin and Pittsburg.

20162016 Archaeological Investigations at the Sanders Site (41LR2). CRHR Research Reports, Vol. 2, Article 2. http://scholarworks.sfasu.edu/crhr_research_reports/Vol2/iss1/2.

20172016 Archaeological Investigations at the T. M. Sanders Site (41LR2), Lamar County, Texas. Journal of Northeast Texas Archaeology 72:1-42.

Perttula, T. K., B. Nelson, M. Walters, and C. Kugler

2003 Archeological Investigations at the Lindsay Park Site (41SM300), Smith County, Texas. Report of Investigations No. 62. Archeological \& Environmental Consultants, LLC, Austin.

Perttula, T. K., B. Nelson, M. Walters, and L. Schniebs 2007 Archaeological Investigations of the Lang Pasture (41AN38) Midden Deposits on private property west of the SH 155 Right-of-Way, Anderson County, Texas. Caddo Archeology Journal 16:27-36.

Perttula, T. K., B. Nelson, M. Walters, and R. Z. Selden Jr.

2015 The Sanders Site (41LR2): A Middle to Historic Caddo Settlement and Mound Center on the Red River in Lamar County, Texas. Journal of Northeast Texas Archaeology 50:1-87.

Perttula, T. K., B. Nelson, M. Walters, and R. Cast 
2014 Documentation of Caddo Funerary Objects from the Crenshaw Site (3MI6) in the Gilcrease Museum Collections. Special Publication No. 19. Friends of Northeast Texas Archaeology, Pittsburg and Austin.

Perttula, T. K., B. Nelson, M. Walters, R. Cast, and B. Gonzalez

2009 Documentation of Caddo Funerary Objects in the Gilcrease Museum Collections. Historic Preservation Program, Caddo Nation of Oklahoma, Binger, Oklahoma, and Special Publication No. 12, Friends of Northeast Texas Archaeology, Austin and Pittsburg.

Perttula, T. K., L. Nightengale, and D. H. Jurney

2014 The Distribution of Passenger Pigeon on Caddo Sites in the TransMississippi South. http://crhrarchaeology.wordpress.com/category/transmississippi-south/Posted on line, January 26, 2014.

2014 The Distribution of Passenger Pigeon on Caddo Sites in the TransMississippi South. Journal of Northeast Texas Archaeology 47:37-41.

Perttula, T. K., D. J. Prikryl, B. Nelson, and R. L. Cast

1998 Archeological Survey of the Broken Bow Lake Shoreline and the Relocation and Evaluation of Nine Previously Recorded Sites, McCurtain County, Oklahoma. Report of Investigations No. 7. Archeological and Environmental Consultants, Austin.

Perttula, T. K., D. J. Prikryl, and B. Nelson

1997 Archeological Evaluation of a Proposed Sewer Line in the Knight's Bluff Campground at Atlanta State Park, and Delineation of the Knight's Bluff Site (41CS14) Cemetery/Midden Areas. Texas Archeological Research Laboratory, The University of Texas at Austin.

Perttula, T. K., D. G. Robinson, J. R. Ferguson, and M. D. Glascock

2010 Analysis of Aboriginal Ceramic Sherds. In National Register Testing at 41BQ285, Bosque County, Texas: FM 56 Bridge Replacement at the North Bosque River, by T. B. Griffith, K. W. Kibler, and D. K. Boyd, pp. 85104. Archeological Studies Program, Report No. 101. Environmental Affairs Division, Texas Department of Transportation, Austin.

Perttula, T. K., R. Z. Selden, Jr., and B. Nelson

2013 Analysis of the Ceramic Sherds from Area C at the Ware Acres Site (41GG31), Gregg County, Texas. Journal of Northeast Texas Archaeology 41:57-79.

2014 Documentation of Unassociated Ceramic Vessel Funerary Objects in the Gregg County Historical Museum Collections from Sites in Gregg, Harrison, and Panola Counties in East Texas. Special Publication No. 29. Friends of Northeast Texas Archaeology, Pittsburg and Austin. 
2014 A Catalog of Selected Caddo Ceramic Vessels in the Buddy Jones Collection at the Gregg County Historical Museum. Special Publication No. 30. Friends of Northeast Texas Archaeology, Pittsburg and Austin.

2014 Documentation of Ceramic Vessels and Projectile Points from the C. D. Marsh Site (41HS269) in the Sabine River Basin. Journal of Northeast Texas Archaeology 44:85-98.

2014 Caddo Ceramic Vessels from the Sipes Hill Site (41RK602) along Martin Creek in the Sabine River Basin in East Texas. Journal of Northeast Texas Archaeology 45:9-21.

2014 Archaeological Investigations at the Wade (GC-38) and Estes (GC-49) Sites in the Sabine River Basin, Gregg County, Texas. Journal of Northeast Texas Archaeology 45:39-61.

2014 Documentation of Caddo Vessels in the Robert L. Turner Collection at Stephen F. Austin State University. Special Publication No. 36. Friends of Northeast Texas Archaeology, Pittsburg and Austin.

Perttula, T. K., R. Z. Selden, Jr., and D. Wilson

2014 Corn is Life: Temporal Trends in the Use of Corn (Zea mays) by Caddo Peoples from Radiocarbon-dated Samples and Stable Isotope Analyses. Bulletin of the Texas Archeological Society 85:159-181.

Perttula, T. K., B. D. Skiles, M. B. Collins, M. C. Trachte, and F. Valdez, Jr. 1986 "This Everlasting Sand Bed": Cultural Resources Investigations at the Two Big Sandy Project, Wood and Upshur Counties, Texas. Reports of Investigations No. 52. Prewitt and Associates, Inc., Austin.

Perttula, T. K., B. D. Skiles, and J. A. Sitters

2017 41VN63: A Late Archaic-Woodland Period Site in the Upper Sabine River Basin, Van Zandt County, Texas. Journal of Northeast Texas Archaeology 75:79-82.

Perttula, T. K., B. D. Skiles, and B. C. Yates

1993 The Carlisle Site (41WD46), a Middle Caddoan Occupation on the Sabine River, Wood County, Texas. Notes on Northeast Texas Archaeology 1:3462.

1993 The Goldsmith Site (41WD208): Investigations of the Titus Phase in the Upper Sabine River Basin, Northeast Texas. Bulletin of the Texas Archeological Society 61:139-191.

Perttula, T. K., K. Stingley, and M. Walters 
2016 Historic Caddo Archaeological Sites in Cherokee County, Texas. Journal of Northeast Texas Archaeology 65:1-24.

Perttula, T. K., M. Tate, H. Neff, J. W. Cogswell, M. D. Glascock, E. Skokan, S. Mulholland, R. Rogers, and B. Nelson

1998 Analysis of the Titus Phase Mortuary Assemblage at the Mockingbird Site Kahbakayammaahin" (41TT550). Document No. 970849. Espey, Huston \& Associates, Inc., Austin.

Perttula, T. K., M. B. Trubitt, and J. S. Girard

2012 The Use of Shell-Tempered Pottery in the Caddo Area of the Southeastern United States. Southeastern Archaeology 30(2):242-267.

Perttula, T. K., R. R. Turbeville, and B. D. Skiles

1987 New Thermoluminescence and Radiocarbon Dates from the Upper Sabine River Basin, East Texas. Texas Archeology 31(2):7-9.

Perttula, T. K., M. Turner, and B. Nelson

1997 Radiocarbon and Oxidizable Carbon Ratio Dates from the Camp Joy Mound (41UR144) in Northeast Texas. Caddoan Archeology 7(4):10-16.

1997 A Radiocarbon Date from the Coker Mound (41CS1). Journal of Northeast Texas Archaeology 9:17-20.

Perttula, T. K., C. P. Walker, and T. C. Schultz

2008 A Revolution in Caddo Archaeology: The Remote Sensing and Archaeological View from the Hill Farm Site (41BW169) in Bowie County, Texas. Southeastern Archaeology 27(1):93-107.

Perttula, T. K., M. Walters, R. Cast, B. Gonzalez, and B. Nelson 2007 Documentation of Funerary Offerings from a Prehistoric Caddo Burial at Site 41WD244, Wood County, Texas. Caddo Nation of Oklahoma and Archeological \& Environmental Consultants, LLC, Binger and Austin.

Perttula, T. K., M. Walters, T. H. Guderjan, and P. Haskins $201152^{\text {nd }}$ Caddo Conference and $17^{\text {th }}$ East Texas Archeological Conference, March 2010. Caddo Archeology Journal 21:169-179.

Perttula, T. K., M. Walters, and P. Haskins

2016 The Ceramic Sherd Assemblage from the C. D. Marsh Site (41HS269) in Harrison County, Texas. Journal of Northeast Texas Archaeology 61:5564.

Perttula, T. K., M. Walters, S. Marceaux, and B. Nelson 2009 Caddo Pottery Vessels and Pipes from Sites in the Middle and Upper Sabine and Upper Neches River Basins, Smith and Wood Counties, 
Texas. Special Publication No. 7. Friends of Northeast Texas Archaeology, Pittsburg and Austin.

Perttula, T. K., M. Walters, and B. Nelson

2009 Documentation of the Native American Ceramic Vessels from Northeast Texas, Southern Arkansas, and Eastern Oklahoma in the Boyce Smith Museum in Troup, Texas. Special Publication No. 8. Friends of Northeast Texas Archaeology, Pittsburg and Austin.

2010 Caddo Pottery Vessels and Pipes from Sites in the Big Cypress, Sulphur, Neches-Angelina, and Middle Sabine River Basins in the Turner and Johns Collections, Camp, Cass, Cherokee, Harrison, Morris, Titus, and Upshur Counties, Texas and Sabine Parish, Louisiana. Special Publication No. 10. Friends of Northeast Texas Archaeology, Pittsburg and Austin.

2010 Caddo Pottery Vessels and Pipes from the Johns Site (41CP12) in the Big Cypress Creek Basin in the Turner and Johns Collections, Camp County, Texas. Special Publication No. 11. Friends of Northeast Texas Archaeology, Austin and Pittsburg.

2010 Documenting Caddo Ceramic Sherd and Lithic Collections from Prehistoric Sites at Lake Bob Sandlin. Journal of Northeast Texas Archaeology 33:31-39.

2010 Further Investigations of a Prehistoric Caddo Habitation Site in the White Oak Creek Basin of Northeast Texas: The James Owens Site (41TT769). Caddo Archeology Journal 20:53-76.

2011 Analysis of Artifacts from a 2010 Surface Collection at the Pace McDonald Site (41AN51), A Probable Middle Caddo Mound Center in Anderson County, Texas. Journal of Northeast Texas Archaeology 34:55-66.

2012 Archeological Investigations at the Pace McDonald Site (41AN51): A Middle Caddo Mound Center in the Neches River Basin in East Texas. Special Publication No. 21. Friends of Northeast Texas Archaeology, Pittsburg and Austin.

2012 Early 1960s Excavations at the Sam Kaufman Site (41RR16), Red River County, Texas. Journal of Northeast Texas Archaeology 36:1-31.

2012 The Younger Site (41MR6), Marion County, Texas. Journal of Northeast Texas Archaeology 38:1-20.

2012 Little Cypress Creek Basin Archaeology: Six Late Caddo Period Cemeteries in Upshur County, Texas. Special Publication No. 22. Friends of Northeast Texas Archaeology, Austin and Pittsburg. 
2016 Caddo Ceramic Vessels from the T. M. Sanders Site (41LR2) on the Red River in Lamar County, Texas. Special Publication No. 41. Friends of Northeast Texas Archaeology, Austin and Pittsburg.

2016 Funerary Offerings from the Keasler Site Cemetery (41HS235), Harrison County, Texas. Journal of Northeast Texas Archaeology 63:23-38.

2017 Documentation of Ancestral Caddo Ceramic Vessels and Other Artifacts from East Texas Sites in the George T. Wright Collection at the Sam Noble Oklahoma Museum of Natural History. Special Publication No. 49. Friends of Northeast Texas Archaeology, Austin and Pittsburg.

2017 Documentation of Caddo Vessels from Red River Sites in Bowie and Red River Counties, Texas, in the Collections of the Sam Noble Oklahoma Museum of Natural History. Journal of Northeast Texas Archaeology 76:89-93.

Perttula, T. K., M. Walters, R. J. Nelson, and G. W. Cheatwood

2016 Archaeological Survey Investigations of Private Land within the boundaries of the proposed Lower Bois d'Arc Creek Reservoir Project, Fannin County, Texas. Journal of Northeast Texas Archaeology 66:21-30.

Perttula, T. K., M. Walters, B. Nelson, and A. McKee

2017 The M. S. Roberts Site (41HE8): Archaeological Investigations at a Caddo Mound Site in the Upper Neches River Basin in East Texas. Journal of Northeast Texas Archaeology 71:23-50.

Perttula, T. K., M. Walters, B. Nelson, B. Gonzalez, and R. Cast, with a contribution by R. G. Franciscus

2008 Documentation of Associated and Unassociated Funerary Objects in the Stephen F. Austin State University Collections, Nacogdoches, Texas. Historic Preservation Program, Caddo Nation of Oklahoma. Binger, Oklahoma.

2010 Documentation of Associated and Unassociated Caddo Funerary Objects in the Stephen F. Austin State University Collections, Nacogdoches, Texas. Stephen F. Austin State University Press, Nacogdoches.

Perttula, T. K., M. Walters, K. Stingley, and T. Middlebrook

2017 Ceramic Vessels and Other Funerary Objects in the Titus Phase Cemetery at the Tuck Carpenter Site, Camp County, Texas. Special Publication No. 48. Friends of Northeast Texas Archaeology. Posted on Researchgate, October 2017.

Perttula, T. K., B. Young, and P. S. Marceaux 
2009 Caddo Ceramics from an Early $18^{\text {th }}$ Century Spanish Mission in East Texas: Mission San Jose de los Nasonis (41RK200). Journal of Northeast Texas Archaeology 29:81-89.

Peter, D. E. and C. Stiles-Hanson

1990 An Assessment of the Cultural Resources Within the Longhorn Army Ammunition Plant, Harrison County, Texas. Miscellaneous Report of Investigations No. 3. Geo-Marine, Inc., Plano.

Peter, D. E., M. B. Cliff, and S. M. Hunt

1990 Louisiana Army Ammunition Plant, Cultural Resource Management Plan. Geo-Marine, Inc., Plano.

Peter, D. E., D. E. McGregor, B. C. Yates, G. J. Fritz, and J. E. Bruseth 1988 Site 41DLI48: The Cobb-Pool Site. In Late Holocene Prehistory of the Mountain Creek Drainage, edited by D. E. Peter and D. E. McGregor, pp. 131-198. Joe Pool Lake Archaeological Project, Volume I. Archaeology Research Program, Southern Methodist University, Dallas.

Peterson, D. A.

1985 A Radiocarbon Date from 34Lf-42, the Gertrude Bowman I Site. Oklahoma Anthropological Society Newsletter 33(4):7-8.

1989 A History of Excavations and Interpretations of Artifacts from the Spiro Mounds Site. In The Southeastern Ceremonial Complex: Artifacts and Analysis, edited by P. Galloway, pp. 114-121. University of Nebraska Press, Lincoln.

Peterson, D. A, J. D. Rogers, D. G. Wyckoff, and K. Dohm 1993 An Archeological Survey of the Spiro Vicinity, LeFlore County, Oklahoma. Archeological Resources Survey Report No. 37. Oklahoma Archeological Survey, Norman.

Peukert, J., M. D. Wurtz, M. Huhnke, and D. L. Pemberton

2003 Archeological Impact Evaluations and Surveys in the Atlanta, Tyler, and Lufkin Districts of the Texas Department of Transportation. Special Publication No. 10. Geo-Marine, Inc., Plano.

Peyton, A.

2013 Interim Report: Results of Archaeological Significance Testing at the Sanders Site (41LR2), Lamar County, Texas. SWCA Environmental Consultants, Austin.

Peyton, A. and J. D. Lowe 
2010 Archaeological Monitoring Investigations at Site 41CE19, The Caddo Mounds State Historic Site, Cherokee County, Texas. Cultural Resources Report No. 10-311. SWCA Environmental Consultants, Austin.

Phelps, D. S.

1965 Review of "Engraved Shells from the Craig Mound at Spiro", by L. F. Duffield. American Antiquity 31(2):383-384.

Phillips, P. and J. A. Brown

1978-1984 Pre-Columbian Shell Engravings from the Craig Mound at Spiro, Oklahoma. 6 Vols. Peabody Museum Press, Cambridge.

Picarella, A. E.

1999 The Otter Creek Site (34HS25) and the Fourche Maline Phase of Southeastern Oklahoma. Bulletin of the Oklahoma Anthropological Society 48:1-50.

Pietak, L. M.

2005 Review of "Forest Farmsteads," edited by Ann M. Early with contributions by A. M. Early, R. L. Guendling, R. E. Coleman, and M. L. Williams. Mississippi Archaeology 39(1):73-78.

Pletka, S.

2014 Intensity and Variation in Woodland-Period Radiocarbon Dates from East Texas. Posted on the CRHR: Archaeology website, http://crhrarchaeology.wordpress.com/2014/02/17/intensity-and-variationin-woodland-period-radiocarbon-dates-from-east-texas-pletkal, February 17, 2014.

Pluckhahn, T. J. and M. T. Bonhage-Freund

2010 Archaeological Investigations in Spiro's Hinterlands: Testing of the Lee Creek Ceremonial Site (34SQ12), Sequoyah County, Oklahoma. Memoir 14. Oklahoma Anthropological Society, Norman.

Pluckhahn, T., D. Cranford, and L. Leith

2006 The Ewing Chapel Mound Site, Adair County, Oklahoma. Oklahoma Archeology 54(1):34-40.

Pokrant, M., J. Parrish, T. Florez, S. Hester, Z. Delaune, H. Swife, and A. Montana

2009 Phase I Archeological Investigations at Red River Army Depot and Lone Star Ammunition Plant, Bowie County, Texas. EarthSearch, Inc., New Orleans.

Porter, J. W. 
1971 Thin-Section Identifications of Spiro Sherds. In Spiro Studies, Volume 3: Pottery Vessels, by J. A. Brown, pp. 244-246. First Part of the Third Annual Report of Caddoan Archaeology-Spiro Focus Research. Stovall Museum of Science and History, University of Oklahoma and The University of Oklahoma Research Institute, Norman.

Porter, L.

2010 "New" Radiocarbon Dates for the Petit Jean River Valley: AMS Dates from 3LO226. Field Notes (Newsletter of the Arkansas Archeological Survey) 355:3-4.

Powell, G. S. and N. H. Lopinot

2000 Archeological Plant Remains from the Helm Site. In Data Recovery at the Helm Site, 3HS449, Hot Spring County, Arkansas, by R. H. Lafferty III, A. M. Early, M. C. Sierzchula, M. C. Hill, G. S. Powell, N. H. Lopinot, L. S. Cummings, S. L. Scott, S. K. Nash, and T. K. Perttula, pp. 187-229. MCRA Report 2000-1. Mid-Continental Research Associates, Lowell, Arkansas.

Powell, M. L.

1977 Prehistoric Ritual Skull Burials at the Crenshaw Site (3MI6), Southwest Arkansas. Bulletin of the Texas Archeological Society 48:111-118.

1997 Foreword for Special Papers on Caddoan Bioarcheological Research. Bulletin of the Texas Archeological Society 68:135-138.

1998 Analysis of Burials from the Hood Site. The Arkansas Archeologist 37:6162.

Powell, M. L. and J. D. Rogers

1980 Bioarchaeology of the McCutchan-McLaughlin Site (34Lt-11). Studies in Oklahoma's Past No. 5. Oklahoma Archeological Survey, Norman.

Prewitt, E. R.

2012 Toyah: Reflections on Evolving Perceptions. In The Toyah Phase of Central Texas: late Prehistoric Economic and Social Processes, edited by N. A. Kenmotsu and D. K. Boyd, pp. 181-203. Texas A\&M University Press, College Station.

Prewitt, E. R, J. W. Clark, Jr., and D. S. Dibble

1972 An Assessment of the Archeological and Historical Resources of the Bayou Loco Reservoir Area, Nacogdoches County, Texas. Research Report 11. Texas Archeological Salvage Project, The University of Texas at Austin.

Prewitt, T. J. 
1969 Stylistic Variation in a Caddoan Ceramic Type. Bulletin of the Oklahoma Anthropological Society 17:59-74.

1974 Regional Interaction Networks and the Caddoan Area. Papers in Anthropology 15(2):73-101. Department of Anthropology, University of Oklahoma, Norman.

1974 A Critical Analysis of Caddoan Cultural Units. Master's thesis, Department of Anthropology, University of Oklahoma, Norman.

Prewitt, T. J. and P. Wood

1969 The Sheffield Site: A Fulton Aspect Component in the Short Mountain Reservoir Area. Archaeological Site Report No. 12. Oklahoma River Basin Survey Project, University of Oklahoma, Norman.

Prewitt, T. J., F. Kirby, and D. Gaston

1982 Archaeological Investigations of the Waterfall-Gilford Creeks Watershed, McCurtain County, Oklahoma. Laboratory of Anthropology, University of Tulsa.

Price, G. R. D.

1987 Testing at Archaeological Sites 16NA177, 16NA182, and 16NA236, Natchitoches Parish, Louisiana. Heartfield, Price, and Greene, Inc. Report on file at the Louisiana Division of Archaeology, Department of Culture, Recreation, and Tourism, Baton Rouge.

Prikryl, D. J.

1987 An Appraisal of the Archeological Resources of the Proposed Rockland Lake. U.S. Army Corps of Engineers, Fort Worth District, Fort Worth.

2008 The 1991 and 1992 Texas Archeological Society Field School Excavations at the Fasken Site (41RR14), Red River County, Texas. In Collected Papers from Past Texas Archeological Society Summer Field Schools, edited by T. K. Perttula, pp. 125-171. Special Publication No. 5. Texas Archeological Society, San Antonio.

Prikryl, D. J., K. Gilmore, R. C. Fields, and N. Reese

1984 Archeological and Historical Investigations at 41TT130, Lake Bob Sandlin State Park, Titus County, Texas. Reports of Investigations No. 27. Prewitt and Associates, Inc., Austin.

Proctor, C.

1953 Report on Excavations in the Eufaula Reservoir. Bulletin of the Oklahoma Anthropological Society 1:43-59. 
1957 The Sam Site, Lf-28, of LeFlore County, Oklahoma. Bulletin of the Oklahoma Anthropological Society 5:45-91.

Proctor, R., P. R. Gerrell, M. Prior, and M. B. Cliff

1997 Barksdale Air Force Base: Phase I Cultural Resources Survey of Approximately 5,700 Acres. Geo-Marine, Inc., Plano, Texas.

Purrington, B. L.

1970 The Prehistory of Delaware County Oklahoma: Cultural Continuity and Change on the Western Ozark Periphery. Ph.D. dissertation, Department of Anthropology, University of Wisconsin, Madison.

Raab, L. M.

1977 Archeological Sample Survey of the Caddo Planning Unit, Ouachita National Forest, Arkansas. Archeological Report No. 16. USDA Forest Service, Atlanta.

Rackerby, F.

1980 Certification Program and Society Members Assist at 3LA97 Test Excavations. Arkansas Archeological Society Field Notes 174:7-8.

Ralph, R.

2011 Intensive Archeological Survey of the County Road Northwest-12 ROW, Mount Pleasant, Texas. Archeological Assesments, Manchaca, Texas.

Ray, J. H.

1996 Preservation Measures and Limited Test Excavations at the Pineville Site. Missouri Archaeological Society Quarterly 13(3):12-18.

Ray, J. H. and N. H. Lopinot

2008 Late Prehistoric Culture History for Southwest Missouri. The Missouri Archaeologist 69:57-102.

Ray, J. H. and A. C. Montgomery

2011 A Unqiue Human Effigy Pipe from Cedar County, Missouri. The Missouri Archaeologist 72:161-175.

Ray, M. A.

1960 A Preliminary Report on Excavation at the Pohly Site, My-54. Oklahoma Anthropological Society Newsletter 9:7-10.

1961 A Resurvey of Oklahoma Archaeology (Part I). Oklahoma Anthropological Society Newsletter 9(8):1-7.

1961 A Resurvey of Oklahoma Archaeology (Part II). Oklahoma Anthropological Society Newsletter 9(9):6-11. 
1961 A Resurvey of Oklahoma Archaeology (Part III). Oklahoma Anthropological Society Newsletter 10(2-3):1-16.

1965 A Report on Excavations at the Pohly Site, My-54, in Northeastern Oklahoma. Bulletin of the Oklahoma Anthropological Society 13:1-68.

Raymer, L. E., G. X. Guan, C. V. Voorhies, M. B. Reed, and C. Hanson 1995 An Archaeological Survey of 1,258 Acres and a 3.8 Mile Linear Tract in the Choctaw, Kiamichi, and Teak Districts of the West Zone of Ouachita National Forest, LeFlore and McCurtain Counties, Oklahoma. Technical Report No. 230. New South Associates, Stone Mountain, Georgia.

Raymer, L. E., G. X. Guan, G. I. Williams, M. B. Reed, C. Hanson, and T. M. Hamby

1996 An Archeological Survey of 2019 Acres in the Mena Ranger District of the West Zone of Ouachita National Forest, Scott and Polk Counties, Arkansas. Technical Report 231. New South Associates, Stone Mountain, Georgia.

1997 An Archeological Survey of 8,380 Acres in the Choctaw, Kiamichi, Mena, Oden, Poteau, and Tiak Districts of the West Zone of Ouachita National Forest, Scott, Polk, Yell and Montgomery Counties, Arkansas, and LeFlore and McCurtain Counties, Oklahoma. Technical Report No. 217. New South Associates, Stone Mountain, Georgia.

Reed, H., R. J. Hoard, R. J. Speakman, and M. D. Glascock

2005 A Caddoan-Style Sherd from Marion County, Kansas: Surprising Results from Compositional Analysis. The Kansas Anthropologist 26:1-7.

Reese, N. G. and T. K. Perttula

2001 Archeological and Archival Investigations of the Jonesborough Site (41RR15), Red River County, Texas. Archeological Reports Series No. 2. Texas Historical Commission, Austin.

Rees, M. A.

2004 Phase I Cultural Resources Survey for a Proposed Communications Tower at the Southern Cotton Oil Company Site (16NA14) in Natchitoches, Louisiana. Report on file at the Louisiana Division of Archaeology, Department of Culture, Recreation, and Tourism, Baton Rouge.

2011 The Past that Lies Ahead: Some Recent Developments and Future Directions for Archaeology in Louisiana. Louisiana Archaeology 32:78105.

Rees, M. A. (editor) 
2010 Archaeology of Louisiana. Louisiana State University Press, Baton Rouge.

Rees, J. A., Jr.

2012 The Musicians of Spiro: An Inventory of Sound making Instruments Depicted in the Spiro Shell Engravings. The Arkansas Archeologist 50:2549.

2016 How the Ji'Kmaqn Came to Spiro: Possible additions to the inventory of Sound-making Instruments depicted in the Spiro Engravings. Caddo Archeology Journal 26:43-49.

Reese, M. M.

1931 Report on Work Done on Bruce J. Connally Farm, Franklin County, Texas. MS on file, Texas Archeological Research Laboratory, The University of Texas at Austin.

Reese-Taylor, K.

1993 Petrographic Analysis of Caddo Ceramics from Titus County, Northeast Texas. In Archaeological Investigations within the Monticello B-2 First Five Year Disturbance Area, Titus County, Texas, by S. M. Kotter, R. Rogers, R. Taylor, K. Reese-Taylor, and W. E. Glander, pp. A-1 to A-13. Document No. 920013. Espey, Huston \& Associates, Inc., Austin.

1994 Petrographic Analysis of Caddoan Ceramics from Rusk County, Texas. In National register Testing of Eight Archaeological Sites within the Oak Hill 2,280 Acre Study Area, Rusk County, Texas, by R. Rogers, E. Foster, and K. Reese-Taylor, pp. B-1 to B-15. Document No. 930169. Espey, Huston \& Associates, Inc., Austin.

1995 Evidence of Resource Procurement and Manufacturing Techniques in Caddoan Ceramic Assemblages from the Sabine, Cypress, and Sulphur River Drainage Basins, Rusk and Titus Counties, Texas. Journal of Northeast Texas Archaeology 5:9-27.

1995 Petrographic Analysis of Ceramics. In National Register Testing of Ten Sites in the Monticello B-2 Surface Mine, Titus County, Texas, by M. A. Nash, S. M. Kotter, K. V. Reese-Taylor, E. A. Skokan, E. R. Foster, R. M. Rogers, and W. P. Glander, pp. C-1 to C-13. Document No. 930529. Espey, Huston \& Associates, Inc., Austin.

1997 Petrographic Analysis of Ceramic Thin Sections from 41TT372, Titus County, Texas. In Data Recovery Excavations at Site 41TT372 in the Tankersley Creek Watershed, Monticello B-2 Surface Mine, Titus County, Texas, by E. Barnhart, B. Dixon, S. Kotter, M. Nash, K. Reese-Taylor, E. Skokan, and R. Taylor, Appendix C. Document No. 940608. Espey Huston \& Associates, Inc., Austin. 
Reese-Taylor, K., J. Hageman, and R. A. Ricklis

1995 Preliminary Paste Analysis of Ceramic Samples from the Mustang Branch Site (41HY209) and Barton Site (41HY202). In Archaic and Late Prehistoric Human Ecology in the Middle Onion Creek Valley, Hays County, Texas, by R. A. Ricklis and M. B. Collins, pp. 549-568. 2 Vols. Studies in Archeology 19. Texas Archeological Research Laboratory The University of Texas at Austin.

Regnier, A.

2010 Caddo Conference 2009. Caddo Archeology Journal 20:197-199.

2013 The McDonald Site: An Analysis of WPA Excavations at a Caddo Site in the Glover River Drainage, McCurtain County, Oklahoma. Caddo Archeology Journal 23:27-66.

2014 Report of the $55^{\text {th }}$ Caddo Conference. Caddo Archeology Journal 24:177186.

2017 The Relationship between Becoming Caddo and Becoming Mississippian in the Middle Red River Drainage. In Mississippian Beginnings, edited by G. D. Wilson, pp. 178-202. University of Florida Press, Gainesville.

Regnier, A. L. and R. Fauchier

2009 Archeological Survey of Public Use Lands in the Lower Reach of the Glover River, McCurtain County, Oklahoma. Archeological Resource Survey Report No. 58. Oklahoma Archeological Survey, Norman.

Regnier, A. L., S. W. Hammerstedt, and N. H. Beale

2014 The Grobin Davis Site: Archaeogeophysics and Settlement Patterns at Caddo Mound Centers in Southeastern Oklahoma. Southeastern Archaeology 33(1):87-107.

Regnier, A. L., P. C. Livingood, and S. W. Hammerstedt

2013 The End of the WPA in Oklahoma: The Clement and McDonald Sites. In Shovel Ready: Archaeology and Roosevelt's New Deal for America, edited by B. K. Means, pp. 110-126. University of Alabama Press, Tuscaloosa.

Reynolds, M. D.

2006 Society Members Volunteer at 3CL593. Field Notes (Newsletter of the Arkansas Archeological Society) 329:11.

Reynolds, M. D., with contributions by J. Gaskin, A. Kumar, E. Pope, J. C. Rose, R. J. Scott, M. B. Trubitt, and J. C. Tyler

2007 Preliminary Report on Salvage Excavations at 3CL593. Limited 
distribution report submitted to Arkansas Historic Preservation Program, Little Rock. Arkansas Archeological Survey, Henderson State University Research Station, Arkadelphia.

Richner, J. J.

1982 Tennessee Colony III. Archaeology Research Program, Southern Methodist University, Dallas.

Richner, J. J. and J. T. Bagot (assemblers)

1978 A Reconnaissance Survey of the Trinity River Basin, 1976-1977. Research Report No. 113. Archaeology Research Program, Southern Methodist University, Dallas.

Richner, J. J. and R. Lee

1976 Cultural Resources at Tennessee Colony Lake. Archaeology Research Program, Southern Methodist University, Dallas.

1977 Archaeological and Ethnohistorical Survey at Tennessee Colony Lake, 1975. Research Report No. 104. Archaeology Research Program, Southern Methodist University, Dallas.

Riggs, J.

2000 Ozan \#12 Re-Survey. Natural Resources and Conservation Service, Little Rock.

2000 Ozan \#13 Resurvey. Natural Resources and Conservation Service, Little Rock.

Robinson, D. G.

1997 Cultural Resource Investigations at the Ducks Unlimited Marsh (DUM) Project, North Toledo Bend Reservoir, Shelby County, Texas. Report 973. Cultural Resource Program, Texas Parks and Wildlife Department, Austin.

2012 Petrographic Analysis of Ceramic Sherds from 41SM404. In National Register of Historic Places Eligibility Testing of Site 41SM404 within TxDOT's Tyler District, Smith County, Texas, by M. A. Nash, T. K. Perttula, and L. W. Ellis, pp. E-1 to E-13. Document No. 110055. Atkins, Austin.

2012 Petrographic Analysis. In Archeological Mitigation at the White Oak Shoals Plantation Site (3MI319), Miller County, Arkansas, by A. Stahman, M. Chavez, L. W. Ellis, and M. McWhorther, pp. 72-82. Document No. 110047. Atkins, Austin. 
2013 Ceramic Petrography, Site 41RK375. In NRHP Eligibility Assessment of Sites 41RK322, 41RK375, and 41RK414, Oak Hill Mine, Rusk County, Texas, by D. L. Sherman, L. W. Ellis, B. Harris, M. Nash, and L. Bush, pp. C-1 to C-9. Document No. 120124. Atkins, Austin.

2016 Petrography and Micromorphology of Caddo House Floor Material from 41LR2, Lamar County, Northeast Texas. The Newsletter of The Friends of the Texas Archeological Research Laboratory (December 2016):6.

Robinson, D. G. and T. K. Perttula

2015 Ceramic Petrographic Analysis of Sites 41CP71, 41BW2, 41BW5, and 41SM442, Northeast Texas. Journal of Northeast Texas Archaeology $57: 51-78$.

Robinson, T. H.

1963 Two Caddoan-Like Vessels from the Lower Arkansas River. The Arkansas Archeologist 4(6):14-15.

Roemer, E., Jr. and S. B. Carlson

1987 Excavations at 41BU16: State Highway 21 at the Brazos River, Burleson County, Texas. Contract Reports in Archaeology, Report No. 1. Highway Design Division, Texas State Department of Highways and Public Transportation, Austin.

Rogers, J. D.

1978 Archaeological Site Destruction in the Fourche Maline Valley of Southeastern Oklahoma. Oklahoma Anthropological Society Newsletter 26(8):3-4.

1979 Excavations at Area 7 of the Rock Creek Site (34At-172), Atoka County, Oklahoma. Archaeological Research Report No. 6, Oklahoma Conservation Commission, Oklahoma City.

1979 An Archeological Survey of the Fourche Maline Valley, South of Red Oak, Oklahoma. Archeological Resources Survey Report No. 8. Oklahoma Archeological Survey, Norman.

1981 Spiro Research. Oklahoma Anthropological Society Newsletter 29(3):9-10.

1982 Spiro Archaeology: 1980 Research. Studies in Oklahoma's Past No. 9. Oklahoma Archeological Survey, Norman.

1982 Social Ranking and Change in the Harlan and Spiro Phases of Eastern Oklahoma. Master's thesis, Department of Anthropology, University of Oklahoma, Norman. 
1982 Specialized Buildings in Northern Caddo Prehistory. In Southern Plains Archaeology, edited by S. C. Vehik, pp. 105-117. Papers in Anthropology 23(1). Department of Anthropology, University of Oklahoma, Norman.

1983 Social Ranking and Change in the Harlan and Spiro Phases of Eastern Oklahoma. In Southeastern Natives and Their Pasts, edited by D. G. Wyckoff and J. L. Hofman, pp. 17-128. Studies in Oklahoma's Past No. 11. Oklahoma Archeological Survey, Norman.

1989 Settlement Contexts for Shifting Authority in the Arkansas Basin. In Contributions to Spiro Archaeology: Mound Excavations and Regional Perspectives, edited by J. D. Rogers, D. G. Wyckoff, and D. A. Peterson, pp. 159-176. Studies in Oklahoma's Past No. 16. Oklahoma Archeological Survey, Norman.

1991 A Perspective on Arkansas Basin and Ozark Highland Prehistory. Caddoan Archeology Newsletter 2(1):9-16.

1991 Patterns of Change on the Western Margins of the Southeast, A.D. 600900. In Stability, Transformation, and Variation: The Late Woodland Southeast, edited by M. S. Nassaney and C. R Cobb, pp. 221-248. Plenum Press, New York.

1991 Regional Prehistory and the Spiro Site. Southeastern Archaeology 10:6368.

1995 Dispersed Communities and Integrated Households: A Perspective from Spiro and the Arkansas Basin. In Mississippian Communities and Households, edited by J. D. Rogers and B. D. Smith, pp. 81-98. University of Alabama Press, Tuscaloosa.

1996 Markers of Social Integration: The Development of Centralized Authority in the Spiro Region. In Political Structure and Change in the Prehistoric Southeastern United States, edited by J. F. Scarry, pp. 53-68. University Press of Florida, Gainesville.

2006 Chronology and the Demise of Chiefdoms: Eastern Oklahoma in the Sixteenth and Seventeenth Centuries. Southeastern Archaeology 25(1):20-28.

2009 The Spiro Site. In Archaeology in America: An Encyclopedia, edited by F. P. McManamon, pp. 324-329. Greenwood Press, Westport, Connecticut.

2009 The Harlan Site. In Archaeology in America: An Encyclopedia, edited by F. P. McManamon, pp. 322-323. Greenwood Press, Westport, Connecticut. 
2011 Stable Isotope Analysis and Diet in Eastern Oklahoma. Southeastern Archaeology 30(1):96-107.

Rogers, J. D., D. Heffington, and D. Peterson

1980 Spiro Archaeology: 1979 Excavations. Studies in Oklahoma's Past No. 6. Oklahoma Archeological Survey, Norman.

Rogers, J. D., M. C. Moore, and R. Greaves

1982 Spiro Archaeology: The Plaza. Studies in Oklahoma's Past No. 10. Oklahoma Archeological Survey, Norman.

Rogers, J. D., M. Moore, and J. Stanley

1981 Some Additional Artifacts from Craig Mound. Bulletin of the Oklahoma Anthropological Society 30:33-50.

Rogers, J. D., D. G. Wyckoff, and D. A. Peterson (editors)

1989 Contributions to Spiro Archaeology: Mound Excavations and Regional Perspectives. Studies in Oklahoma's Past No. 16. Oklahoma Archeological Survey, Norman.

Rogers, R.

1995 Archaeological Excavations at Prehistoric Sites 41GM166, 41GM281, and $41 G M 282$ at the Gibbons Creek Lignite Mine, Grimes County, Texas. Document No. 940611. Espey, Huston \& Associates, Inc., Austin.

2000 Excavations at Site 41HP200, Hopkins County, Texas. Document No. 000211. PBS\&J, Austin.

2009 Petrographic Analysis of Ear Spool Site Caddo Ceramics (41TT653). In Data Recovery Investigations at the Ear Spool Site (41TT653), Titus County, Texas, by T. K. Perttula and D. L. Sherman, pp. D-7 to D-10. Document no. 070205. PBS\&J, Austin.

2013 Ceramic Petrography. In Data Recovery at the Hawkwind Site (41HS915), Harrison County, Texas, by L. W. Ellis, R. Rogers, C. Wallace, D. Burden, A. Burden, and C. Heiligenstein, pp. 129-147. Document No. 120087. Atkins, Austin.

Rogers, R. and T. K. Perttula

2004 The Oak Hill Village (41RK214), Rusk County, Texas. Document No. 030083. PBS\&J, Austin.

Rogers, R., M. B. Cliff, T. K. Perttula, G. Rutenberg, S. Victor, P. Dering, and M. Malainey 
2003 Excavations at the Alex Justiss Site, 41TT13, Titus County, Texas. Report No. 36. Archeological Studies Program, Texas Department of Transportation, Austin.

Rogers, R., E. Foster, K. Reese-Taylor, G. Rutenberg, M. Nash, J. Hageman, and D. Jurney

1994 National Register Testing at Eight Archaeological Sites within the Oak Hill 2,280-Acre Study Area, Rusk County, Texas. Document No. 930169. Espey, Huston \& Associates, Inc., Austin.

Rogers, R., M. A. Nash, and T. K. Perttula

2001 Excavations at the Herman Bellew Site (41RK222), Rusk County, Texas. Document No. 000021. PBS\&J, Inc., Austin.

Rohrbaugh, C. L.

1968 The W. H. Baldwin Site, Mc-84. Bulletin of the Oklahoma Anthropological Society 16:95-124.

1971 Hugo Reservoir-1971 Investigations. Oklahoma Anthropological Society Newsletter 19(7):3-5.

1972 Hugo Reservoir \#2. Archaeological Site Report No. 23. Oklahoma River Basin Survey Project, University of Oklahoma, Norman.

1972 New Evidence on the Development of Agriculture in Southeastern Oklahoma. Oklahoma Anthropological Society Newsletter 20(5):2-5.

1973 Hugo Reservoir \#3: A Report on the Early Formative Cultural Manifestations in Hugo Reservoir. Archaeological Site Report No. 24. Oklahoma River Basin Survey Project, University of Oklahoma, Norman.

1974 Radiocarbon Dates from Kaw and Hugo Reservoirs. Oklahoma Anthropological Society Newsletter 22(2):2-8.

1981 Fort Coffee Focus and Spiro Phase: Radiocarbon Dates. Oklahoma Anthropological Society Newsletter 29(5):5-9.

1982 An Hypothesis for the Origins of the Kichai. In Pathways to Plains Prehistory, edited by D. G. Wyckoff and J. L. Hofman, pp. 51-63. Memoir No. 3. Oklahoma Anthropological Society, Norman.

1982 Spiro and Fort Coffee Phases: Changing Cultural Complexes of the Caddoan Area. Ph.D. dissertation, Department of Anthropology, University of Wisconsin, Madison. 
1982 Spiro and Fort Coffee Phase Radiocarbon Dates. Oklahoma Anthropological Society Newsletter 30(9):6-7.

1983 The Varieties of Woodward Plain. In Prairie Archaeology: Papers in Honor of David A. Baerreis, edited by G. E. Gibbon, pp. 29-35. Publications in Anthropology No. 3. University of Minnesota, Minneapolis.

1984 Arkansas Valley Caddoan: Fort Coffee and Neosho Foci. In Prehistory of Oklahoma, edited by R. E. Bell, pp. 265-283. Academic Press, Orlando.

1985 LfGel, the Geren Site, 34Lf36, of the Spiro Phase. Bulletin of the Oklahoma Anthropological Society 34:9-81.

1985 The Subdivision of Spiro Phase. Midcontinental Journal of Archaeology 10:155-170.

1985 Corn from the Geren Site (34LF36). Oklahoma Anthropological Society Newsletter 33(3):3-6.

1987 Radiocarbon Dates from the Geren Site, 34Lf-36. Oklahoma Anthropological Society Newsletter 35(7):9-11.

2012 Spiro and Fort Coffee Phases: Changing Cultural Complexes of the Caddoan Area. Memoir 16. Oklahoma Anthropological Society, Norman.

Rohrbaugh, C. L., R. J. Burton, S. S. Burton, and L. J. Rosewitz 1971 Hugo Reservoir I. Archaeological Site Report No. 22. Oklahoma River Basin Survey Project, University of Oklahoma, Norman.

Rolingson, M. A.

1990 The Toltec Mounds Site: A Ceremonial Center in the Arkansas River Lowland. In The Mississippian Emergence, edited by B. D. Smith, pp. 2749. Smithsonian Institution Press, Washington, D.C.

1998 The Toltec Mounds Site and Plum Bayou Culture: Mound D Excavations. Research Series No. 54. Arkansas Archeological Survey, Fayetteville.

2002 Plum Bayou Culture. Field Notes (Newsletter of the Arkansas Archeological Survey) 309:3-9.

2002 Plum Bayou Culture of the Arkansas-White River Basin. In The Woodland Southeast, edited by D. G. Anderson and R. C. Mainfort, Jr., pp. 44-65. University of Alabama Press, Tuscaloosa. 
2004 Prehistory of the Central Mississippi Valley and Ozarks, after 500 B.C. In Handbook of North American Indians Southeast, Vol. 14, edited by R. D. Fogelson, pp. 534-544. Smithsonian Institution, Washington D.C.

Rolingson, M. A. and J. M. Howard

1997 Igneous Lithics of Central Arkansas: Identification, Sources, and Artifact Distribution. Southeastern Archaeology 16:33-50.

Roper, D. C., J. A. Newkirk, and H. E. Jackson

1985 Testing and Evaluation of the Williams I/ Site (34L25/165).

Gilbert/Commonwealth Inc., Englewood, Colorado.

Rose, D. J., with contributions by T. K. Perttula

2012 A Cultural Resource Inventory of 655 Acres in Bowie County, East Texas. AmaTerra Environmental, Inc., Austin.

Rose, D. and R. Jones

2009 Cultural Resource Inventory of 1,394 Acres at Wright Patman Lake and Lake O' the Pines, Bowie, Camp, Cass, Marion, and Upshur Counties, Texas. Ecological Communications Corporation, Austin.

2010 A Cultural Resource Inventory of 1,722 Acres at Lake O' The Pines and Lake Sam Rayburn, Angelina, Marion, Nacogdoches, Sabine, and San Augustine Counties, Texas. Ecological Communications Corporation, Austin.

Rose, D. J., J. B. Butler, and J. A. Sitters

2015 A Cultural Resource Inventory of 731 Acres at Wright Patman Lake and Sam Rayburn Reservoir. Poznecki-Camarillo, Inc. and AmaTerra Environmental, Inc., San Antonio and Austin.

Rose, J. C.

1984 Bioarchaeology of the Cedar Grove Site. In Cedar Grove: An Interdisciplinary Investigation of a Late Caddo Farmstead in the Red River Valley, edited by N. L. Trubowitz, pp. 227-256. Research Series No. 23. Arkansas Archeological Survey, Fayetteville.

Rose, J. C. (editor)

1999 Bioarcheology of the South Central United States. Research Series 55. Arkansas Archeological Survey, Fayetteville.

Rose, J. C., B. A. Burnett, and A. M. Harmon

1991 Disease and Ecology in the Lower Mississippi Valley and the TransMississippi South. International Journal of Osteoarchaeology 1:241-245.

Rose, J. C., B. A. Burnett, M. S. Nassaney, and M. W. Blauer 
1984 Paleopathology and the Origins of Maize Agriculture in the Lower Mississippi Valley and Caddoan Culture Areas. In Paleopathology at the Origins of Agriculture, edited by M. N. Cohen and G. J. Armelagos, pp. 393-425. Academic Press, New York.

Rose, J. C., P. M. Clancy, and P. H. Moore-Jansen

1981 Bioarcheology of the Roden Site. In Archeological Investigations at the Roden Site (MC-215), McCurtain County, Oklahoma, by G. Perino, pp. 99129. Potsherd Press, Vol. 1. Museum of Red River, Idabel.

Rose, J. C., T. J. Green, and V. D. Green

1996 NAGPRA IS FOREVER: Osteology and the Repatriation of Skeletons. Annual Review in Anthropology 25:81-103.

Rose, J. C., M. P. Hoffman, B. A. Burnett, A. M. Harmon, and J. E. Barnes 1998 Skeletal Biology of the Prehistoric Caddo. In The Native History of the Caddo: Their Place in Southeastern Archeology and Ethnohistory, edited by T. K. Perttula and J. E. Bruseth, pp. 113-126. Studies in Archeology 30. Texas Archeological Research Laboratory The University of Texas at Austin.

Rose, J. C., M. K. Marks, and E. Riddick

1983 Bioarchaeology of the Bug Hill Site. In Bug Hill: Excavation of a Multicomponent Midden Mound in the Jackfork Valley Southeast Oklahoma, by J. H. Altschul, pp. 241-278. Report of Investigation No. 811. New World Research, Inc., Pollock, Louisiana.

Rose, J. C., M. K. Marks, and L. L. Tieszen

1991 Bioarchaeology and Subsistence in the Central and Lower Portions of the Mississippi Valley. In What Mean These Bones? Studies in Southeastern Bioarchaeology, edited by M. L. Powell, P. S. Bridges, and A. M. W. Mires, pp. 7-21. University of Alabama Press, Tuscaloosa.

Rowe, S.

2009 The Akers Site (34LF32): Preliminary Bioarchaeology of a Fourche Maline Site. Master's thesis, Department of Anthropology, University of Oklahoma, Norman.

2014 Wister Area Fourche Maline: A Contested Landscape. Ph.D. dissertation, Department of Anthropology, University of Oklahoma, Norman.

2017 Patterns of Cranial Trauma at the Akers Site (34LF32) of Southeastern Oklahoma. Caddo Archeology Journal 27:20-26.

Rowland, B. 
1993 Cultural Resource Survey Report 08-09-10-340, Womble Ranger District, Ouachita National Forest. Ouachita National Forest, Hot Springs.

Royer, J.

1954 Copper Head from Spiro Mound. Ohio Archaeologist 4(2):30.

Russell, S.

1995 The Legacy of Ethnic Cleansing: Implementation of NAGPRA in Texas. American Indian Culture and Research Journal 19(4):193-211.

Saatkamp, A., J. Brandon, E. Peacock, J. Duff, A. Mitchell, and C. Stanley 2002 A Cultural Resources Survey of Six Proposed Revetment Areas: Finn Phase II, Hurricane, Dickson, Sulphur, and Canale Revetments, Hempstead, Miller and Lafayette Counties, Arkansas, and Cat Island Revetment, Bossier Parish, Louisiana. Panamerican Consultants, Inc., Memphis.

Saatkamp, A. M. Krivor, W. Autin, E. Peacock, and J. Brandon

2001 A Cultural Resources Survey of Four Proposed Revetment Areas: Finn Phase II, Pleasant Valley, Hunters Island, and Black Lake Revetments, Hempstead, Miller, and Lafayette Counties, Arkansas. Panamerican Consultants, Inc., Memphis.

Sabine River Authority of Louisiana and Texas

2012 Toledo Bend Project (FERC No. 2305) Historic Properties Management Plan. Sabine River Authority, State of Louisiana and Sabine River Authority of Texas, Orange, Texas.

Sabo, G. III

1987 Preliminary Excavations at the Huntsville Site: A Caddoan CivicCeremonial Center in Northwest Arkansas. In Contributions to Ozark Prehistory, edited by G. Sabo, III, pp. 55-76. Research Series No. 27. Arkansas Archeological Survey, Fayetteville.

2002 The Rush Creek Phase. Field Notes (Newsletter of the Arkansas Archeological Society) 308:10-14.

2008 Rock Art and the Study of Ancient Religions in Southeastern North America. In Religion, Archaeology, and the Material World, edited by L. Fogelin, pp. 279-296. Occasional Paper No. 36. Center for Archaeological Investigations, Southern Illinois University, Carbondale.

Sabo, G. III (editor)

1987 Contributions to Ozark Prehistory. Research Series No. 27. Arkansas Archeological Survey, Fayetteville. 
Sabo, G. III and D. Sabo (editors)

2005 Rock Art in Arkansas. Popular Series No. 5. Arkansas Archeological Survey, Fayetteville.

Sabo, G. III, A. M. Early, J. C. Rose, B. A. Burnett, J. P. Harcourt, and L. Vogele, Jr.

1988 Human Adaptation in the Ozark-Ouachita Mountains. Research Series No. 31. Arkansas Archeological Survey, Fayetteville.

Sabo, G. III, J. E. Hilliard, and J. J. Lockhart

2012 The Ritual Use of Caves and Rockshelters in Ozark Prehistory. In Sacred Darkness: A Global Perspective on the Ritual Use of Caves, edited by $\mathrm{H}$. Moyes, pp. 237-246. University Press of Colorado, Boulder.

Sabo, G. III, J. J. Lockhart, and J. E. Hillliard

2004 The Forest as Resource: From Prehistory to History in the Arkansas Ozarks. In Upland Oak Ecology Symposium: History, Current Conditions, and Sustainability, edited by M. A. Spetich, pp. 30-35. U.S. Department of Agriculture, Forest Service, Southern Research Station, General Technical Report SRS-73. Ashville, North Carolina.

St. Germain, D. and T. Gannon

1998 An Archeological Survey of 5332 Acres in the Oden, Mena, and Poteau Ranger Districts of the Ouachita National Forest, Montgomery, Polk, Scott and Yell Counties, Arkansas. SPEARS Project Report 124. Spears Professional Environmental and Archeological Research Service, Inc., West Fork, Arkansas.

St. Germain, D., T. Gannon, A. L. Moerbe, and C. S. Spears

1998 An Archeological Survey of 4,421 Acres in the Cold Springs, Caddo, and Jessieville Ranger Districts of the Ouachita National Forest, Garland, Logan, Montgomery, Perry, Saline, and Scott Counties, Arkansas. Project Report 119. Spears Professional Environmental and Archeological Research Service, Inc., West Fork, Arkansas.

St. Germain, D., C. S. Spears, T. Gannon, and D. C. Chenault 1997 An Archeological Survey of 2,036 Acres in the Jessieville, Winona, and Cold Springs Districts of the Ouachita National Forest, Garland, Perry, Saline, and Scott Counties, Arkansas. Project Report 120. Spears Professional Environmental and Archeological Research Service, Inc., West Fork, Arkansas.

Samuelsen, J. R.

2009 Archaeogeophysical Investigations of Early Caddo Settlement Patterning at the Crenshaw Site (3MI6). Master's thesis, Department of Anthropology, University of Arkansas, Fayetteville. 
2010 Geophysical Investigations of Late Fourche Maline and Early Caddo Settlement Patterning at the Crenshaw Site (3MI6). Southeastern Archaeology 29(2):261-278.

2014 AMS and Radiocarbon Dating of the Crenshaw Site (3MI6). The Arkansas Archeologist 52:17-35.

2016 A reanalysis of strontium isotopes from a skull and mandible cemetery at the Crenshaw site: Implications for Caddo interregional warfare. Journal of Archaeological Science: Reports 5:119-134.

Santeford, L. G.

1984 Archeological Testing of the Wilbur Waits Site (34Lf277), Le Flore County, Oklahoma. Department of Anthropology, University of Arkansas, Fayetteville.

1984 Preliminary Archeological Investigations at the PeeWee Site (34LF292), LeFlore County, Oklahoma. Department of Anthropology, University of Arkansas, Fayetteville.

Santeford, L. G. and C. S. Spears

1994 An Archeological Survey of 502 Acres in the Womble District of the Ouachita National Forest, Montgomery County, Arkansas. Project Report 88. Spears Professional Environmental and Archeological Research Service, Inc., West Fork, Arkansas.

1994 An Archeological Survey of 1055 Acres in the Jessieville District and 1578 Acres in the Winona District of the Ouachita National Forest, Montgomery, Yell, Perry, and Saline Counties, Arkansas. Project Report 86. Spears Professional Environmental and Archeological Research Service, Inc., West Fork, Arkansas.

1994 An Archeological Survey of 1130 Acres in the Womble and Cold Springs Districts of the Ouachita National Forest, Montgomery, Scott, and Polk Counties, Arkansas. Project Report 80. Spears Professional Environmental and Archeological Research Service, Inc., West Fork, Arkansas.

1994 An Archeological Survey of 2412 Acres in the Fourche District of the Ouachita National Forest, Yell County, Arkansas. Project Report 85. Spears Professional Environmental and Archeological Research Service, Inc., West Fork, Arkansas.

1994 An Archeological Survey of 190 Acres in the Fourche and Womble Districts of the Ouachita National Forest, Yell and Montgomery Counties, 
Arkansas. Project Report 91. Spears Professional Environmental and Archeological Research Service, Inc., West Fork, Arkansas.

Santeford, L. G., C. S. Spears, and D. Chenault

1994 An Archeological Survey of 440 Acres on Lake Ouachita, Garland and Montgomery Counties, Arkansas. Project Report 84. Spears Professional Environmental and Archeological Research Service, Inc., West Fork, Arkansas.

1995 An Archeological Survey of 3737 Acres in the Jessieville, Caddo, Fourche, Womble, and Winona Ranger Districts, Ouachita National Forest, Yell, Garland, Montgomery, and Perry Counties, Arkansas. Project Report 75. Spears Professional Environmental and Archeological Research Service, Inc., West Fork, Arkansas.

Santeford, L. G., C. S. Spears, D. Chenault, A. L. Moerbe, L. Porter, and V. Galan

1994 An Archeological Survey of 190 Acres in the Fourche and Womble Districts of the Ouachita National Forest, Yell and Montgomery Counties, Arkansas. Ouachita Cultural Resource Report No. 123. Ouachita National Forest, Hot Springs.

Sayles, E. B.

1935 An Archaeological Survey of Texas. Medallion Papers No. 17. Gila Pueblo, Globe, Arizona.

Scarr, K. D.

2008 Trace Element Studies of the Arkansas Novaculite. Master's thesis, Department of Anthropology, University of Arkansas, Fayetteville.

Schambach, F. F.

1970 Pre-Caddoan Cultures in the Trans-Mississippi South: A Beginning Sequence. Ph.D. dissertation, Department of Anthropology, Harvard University, Cambridge.

1970 The Society Dig at Johnny Ford. Fieldnotes (Newsletter of the Arkansas Archeological Society) 69:3-5.

1971 Exploratory Excavations in the Midden Areas at the Crenshaw Site, Miller County, Arkansas. Report submitted to the National Science Foundation in partial fulfillment of NSF Grant No. GS-2684 by the Arkansas Archeological Survey, Fayetteville.

1972 Preliminary Report on the 1972 Excavations at the Ferguson Site (3HE63). The Arkansas Archeologist 13(1-2):1-13. 
1976 An Archeological Survey of Site of Proposed Sewage Treatment Project in the City of Taylor. Project Report No. 124. Arkansas Archeological Survey, Fayetteville.

1979 Summary of Local and Regional Archeology. In Hampton: An Archeological and Historical Overview of a Proposed Strip Mine Tract in South Central Arkansas, edited by T. C. Klinger, pp. 21-30. Research Report 19. Arkansas Archeological Survey, Fayetteville.

1979 The Cultural Setting. In Cultural Resources Survey of Four Proposed Construction Projects along the Red River in Southwestern Arkansas, edited by C. E. Pearson and G. J. DuCote, pp. 3-18. Coastal Environments, Inc., Baton Rouge.

1980 A Preliminary Report on the Ceramics from the 1980 Test Excavations at the Cedar Grove Site, a Caddo V Component in the Great Bend Region in Arkansas. Fieldnotes (Newsletter of the Arkansas Archeological Society) 181:3-9.

1982 The Archeology of the Great Bend Region in Arkansas. In Contributions to the Archeology of the Great Bend Region, edited by F. F. Schambach and F. Rackerby, pp. 1-11. Research Series No. 22. Arkansas Archeological Survey, Fayetteville.

1982 An Outline of Fourche Maline Culture in Southwest Arkansas. In Arkansas Archeology in Review, edited by N. L. Trubowitz and M. D. Jeter, pp. 132197. Research Series No. 15. Arkansas Archeological Survey, Fayetteville.

1988 The Archeology of Oklahoma. The Quarterly Review of Archeology 9(4):59.

1989 The End of the Trail: The Route of Hernando De Soto's Army Through Southwest Arkansas and East Texas. The Arkansas Archeologist 27/28:933.

1990 The "Northern Caddoan Area" was not Caddoan. Caddoan Archeology Newsletter 1(4):2-6.

1990 The Place of Spiro in Southeastern Prehistory: Is It Caddoan or Mississippian. Southeastern Archaeology 9(1):67-69.

1991 Coles Creek Culture and the Trans-Mississippi South. Caddoan Archeology Newsletter 2(3):2-8. 
1991 A Critique of Oklahoma Archeology: With a Reevaluation of the Role of the Spiro Site in Southeastern Prehistory. The Arkansas Archeologist 30:57-69.

1993 Some New Interpretations of Spiroan Culture History. In Archaeology of Eastern North America: Papers in Honor of Stephens Williams, edited by J. B. Stoltman, pp. 187-230. Archaeological Report 25. Mississippi Department of Archives and History Jackson.

1993 Spiroan Entrepots at and Beyond the Western Border of the TransMississippi South. Caddoan Archeology Newsletter 4(2):11-26.

1993 A Summary of the History of the Caddo People. Notes on Northeast Texas Archaeology 2:1-7.

1995 A Probable Spiroan Entrepot in the Red River Valley in Northeast Texas. Caddoan Archeology Newsletter 6(1):9-25.

1995 Investigations of Boone's Mounds (3CA9), Calhoun County, Arkansas. The Arkansas Archeologist 34:61-77.

1996 The Womack, Gilbert and Pearson Sites: Early Eighteenth Century Tunican Entrepots in Northeast Texas? Caddoan Archeology 7(3):9-31.

1996 Mounds, Embankments, and Ceremonialism in the Trans-Mississippi South. In Mounds, Embankments, and Ceremonialism in the Midsouth, edited by R. C. Mainfort and R. Walling, pp. 36-43. Research Series No. 46. Arkansas Archeological Survey, Fayetteville.

1997 Continuing the Discussion of the Spiroans and their Entrepots: A Reply to Brooks' Critique of my New Paradigm for the Archeology of the Arkansas Valley. Caddoan Archeology 7(4):17-46.

1997 The Development of the Burial Mound Tradition in the Caddo Area. Journal of Northeast Texas Archaeology 9:53-72.

1998 Pre-Caddoan Cultures of the Trans-Mississippi South. Research Series 53. Arkansas Archeological Survey, Fayetteville.

1998 The Hood Site in Arkansas Prehistory. The Arkansas Archeologist 37:6374.

1999 Spiro and the Tunica: A New Interpretation of the Role of the Tunica in the Culture History of the Southeast and the Southern Plains, A.D. 1100-1750. In Arkansas Archeology: Essays in Honor of Dan and Phyllis Morse, 
edited by R. C. Mainfort, Jr. and M. D. Jeter, pp. 169-224. University of Arkansas Press, Fayetteville.

1999 Deconstructing the "Sanders Focus" and "Sanders Phase": A Reply to Perttula Regarding the Taxonomy and Significance of the So-Called Sanders Focus, or Sanders Phase Pottery of Northeast Texas and Southeast Oklahoma. Caddoan Archeology 9(3-4):3-55.

2000 The Significance of the Sanders Site in the Culture History of the Mississippi Period Southeast and the Southern Plains. In The 1931 Excavations at the Sanders Site, Lamar County, Texas: Notes on the Fieldwork, Human Osteology, and Ceramics, by A. T. Jackson, M. S. Goldstein, and A. D. Krieger, pp. 1-7. Archival Series 2. Texas Archeological Research Laboratory, The University of Texas at Austin.

2000 Spiroan Traders, the Sanders Site, and the Plains Interaction Sphere: A Reply to Bruseth, Wilson, and Perttula. Plains Anthropologist 45(171):1733.

2001 Fourche Maline and its Neighbors: Observations on an Important Woodland Period Culture of the Trans-Mississippi South. The Arkansas Archeologist 40:21-50.

2001 Fieldwork at Grandview. Field Notes (Newsletter of the Arkansas Archeological Society) 299:7-8.

2001 A Preliminary Report on the 2001 Investigations of the Arkansas Archeological Survey and the Arkansas Archeological Society at the Grandview Prairie Wildlife Management Area, Hempstead County, Southwest Arkansas. Field Notes (Newsletter of the Arkansas Archeological Society) 301:5-11

2002 Preliminary Plans for the 2002 Field Training Program. Field Notes (Newsletter of the Arkansas Archeological Society) 305:6-7.

2002 The Grandview Archeological Project: The Arkansas Archeological Survey/Arkansas Archeological Society's 2002 Field Season at the Grandview Prairie Wildlife Management Area, Columbus, Arkansas. Field Notes (Newsletter of the Arkansas Archeological Society) 308:3-8.

2002 Radiocarbon Dates from the 2001 Arkansas Archeological Survey/Archeological Society Excavations at the Tom Jones Site (3HE40). Field Notes (Newsletter of the Arkansas Archeological Society) 309:13. 
2002 Fourche Maline: A Woodland Period Culture of the Trans-Mississippi South. In The Woodland Southeast, edited by D. G. Anderson and R. C. Mainfort, Jr., pp. 91-112. University of Alabama Press, Tuscaloosa.

2003 Osage Orange Bows, Indian Horses, and the Blackland Prairie of Northeastern Texas. In Blackland Prairies of the Gulf Coastal Plain: Nature, Culture, and Sustainability, edited by E. Peacock and T. Schauwecker, pp. 212-236. University of Alabama Press, Tuscaloosa.

2003 Plans for the June 2003 Training Program, Grandview Wildlife Management Area. Field Notes (Newsletter of the Arkansas Archeological Society) 311:6-8.

2003 Some Highlights of the June 7-22, 2003 Fieldwork at the Grandview Prairie Wildlife Management Area. Field Notes (Newsletter of the Arkansas Archeological Society) 315:3-9.

2003 Archeological Phases in the Felsenthal Region, Southcentral Arkansas, Part I: The Caney Bayou Phase. Field Notes (Newsletter of the Arkansas Archeological Society) 312:9-14

2004 First Report on Spring Fieldwork at Grandview. Field Notes (Newsletter of the Arkansas Archeological Society) 318:14.

2014 Introduction to the Crenshaw Bioanthropological Project. The Arkansas Archeologist 52:1-15.

Schambach, F. F., A. M. Early, E. T. Hemmings, D. B. Kelley, and M. Swanda 1982 Southwest Arkansas. In A State Plan for the Conservation of Archeological Resources in Arkansas, edited by H. A. Davis. Research Series No. 21. Arkansas Archeological Survey, Fayetteville.

Schambach, F. F. and J. E. Miller

1984 A Description and Analysis of the Ceramics. In Cedar Grove: An Interdisciplinary Investigation of a Late Caddo Farmstead in the Red River Valley, edited by N. L. Trubowitz, pp. 109-170. Research Series No. 23. Arkansas Archeological Survey, Fayetteville.

Schambach, F. F., N. L. Trubowitz, F. Rackerby, E. T. Hemmings, W. F. Limp, and J. E. Miller III

1982 Test Excavations at the Cedar Grove Site (3LA97): A Late Caddo Farmstead in the Great Bend Region, Southwest Arkansas. In Contributions to the Archeology of the Great Bend Region, edited by F. F. Schambach and F. Rackerby, pp. 90-127. Research Series No. 22. Arkansas Archeological Survey, Fayetteville. 
Schambach, F. F., M. Zabecki, D. G. Akridge, and J. Samuelsen 2011 Determining the Cultural Affiliation of Detached Crania and Mandibles at the Crenshaw Site, Miller County, Arkansas. Arkansas Archeological Survey, Fayetteville.

Schambach, F. F. and F. Rackerby (editors)

1982 Contributions to the Archeology of the Great Bend Region. Research Series No. 22. Arkansas Archeological Survey, Fayetteville.

Schleidt-Peñalva, M. L., D. Turpin, and R. Waldon

2007 Heritage Resource Survey for Upper Cossatot Watershed (Compartments 920-923, 937-941, 943, 944), Mena Ranger District, Polk County, Arkansas. Ouachita Cultural Resource Report No. 284. USDA Forest Service, Ouachita National Forest, Hot Springs, Arkansas.

Schleidt-Peñalva, M. L., G. Stepp, A. Strothers, D. Turpin, and R. Waldon 2009 Heritage Resource Survey for Two Mile Watershed (Compartments 906, 923-930, 950, 952, 982, \& 983) Mena Ranger District, Polk County, Arkansas. Ouachita Cultural Resource Report No. 302. USDA Forest Service, Ouachita National Forest, Hot Springs, Arkansas.

Schneider, E., J. Holland, M. Chancellor, C. Lintz, and T. Stone, with contributions by T. N. Trierweiler, R. Holmes, and R. Nichols.

1998 Integrated Cultural Resource Management Plan for Red River Army Depot, Texas, 1999-2003 (with Programmatic Agreement). TRC Mariah Associates, Inc., Austin.

Schneider, F. E.

1966 Oklahoma River Basin Survey Excavations. Oklahoma Anthropological Society Newsletter 14(8):6-7.

Schneider, F. and D. G. Wyckoff

1967 Eight Archaeological Sites in the Webber's Falls Lock and Dam Area, Oklahoma. Archaeological Site Report No. 7. Oklahoma River Basin Survey Project, University of Oklahoma Research Institute, Norman.

Schniebs, L.

2001 Griffin Mound Site (41UR142) Faunal Analyses. Journal of Northeast Texas Archaeology 14:13-30.

2014 Analysis of the Hardin A Site (41GG69) Faunal Remains. Journal of Northeast Texas Archaeology 47:9-15.

2014 Analysis of the Faunal Remains from the Musgano Site (41RK19), A Caddo Site in Rusk County, Texas. In The Caddo Archaeology of the Musgano Site (41RK19) in the Sabine River Basin of East Texas, by T. K. Perttula, pp. 41-44. Special Publication No. 28. Friends of Northeast 
Texas Archaeology, Pittsburg and Austin.

Schniebs, L. and T. K. Perttula

2014 Analysis of Faunal Remains from Selected Contexts at the Shelby Mound Site (41CP71): Results from Mound Excavations. Journal of Northeast Texas Archaeology 46:57-62.

Scholtz, J. A.

1963 Test Excavations at the Powell Site (3CL9): A Temple Mound Site in Southwest-Central Arkansas. The Arkansas Archeologist 4(10):1-2.

1965 Test Excavations at the Dillard Mound (3CL25), a Gibson Aspect Caddoan Site in Clark County, Southwest Arkansas, and Analysis of Surface Collections from Sites along the Interstate Highway System in Arkansas. Highway Salvage Archaeological Program, Phase 1, Pt. 1. University of Arkansas Museum, Fayetteville.

1966 Dillard Mound and Powell Mound Sites. In Caddoan Area Field Reports, 1962-1964 Field Seasons, edited by H. A. Davis, pp. 19-21. University of Arkansas Museum, Fayetteville.

1969 A Summary of Prehistory in Northwest Arkansas. The Arkansas Archeologist 10(1-3):50-60.

1970 Bayou Sel: A Salt Works in Southwest Arkansas. Arkansas Archeological Society Field Notes 65:5-6.

1974 Archeological Investigations in the Gillham Reservoir Area, Southwest Arkansas, Aug-Sept 1967. University of Arkansas Museum, Fayetteville.

1986 Preliminary Testing at the Powell Site, 3CL9: A Temple Mound Site in Clark County, Arkansas. The Arkansas Archeologist 23/24:11-42.

Scholtz, J. A. and H. A. Davis

1967 A Compilation of Arkansas C14 Dates. University of Arkansas Museum, Fayetteville, Arkansas.

Scholtz, S. C.

1975 Prehistoric Plies: A Structural and Comparative Analysis of Cordage, Netting, Basketry, and Fabric from Ozark Bluff Shelters. Research Series No. 9. Arkansas Archeological Survey, Fayetteville.

Schroeder, E. A.

1997 Limited Testing at the Turbeville Site (41WD382), Wood County, Texas. Journal of Northeast Texas Archaeology 9:42-52. 
Schultz, T. C.

2010 Architectural Variability in the Caddo Area of Eastern Texas. Ph.D. dissertation, Department of Anthropology, The University of Texas at Austin.

2010 Architectural Variability in the Caddo Area of Eastern Texas. Special Publication No. 16. Friends of Northeast Texas Archaeology, Pittsburg and Austin.

Scott, S. L. and H. E. Jackson

1998 Early Caddo Ritual and Patterns of Animal Use: An Analysis of the Faunal Remains from the Crenshaw Site (3MI6), Southwestern Arkansas. The Arkansas Archeologist 37:1-37.

Scott, T. R., M. McCarthy, and M. A. Grady

1978 Archaeological Survey in Cherokee, Smith, and Rusk Counties, Texas: A Lesson in Survey Methods. Research Report No. 116. Archaeology Research Program, Southern Methodist University, Dallas.

Scurlock, J. D.

1962 The Culpepper Site, a Late Fulton Aspect Site in Northeast Texas. Bulletin of the Texas Archeological Society 32:285-316.

1964 Archeological Reconnaissance at Toledo Bend Reservoir, 1962-1963 Season. Texas Archeological Salvage Project, The University of Texas at Austin.

1965 The Kadohadacho Indians: A Correlation of Archaeological and Documentary Data. Master's thesis, Department of Anthropology, The University of Texas at Austin.

Scurlock, J. D. and W. A. Davis

1962 Appraisal of the Archeological Resources of Toledo Bend Reservoir, Pinola, Newton, Sabine, and Shelby Counties, Texas; Sabine and DeSoto Parishes, Louisiana. Texas Archeological Salvage Project, The University of Texas at Austin.

Selden, R. Z., Jr.

2010 Toward a Unique Understanding of Washington Square: Digitization and Spatial Representation of a Caddo Mound Site. Master of Interdisciplinary Studies, Stephen F. Austin State University, Nacogdoches.

2011 Digital Preservation and Spatial Representation at the Washington Square Mound Site (41NA49), Nacogdoches County, Texas. Caddo Archeology Journal 21:129-145. 
2012 Modeling Regional Radiocarbon Trends: A Case Study from the East Texas Woodland Period. Radiocarbon 54(2):239-265.

2013 Consilience: Radiocarbon, Instrumental Neutron Activation Analysis and Litigation in the Ancestral Caddo Region. Ph.D. dissertation, Department of Anthropology, Texas A\&M University, College Station.

2013 Toward an Actualistic Petrofacies Model for the Angelina River Basin in East Texas. Council of Texas Archeologists 37(2):30-53.

2013 Exploratory 3D Documentation and a Preliminary Geometric Morphometric Analysis of NAGPRA Vessels from the Washington Square Mound Site (41NA49), Nacogdoches County, Texas. Reports in Archaeology No. 1. Center for Regional Heritage Research. Stephen F. Austin State University, Nacogdoches.

2013 Geometric Morphometrics of Caddo Ceramics. SAA Current Research Online 162. Electronic document, http://www.saa.org/Current Research/pdf/saa cro 162 Geometric Morphometrics o.pdf.

2013 Preliminary Comparative 3D Geometric Morphometrics of Caddo Jars from the Washington Square Mound, Vanderpool, and McSpadden Sites. http://crhrarchaeology.wordpress.com/2013/11/18/preliminarycomparative-3d-geometric-morphometrics-of-caddo-jars-from-thewashington-square-mound-vanderpool-and-mcspadden-sites-selden/

2014 Exploratory 3D Documentation and a Preliminary Geometric Morphometric Analysis of NAGPRA Vessels from the Vanderpool Site (41SM77), Smith County, Texas. Reports in Archaeology No. 2. Center for Regional Heritage Research. Stephen F. Austin State University, Nacogdoches.

2014 Temporal Dynamics of East Texas Caddo Sites with Nine or Fewer Radiocarbon Dates. Journal of Northeast Texas Archaeology 43:64-71.

2014 Instrumental Neutron Activation Analysis in the Ancestral Caddo Territory. Caddo Archeology Journal 24:75-86.

2014 Caddo Ceramic Vessels from the McSpadden Site. Journal of Northeast Texas Archaeology 47:91-95.

2014 Preliminary 3D Morphometrics of the Wesley Ellis Collection. http://crhrarchaeology.wordpress.com/2014/11/03/preliminary-3dmorphometrics-of-the-wesley-ellis-collection/

2015 3D Scan Data of Caddo Burial Vessels from the McSpadden Site near Frankston, Texas. CRHR Research Reports 1(5). 
2016 3D Scan Data for Caddo Ceramic Vessels from the George C. Davis Site (41CE19). Journal of Texas Archaeology and History, 2016, Data Paper Series 1:1-8.

2016 3D Scan Data for Caddo Ceramic Vessels from 41WD60 in the Texas Parks and Wildlife Collections. Journal of Texas Archaeology and History, 2016, Data Paper Series 1:9-13.

2016 3D Scanning at the Texas Archeological Research Laboratory. The Newsletter of The Friends of the Texas Archeological Research Laboratory (December 2016):3.

Selden, R. Z., Jr. and T. K. Perttula

2013 Radiocarbon Trends and the East Texas Caddo Tradition (ca. A.D. 8001680). Southeastern Archaeology 32(1):85-96.

2013 Temporal Dynamics of East Texas Caddo Sites with 10 or More Radiocarbon Dates. Journal of Northeast Texas Archaeology 41:81-99.

2014 Concerning the U.S. Forest Service Collections in East Texas. http://crhrarchaeology.wordpress.com/2014/04/14/concerning-the-usforest-service-collections-in-east-texas-selden-and-perttula/

2014 At the Confluence of GIS and Geochemistry: Identifying Geochemical Correlates of Ripley Engraved Caddo Ceramics. Bulletin of the Texas Archeological Society 85:147-158.

Selden, R. Z. Jr., B. K. Means, J. C. Lohse, C. Koenig, and S. L. Black 2014 Beyond Documentation: 3D Data in Archaeology. Texas Archeology (Newsletter of the Texas Archeological Society) 58(4):20-24.

Selden, R. Z., Jr., T. K. Perttula, and D. L. Carlson

2014 INAA and the Provenance of Shell-Tempered Sherds in the Ancestral Caddo Region. Journal of Archaeological Science 47:113-120.

Selden, R. Z., Jr., T. K. Perttula, S. L. Eckert, and D. L. Carlson 2014 Regarding Caddo INAA. http://crhrarchaeology.wordpress.com/2014/03/31/regarding-caddo-inaaselden-perttula-eckert-and-carlson/

Selden, R. Z., Jr., T. K. Perttula, and M. J. O'Brien

2014 Advances in Documentation, Digital Curation, Virtual Exhibition, and a Test of 3D Geometric Morphometrics: A Case Study of the Vanderpool Vessels from the Ancestral Caddo Territory. Advances in Archaeological Practice 2(2):64-79. 
Shaeffer, J. B.

1956 Salvage Archaeology. Oklahoma Anthropological Society Newsletter $5(5): 4-5$.

1958 The Horton Site, a Fultonoid Village Near Vian, Oklahoma. Bulletin of the Oklahoma Anthropological Society 6:126.

1960 Salvage Archaeology in Oklahoma, Vol. I. Archives of Archaeology No. 9. University of Wisconsin Press, Madison, Wisconsin.

1965 Salvage Archaeology in Oklahoma, Vol. I. Papers of the Oklahoma Archaeological Salvage Project Nos. 8-15. Bulletin of the Oklahoma Anthropological Society 13:77-151.

1966 Salvage Archaeology in Oklahoma, Vol. II. Papers of the Oklahoma Archaeological Salvage Project Numbers 18-21. Bulletin of the Oklahoma Anthropological Society 14:1-86.

Shafer, H. J.

1966 Archeological Survey of Honea, Pat Mayse, and Halsell Reservoirs, Texas. Survey Report No. 1. Texas Archeological Salvage Project, The University of Tom at Austin.

1973 Lithic Technology at the George C. Davis Site, Cherokee County, Texas. Ph.D. dissertation, Department of Anthropology, The University of Texas at Austin.

1974 Lithic Reduction Strategies at the George C. Davis Site. Louisiana Archaeology 1:66-74.

1975 Comments on Woodland Cultures of East Texas. Bulletin of the Texas Archeological Society 46:249-254.

1981 Archeological Investigations at the Attaway Site, Henderson County, Texas. Bulletin of the Texas Archeological Society 52:147-179.

2007 Leaning Rock Site (41SM325) Lithics. Caddo Archeology Journal 16:5770.

2007 People of the Prairie: A Possible Connection to the Davis Site Caddo. Research module published on-line by the Council of Texas Archeologists, Prairiecaddomodule.pdf.

2008 A Study of Chipped Stone Artifacts from the Redwine Site (41SM193), Smith County, Texas. Journal of Northeast Texas Archaeology 27:49-75. 
2011 Lithic Technology at the George C. Davis Site, Cherokee County, Texas. Special Publication No. 18. Friends of Northeast Texas Archaeology, Austin and Pittsburg.

2011 Boxed Springs Mound Site (41UR30) Lithic Analysis. In Archaeological and Archaeogeophysical Investigations at an Early Caddo Mound Center in the Sabine River Basin of East Texas, assembled by T. K. Perttula, pp. 78-111. Special Publication No. 15. Friends of Northeast Texas Archaeology, Austin and Pittsburg.

2011 Comparing the Boxed Springs Lithics to Other Early Caddo Sites. In Archaeological and Archaeogeophysical Investigations at an Early Caddo Mound Center in the Sabine River Basin of East Texas, assembled by T. K. Perttula, pp. 112-137. Special Publication No. 15. Friends of Northeast Texas Archaeology, Austin and Pittsburg.

2011 Dee Ann Story. Texas Archeology (Newsletter of the Texas Archeological Society) 55(2):12-13, 15.

2011 The Legacy of Dee Ann Story: Highlights and Caddo Archaeology at the George C. Davis Site. Newsletter of the Southern Texas Archaeological Association 37(1):3.

2013 Miscellaneous Notes and Remembrances: Starting an Archaeological Career in Central Texas. La Tierra 39:39-52.

Shafer, H. J. and L. Green

2008 Tuinier Borrow Pit Biface Cache, Hopkins County, Texas. Caddo Archeology Journal 18:26-39.

Shafer, H. J. and T. R. Hester

2014 The Legacy of Dee Ann Story. Bulletin of the Texas Archeological Society 85:9-30.

Shafer, H. J. and M. Walters

2010 The Browning Site (41SM195A) Lithics: Considering Patterns of Identity and Interaction through Lithic Analysis. Bulletin of the Texas Archeological Society $81: 127-151$.

Shafer, H. J., M. Walters, and D. L. Carlson

2012 The Bateman Biface Cache (41SM443). Bulletin of the Texas Archeological Society 83:129-144.

Shaffer, B. S. 
2000 Analysis of the Vertebrate Faunal Remains from the Fredericks Site. Louisiana Archaeology 24:93-106.

Shah, S., M. Reynolds, A. Pappas, J. O'Donnell, and M. Creswell

2011 Section 110 Survey of 690 Acres at the DeGray Reservoir, Hot Springs and Clark Counties, Arkansas. Cultural Resources Investigations Technical Report 7, Volume 2. Brockington and Associates, Norcoss, Georgia.

Sharrock, F. W.

1960 The Wann Site, Lf-27, of the Fourche Maline Focus. Bulletin of the Oklahoma Anthropological Society 8:17-47.

Shea, A. B.

1980 Analysis of Plant Remains from the Hanna Site. Louisiana Archaeology 5:269-281.

Shead, R. R.

1951 Engraved Shell of the Spiro Mound. Seventh Annual Report of the University of Oklahoma 1950:17-41. University of Oklahoma, Norman.

Shelton, R.

2012 Pedestrian Survey of the Mineola Lake in Mineola Nature Preserve, Wood County, Texas. Cultural Resources Report 2012-22. AR Consultants, Inc., Richardson.

Shelton, R., C. S. Davis, C. Turley, and S. A. Skinner (editors)

2011 Archaeological Investigations at the Woodbury Creek Site, Rains County, Texas. AR Consultants, Inc., Dallas.

Sherman, D. L.

1997 East Texas Electric Cooperative, Inc. Cultural Resources Survey (Kennedy Sullivan-Ben Wheeler, Ben Wheeler-Starr, Starr-E. Burgess Segments), Van Zandt County, Texas. Document No. 970140. Espey, Huston \& Associates, Inc., Austin.

2001 NRHP Eligibility Testing (41RK107, 41RK240, 41RK242, 41RK243, 41RK276, and 41RK286) and Additional Testing (41RK243) Investigations within the Oak Hill DIII Mine, Permit No. 46, Rusk County, Texas. Document No. 000237. PBS\&J, Austin.

2016 National Register Testing at 41CP183, a Small Middle Caddo Settlement, Camp County, Texas. Blanton \& Associates, Inc., Austin.

Sherman, D. L. and S. Victor 
2001 National Register of Historic Places Eligibility Assessment of Site 41RK270, 41RK272, 41RK275, and 41RK284, Rusk County, Texas. Document 000400. PBS\&J, Austin.

Sherman, D. L., T. Blakistone, F. King, and T. K. Perttula 2004 Phase I Cultural Resources Survey of the Proposed TXU Mining Leesburg First 5-Year Mine Area, Camp County, Texas. Document No. 030357. PBS\&J, Austin.

Sherman, D. L., P. Dering, and T. K. Perttula

2004 National Register Testing of Site 41CP408: A Middle Caddoan Farmstead, Camp County, Texas. Document No. 040031. PBS\&J, Austin.

Sherman, D. L., L. W. Ellis, C. Heligenstein, S. Laurence, R. Rogers, H. Rush, J. Shipp, and C. Wallace

2011 National Register of Historic Places Eligibility Testing on Three Prehistoric Sites (41CP28, 41CP88 and 41CP414) Within the Leesburg Mine, Camp County, Texas. Document NO. 100105. PBS\&J, Austin.

Sherman, D. L., L. W. Ellis, B. Harris, M. Nash, and L. Bush

2013 NRHP Eligibility Assessment of Sites 41RK322, 41RK375, and 41RK414, Oak Hill Mine, Rusk County, Texas. Document No. 120124. Atkins, Austin.

Sherman, D. L., M. T. Iruegas, M. Nash, and S. Victor

2002 NRHP Eligibility Testing Investigations on Sites 41RK247, 41RK248, and 41RK379, Extended Testing on Site 41RK247, Historic Component II, and Shovel Testing on Site 41RK331 Within the Oak Hill D-III Mine, Permit No. 46, Rusk County, Texas. Document No. 020286. PBS\&J, Austin.

Sherman, D. L., M. A. Nash, T. K. Perttula, G. S. Greene, E. A. S. Switek, and R. M. Rogers

1998 National Register Testing of Five Cultural Resources Sites in the Oak Hill D-III Permit Area, Rusk County, Texas. Document No. 971091. Espey, Huston \& Associates, Inc., Austin.

Sherman, D., R. Clark, B. Harris, A. McWhorter, L. W. Ellis, C. Wallace, H. Rush, R. Shortes, and R. Rowe

2012 Cultural Resource Survey of the Proposed Liberty Deposit Mine Area, Rusk County, Texas. Document No. 100196. Atkins, Austin.

Sherrod, P. C. and M. A. Rolingson

1987 Surveyors of the Ancient Mississippi Valley. Research Series No. 28. Arkansas Archeological Survey, Fayetteville.

Shiner, J. L.

1980 Lithic Technology in Northeast Texas. Louisiana Archaeology 6:241-248. 
Shortes, C. R., S. L. Fischbeck, and L. W. Ellis

2012 National Register of Historic Places Eligibility Testing on Three Prehistoric Sites (41CP393, 41CP420, and 41CP447) within the Leesburg Mine, Camp County, Texas. Document No. 110153. Atkins, Austin.

Sierzchula, M. C.

2001 Phase I Cultural Resource Survey of Two Locations in Grant County, Arkansas, for the Southwest Water Users Association. MCRA Report 2001-6. Mid-Continental Research Associates, Inc., Lowell, Arkansas.

Sierzchula, M. C., and R. H. Lafferty, III

1999 Phase I Cultural Resources Survey of Proposed Water Treatment Facility for the City of Malvern, Arkansas. MCRA Report 99-02. Mid-Continental Research Associates, Inc., Lowell, Arkansas.

2002 Archeological Survey and Monitoring of Irrigation Trench Excavations: The Sugar Creek Golf Course Development, Benton County, Arkansas. MCRA Report 2001-7. Mid-Continental Research Associates, Inc., Lowell, Arkansas.

2003 Phase I Archeological Survey of 220 Acres for the City of Russellville Proposed Industrial Park, Pope County, Arkansas. MCRA Report 2003-7. Mid-Continental Research Associates, Inc., Lowell, Arkansas.

2004 Phase I Archeological Survey Carroll Electric Rudd to Purdy Line, Carroll and Madison Counties, Arkansas. MCRA Report 2004-5. Mid-Continental Research Associates, Inc., Lowell, Arkansas.

Sierzchula, M. C., R. Lafferty III, and K. M. Hess

2003 A Cultural Resource Survey of Select Areas in Highfill, Arkansas for the Proposed Osage Basin Wastewater System. MCRA Report 2003-5. MidContinental Research Associates, Inc., Lowell, Arkansas.

2003 A Cultural Resource Survey of Select Areas in Tontitown, Arkansas, for the Proposed Osage Basin Wastewater System. MCRA Report 2003-4. Mid-Continental Research Associates, Inc., Lowell, Arkansas.

2004 A Cultural Resource Survey of Osage Basin Wastewater System, Outfall Lines and Treatment Facility, Benton and Washington Counties, Arkansas. MCRA Report 2004-2. Mid-Continental Research Associates, Inc., Lowell, Arkansas.

Sierzchula, M. C., M. J. Guccione, R. H. Lafferty III, and M. T. Oates 
1995 Archeological Investigations in the Great Bend Region, Miller County, Arkansas, Levee Items 2 and 3. Report 94-5. Mid-Continental Research Associates, Inc., Springdale, Arkansas.

Sievert, A. K.

1992 The Craig Mound at Spiro, Oklahoma. Artifacts from the Collection of the Smithsonian Institution, Summary Report. Report to the Department of Anthropology and Office of Repatriation, Smithsonian Institution, Washington, D.C.

1994 The Detection of Ritual Tool Use through Functional Analysis: Comparative Examples from the Spiro and Angel Sites. Lithic Technology 19(2):146-156.

2003 Spiro painted maces and shell cups: The scientific use of artifacts without context. In Theory, Method, and Practice in Modern Archaeology, edited by R. L. Jeske and D. K. Charles, pp. 182-194. Praeger, Westport, Connecticut.

Sievert, A. K. and J. D. Rogers, with contributions by J. Urcid 2011 Artifacts from the Craig Mound at Spiro, Oklahoma. Smithsonian Contributions to Anthropology, Volume 49. Smithsonian Institution, Washington, D.C.

Sills, E. and M. B. Cliff

2003 Results of National Register Investigations Conducted on Sites 41TT440 and 41TT486, Titus County, Texas. Document No. 020294. PBS\&J, Dallas.

Simpson, D. B.

2002 A Hybrid Classification Technique for Predicting Cultural Anomalies in a Set of Geophysical Data from the Black Hoe Site, 3BE536, Benton County, Arkansas. Master's Thesis, Department of Anthropology, University of Arkansas, Fayetteville.

Sitters, J. A. and H. Bentley

2017 CRM Survey of East Texas Lakes. CTA Newsletter 41(2):16-22.

Sitters, J. A. and T. K. Perttula

2017 Another Look at the Snipes Site (41CS8) on the Sulphur River, Cass

County, Texas. Journal of Northeast Texas Archaeology 75:53-72.

Sitters, J. A., D. Rose, and J. B. Butler

2016 An Archaeological Resource Survey of 953 Acres at Wright Patman Lake, Bowie and Cass Counties, Texas. Poznecki-Camarillo, Inc. and AmaTerra Environmental, Inc., San Antonio and Austin. 
Sitters, J. A., M. D. Miller, E. Schroeder, and R. Feit

2015 Interim Report for National Register of Historic Places Eligibility Testing of Sites 41 TT876 and 41TT103, Titus County, Texas. AmaTerra Environmental, Inc., and Texas Department of Transportation, Austin.

Skiles, B. D., J. E. Bruseth, and T. K. Perttula

1980 A Synthesis of the Upper Sabine River Basin Culture History. The Record 36:1-12. Dallas Archeological Society, Dallas.

Skinner, S. A.

1970 Ethnographic Analogy and Caddoan Prehistory. Student Anthropologist 2(2):60-67. Southern Methodist University, Dallas.

1971 Archaeological Reconnaissance of Ponta Reservoir, Texas. Department of Anthropology, Southern Methodist University, Dallas.

1980 Preadaptation for the Southern Cult in the Caddoan Heartland. Louisiana Archaeology 6:207-221.

1984 Cultural Resources Survey of the Lake Fork Raw Water Transmission Line. Cultural Resources Report 84-6. AR Consultants, Inc., Dallas.

1999 Cultural Resources Survey of Tram Island and Compartment 6 at Sam Rayburn Lake, Texas. Cultural Resources Report 99-37. AR Consultants, Inc., Dallas.

2000 Archaeological Survey of the Gateway Power Plant Project, Upshur County, Texas. Cultural Resources Report 2000-5. AR Consultants, Inc., Dallas.

2000 Cultural Resources Survey of the Mount Pleasant Golf Course Expansion. Cultural Resources Report 2000-19. AR Consultants, Inc., Dallas.

2001 Archaeological Survey of the Longview Site, Gregg County, Texas. Cultural Resources Report 2001-19. AR Consultants, Inc., Dallas.

2001 On the Divide between Sanders and Pine Creeks, an Archaeological Survey of the B \& B Landfill Site, Lamar County, Texas. Cultural Resources Report 2001-35. AR Consultants, Inc., Dallas.

2002 Archaeological Survey of Sandy Creek Lake, Henderson County, Texas. Cultural Resources Report 2002-36. AR Consultants, Inc., Dallas.

2005 Survey and Excavation at the 2005 Field School. Texas Archeology 49(2):1, 3-4. 
2007 An Update on the Gene and Ruth Ann Stallings Site \& A Plea for Your Help. Texas Archeology 51(1):13.

Skinner, S. A. (editor)

1981 Cultural Resources Survey of the Troup Mine, Texas. Cultural Resources Program Investigative Report 81-7. Environmental Consultants, Inc., Dallas.

Skinner, S. A. and L. Baird

1984 Supplemental Cultural Resources Survey for Expansion Areas of the Troup Mine Block, Texas. Cultural Resources Report 84-10. AR Consultants, Inc., Dallas.

Skinner, S. A. and F. D. Kent

2000 Archaeological Survey of the Lake Fork Pipeline, Wood to Hunt Counties, Texas. Cultural Resources Report 2000-32. AR Consultants, Inc., Dallas.

2000 Archaeological Reconnaissance in Eastern Wood County, Texas. Cultural Resources Report 2000-35. AR Consultants, Inc., Dallas.

Skinner, S. A. and L. K. Trask

1996 An Archeological Evaluation of the Mosquito Island Site, Sam Rayburn Lake, Texas. Cultural Resources Report 96-12. AR Consultants, Inc., Dallas.

Skinner, S. A. and B. B. Whorton

1993 Cultural Resources Survey of the Proposed Atlanta City Park. Cultural Resources Report 93-15. AR Consultants, Inc., Dallas.

Skinner, S. A., C. B. Bousman, N. Plumb, A. P. Wilson, J. Todd, and T. A. Jennings

2005 Archaeology and Quaternary Geology at Lake Ralph Hall, Fannin County, Texas. Cultural Resources Report 2005-31, AR Consultants, Inc., Dallas.

Skinner, S. A., C. S. Davis, and R. Shelton

2010 Research Design for the Proposed Lower Bois d'Arc Creek Reservoir Project, Fannin County, Texas. Cultural Resources Report 2005-31. AR Consultants, Inc., Dallas.

Skinner, S. A., R. K. Harris, and K. M. Anderson (editors)

1969 Archaeological Investigations at the Sam Kaufman Site, Red River County, Texas. Contributions in Anthropology No. 5. Department of Anthropology, Southern Methodist University, Dallas.

Skinner, S. A., J. Todd, T. Jennings, and M. Dennis 
2004 Archaeological Survey at the Greenwood Farms Landfill, Smith County, Texas. Cultural Resources Report 2004-2. AR Consultants, Inc., Dallas.

Skinner, S. A., C. B. Whitley, C. S. Davis, W. W. Crook, III, and M. D. Hughston 2014 An Engraved Slate Gorget from the Upper Rockwall Site (41RW2), Rockwall County, Texas. Archeological Journal of the Texas PrairieSavannah 4:68-75.

Skokan, E. and T. K. Perttula

1998 The Petrographic Analysis of Ceramic Thin-Sections from the Mockingbird Site (41TT550), Titus County, Texas. In Analysis of the Titus Phase Mortuary Assemblage at the Mockingbird or "Kahbakayammaahin" Site (41TT550), by T. K. Perttula, M. Tate, H. Neff, J. W. Cogswell, M. D. Glascock, E. Skokan, S. Mulholland, R. Rogers, and B. Nelson, pp. 273288. Document No. 970849. Espey, Huston \& Associates, Inc., Austin.

Skokan-Switek, E.

1997 Results of the Petrographic Analysis of Ceramics from Site 41RK342, Rusk County, Texas. In Cultural Resources Investigations of the Oak Hill D-III Permit Area, Rusk County, Texas, by E. A. Skokan, E. Foster, and R. Rogers, Appendix E. Document No. 940002. Espey, Huston \& Associates, Inc., Austin.

1997 Results of the Petrographic Analysis of Ceramics from Sites 41TT572, 41TT577, 41TT591, 41TT593, and 41TT653, Titus County, Texas. In National Register Testing of Seven Sites in the Monticello B-2 Surface Mine, Titus County, Texas, by V. Galan, R. Rogers, T. K. Perttula, and E. S. Switek, Appendix C. Document No. 971085. Espey, Huston \& Associates, Inc., Austin.

2004 Petrographic Analysis of Ceramics. In The Oak Hill Village Site (41RK214), Rusk County, Texas, by R. Rogers and T. K. Perttula, pp. 295-306. Document No. 930083. PBS\&J, Austin.

Skokan, E. A, E. Foster, and R. Rogers

1997 Cultural Resources Investigations of the Oak Hill D-III Permit Area, Rusk County, Texas. Document No. 940002. Espey, Huston \& Associates, Inc., Austin.

Skrla, A. L.

2011 Unlocking Ancient Diet: Using Starch Garnules in Food Residue from Cooking Ceramics to Analyze Pre-Columbian Era Caddo Diet. Senior Scholars Thesis, Office of Undergraduate Research, Texas A\&M University, College Station.

Smart, R. J. 
2007 Phase I Cultural Resource Survey of the Cypress Bend Development, Bossier Parish, Louisiana. TAS, Inc., Canyon Lake, Texas.

Smith, A.L. and L. C. Stewart-Abernathy

2003 A Survey of Portions of the Lake Dardanelle Shoreline, Pope and Johnson Counties, Arkansas. ARPA Permit No. DACWO3-9-96-1172. Arkansas Archeological Society, Russellville.

Smith, B. D.

1984 Mississippian Expansion: Tracing the Historical Development of an Explanatory Model. Southeastern Archaeology 3:13-32.

Smith, B. W.

1975 Prehistoric Settlement Patterns of the Young's Bayou Drainage, Natchitoches Parish, Louisiana. Louisiana Archaeology 2:163-200.

Smith, G. P.

2001 Cultural Resource Work on 1289 Acres at DeGray Lake, Clark and Hot Spring Counties, Arkansas. Cultural Resource Services, Inc., Memphis.

2001 Cultural Resource Work on 740 Acres at Lake Greeson, Pike County, Arkansas. Cultural Resource Services, Inc., Memphis.

2002 Cultural Resource Work on 510 Acres on Lake Ouachita in Montgomery County, Arkansas. Cultural Resource Services, Inc., Memphis.

Smith, G. P. and J. W. Matthews

2000 Cultural Resource Work on 869 Acres on Lake Greeson, Pike County, Arkansas. Cultural Resources Services, Inc., Memphis.

Smith, G. P., and N. C. Smith

1999 Cultural Resource Work on 395 Acres in Garland and Montgomery Counties on Lake Ouachita, Arkansas. Cultural Resource Services, Inc., Memphis.

2000 Cultural Resources Work on 430 Acres on Lake Ouachita in Garland and Montgomery Counties, Arkansas. Cultural Resource Services, Inc., Memphis.

2003 Cultural Resource Work on 78 Acres on Lake Ouachita in Garland County, Arkansas. Cultural Resources Services, Inc., Memphis.

2003 Cultural Resource Work on 1551 Acres on DeGray Lake, Clark and Hot Spring Counties, Arkansas. Cultural Resources Services, Inc., Memphis.

Smith, J. E., II 
1996 The Rodeo Hill and Third Dam Sites: Two Ceramic-Bearing Sites in Somervell County, Texas. The Cache: Collected Papers on Texas Archeology 3:67-75. Office of the State Archeologist, Texas Historical Commission, Austin.

Smith, M., B. Harris, and D. Burden

2013 Intensive Archeological Survey for the North East Texas Regional Mobility Authority Proposed Toll 49, Segment 3B Between Interstate Highway 20 and State Highway 31, Tyler, Smith County, Texas. Document No. 100106. Atkins North America, Inc., Austin.

Smith, M., B. Harris, D. Burden, and M. B. Cliff

2010 Intensive Archeological Survey for the North East Texas Regional Mobility Authority Proposed Toll 49, Segment 4B Between Interstate Highway 20 and State Highway 3, Smith County, Texas. PBS\&J, Dallas.

Smith, R. L.

2008 Vertebrate Faunal Identifications from Carden Bottom (3YE347), Arkansas. The Arkansas Archeologist 45:7-20.

Smith, S. D., P. G. River, K. M. Byrd, and N. W. Hawkins

1983 Louisiana's Comprehensive Archaeological Plan. Louisiana Division of Archaeology, Baton Rouge.

Soltysiak, K. and T. Scott

2010 Cultural Resources Desktop Analyses and GIS Modeling for the Toledo Bend Relicensing Project in Texas and Louisiana. HRA Gray \& Pape, LLC, Houston.

Soltysiak, K., T. Scott, and T. D. Goggin

2011 Management Summary: Cultural Resources Field Investigations for the Toledo Bend Relicensing Project in Texas. HRA Gray \& Paper, LLC, Houston.

Speakman, J. and T. K. Perttula

2003 Results of the Instrumental Neutron Activation Analysis of Caddo Ceramic Sherds from the Hatchel Site. In Archeological Investigations of Village Areas at the Hatchel Site (41BW3), Bowie County, Texas, by T. K. Perttula and B. Nelson, pp. 161-166. Report of Investigations No. 58. Archeological and Environmental Consultants, LLC, Austin.

Spears, C. S.

1984 An Archeological Survey of the Lower Lee Creek Water Supply Crawford County, Arkansas, and Sequoyah County, Oklahoma. Project Report No. 571. Arkansas Archeological Survey, Fayetteville. 
1989 Cultural Resources Assessment of the Proposed Primary and Alternate Pipeline Routes, Arkansas. In Environmental Assessment of Proposed NOARK Pipeline. Report 89-8. Spears Professional Environmental and Archeological Research Service, Inc., West Fork, Arkansas.

1989 An Archeological Survey of 663Acres in the Caddo Ranger District of the Ouachita National Forest, Garland and Montgomery Counties, Arkansas. Report No. 89-3. Spears Professional Environmental and Archeological Research Service, Inc., West Fork, Arkansas.

1992 A Cultural Resources Assessment of the Proposed Lake Acilla on the North Fork of the Saline River, Saline County Arkansas. Project Report 54. Spears Professional Environmental and Archeological Research Service, Inc., West Fork, Arkansas.

1999 Archeological Survey of 10,000 Feet of Proposed Sewer Lines at DeGray Lake, Clark County, Arkansas. Project Report 136. Spears Professional Environmental and Archeological Research Service, West Fork, Arkansas.

2001 Cultural Resources Survey and Testing at Sites 3GA117 and 3GA785 on USDA Forest Service Property for Proposed Waterlines in Western Garland County, Arkansas. Project Report 144. Spears Professional Environmental \& Archeological Research Services, Inc., West Fork, Arkansas.

2002 An Archeological Survey of 45 Acres Proposed for Residential Development on Clabber Creek, Washington County, Arkansas. Project Report 154. Spears Professional Environmental and Archeological Research Service, Inc., West Fork, Arkansas.

2002 An Archeological Survey of a Proposed Timber Access Road in the Mena District of the Ouachita National Forest, Polk County, Arkansas. Spears Professional Environmental and Archeological Research Service, Inc., West Fork, Arkansas.

2003 An Archeological Survey of the Proposed Genova Power Facility Project, Benton and Washington Counties, Arkansas. Project Report 149. Spears Professional Environmental and Archeological Research Service, Inc., West Fork, Arkansas.

Spears, C. S. and C. Branam

2007 A Cultural Resources Survey of the Proposed River Ridge Development and Testing at Site 3PI565 on the Little Missouri River, Pike County, Arkansas. Project Report 177. Spears Professional Environmental and Archeological Research Services, Inc., West Fork, Arkansas. 
Spears, C. S. and T. N. Gannon

2002 Cultural Resources Survey and Monitoring of Water System Improvements Through Historic Clear Springs, Clark County, Arkansas. Project Report 134. Spears Professional Environmental and Archeological Research Service, Inc., West Fork, Arkansas.

Spears, C. S. and C. A. Johnson

1999 An Archeological Survey of 1,267 Acres on the DeGray Lake, Clark and Hot Spring Counties, Arkansas. Project Report 137. Spears Professional Environmental and Archeological Research Service, Inc., West Fork, Arkansas.

Spears, C. S. and A. Moerbe

1998 An Archeological Survey of the Proposed Interstate 71 from Texarkana to the Louisiana State Line, Miller County. Spears Professional Environmental and Archeological Research Service, Inc., West Fork, Arkansas.

Spears, C. S., D. C. Chenault, L. G. Santeford, and A. L. Moerbe 1994 An Archeological Survey of 301 Acres in the Cold Springs District of the Ouachita National Forest, Scott County, Arkansas. Ouachita Cultural Resource Report 107. Ouachita National Forest, Hot Springs.

1994 An Archeological Survey of 210 Acres in Compartment 1683, Womble District of the Ouachita National Forest, Montgomery County, Arkansas. Ouachita Cultural Resource Report 108. Ouachita National Forest, Hot Springs.

Spears, C. S., D. C. Chenault, and A. L. Moerbe 1997 Limited Archeological Investigations of Cultural Resources within the Mena Airport Expansion Project, Polk County, Arkansas. Project Report 108. Spears Professional Environmental and Archeological Research Service, Inc., West Fork, Arkansas.

Spears, C. S., A. L. Moerbe, and C. Catlin

2000 Significance Testing of Three Sites (3MI324, 3MI329, and 3M/330) near the Northern Loop of the Proposed Interstate 71, Texarkana, Arkansas. Project Report 112. Spears Professional Environmental and Archeological Research Service, West Fork, Arkansas.

Spears, C. S., L. G. Santeford, M. A. Hughes, and D. S. Chenault 1993 An Archeological Survey of 1,077 Acres on the Jessieville District of the Ouachita National Forest, Yell and Perry Counties, Arkansas. Ouachita Cultural Resource Report 101. Ouachita National Forest, Hot Springs. 
1993 An Archeological Survey of 623 Acres on the Caddo District, Ouachita National Forest, Montgomery County, Arkansas. Ouachita Cultural Resource Report 99. Ouachita National Forest, Hot Springs.

1993 An Archeological Survey of 356 Acres in the Caddo District of the Ouachita National Forest, Montgomery County, Arkansas. Ouachita Cultural Resource Report 100. Ouachita National Forest, Hot Springs.

Spears, C. S., L. G. Santeford, M. P. Hoffman, and A. L. Moerbe

1994 Part I and II: A Cultural Resources Assessment of Proposed Interstate 71 Corridors Between Texarkana and Louisiana, Miller County, Arkansas. Project Report 71. Spears Professional Environmental and Archeological Research Service, Inc., West Fork, Arkansas.

Spears, C. S., K. L. Smith, K. Hoffman, M. Hughes, A. Moerbe, and M. Bartlett 1993 A Cultural Resources Survey of 2260 Acres in the Cold Springs, Fourche, and Caddo Ranger Districts of the Ouachita National Forest, Garland, Logan, Scott, and Yell Counties, Arkansas. Project Report 62. Spears Professional Environmental and Archeological Research Service, Inc., West Fork, Arkansas.

Spears, C. S., R. A. Taylor, K. L. Smith, and E. M. Morris 1988 Ouachita National Forest: Archeological Survey and Predictive Model Evaluation. Report No. 88-1. Spears Professional Environmental \& Archeological Research Service, West Fork, Arkansas.

Spencer, A. C.

2010 Phase I Cultural Resources Inventory of the Red Bayou Watershed Project, Caddo Parish, Louisiana. USDA, Natural Resources Conservation Service. Report on file, Louisiana Division of Archaeology, Baton Rouge.

Spivey, T. and D. G. Wyckoff

1983 A T-shaped Stone Pipe from Marshall County, Oklahoma. Oklahoma Anthropological Society Newsletter 31(7):3-5.

Spock, C.

1977 An Analysis of the Architectural and Related Features at the George C. Davis Site. Master's thesis, Department of Anthropology, The University of Texas at Austin.

Stahman, A., M. Chavez, L. W. Ellis, and A. McWhorter 2013 Archeological Mitigation At The White Oak Shoals Plantation Site (3MI319), Miller County, Arkansas. Document No. 110047. Atkins, Austin.

Stambaugh, M. C., J. Sparks, R. P. Guyette, and G. Wilson 
2011 Fire History of a Relict Oak Woodland in Northeast Texas. Rangeland Ecology \& Management 64(4):419-423.

Stanfill, A. G.

1977 An Archeological Investigation of Seven Ground Disturbing Projects in the Oden District of the Ouachita National Forest. Ouachita National Forest, Hot Springs.

Stanyard, W.

2006 Phase I Cultural Resource Investigations for the Centerpoint Energy Gas Transmission Company, Carthage to Perryville Project, Panola County, Texas Segment. TRC, Austin.

Stanyard, W. and L. Thomas

2010 Phase I Cultural Resource Investigations for the CenterPoint Energy Field Services Magnolia II Project Semp Russ Plantation, 6H-1 Natural Gas Pipeline, Natchitoches Parish, Louisiana. TRC, Austin.

Stanyard, W. F., L. Thomas, B. Thomas, and R. Keenoy

2006 Phase I and II Cultural Resource Investigations for the Centerpoint Energy Gas Transmission Company Carthage to Perryville Project: Louisiana Segment. TRV, Atlanta, Georgia.

Stappenbeck, S. C.

1986 A Systematic Approach to the Analysis of Ceramic Collections from San Augustine County, Texas. Master's thesis, Department of Anthropology, The University of Texas at Austin.

Starr, J. D.

2017 The Adair Site: Caddo Relations through Ceramic Analysis. Caddo Archeology Journal 27:27-35.

Starr, M. E., B. R. Collins, A. E. Helms, and C. H. McNutt, Jr.

1996 A Cultural Resource Survey of 1996 Timber Sale Tracts at DeGray Lake and Lake Greeson in Clark, Pike, and Hot Spring Counties, Arkansas. Garrow \& Associates, Inc., Memphis.

Steed, R.

2006 Some observations on Caddoan archaeology in Arkansas. The Amateur Archaeologist 12(1):59-66.

Steele, G. D.

1971 An Interesting Find from Northeastern Oklahoma. Oklahoma Anthropological Society Newsletter 19(2):11.

Stephenson, R. L. 
1948 Archeological Survey of McGee Bend Reservoir: A Preliminary Report. Bulletin of the Texas Archeological and Paleontological Society 19:57-73.

1970 Archeological Investigations in the Whitney Reservoir Area, Central Texas. Bulletin of the Texas Archeological Society 41:37-276.

1996 Stansbury Site. In The New Handbook of Texas, Vol. 6, edited by R. Tyler, p. 59. Texas State Historical Association, Austin.

Steponaitis, V. P., M. J. Blackman, and H. Neff

1996 Large-Scale Patterns in the Chemical Composition of Mississippian Pottery. American Antiquity 61(4):555-572.

Stepp, G.

2005 Cultural Resource Survey Report 08-09-07-497 Timber Harvest Surveys in Mena Ranger District, Ouachita National Forest. Ouachita National Forest, Hot Springs.

Stewart, J. H.

1994 Archeological Investigations at Sites 3SC980 and 3SC981 Within the Ouachita National Forest, Scott County, Arkansas. Project 924. Arkansas Archeological Survey, Fayetteville.

1995 Archeological Investigations in the Southern Ouachita Mountains: Excavations at the Shady Lake Recreation Area and Vicinity. Project Report No. 856. Arkansas Archeological Survey, Fayetteville.

Stingley, K. and T. K. Perttula

2017 The Garden Site (41CE480) on Bowles Creek, Cherokee County, Texas. Journal of Northeast Texas Archaeology 71:55-60.

Stokes, J. and J. Woodring

1981 Native-Made Artifacts of Clay. In Archeological Investigations at the George C. Davis Site, Cherokee County, Texas: Summers of 1979 and 1980, edited by D. A. Story, pp. 135-238. Occasional Paper No. 1. Texas Archeological Research Laboratory, The University of Texas at Austin.

Story, D. A.

1965 The Archeology of Cedar Creek Reservoir, Henderson and Kaufman Counties, Texas. Bulletin of the Texas Archeological Society 36:163-257.

1969 1968-1969 Field Work at George C. Davis. Newsletter of the Southeast Archaeological Conference 13:25-32. 
1972 A Preliminary Report of the 1968, 1969, and 1970 Excavations at the George C. Davis Site, Cherokee County, Texas. Texas Archeological Research Laboratory The University of Texas.

1981 An Overview of the Archeology of East Texas. Plains Anthropologist 26(92):139-156.

1990 Cultural History of the Native Americans. In The Archeology and Bioarcheology of the Gulf Coastal Plain, by D. A. Story, J. A Guy, B. A. Burnett, M. D. Freeman, J. C. Rose, D. G. Steele, B. W. Olive, and K. J. Reinhard, pp. 163-366. Research Series No. 38. 2 Vols. Arkansas Archeological Survey, Fayetteville.

1990 Excavated Caddoan Sites with Coles Creek Style Ceramics. In The Archeology and Bioarcheology of the Gulf Coastal Plain, by D. A. Story, J. A Guy, B. A. Burnett, M. D. Freeman, J. C. Rose, D. G. Steele, B. W. Olive, and K. J. Reinhard, pp. 736-748. Research Series No. 38. 2 Vols. Arkansas Archeological Survey, Fayetteville.

1993 Alex D. Krieger. American Antiquity 58(4):614-621.

1997 1968-1970 Archeological Investigations at the George C. Davis Site, Cherokee County, Texas. Bulletin of the Texas Archeological Society 68:1-113.

1998 The George C. Davis Site: Glimpses into Early Caddoan Symbolism and Ideology. In The Native History of the Caddo: Their Place in Southeastern Archeology and Ethnohistory, edited by T. K. Perttula and J. E. Bruseth, pp. 9-43. Studies in Archeology 30. Texas Archeological Research Laboratory The University of Texas at Austin.

2000 Introduction. In The George C. Davis Site, Cherokee County, Texas, by H. P. Newell and A. D. Krieger, pp. 1-31. 2nd Edition. Society for American Archaeology, Washington, D.C.

Story, D. A. (editor)

1981 Archeological Investigations at the George C. Davis Site, Cherokee County, Texas: Summers 1979 and 1980. Occasional Papers, Vol. 1. Texas Archeological Research Laboratory, The University of Texas at Austin.

1982 The Deshazo Site, Nacogdoches County, Texas, Vol. 1: The Site, Its Setting, Investigations, Cultural Features, Artifacts of Non-Native Manufacture, and Subsistence Remains. Texas Antiquities Permit Series No. 7. Texas Antiquities Committee, Austin. 
1995 The Deshazo Site, Nacogdoches County, Texas, Vol. 2: Artifacts of Native Manufacture. Studies in Archeology 21. Texas Archeological Research Laboratory, The University of Texas at Austin.

Story, D. A. and D. G. Creel

1982 The Cultural Setting. In The Deshazo Site, Nacogdoches County, Texas, Vol. 1, edited by D. A. Story, pp. 20-34. Texas Antiquities Permit Series No. 7. Texas Antiquities Committee, Austin.

Story, D. A. and S. Valastro, Jr.

1977 Radiocarbon Dating and the George C. Davis Site, Texas. Journal of Field Archaeology 4(1):63-89.

Story, D. A., B. Barber, E. Cobb, H. Cobb, R. Coleman, K. Gilmore, R. K. Harris, and N. Hoffrichter

1967 Pottery Vessels. In "The Gilbert Site: A Norteno Focus Site in Northeast Texas," edited by E. B. Jelks. Bulletin of the Texas Archeological Society 37:112-187.

Story, D. A., J. A. Guy, B. A. Burnett, M. D. Freeman, J. C. Rose, D. G. Steele, B. W. Olive, and K. J. Reinhard

1990 The Archeology and Bioarcheology of the Gulf Coastal Plain. Research Series No. 38. 2 Vols. Arkansas Archeological Survey, Fayetteville.

Styles, B. W. and J. R. Purdue

1984 Faunal Exploitation at the Cedar Grove Site. In Cedar Grove: An Interdisciplinary Investigation of a Late Caddo Farmstead in the Red River Valley, edited by N. L. Trubowitz, pp. 211-226. Research Series No. 23. Arkansas Archeological Survey, Fayetteville.

Suhm, D. A. and E. B. Jelks (editors)

1962 Handbook of Texas Archeology: Type Descriptions. Special Publication No. 1, Texas Archeological Society, and Bulletin No. 4, Texas Memorial Museum, Austin. Reprinted in 2009, Gustav's Library, Davenport, lowa.

Suhm, D. A., A. D. Krieger, and E. B. Jelks

1954 An Introductory Handbook of Texas Archeology. Bulletin of the Texas Archeological Society 25:1-562.

Sullivan, S. M. and D. P. McKinnon

2013 The Collins Site (3WA1): Exploring Architectural Variation in the Western Ozark Highlands. Southeastern Archaeology 32(1):70-84.

Sullivan, T. L. 
1977 Archaeological Investigations at Lake Bob Sandlin, Texas. Research Report No. 99. Archaeology Research Program, Southern Methodist University, Dallas.

Sundermeyer, S. A., J. T. Penman, and T. K. Perttula

2008 Integrated Cultural Resources Investigations for the Bowie County Levee Realignment Project, Bowie County, Texas, and Little River County, Arkansas. Miscellaneous Reports, Report of Investigations No. 29. LopezGarcia Group, Dallas.

Sundermeyer, S. A., T. G. Baugh, J. Whaley, and M. McMinn 2004 Cultural Resource Investigations of 11 Archaeological Sites at Broken Bow Reservoir, McCurtain County, Oklahoma. Miscellaneous Reports, Report of Investigations No. 6. Lopez Garcia Group, Dallas.

Swanda, M.

1982 Archeological Investigations at Several Recreational Sites, Lake Ouachita, Arkansas. Report No. 19. Archeological Assessments, Inc., Nashville, Arkansas.

Swanda, M. and P. E. Brockington

1983 Report of Archeological Investigations at Robert S. Kerr Lock and Dam and Lake. Soil Systems Inc., Topeka, Kansas.

Swanda, M., A. F. Gettys, L. Raymer, D. Heffington, and W. J. Bennett, Jr. 1986 Test Excavations at the Beach Creek Site, 3CO19, Columbia County, Arkansas. Report No. 50. Archeological Assessments, Inc., Nashville, Arkansas.

Sweeney, J. J., J. Brown, and H. W. Hamilton

1965 Spiro and Mississippian Antiquities from the McDannald Collection. Museum of Fine Arts, Houston, Texas.

Swenson, F. E.

1989 Preliminary Studies in the Use of Petrographic and Proton Induced X-Ray Emission Analysis (PIXE). In Contributions to Spiro Archeology: Mound Excavations and Regional Perspectives, edited by J. D. Rogers, D. G. Wyckoff, and D. A. Peterson, pp. 177-186. Studies in Oklahoma's Past No. 16. Oklahoma Archeological Survey, Norman.

Taboada, M. B.

2011 Anthropology pioneer was known for study of Caddo Indians in East Texas: Dee Ann Story, 1931-2010. Newsletter of the Louisiana Archaelogical Society 39(1):5.

Tamers, Murray A., F. J. Pearson, Jr., and E. Mott Davis 
1964 University of Texas Radiocarbon Dates II. Radiocarbon 6:138-159.

Taormina, $\mathrm{K}$.

2015 An Architectural Analysis of Caddo Structures at the Ferguson Sote (3HE63). Master's thesis, Department of Anthropology, University of Arkansas, Fayetteville.

Taylor, A. J.

1986 Analysis of Ceramic Function: A Late Caddoan Example. Bulletin of the Texas Archeological Society 55:115-121.

Taylor, M. and D. Creel

2012 Biological Relationships between Foragers and Farmers of South-Central North America: Nonmetric Dental Traits. American Antiquity 77(1):99-114.

Taylor, R. A.

1972 The Cryer Manifestation: Definition and Tentative Placement in the Caddoan Sequence. The Arkansas Archeologist 13:41-66.

1987 An Archeological Survey of 430 Acres in the Lee Creek Unit of the Ozark National Forest; Crawford County, Arkansas. Report 87-1. Spears Professional Environmental and Archeological Research Service, Inc., West Fork, Arkansas.

Taylor, R. and M. Tate

1997 A Cultural Resources Survey of 2,378 Acres at the Martin Lake Area, Areas AIV and BIII, Panola and Rusk Counties, Texas. Document No. 960453. Espey, Huston \& Associates, Inc., Austin.

Thoburn, J. B.

1922 The Webber's Falls "Trap Dyke" as a Source of Material for Primitive Implement Makers. Proceedings of the Oklahoma Academy of Sciences 2:92-94.

1926 Oklahoma Archaeological Exploration. El Palacio 21:120-121.

1926 Progress Report on Oklahoma Archaeology. Proceedings of the Oklahoma Academy of Science 6:369-371.

1926 Oklahoma Archaeological Explorations in 1925-1926. The Chronicles of Oklahoma 4(2):143-148.

1929 The Prehistoric Cultures of Oklahoma. The Chronicles of Oklahoma 7(3) :211-241. 
1931 The Prehistoric Cultures of Oklahoma. In Archaeology of the Arkansas River Valley, by W. K. Moorehead, pp. 53-82. Yale University Press, New Haven.

Thomas, P. M., Jr., L. J. Campbell, and S. R. Ahler

1980 The Hanna Site: An Alto Focus Village in Red River Parish. Louisiana Archaeology 5:1-381.

Thomas, P. M., N. O. Wright, Jr., L. J. Campbell, and S. R. Ahler 1978 Excavations at 16NA171, Cognac Revetment, Natchitoches Parish. New World Research Inc., New Orleans. Report on file at the Louisiana Division of Archaeology, Department of Culture, Recreation, and Tourism, Baton Rouge.

Thomas, P. M., Jr., S. Shelley, L. J. Campbell, M. T. Swanson, C. S. Weed, and J.P. Lenzer

1982 Cultural Resources Investigations at the Fort Polk Military Reservation, Vernon, Sabine, and Natchitoches Parishes, Louisiana. New World Research, Inc., Pollock, Louisiana.

Thomas, R. A.

1963 3LR9: An Open Site in Southwest Arkansas. The Arkansas Archeologist 4(10):12-14.

Thomason, $\mathrm{H}$.

2004 Big Creek Streets and Approaches No. 2. Environmental Division, Arkansas Highways and Transportation Department, Little Rock.

Thompson, J. L., R. P. Mauldin, S. A. Tomka, and E. Okansen

2012 Archeological Testing and Data Recovery at the Flatrock Road Site, 41KM69, Kimble County, Texas. Archeological Studies Program, Report No. 133. Texas Department of Transportation, Environmental Affairs Division, Austin.

Thoms, A. V. (editor)

1997 The Upper Keechi Creek Archaeological Project: Survey and Test Excavations at the Keechi Creek Wildlife Management Area, Leon County, Texas. Technical Report No. 3. Center for Environmental Archaeology, Texas A\&M University, College Station.

Thurmond, J. P.

1981 Archeology of the Cypress Creek Drainage Basin, Northeastern Texas and Northwestern Louisiana. Master's thesis, Department of Anthropology, The University of Texas at Austin. 
1985 Late Caddoan Social Group Identifications and Sociopolitical Organization in the Upper Cypress Basin and Its Vicinity, Northeastern Texas. Bulletin of the Texas Archeological Society 54:185-200.

1990 Was the Cypress Cluster One of the (Many) Victims of the 1539-1543 De Soto Expedition? Caddoan Archeology Newsletter 1(3):5-11.

1990 Archeology of the Cypress Creek Drainage Basin, Northeastern Texas and Northwestern Louisiana. Studies in Archeology 5. Texas Archeological Research Laboratory, The University of Texas at Austin.

Thurmond, J. P. and U. Kleinschmidt

1979 Report on the Fall 1978 Investigations at the George C. Davis Site, Caddoan Mounds State Historic Site, Cherokee County, Texas. Texas Archeological Research Laboratory, The University of Texas at Austin.

Tiemann, M. and J. Belew

2010 Cultural Resources Investigation Report of the Proposed Approximately 8Acre Tract of Land Comprising a Planned Lake Site within the Mineola Nature Preserve on the Sabine River, Wood County, Texas. Sphere 3 Environmental, Inc., Longview.

Tiné, A. and L. Tieszen

1997 Bioarcheology. In Two Caddoan Farmsteads in the Red River Valley: The Archeology of the McLelland and Joe Clark Sites, edited by D. B. Kelley, pp. 121-137. Research Series 51. Arkansas Archeological Survey, Fayetteville.

Tine, A., C. R. Lintz, and M. Green

2007 Cultural Resources Survey of the Spiro Storage System Project, LeFlore and Haskell Counties, Oklahoma. Miscellaneous Reports of Investigations No. 333. Geo-Marine, Inc., Plano.

Todd, J.

1998 Conch Shell Cups and Black Drink. Caddoan Archeology 9(2):26-27.

2001 Insect Effigy Pendants. Caddoan Archeology 11(4):25-28.

2005 Spiro Mound Art and Its Possible Mythic Origins. Oklahoma Archeology 53(2):26-35.

2005 Two Separate Artistic Motifs at the Craig Mound? Oklahoma Archeology $53(4): 12$. 
2007 Cultural Resources Survey of a Proposed Equestrian/Biking Trail within the Mineola Preserve on the Sabine River, Wood County, Texas. Cultural Resources Letter Report 2007-51. AR Consultants, Inc., Dallas.

2010 Two Catlinite Pipe Fragments from the Womack Site, Lamar County, Texas. Caddo Archeology Journal 20:139-142.

2011 An Unique Shell Gorget from Wood County, Texas. Journal of Northeast Texas Archaeology 35:1-4.

2013 Preliminary Comments on Dog Interments from Archeological Sites in Northeast Texas: Folklore and Archeology. Caddo Archeology Journal 23:85-92.

2014 Looped and Perforated Elbow Pipes in Northeast Texas. Caddo Archeology Journal 24:161-166.

2014 Freshwater Mussel Shells: A Status Symbol at the Roitsch/Williams Sites in Red River County, Texas? Journal of Northeast Texas Archaeology 46:81-82.

2014 The Prehistoric Archeology of the Upper Trinity River Basin, Eastern North Central Texas. Archeological Journal of the Texas Prairie-Savannah 4:143.

Todd, J. and S. A. Skinner

2003 Archaeological Survey of the Lake Crook Trails, Lamar County, Texas. Cultural Resources Report 2003-21. AR Consultants, Inc., Dallas.

Todd, J. and L. T. Trask

2008 A Caddoan Sherd from Johnson County, Texas. The Record 56(1:4.

Todd, J. and R. L. Turner

2010 Clay Pipes from the Tuck Carpenter Site (41CP5). Caddo Archeology Journal 20:143-146.

Todd, J., S. A. Skinner, L. K. Trask, and A. Tawater

2011 Archeological Investigations at the Gilkey Hill Site (41DL406), Dallas County, Texas. Archeological Journal of the Texas Prairie Savannah 1(1):18-28.

Tomka, S. A., L. B. Love, and T. K. Perttula

2014 The Petrographic Analysis of Sherds from the Musgano Site (41RK19), Rusk County, Texas. Journal of Northeast Texas Archaeology 49:43-80.

Tomka, S. A., T. K. Perttula, T. Middlebrook, and M. K. Jackson 
2013 Native-made Historic Ceramics of Texas. Bulletin of the Texas Archeological Society 84:247-267.

Trissler, A.

1994 Caroline Dorman and Louisiana Archaeology of the 1930s. Master's thesis, Department of Anthropology, Northwestern State University of Louisiana, Natchitoches.

Trowbridge, H. M.

1938 Analysis of Spiro Mound Textiles. American Antiquity 4:51-53.

1944 The Trowbridge Collection of Spiro Mound Artifacts. The Illinois State Archaeological Journal, pp. 21-23.

Townsend, R. P. and C. P. Walker

2004 The Ancient Art of Caddo Ceramics. In Hero, Hawk, and Open Hand: American Indian Art of the Ancient Midwest and South, edited by R. P. Townsend, pp. 231-245. Art Institute of Chicago and Yale University Press, Chicago and New Haven.

Trierweiler, W. N. and M. L. Bonine

2003 A Cultural Resource Inventory of Selected Areas at Lake Sam Rayburn and Town Bluff Dam/Steinhagen Lake, Texas. Ecological Communications Corporation, Austin.

2004 Cultural Resource Inventory of 291 Acres at Lake O' the Pines, Upshur and Marion Counties, and Lake Wright Patman, Cass County, Texas. Ecological Communications Corporation, Austin.

Trierweiler, W. N. and V. Galan

2002 A Cultural Resource Survey of 52 Acres at Lake Sam Rayburn, Angelina and Jasper Counties, Texas. Ecological Communications Corporation, Austin.

Trierweiler, W. N., and R.S. Jones

2005 A Cultural Resource Inventory of 1,414 Acres at Lake Wright Patman and Lake O' the Pines, Bowie, Upshur and Marion Counties, Texas. Ecological Communications Corporation, Austin.

2006 Cultural Resources Inventory of 1,209 Acres at Lake Wright Patman and Lake O' the Pines, Bowie, Cass, Harrison, and Marion Counties, Texas. Ecological Communications Corporation, Austin.

Trierweiler, W. N., M. L. Bonine, and V. Galan 2002 Cultural Resource Inventories of Selected Areas at Four Lakes in East Texas. Ecological Communications Corporation, Austin. 
Troell, S. W. and J. T. Abbott

2012 Report for Intensive Survey, CR 1411 at Indian Creek, CSJ 0910-16-066. Texas Department of Transportation, Environmental Affairs Division, Archeological Studies Division, Austin.

Trubitt, M. B.

2002 Update on the Peeler Bend Canoe: An Ancient Dugout Canoe from Saline County. Field Notes (Newsletter of the Arkansas Archeological Society) 307:3-5.

2003 Archeological Salvage at the Rorie Place (3CL23). Field Notes (Newsletter of the Arkansas Archeological Society) 312:3-7.

2004 Archeological Testing at 3GA854, A Site on Lake Catherine in the Ouachita River Valley. Arkansas Archeological Survey, Henderson State University, Arkadelphia.

2005 Mapping a Novaculite Quarry in Hot Springs National Park. Caddoan Archeology Journal 14:17-33.

2006 M. R. Harrington (1882-1971). The Encyclopedia of Arkansas History \& Culture. On-line edition, http://www.encyclopediaofarkansas.net.

2006 New Archeological Testing at 3MN386, Caddo Indian Burial Ground Site. Limited distribution report, Arkansas Archeological Survey, Henderson State University Research Station, Arkadelphia.

2007 A New Topographic Map of Barkman Mound (3CL7). Field Notes (Newsletter of the Arkansas Archeological Society) 338: 3-4.

2007 The Organization of Novaculite Tool Production: Quarry-Workshop Debitage Comparisons. Caddo Archeology Journal 16:71-89.

2008 Letter Report to Mr. Blake Hogue of Entergy Re: 2007 Fall Survey of Lake Catherine. Limited distribution report, Arkansas Archeological Survey, Henderson State University Research Station, Arkadelphia.

2009 Burning and Burying Buildings: Exploring Variation in Caddo Architecture in Southwest Arkansas. Southeastern Archaeology 28(2):233-247.

2009 The First Residents: Native Americans in Garland County. In Garland County, Arkansas: Our History and Heritage, edited by I. B. Anthony, pp. 7-10. Garland County Historical Society and Melting Pot Genealogical Society, Hot Springs. 
2010 Two Shell Gorgets from Southwest Arkansas. Caddo Archeology Journal 20:129-137.

2012 Topographic Mapping of a Caddo Mound in Clark County. Field Notes (Newsletter of the Arkansas Archeological Society) 364:9-11.

2012 Report on the $53^{\text {rd }}$ Annual Caddo Conference. Caddo Archeology Journal 22:143-152.

2012 Caddo in the Saline River Valley of Arkansas: The Borderlands Project and the Hughes Site. In The Archaeology of the Caddo, edited by T. K. Perttula and C. P. Walker, pp. 288-312. University of Nebraska Press, Lincoln.

2012 A Fresh Look at the Hedges Site. Field Notes (Newsletter of the Arkansas Archeological Society) 367:8-12.

2016 Report on the 2015 Caddo Conference in Arkadelphia. Caddo Archeology Journal 26:80-86.

2016 Monitoring and Archeological Documentation at 3GA22, Hot Springs National Park, Garland County, Arkansas. Arkansas Archeological Survey, Henderson State University Research Station, Arkadelphia.

2017 Effigy Pottery in the Joint Educational Consortium's Hodges Collection. Caddo Archeology Journal 27:51-93.

2017 Update on Recent Activities at the Arkansas Archeological Survey's Henderson State University Research Station in Arkadelphia. Caddo Archeology Journal 27:102-104.

Trubitt, M. B. and M. Etchieson

2014 Plans for the 2014 Arkansas Archeological Society Training Program in the Ouachita National Forest. Field Notes (Newsletter of the Arkansas Archeological Society) 377:3-5.

Trubitt, M. B. and L. Evans

2015 Revisiting a Historic Manuscript: Vere Huddleston's Report on East Place (3CL21) Excavations. Caddo Archeology Journal 25:73-144.

Trubitt, M. B. and K. Leslie

2015 Identity \& Community in the Ouachita Mountains. http://archeology.uark.edu/learn-discover/current-research/ouachitamountains/. 
2016 2013-2014 Society Training Program Excavations: the Dates. Field Notes (Newsletter of the Arkansas Archeological Society)390:6-14.

Trubitt, M. B. and M. Reynolds

2007 Dating Caddo Indian Habitation at the Hughes Site (3SA11). Henderson State University's Academic Forum 24:28-39. On-line edition, http://www.hsu.edu/default.aspx?id=8538.

Trubitt, M. B. and K. Wright

2005 Archeological Test Excavations at Lake Ouachita, Arkansas. Limited distribution report submitted to the US Army Corps of Engineers, Vicksburg District, in accordance with Archaeological Resources Protection Act Permit No. DACW38-4-01-49, by the Arkansas Archeological Survey, Henderson Research Station, Arkadelphia.

Trubitt, M. B., L. L. Bush, L. S. Kelly, and K. Leslie

2016 Ouachita Mountains Foodways: Preliminary Results from 2013-2014 Excavations at 3MN298. Caddo Archeology Journal 26:50-79.

Trubitt, M. B., M. Etchieson, and L. L. Bush

2014 First Results from 3MN298: The Caddo Community. Field Notes, Newsletter of the Arkansas Archeological Society 377:10-14.

Trubitt, M. B., T. Green, and A. Early

2004 A Research Design for Investigating Novaculite Quarry Sites in the Ouachita Mountains. The Arkansas Archeologist 43:17-62.

Trubitt, M. B., K. Parker, and L. Kelly

2011 Reconstructing Ancient Foodways at the Jones Mill Site (3HS28), Hot Springs County, Arkansas. Caddo Archeology Journal 21:43-70.

Trubitt, M. B., T. K. Perttula, R. Z. Selden, Jr., and J. R. Ferguson 2016 Identifying Ceramic Exchange and Interaction between Cahokia and the Caddo Area. In Research, Preservation, Communication: Honoring Thomas J. Green on his Retirement from the Arkansas Archeological Survey, edited by M. B. Trubitt, pp. 87-102. Research Series No. 67, Arkansas Archeological Survey, Fayetteville.

Trubowitz, N. L.

1980 Pine Mountain Revisited: An Archeological Study in the Ozarks. Research Report No. 23. Arkansas Archeological Survey, Fayetteville.

1981 Research Progress Report on the Cedar Grove Site, a Late Caddo Farmstead on the Red River. Field Notes (Arkansas Archeological Society) 180:7-12. 
1982 Late Caddo Settlement and Society at the Cedar Grove Site. Field Notes (Newsletter of the Arkansas Archeological Society) 187:8-15.

1982 Test Excavations at 3J024-A Multicomponent Site in the Arkansas River Valley near Clarksville. Project Report No. 524. Arkansas Archeological Survey, Fayetteville.

1983 Caddoan Settlement in the Arkansas Ozarks: The Upper Lee Creek Valley. Midcontinental Journal of Archaeology 8(2):197-210.

Trubowitz, N. L. (editor)

1984 Cedar Grove: An Interdisciplinary Investigation of a Late Caddo Farmstead in the Red River Valley. Research Series No. 23. Arkansas Archeological Survey, Fayetteville.

Trubowitz, N. L., F. F. Schambach, and J. E. Miller III

1982 Test Excavations at 3LA128: An Early Caddo Occupation on the Red River. In Contributions to the Archeology of the Great Bend Region, edited by F. F. Schambach and F. Rackerby, pp. 39-54. Research Series No. 22. Arkansas Archeological Survey, Fayetteville.

Tucker, E., W. F. Stanyard, L. A. Thomas, and J. L. Holland

2008 Phase I Cultural Resource Investigations for the CenterPoint Delta Crossing Loop AC Project in Hot Spring County, Arkansas. TRC Project \#154874. TRC, Norcross, Georgia.

Tunnell, C. D.

1959 The Southall Site, 41UR3, Ferrell's Bridge Reservoir. MS on file, Texas Archeological Research Laboratory, The University of Texas at Austin.

1959 The Sam Roberts Site, Ferrell's Bridge Reservoir, Texas. MS on file, Texas Archeological Research Laboratory, The University of Texas at Austin.

Turner, B. D.

2008 Archeological Assessment of the Enbridge Sand Ridge to Oak Hill 16" Pipeline, Harrison and Gregg Counties, Texas. Technical Report 48. TAS, Inc., Canyon Lake.

2010 A Cultural Resource Assessment of Enbridge G \& P (East Texas) L.P., South Haynesville Expansion Pipeline Project, Panola and Shelby Counties, Texas. Technical Report 73. TAS Inc., Canyon Lake, Texas.

2010 Testing of Prehistoric Sites 41SY299 and 41SY300, South Haynesville Expansion Row, Risinger Creek Crossing, Shelby County, Texas. Cultural Resources Report 29. TAS, Inc., Canyon Lake, Texas. 
Turner, B. D. and J. Smart

2007 Cultural Resource Assessment Enbridge Pipeline Shelby to Henderson Plant Pipeline, Rusk County, Texas. Letter Report 64. TAS, Inc., Canyon Lake.

Turner, E. S., T. R. Hester, and R. L. McReynolds

2011 Stone Artifacts of Texas Indians: Completely Revised Third Edition. Taylor Trade Publishing, Lanham, Maryland.

Turner, K. and J. Hughey

2007 Cultural Resources Intensive Pedestrian Survey of Enbridges Proposed $D C$ 36-Inch Bethel to Crockett (DC-36-BC) Natural Gas Pipeline Segment in Houston and Anderson Counties, Texas. HRA Gray\& Pape, LLC, Houston.

Turner, M.

1993 A Two-Phase or Tiered Caddo Mound at the Camp Joy Site (41UR144), Lake O' the Pines. Notes on Northeast Texas Archaeology 2:66-75.

1994 From Soccer Socials to Caddo Archeology. The Cache, Collected Papers on Texas Archeology 2:69-72. Office of the State Archeologist, Texas Historical Commission, Austin.

Turner, R. L.

1978 The Tuck Carpenter Site and Its Relations to Other Sites within the Titus Focus. Bulletin of the Texas Archeological Society 49:1-110.

1992 Prehistoric Mortuary Remains at the Tuck Carpenter Site, Camp County, Texas. Studies in Archeology No. 10. Texas Archeological Research Laboratory, The University of Texas at Austin.

1995 Native American Ceramics of Northeast Texas. Texas Archeological Stewardship Network Newsletter 10(1):19-21.

1997 Analysis of the Asa Warner (41ML46) Ceramics. Bulletin of the Texas Archeological Society 68:231-239.

1997 Observations on Four Probable Middle Caddo Cemeteries in Camp and Upshur Counties. Journal of Northeast Texas Archaeology 10:12-35.

2008 Pottery from 41NA202: The Stephens Site in Nacogdoches County, Texas. Journal of Northeast Texas Archaeology 28:9-11.

Turner, R. L. and J. E. Smith II 
2003 The Harold Williams Site (41CP10) and the Texas Archeological Society Field School of 1967. Bulletin of the Texas Archeological Society 73:1-68.

Turner, T. S.

1977 An Assessment of the Archeological and Cultural Heritage of Wood County, Texas. The Record 33(2):1-10. Dallas Archeological Society, Dallas.

Turner-Pearson, $\mathrm{K}$.

2008 The Stone Site: A Waco Village Frozen in Time. Plains Anthropologist 53(208):565-576.

Turner-Pearson, K., K. Jordan, and C. F. Andrews

20112010 Archaeological Investigations at the Panther Creek Archaeological Site (34MC408), Broken Bow Reservoir, McCurtain County, Oklahoma. URS, Inc., Dallas.

Turpin, J. P.

2004 A Cultural Resource Assessment of the Enbridge Pipelines, L.P.: Double $D$ East Texas Pipeline Expansion Project, Anderson, Cherokee, Rusk, and Panola Counties, Texas. Technical Report 32. TAS Inc., Austin.

Turpin, S. A., J. Rabinowitz, J. Henderson, and P. E. Patterson

1976 A Statistical Examination of Caddoan Vessel Design and Shape from the Ben McKinney Site, Marion County, Texas. Plains Anthropologist 21(73):165-179.

Turpin, S. A and J. A. Neely

1977 An Automated Computer Technique for Vessel Form Analysis. Plains Anthropologist 22(78):313-319.

Valastro, S., Jr. and E.M. Davis

1970 University of Texas at Austin Radiocarbon Dates VII. Radiocarbon 12(1):249-280.

1970 University of Texas at Austin Radiocarbon Dates VIII. Radiocarbon 12 (No. 2):617-639.

Valastro, S., Jr., E. M. Davis, and A. G. Varela

1972 University of Texas at Austin Radiocarbon Dates IX. Radiocarbon 14(2):461-485.

1975 University of Texas at Austin Radiocarbon Dates X. Radiocarbon 17(1):52-98.

Valastro, S., Jr., E. M. Davis, A. G. Varela, and O. C. Ekland 
1980 University of Texas at Austin Radiocarbon Dates XIV. Radiocarbon 22(4):1090-1115.

Valastro, S., Jr., E. M. Davis, A. G. Varela, and S. V. Lisk

1988 University of Texas at Austin Radiocarbon Dates XVI. Radiocarbon 30(2):197-253.

Veatch, A. C.

1899 The Shreveport Area. In A Preliminary Report on the Geology of Louisiana, by G. D. Harris and A. C. Veatch, pp. 152-208. Special Paper 2, Part 5. Geology and Agriculture of Louisiana, Louisiana State Experiment Station, Baton Rouge.

Vehik, R.

1979 Archaeological Test Excavations at the Buffalo Bend Site (34Pu-111), Southeast Oklahoma. Oklahoma Anthropological Society Newsletter 27(3):3-5.

1982 The Archaeology of the Bug Hill Site (34Pu-116): Pushmataha County, Oklahoma. Research Series No. 7. Archeological Research and Management Center, University of Oklahoma, Norman.

1989 Shell-Tempered Jar from the Copeland Site (34LF20). Oklahoma Anthropological Society Newsletter 37(2):5-6.

1989 The Four Pines Site (34PU108), Pushmataha County, Oklahoma. Bulletin of the Oklahoma Anthropological Society 38:49-78.

Vehik, R. (editor)

1982 Phase II Archaeological Investigations at Clayton Lake, Southeast Oklahoma. Research Series No. 8. Archaeological Research and Management Center, University of Oklahoma, Norman.

Vehik, R. and J. R. Galm (editors)

1979 The Prehistory of the Proposed Clayton Lake Area, Southeast Oklahoma: Phase I Investigations. Research Series No. 6. Archaeological Research and Management Center, University of Oklahoma, Norman.

Vehik, R., C. Lintz, and S. J. Bobalik

1980 A Brief Review of Phase I and II Investigations of the Clayton Lake Area, Southeast Oklahoma. Oklahoma Anthropological Society Newsletter 28(5):8-10.

Vehik, S. C.

1984 The Woodland Occupations. In Prehistory of Oklahoma, edited by R. E. Bell, pp. 175-197. Academic Press, New York. 
1990 Late Prehistoric Exchange on the Southern Plains and Its Periphery. Midcontinental Journal of Archaeology 13(1):41-68.

Vehik, S. C. and T. G. Baugh

1994 Prehistoric Plains Trade. In Prehistoric Exchange Systems in North America, edited by T G. Baugh and J. E. Ericson, pp. 249-274. Plenum Press, New York.

Verlet, M. M.

1964 The Camden Ceramic Complex within Ouachita County, Arkansas. Master's thesis, Department of Anthropology, University of Illinois, Urbana.

Vogel, G.

2005 Cavanaugh: A Late Prehistoric Platform Mound in Western Arkansas. Caddoan Archeology Journal 14:35-65.

2005 A View From the Bottomlands: Late Prehistoric Mound Centers and Their Relationship to the Landscape in the Northern Caddo Area. Ph.D. dissertation, Department of Anthropology, University of Arkansas, Fayetteville.

2012 Viewshed Characteristics of Caddo Mounds in the Arkansas Basin. In The Archaeology of the Caddo, edited by T. K. Perttula and C. P. Walker, pp. 139-176. University of Nebraska Press, Lincoln.

2014 The Page Site and Mound Preservation in the Northern Caddo Area: Multiple Approaches to Understanding and Preserving the Prehistoric Past. Ploymath: An Interdisciplinary Journal of Arts \& Sciences 4(3):1-20.

Vogel, G., M. Kay, and L. Vogele Jr.

2005 A Platform Mound at the Norman Site (34Wg2), Eastern Oklahoma. Southeastern Archaeology 24(1):28-45.

Vogel, M. B.

2001 Volunteers Document Rock Art at Petit Jean State Park. Field Notes (Newsletter of the Arkansas Archeological Society) 298:3-4.

Vogele, L. E., Jr.

1982 The Turner Cave Site, 3MA20. Master's thesis, Department of Anthropology, University of Arkansas, Fayetteville.

1990 Turner Cave: A Rock Shelter in Northwest Arkansas. The Arkansas Archeologist 29:1-35.

Waddell, D. B. 
1981 An Archeological Survey of the Proposed Sewer Improvements Project Area for the City of Emmet, Nevada, and Hempstead Counties, Arkansas. Project Report No. 490. Arkansas Archeological Survey, Fayetteville.

1982 Test Excavations of Four Sites within the Lake Catherine Sewer Improvement District No. 19, Garland County, Arkansas. Project Report No. 547. Arkansas Archeological Survey, Fayetteville.

1987 Data Recovery Excavations Conducted at the Hardman Site (3CL418). Field Notes (Newsletter of the Arkansas Archeological Society) 219:9-10.

1991 Phase 1 Cultural Resource Survey of the Proposed Oklahoma Arkansas Pipeline Project Right-of-Way, Mile Posts 140.2186.7, in Pope and Conway Counties, Arkansas. Report No. 90-10. Spears Professional Environmental and Archeological Research Service, Inc., West Fork, Arkansas.

Waddell, D. B. and S. K. Blaylock

1982 An Intensive Cultural Resource Survey of Six Revetments and A Channel Realignment/Cutoff along the Red River in Southwestern Arkansas. Project Report No. 397. Arkansas Archeological Survey, Fayetteville.

Waddell, D. B. and E. Z. Waddell

1992 An Archeological Survey of 7,985 Acres in the Winona, Womble, Caddo, Mena, Kiamichi, and Choctaw Districts of the Ouachita National Forest, Arkansas and Oklahoma. Project Report 41. Spears Professional Environmental and Archeological Research Service, Inc., West Fork, Arkansas.

Waddell, D. B., E. Z. Waddell, K. Hoffman, M. Hughes, and J. D. Coble 1993 An Archeological Survey of 10,723 Acres in the Choctaw, Kiamichi, Tiak, Mena, Poteau and Oden Districts of the Ouachita National Forest, Arkansas and Oklahoma. Project Report 56. Spears Professional Environmental and Archeological Research Service, Inc., West Fork, Arkansas.

Waddell, D. B., E. Z. Waddell, K. Hoffman, and A. L. Moerbe 1995 An Archeological Survey of 8,939 Acres in the Caddo, Cold Springs, Fourche, Jessieville, Winona, and Womble Districts of the Ouachita National Forest, Garland Hot Springs, Montgomery, Perry, Scott, and Yell Counties, Arkansas. Project Report 66. Spears Professional Environmental and Archeological Research Service, Inc., West Fork, Arkansas.

Wagner, G. E. and P. H. Carrington 
2014 Sumpweed or Marshelder (Iva annua). In New Lives for Ancient and Extinct Crops, edited by P. E. Minnis, pp. 65-101. University of Arizona Press, Tucson.

Wakefield, E. G. and S. C. Dellinger

1936 Diet of Bluff Dwellers of the Ozark Mountains and its skeletal effect. Annals of Internal Medicine 9:1412-1418.

Walker, C. P.

2007 Report of Technical Findings: Geophysical Survey at Three Sites in Smith County, Texas. AGA Report 2007-13. Archaeo-Geophysical Associates, LLC, Austin.

2009 Landscape Archaeogeophysics: A Study of Magnetometer Surveys from Etowah (9BW1), The George C. Davis Site (41CE19), and the Hill Farm Site (41BW169). Ph.D. Dissertation, Department of Anthropology, The University of Texas at Austin.

2011 Geophysical Survey at the George C. Davis Site (41CE19) South of Highway 21, Cherokee County, Texas. AGA Report 2011-6. ArchaeoGeophysical Associates, LLC, Austin.

Walker, C. P. and D. P. McKinnon

2012 Exploring Prehistoric Caddo Communities through Archaeogeophysics. In The Archaeology of the Caddo, edited by T. K. Perttula and C. P. Walker, pp. 177-208. University of Nebraska Press, Lincoln.

Walker, C. P. and T. K. Perttula

2007 Remote Sensing at the Horace Cabe Site (41BW14). Caddo Archeology Journal 16:37-44.

2008 Geophysical Investigations on Caddo Sites in East Texas and Surrounding States. Bulletin of the Texas Archeological Society 79:159176.

2010 Archaeogeophysical Investigations at an Eighteenth-Century Caddo Site in Nacogdoches County, Texas. Southeastern Archaeology 29(2):310322.

2011 Archaeogeophysics and Archaeological Investigations at a Historic Caddo Site Along El Camino Real de los Tejas: The J. T. King Site (41NA15) in Nacogdoches County, Texas. Archaeo-Geophysical Associates, LLC and Archeological \& Environmental Consultants, LLC, Austin.

Walker, C. P. and T. C. Schultz 
2008 Magnetometer Survey and Results. In Integrated Cultural Resources Investigations for the Bowie County Levee Realignment Project, Bowie County, Texas and Little River County, Arkansas, by S. A. Sundermeyer, J. T. Penman, and T. K. Perttula, pp. 167-183. Miscellaneous Reports, Report of Investigations No. 29. LopezGarcia Group, Dallas.

Walker, C. P., T. K. Perttula, T. Middlebrook, B. Nelson, and M. Walters 2009 Volunteer Archaeogeophysics at an Historic Caddo Indian Site in East Texas. ISAP News 20:7-8. Newsletter of the International Society for Archaeological Prospection.

Walker, W. M.

1932 A Reconnaissance of Northern Louisiana Mounds. In Explorations and Fieldwork of the Smithsonian Institution in 1931. Smithsonian Institution, Washington, D.C.

1934 A Variety of Caddo Pottery from Louisiana. Journal of the Washington Academy of Sciences 24(2):99-104.

1935 A Caddo Burial Site at Natchitoches, Louisiana. Miscellaneous Collections 94(14):1-15. Smithsonian Institution, Washington, D.C.

Wallace, B. J.

1962 Prehistoric House Patterns of Oklahoma. Bulletin of the Oklahoma Anthropological Society 10:27-68.

Wallis, C. S., Jr.

1975 Two New Radiocarbon Dates for McCurtain County, Oklahoma. Oklahoma Anthropological Society Newsletter 23(8):5-13.

1979 Recent Review of 34At-160, Bo McAlister Site, Impoundment \#20, Lower Clear Bogy Creek Watershed Atoka County, Oklahoma. Miscellaneous Report Series No. 5. Oklahoma Conservation Commission, Oklahoma City.

1980 A Review of Cultural Resources Within Proposed Impoundment Locales $3 A$ and $3 B$, Sans Bois Creek Watershed, Latimer County, Oklahoma. General Survey Report 1980(1), Oklahoma Conservation Commission, Oklahoma City.

1986 Inventory of Native American Human Remains Recovered as a Result of U.S.D.A., Soil Conservation Service, Projects Within Oklahoma. Miscellaneous Report Series No. 20, Oklahoma Conservation Commission, Oklahoma City. 
1989 Evaluating a Potentially Important Prehistoric Site in Pittsburg County. Bulletin of the Oklahoma Anthropological Society 38:99-147.

1991 Survey of a Portion of Proposed Impoundment 19, Lower Clear Boggy Creek Watershed, Atoka County, Oklahoma. General Survey Report 1991(8), Oklahoma Conservation Commission, Oklahoma City.

Walters, M.

1997 The Langford Site (41SM197), Smith County, Texas. Journal of Northeast Texas Archaeology 9:38-41.

1998 A Keno Trailed Vessel from the Spoonbill Site in Wood County, Texas. Journal of Northeast Texas Archaeology 11:46-48.

2001 Archaeological Investigations and Oxidizable Carbon Ratio Dates from 41RK476, Rusk County, Texas. Journal of Northeast Texas Archaeology 15:9-27.

2003 The Wolf Site (41SM195), Smith County, Texas. Journal of Northeast Texas Archaeology 18:1-21.

2003 Survey at the Grandview Spring Fling 2003. Field Notes (Newsletter of the Arkansas Archeological Society) 312:8.

2004 41SM195A, the Browning Site. Caddoan Archeology Journal 13 (No. 3/4):19-20.

2004 41SM195A, the Browning Site. Journal of Northeast Texas Archaeology 20:1-42.

2004 A Profile in East Texas Archeology. Bulletin of the Texas Archeological Society $75: 119-121$.

2006 Turquoise Pendant. Journal of Northeast Texas Archaeology 24:84-88.

2006 The Lake Clear (41SM243) Site and Crotalus horridus atricaudatus. Caddoan Archeology Journal 15:5-41.

2007 Late Titus Phase Sites along Caney Creek in Northern Wood County, Texas. Journal of Northeast Texas Archaeology 26:145-149.

2009 Prehistoric Ceramics from the Browning Site (41SM195A). Journal of Northeast Texas Archaeology 29:1-7.

2009 The Henry Chapman Site (41SM56). Journal of Northeast Texas Archaeology 31:11-35. 
2009 Caddo Origins, A Smith County Perspective. Journal of Northeast Texas Archaeology 31:87-91.

2011 Perforated Spatulate Celt from East Texas. Newsletter of the Louisiana Archaeological Society 38(3):16.

2014 East Texas Archeological Society, Tyler, Texas, 1956-1959. Journal of Northeast Texas Archaeology 47:43-90.

2016 A House Burning at Redwine (41SM193). Journal of Northeast Texas Archaeology 65:99-104.

2016 An Unusual Caddo Bottle from the Walters Collection. Journal of Northeast Texas Archaeology 65:105-110.

Walters, M. and P. Haskins

1998 Archaeological Investigations at the Redwine Site (41SM193), Smith County, Texas. Journal of Northeast Texas Archaeology 11:1-38.

2000 The Bryan Hardy Site (41SM55), Smith County, Texas. Journal of Northeast Texas Archaeology 12:1-26.

Walters, M. and T. K. Perttula

2009 Recent Documentation of a Profile in Mound A at the Jamestown Mound Site (41SM54), Smith County, Texas. Texas Archeology (Newsletter of the Texas Archeological Society) 53(3):16-17.

2010 The Holmes Site (41SM282): An East Texas Site with Lower Mississippi Valley Ceramic Sherds. Louisiana Archaeology 31:34-42.

2011 New Radiocarbon Dates from Two Caddo Mound Centers in East Texas. Texas Archeology (Newsletter of the Texas Archeological Society) 55(2):14-16.

2012 Certain Caddo Sites on Stone Chimney Creek, Cherokee County, Texas. Journal of Northeast Texas Archaeology 37:37-88.

2014 41SM53 (P-4) on Prairie Creek, Smith County, Texas. Journal of Northeast Texas Archaeology 46:63-68.

2016 Sam Whiteside's Prairie Creek Sites in Smith County, Texas. Journal of Northeast Texas Archaeology 58:1-12.

2016 Ceramic Beads from the Cloud Hammond Site (41SM244), Smith County, Texas. Journal of Northeast Texas Archaeology 58:13-14. 
Walters, M., with contributions by T. Middlebrook and T. K. Perttula

2010 Redwine or Pie-Crust Mode Forms in East Texas Caddo Ceramics and comparisons with Sprocket-Rims of Southwest Arkansas. Caddo Archeology Journal 20:77-128.

Walters, M., B. Boyd, B. Nelson, T. K. Perttula, and L. Schniebs

2003 The James Owens Site (41TT769) in the Sulphur River Basin of Northeast Texas. Caddoan Archeology Journal 13(1):16-34.

Walters, M., with contributions from L. G. Cecil, L. S. Cummings, J. P. Dering, J. R. Ferguson, M. D. Glascock, T. K. Perttula, L. Schniebs, H. J. Shafer, J. Todd, and C. P. Walker

2008 Life on Jackson Creek, Smith County, Texas: Archeological Investigations of a $14^{\text {th }}$ Century Caddo Domicile at the Leaning Rock Site (41SM325). Caddo Archeology Journal 17:1-114.

Ward, H. T.

1967 Comments on the Occurrence of Caddoan Pottery in Southwestern Missouri. Plains Anthropologist 12(36):211.

Watkins, C.

1973 Caddoan Pottery Restored. Popular Archeology 2(5):33.

Watkins, E. and C. Hanson

2009 Intensive Cultural Resources Survey of the Thermo Mine, Permit 5F, A.1 Auxiliary Area, Hopkins County, Texas. Document No. 090140. PBS\&J, Austin.

Watkins, E. et al.

2007 Intensive Cultural Resources Survey of the TXU Leesburg Mine Outyears Area, Camp County, Texas. Document No. 070164. PBS\&J, Austin.

Watkins, J. H.

2006 A Phase I Cultural Resources Survey at a Proposed 20.5 Mile Pipeline Extending from Carthage, Texas to Keatchie, DeSoto Parish, Louisiana. University of Alabama, Office of Archaeological Research, Tuscaloosa.

2008 Phase I Cultural Resources Survey of Gulf South Pipeline Company's Proposed East Texas to Mississippian Expansion Project. University of Alabama, Office of Archaeological Research, Tuscaloosa.

Watt, F. H.

1941 Preliminary Report on Potsherds from the Chupik Site. Newsletter of the Central Texas Archeological Society 4:17-19. 
1953 Pottery Diffusions of the Central Brazos Valley. Central Texas Archeologist 7:6-29.

1956 Archeological Materials from the Asa Warner Sites. Central Texas Archeologist 7:6-29.

1965 Notes on the Clark Site, McLennan County, Texas. Bulletin of the Texas Archeological Society 36:99-110.

Webb, C. H.

1940 House Types Among the Caddo Indians. Bulletin of the Texas Archeological and Paleontological Society 12:49-75.

1941 Archaeology of Northwest Louisiana. Southeastern Archaeological Conference Newsletter 4(2):22-23.

1944 Dental Abnormalities as Found in the American Indian. American Journal of Orthodontics and Oral Surgery 30(9) :474-486.

1945 A Second Historic Caddo Site at Natchitoches, Louisiana. Bulletin of the Texas Archeological and Paleontological Society 16:52-83.

1948 Caddoan Prehistory: The Bossier Focus. Bulletin of the Texas Archeological and Paleontological Society 19:100-143.

1955 Comments Concerning the East Texas Section of "An Introductory Handbook of Texas Archeology." Bulletin of the Texas Archeological Society 26:259-271.

1956 Elements of the Southern Cult in the Belcher Focus. Southeastern Archaeological Conference Newsletter 5(1):21-30.

1959 The Belcher Mound, a Stratified Caddoan Site in Caddo Parish, Louisiana. Memoirs No. 16. Society for American Archaeology, Salt Lake City.

1960 A Review of Northeast Texas Archaeology. Bulletin of the Texas Archeological Society 29:35-62.

1961 Relationships Between the Caddoan and Central Louisiana Culture Sequences. Bulletin of the Texas Archeological Society 31:11-21.

1962 Early 19th Century Trade Material from the Colfax Ferry Site, Natchitoches Parish, Louisiana. Southeastern Archaeological Conference Newsletter 8:30-33. 
1963 The Smithport Landing Site: An Alto Focus Component in De Soto Parish, Louisiana. Bulletin of the Texas Archeological Society 32:143-187.

1978 Changing Archeological Methods and Theory in the Trans-Mississippi South. In Texas Archeology: Essays Honoring R King Harris, edited by K. D. House, pp. 27-45. Southern Methodist University Press, Dallas.

1983 The Bossier Focus Revisited: Montgomery I, Werner, and other Unicomponent Sites. In Southeastern Natives and Their Pasts, edited by D. G. Wyckoff and J. L. Hofman, pp. 183-240. Studies in Oklahoma's Past No. 11. Oklahoma Archeological Survey, Norman.

1984 The Bellevue Focus: A Marksville-Troyville Manifestation in Northwestern Louisiana. Louisiana Archaeology 9:251-274.

Webb, C. H. and M. Dodd, Jr.

1939 Further Excavations of the Gahagan Mound: Connections with a Florida Culture. Bulletin of the Texas Archeological and Paleontological Society 11:92-126.

1939 Bone "Gorges" from a Caddoan Mound Burial. American Antiquity 4(3):265-268.

1941 Pottery Types from the Belcher Mound Site. Bulletin of the Texas Archeological and Paleontological Society 13:88-116.

Webb, C. H. and H. F. Gregory

1986 The Caddo Indians of Louisiana. 2nd Edition. Anthropological Study 2. Department of Culture, Recreation, and Tourism, Louisiana Archaeological Survey and Antiquities Commission, Baton Rouge.

Webb, C. H. and D. R. Jeane

1977 The Springhill Airport Sites, J. C. Montgomery I (16WE32) and II (16WE33). Louisiana Archaeological Society Newsletter 4(3):3-7.

Webb, C. H. and R. R. McKinney

1963 An Unusual Pottery Vessel from Mounds Plantation, Caddo Parish, Louisiana. The Arkansas Archeologist 4(5):1-9.

1975 Mounds Plantation (16CD12), Caddo Parish, Louisiana. Louisiana Archaeology 2:39-127.

Webb, C. H., D. R. Jeane, and A. Jeane

1977 Springhill Airport Development Master Plan, Archaeological and Historical Survey Report, Webster Parish, Louisiana. Louisiana Division of Archaeology, Baton Rouge. 
Webb, C. H., F. E. Murphey, W. G. Ellis, and H. R. Green

1969 The Resch Site, 41HS16, Harrison County, Texas. Bulletin of the Texas Archeological Society 40:3-106.

Weber, J. C.

1971 The Hays Mound: A Very Preliminary Report. Arkansas Archeological Society Field Notes 76:3-6.

1972 "Lizard" Effigy Pendants. Field Notes (Newsletter of the Arkansas Archeological Society) 90:4-5.

1973 The Hays Mound 3CL6 Clark County, South Central Arkansas. Arkansas Archeological Survey, Fayetteville.

n.d. Study of the M. R Harrington Collection of Caddoan Materials from Arkansas. Arkansas Archeological Survey, Fayetteville.

Wedel, W. R.

1959 An Introduction to Kansas Archeology. Bulletin No. 174. Bureau of American Ethnology, Smithsonian Institution, Washington, D.C.

Weinstein, R. A. and G. J. DuCote

1979 A Sample-Based Cultural Resources Survey of the Proposed Grand Bayou Reservoir, Red River Parish, Louisiana. Coastal Environments, Inc., Baton Rouge.

Weinstein, R. A. and D. B. Kelley

1984 Archaeology and Paleogeography of the Upper Felsenthal Region: Cultural Resources Investigations in the Calion Navigation Pool, SouthCentral Arkansas. Coastal Environments, Inc., Baton Rouge.

Weinstein, R. A., D. B. Kelley, and J. W. Saunders

2003 Introduction. In The Louisiana and Arkansas Expeditions of Clarence Bloomfield Moore, edited by R. A. Weinstein, D. B. Kelley, and J. W. Saunders, pp. 1-213. The University of Alabama Press, Tuscaloosa and London.

Weinstein, R. A., D. B. Kelley, and J. W. Saunders (editors)

2003 The Louisiana and Arkansas Expeditions of Clarence Bloomfield Moore. University of Alabama Press, Tuscaloosa.

Wells, T.

1997 Cultural Resources Survey of Pools 3 and 4 Inundation Lands, Red River Waterway, Louisiana. Coastal Environments, Inc., Baton Rouge. 
Werner, $\mathrm{V}$.

2009 Phase III Archaeological Data Recovery at Sites 34DL300 and 34DL301, Delaware County, Oklahoma. Report submitted to the Bureau of Indian Affairs, Eastern Oklahoma Region, Muskogee by AMEC Environmental Consultants.

West, L., M. B. Cliff, F. King, and C. Sills

2003 Results of a Cultural Resource Survey Across the Floodplain of Big Cypress Creek for the Proposed Enbridge 4-Inch Natural Gas Pipeline Project, Morris and Camp Counties, Texas. Document No. 450925. PBS\&J, Austin.

Westbury, W. A.

1968 Test Excavations in DeQueen Reservoir Southwest Arkansas. University of Arkansas Museum, Fayetteville.

White, N. M. and R. A. Weinstein

2008 The Mexican Connection and the Far West of the U.S. Southeast. American Antiquity 73(2):227-277.

White, S.

1940 Human Effigy Pipes from Spiro Mound, LeFlore County, Oklahoma. The Oklahoma Prehistorian 3(1):10-11.

White, W. D., Jr., S. M. Hunt, and M. B. Cliff

1995 Cultural Resources Survey of 1,290 Acres at Wright Patman Lake, Bowie and Cass Counties, Texas. Miscellaneous Report of Investigations No. 99. Geo-Marine, Inc., Plano.

Whiteford, A.D.

1941 Textile Fibers Used in Eastern Aboriginal North America. Anthropological Papers of the American Museum of Natural History 38(1):1-22.

1943 Fiber Plants of North American Aborigines. Journal of the New York Botanical Garden 44(518):25-34.

Whiteside, S.

1959 Vessel from the Bryan Hardy Site. Ancient News 1, No. 1. News Letter of the East Texas Archeological Society, Tyler.

Wiewel, R.

2014 Constructing Community in the Central Arkansas River Valley: Ceramic Compositional Analysis and Collaborative Archaeology. Ph.D. dissertation, Department of Anthropology, University of Arkansas, Fayetteville.

Wilder, M. and R. C. Fields 
2005 Interim Report on Auger Sampling of 10 Sites, U.S. Highway 271 Mount Pleasant Relief Route, Titus County, Texas (CSJ 0919-30-027). Prewitt and Associates, Inc., Austin, Texas.

Wilder, M. C., S. L. Katauskas, R. C. Fields, E. F. Gadus, L. Kittrell, J. K. McWilliams, and J. E. Dockall

2007 Archeological and Historic Resources Survey of 1,931 Acres in the Sabine Mine's Area Q, Harrison County, Texas. Reports of Investigations No. 152. Prewitt and Associates, Inc., Austin.

Williams, B.

1953 The Ward Site, LeFlore County, Oklahoma. Oklahoma Anthropological Society Newsletter 1(9) :2-9.

Williams, B., D. Turpin, and R. Waldon

1998 An Archeological Survey for a Proposed Timber Sale and Associated Actions Various Compartments of the Mena Ranger District and Oden Ranger District, Montgomery, Polk and Scott Counties, Arkansas. Ouachita Cultural Resources Report No. 194. Ouachita National Forest, Hot Springs.

Williams, G. I., Jr.

1993 Features and Dating. In Caddoan Saltmakers in the Ouachita Valley, edited by A. M. Early, pp. 37-48. Research Series No. 43. Arkansas Archeological Survey Research Series, Fayetteville.

Williams, G. I., M. B. Reed, L. E. Abbott, J. W. Joseph, and C. Abrams 1993 An Archeological Survey of 7,741 Acres in the Caddo, Cold Springs, Fourche, Poteau, and Womble Districts of the Ouachita National Forest, Scott, Yell, Garland, and Montgomery Counties, Arkansas. Technical Report 147. New South Associates, Stone Mountain.

Williams, G. I., M. B. Reed, C. Hanson, C. L. Abrams, and L. E. Raymer 1994 An Archeological Survey of 2,136 Acres in the Oden, Poteau, and Tiak Districts of the Ouachita National Forest, Scott and Montgomery Counties, Arkansas and McCurtain County, Oklahoma. Technical Report No. 166. New South Associates, Stone Mountain, Georgia.

Williams, I.

1987 A Cultural Resources Survey of the Proposed Arkla Interconnect with the Transark Pipeline in Sebastian County Arkansas. Project Report No. 630. Arkansas Archeological Survey, Fayetteville.

Williams, J. M.

2007 GIS Aided Archaeological Research of El Camino Real de Los Tejas with Focus on the Landscape and River Crossings along El Camino Carretera. 
Master of Spatial Science, Stephen F. Austin State University, Nacogdoches, Texas.

Williams, M. L.

2000 Ethnobotanical Analysis (Winding Stair and Bug Spot). In Forest Farmsteads: A Millennium of Human Occupation at Winding Stair in the Ouachita Mountains, edited by Ann M. Early, pp. 111-122. Research Series 57. Arkansas Archeological Survey, Fayetteville.

Williams, S.

1961 A Proposal for the Revision of Terminology for the Historic Phases (foci) in the Caddoan Area. Bulletin of the Texas Archeological Society 31:122130.

1964 The Aboriginal Location of the Kadohadacho and Related Tribes. In Explorations in Cultural Anthropology, edited by W. H. Goodenough, pp. 545-570. Yale University Press, New Haven.

Williamson, D.

1991 Archeological Investigations at 3MN2, Montgomery County, Arkansas. AHTD Job 3997. Arkansas Highway and Transportation Department Job 3997. Arkansas Highway and Transportation Department, Environmental Division, Little Rock.

2001 Archeological Investigations of Sites 3MI59 and 3MI63 on AHTD Project FA4609, Old McKinney Bayou Bridge, County Road 14 Miller County, Arkansas. AHTD Job \# FA4609. Arkansas Highway and Transportation Department, Environmental Division, Little Rock.

Willoughby, C. C.

1952 Textile Fabrics from the Spiro Mound. The Missouri Archaeologist 14:107118.

Wilmsen, E. N.

1961 A Suggested Developmental Sequence for House Forms in the Caddoan Area. Bulletin of the Texas Archeological Society 30:35-49.

Wilson, A. M.

1950 Indian Life in Van Zandt County. In History of Van Zandt County, by J. Mills, pp. 67-79. Wills Point, Texas.

Wilson, D.

1993 The Sexual Division of Labor at the Sanders Site (41LR2), Lamar County Texas. Caddoan Archeology Newsletter 4(3):6-13. 
1994 Division of Labor and Stress Loads at the Sanders Site (41LR2), Lamar County, Texas. Bulletin of the Texas Archeological Society 65:129-160.

1995 Dental Paleopathologies in the Sanders Site (41LR2) Population from Lamar County. Journal of Northeast Texas Archaeology 5:29-59.

1997 Dental Paleopathology in the Sanders (41LR2) and Mitchell (41BW4) Populations from the Red River Valley, Northeast Texas. Bulletin of the Texas Archeological Society 68:147-159.

2003 Analysis of the Human Remains from Burials 1 and 2 from the Nawi haia ina site (41RK170). In The Nawi haia ina Site (41RK170): Archeological Investigations in the City of Henderson's Southside Wastewater Treatment Plant, Rusk County, Texas, by T. K. Perttula and B. Nelson, pp. 122-132. Report of Investigations No. 51. Archeological \& Environmental Consultants, LLC, Austin.

2004 Analysis of Human Remains from the 41CP71 Cemetery Area. In Archeological Investigations at the Shelby Site (41CP71) on Greasy Creek, Camp County, Texas, by T. K. Perttula and B. Nelson, pp. 156166. Special Publication No. 5. Friends of Northeast Texas Archaeology, Pittsburg and Austin.

2006 Human Remains in the Collection. In A Study of the Buddy Calvin Jones Collection from Northeast Texas Caddo Sites, by T. K. Perttula, pp. 110133. Special Publication No. 6. Friends of Northeast Texas Archaeology, Pittsburg and Austin.

2008 Human Remains. In Lake Naconiche Archeology, Nacogdoches County, Texas: Results of the Data Recovery Excavations at Five Prehistoric Archeological Sites, edited by T. K. Perttula, pp. 557-579. 2 Vols. Report of Investigations No. 60. Archeological \& Environmental Consultants, LLC, Austin.

2011 Analysis of Human Remains from the Lang Pasture Site. In Archeological Investigations at the Lang Pasture Site (41AN38) in the Upper Neches River Basin of East Texas, assembled and edited by T. K. Perttula, D. B. Kelley, and R. A. Ricklis, pp. 381-401. Report No. 129. Texas Department of Transportation, Archeological Studies Program, Environmental Affairs Division, Austin.

2012 Bioarchaeological Evidence of Subsistence Strategies among the East Texas Caddo. In The Archaeology of the Caddo, edited by T. K. Perttula and C. P. Walker, pp. 86-116. University of Nebraska Press, Lincoln. 
2012 Human Remains. In Archeology of the Nadaco Caddo: The View from the Pine Tree Mound Site (41HS15), Harrison County, Texas, edited by R. C. Fields and E. F. Gadus, pp. 693-726. Reports of Investigations No. 164. Prewitt \& Associates, Inc., Austin.

2016 Human Remains from the Ingram Cartwright Farm, East of San Augustine, along Highway 21, Texas. A. M. Wilson \& Associates, Inc., Marston Mills, Massachusetts.

Wilson, D. and D. Cargill

1993 Stable Isotope Analysis from the Sanders Site (41LR2). Caddoan Archeology Newsletter 4(3):3.

Wilson, D. and S. Derrick

1996 Cranial Modeling Among the Caddo. The Newsletter of the Friends of the Texas Archeological Research Laboratory 4(2):20-21.

Wilson, D. and T. K. Perttula

2013 Reconstructing the Diet of the Caddo through Stable Isotopes. American Antiquity 78(4):702-723.

Wilson, D. E., T. K. Perttula, and B. Nelson

2001 Human Skeletal Remains from 41CP25, the Peach Orchard Overlook Site, and their Archaeological Context. Journal of Northeast Texas Archaeology $14: 1-6$.

Wilson, D., T. K. Perttula, and M. Walters

2012 Stable Isotope Analysis from a Burial at the Pipe Site (41AN67) in Anderson County, Texas. Journal of Northeast Texas Archaeology 38:8591.

Wilson, D. and D. G. Steele

1996 Prehistoric Human Remains from 12 Sites at U.S. Army Corps of Engineers Reservoirs in Bell, Delta, Denton, Ellis, Hill, Marion, and Navarro Counties, Texas. Technical Reports No. 23. Prewitt and Associates, Inc., Austin.

1997 Appendix D: Analysis of Human Remains from Cooper Lake. In Synthesis of the Prehistoric and Historic Archaeology of Cooper Lake, Delta and Hopkins Counties, Texas, by R. C. Fields, M. E. Blake, and K. W. Kibler, pp. 177-244. Reports of Investigations No. 104. Prewitt and Associates, Inc., Austin.

Wilson, L.

1948 Two Small Pipes from the Sanders Site near Direct. The Record 6(7):30. Dallas Archeological Society, Dallas. 
Wilson, L. and R. Housewright

1941 Scrapers from Sanders Site, Lamar County. The Record 3(4):19-21. Dallas Archeological Society, Dallas.

Wilson, R.

1955 University of Oklahoma Summer Field Session at Broken Bow, Oklahoma. Oklahoma Anthropological Society Newsletter 4(3):6-7.

1962 The A. W. Davis Site, MC-6, of McCurtain County, Oklahoma. Bulletin of the Oklahoma Anthropological Society 10:103-152.

1963 Survey of the Archeological Resources of the Gillham Reservoir, Arkansas. The Arkansas Archeologist 4(9):1-5.

Winchell, $\mathrm{F}$.

1989 Comments on Caddo Settlement Patterns and Culture Identity. Caddoan Archeology Newsletter 1(1):7-13.

1990 An Assessment of the Fourche Maline Culture and its Place in the Prehistory of Northeast Texas. Caddoan Archeology Newsletter 1(4):7-19.

1993 A Look at the Relationship Between the Spiro and Toltec Centers on the Arkansas River: A View from the Ancient Nile Valley. Caddoan Archeology Newsletter 4(1):6-11.

Wisseman, S. U., T. E. Emerson, M. R. Hyne, and R. E. Hughes

2004 Using a Portable Spectrometer to Source Archaeological Materials and to Detect Restorations in Museum Objects. Journal of the American Institute for Conservation 43(2):129-138.

Wittry, W. L.

1952 The Preceramic Occupation of the Smith Site, Units I and II, Delaware County, Oklahoma. Master's thesis. Department of Anthropology, University of Wisconsin, Madison.

Wolfman, D.

1982 Archeomagnetic Dating in Arkansas and the Border Areas of Adjacent States. In Arkansas Archeology in Review, edited by N. L. Trubowitz and M. D. Jeter, pp. 277-300. Research Series No. 15. Arkansas Archeological Survey, Fayetteville.

1990 Archaeomagnetic Dating in Arkansas and the Border Areas of Adjacent States II. In Archaeomagnetic Dating, edited by J. L. Eighmy and R. S. Sternberg, pp. 237-260. University of Arizona Press, Tucson. 
Wood, W. R.

1961 The Denham Site, Mound I: An Interim Report on a Caddoan Site in Hot Springs County. Arkansas Archeological Survey Newsletter 2(10):1-6.

1962 The Crenshaw Site: A Coles Creek and Caddoan Mound Group in Miller County, Arkansas. University of Arkansas Museum, Fayetteville.

1963 The Speers Site 3GA2. The Arkansas Archeologist 4(2):12-13.

1963 The Denham Mound. A Mid-Ouachita Focus Temple Mound in Hot Springs County, Arkansas. Anthropology Series No. 1. University of Arkansas Museum, Fayetteville.

1963 A Preliminary Report on the 1962 Excavations at the Crenshaw Site3M16. In Arkansas Archeology, 1962, edited by C. R. McGimsey, III, pp. 1-14. Arkansas Archeological Society, Fayetteville.

1963 Two New Projectile Points: Homan and Agree. Arkansas Archeological Society Bulletin 4(2):1-6.

1966 Crenshaw Site. In Caddoan Area Field Reports, 1962-1964 Seasons, edited by H. A. Davis, pp. 1-2. University of Arkansas Museum, Fayetteville

1981 The Poole Site, 3GA3, With New Foreword and Summary by A. M. Early. The Arkansas Archeologist 22:7-65.

2011 A White-Bearded Plainsman: The Memoirs of Archaeologist W. Raymond Wood. University of Utah Press, Salt Lake City.

Wood, W. R. and R. E. Pangborn

1968 The Eureka and Comstock Mounds, Southwestern Missouri. Plains Anthropologist 13:1-17.

Woodall, J. N.

1967 The Harold Williams Site-A Preliminary Statement. Texas Archeology 1(4):7-10.

1969 Cultural Ecology of the Caddo. Ph.D. dissertation, Department of Anthropology, Southern Methodist University, Dallas.

1969 Archeological Excavations in the Toledo Bend Reservoir, 1966. Contributions in Anthropology No. 3. Department of Anthropology, Southern Methodist University, Dallas. 
1972 Prehistoric Social Boundaries: An Archeological Model and Test. Bulletin of the Texas Archeological Society 43:101-120.

1980 The Caddoan Confederacies-Some Ecological Considerations. Louisiana Archaeology 6:127-171.

Woolsey, A. M.

1935 Notes on Field Work, Solon Stanley Farm, 9 Miles Northeast Frankston, Cherokee County, November 5 and 6, 1935. MS on file, Texas Archeological Research Laboratory, The University of Texas at Austin.

1935 Notes on Field Work, Mrs. J. W. Blackburn Farm, 7 1/2 Miles Northwest of Jacksonville, Cherokee County, October 19, 1935 and October 30November 4, 1935. MS on file, Texas Archeological Research Laboratory, The University of Texas at Austin.

1935 Notes on Field Work, Ballard Estate, 7 1/2 Mi. south of Frankston, Anderson County, September 30, 1935. MS on file, Texas Archeological Research Laboratory, The University of Texas at Austin.

1935 Notes on Field Work, L. Cecil Farm, 2 1/2 Miles East of Frankston, Anderson County, October 11, 1935. MS on file, Texas Archeological Research Laboratory, The University of Texas at Austin.

1935 Notes on Field Work, Rube Beard Farm, 2 1/2 Miles South of Frankston, Anderson County, October 12, 1935. MS on file, Texas Archeological Research Laboratory, The University of Texas at Austin.

1935 Notes on Field Work De Long Farm [Stephenson Farm], 2 Miles Northwest Frankston, Anderson County, October 17, 1935. MS on file, Texas Archeological Research Laboratory, The University of Texas at Austin.

1935 Notes on Work Done, Henderson [Anderson] County, Texas, Mann Place, October 17, 1935. MS on file, Texas Archeological Research Laboratory, The University of Texas at Austin.

1935 Notes on Field Work, A. H. Reagor Farm, 1 Mile East of Old Larissa, 7 Miles Northwest Jacksonville, Cherokee County, November 4 and 5, 1935. MS on file, Texas Archeological Research Laboratory, The University of Texas at Austin.

1935 Burial Site, R. J. Fair Farm, 2 1/2 Miles Southwest of Jacksonville, Cherokee County, Texas, November 11 to November 16, 1935. MS on file, Texas Archeological Research Laboratory, The University of Texas at Austin.

1935 Notes on Field Work, E. W. Hackney Farm, 9 Miles Northwest Jacksonville, Cherokee County, November 16 to November 19, 1935. MS on file, Texas Archeological Research Laboratory, The University of Texas at Austin. 
1935 Notes on Field Work, E. W. Henry Farm, 7 Miles West of Jacksonville, Cherokee County, Texas. MS on file, Texas Archeological Research Laboratory, The University of Texas at Austin.

1935 Fred McKee Farm, 5 Miles Southeast Frankston, Anderson County, November 25 to November 27, 1935. MS on file, Texas Archeological Research Laboratory, The University of Texas at Austin.

1935 Notes on Field Work Omer and Otis Hood Farm, 4 1/2 Miles Northwest Jacksonville, Cherokee County, November 28 to December 7, 1935, Sites No. 1 and 2. MS on file, Texas Archeological Research Laboratory, The University of Texas at Austin.

1935 Notes on Work Done-Anderson County, Texas, Isibel-Gene Donnell Farm, October 14-16, 1935. MS on file, Texas Archeological Research Laboratory, The University of Texas at Austin.

1935 Notes on Field Work, Jasper Tucker Farm, Mrs. Joe Watkins Owner, 9 Miles Southwest of Frankston, Anderson County, November 20 to November 22, 1935. MS on file, Texas Archeological Research Laboratory, The University of Texas at Austin.

1935 Notes on Field Work, Jim P. Allen Farm 7 1⁄2 Miles Northwest Jacksonville, Cherokee County, October 19-November 4, 1935. MS on file, Texas Archeological Research Laboratory, The University of Texas at Austin.

Wormser, A. J.

1991 Test Excavations at the Jodie Bender Site, 41HS11, Harrison County, Texas. Texas State Department of Highways and Public Transportation, Highway Design Division, Austin.

Wormser, A. J. and S. S. Strickland

2003 Archeological Investigations at Site 41WD468/41WD469 Along SH 182 at Lake Fork Creek, Wood County, Texas. Report No. 47. Archeological Studies Program, Environmental Affairs Division, Texas Department of Transportation, Austin.

Wright, K. and M. B. Trubitt

2001 Recent Excavations in Saline and Montgomery Counties. Field Notes (Newsletter of the Arkansas Archeological Society) 300:10.

Wyckoff, D. G.

1961 Broken Bow Reservoir Survey. Oklahoma Anthropological Society Newsletter 9(8):8-9.

1962 Salvage Work in the Markham Ferry Reservoir Area. Oklahoma Anthropological Society Newsletter 19(8):2-3.

1963 Continued Salvage Work in Markham Ferry Reservoir. Oklahoma Anthropological Society Newsletter 11(5):2-3. 
1963 Archaeological Survey of the Pine Creek Reservoir, McCurtain County, Oklahoma. General Survey Report 3. Oklahoma River Basin Survey, University of Oklahoma Research Institute, Norman.

1964 The Jug Hill Site, My-18, Mayes County, Oklahoma. Bulletin of the Oklahoma Anthropological Society 12:1-53.

1964 Two Radiocarbon Dates from the Jug Hill Site, Mayes County, Oklahoma. Oklahoma Anthropological Society Newsletter 12(9):5-7.

1964 Two Radiocarbon Dates from the Markham Ferry Reservoir Area. Oklahoma Anthropological Society Newsletter 12(8):2-3.

1965 The Biggham Creek Site of McCurtain County, Oklahoma. Archaeological Site Report No. 3. Oklahoma River Basin Survey Project, University of Oklahoma, Norman.

1966 The Hughes, Lamas Branch, and Callaham Sites, McCurtain County, Oklahoma. Archaeological Site Report No. 4. Oklahoma River Basin Survey Project, University of Oklahoma, Norman.

1967 The E. Johnson Site and Prehistory in Southeast Oklahoma. Archaeological Site Report No. 6. Oklahoma River Basin Survey Project, University of Oklahoma, Norman.

1967 The Archaeological Sequence in the Broken Bow Reservoir Area, McCurtain County, Oklahoma. University of Oklahoma Research Institute, Norman.

1967 Woods Mound Group: A Prehistoric Mound Complex in McCurtain County, Oklahoma. Bulletin of the Oklahoma Anthropological Society 15:1-76.

1967 Recent Salvage Excavations in Eastern Oklahoma. Plains Anthropologist 12(36):215.

1968 The Beaver Site and the Archaeology of the Broken Bow Reservoir Area, McCurtain County, Oklahoma. Archaeological Site Report No. 9. Oklahoma River Basin Survey Project, University of Oklahoma, Norman.

1968 The Bell and Gregory Sites: Archaeological Chronicles of Prehistory in the Pine Creek Reservoir Area, Southeast Oklahoma. Archaeological Site Report No. 11. Oklahoma River Basin Survey Project, University of Oklahoma, Norman. 
1969 New Radiocarbon Dates from the Arkansas River Valley, Eastern Oklahoma. Oklahoma Anthropological Society Newsletter 17(2):6-7.

1970 The Horton Site Revisited, 1967 Excavations at Sq-11, Sequoyah County, Oklahoma. Studies in Oklahoma's Past No. 1. Oklahoma Archeological Survey, Norman.

1970 Archaeological and Historical Assessment of the Red River Basin in Oklahoma. In Archeological and Historical Resources of the Red River Basin, Louisiana, Texas, Oklahoma, Arkansas, edited by H. A. Davis, pp. 69-134. Research Series No. 1. Arkansas Archeological Survey, Fayetteville.

1970 A Preliminary Report on 1970 Field Research at the Spiro Site, LeFlore County, Oklahoma. Oklahoma Archeological Survey, Norman.

1973 The Lowrance Site of Murray County: 1969 Excavations by the Oklahoma Anthropological Society. Oklahoma Anthropological Society Bulletin 21:1155.

1974 The Caddoan Cultural Area: An Archeological Perspective. In Caddoan Indians I, pp. 25-280. Garland Publishing, New York.

19761976 Archaeological Field Work at the McCutchan-McLaughlin Site, Latimer County, Oklahoma. Oklahoma Anthropological Society Newsletter 24(8):1-9.

1979 Dating the Prehistoric Habitation of the McCutchan-McLaughlin Site, Lt11, Latimer County, Oklahoma. Oklahoma Anthropological Society Newsletter 27(2):7-8.

1980 Caddoan Adaptive Strategies in the Arkansas Basin of Eastern Oklahoma. Ph.D. dissertation, Department of Anthropology, Washington State University, Pullman.

1985 Images on Shell: Spiro Symbolism and Ceremonial Art. Reviews in Anthropology 12:329-337.

1985 Notes on Some Hoes Found in Oklahoma. Oklahoma Anthropological Society Newsletter 33(3):6-7.

1989 Animal Remains from the 1982 Excavations: Spiroan Hunters and Their Prey. In Contributions to Spiro Archaeology: Mound Excavations and Regional Perspectives, edited by J. D. Rogers, D. G. Wyckoff, and D. A. Peterson, pp. 89-100. Studies in Oklahoma's Past No. 16. Oklahoma Archeological Survey, Norman. 
2001 Spiro: Native American Trade a Millennium Ago. Gilcrease Journal 9(2):48-63.

2008 To Be or Not To Be, Axe is the Question. Oklahoma Archeology 56(3):1014.

2010 Hunter-Gatherer Chert Use along the Southwest Flank of the Ozarks. The Missouri Archaeologist 71:79-112.

2013 Review of "The Archaeology of the Caddo." American Antiquity 78(1):198199.

Wyckoff, D. G. and T. G. Baugh

1980 Early Historic Hasinai Elites: A Model for the Material Culture of Governing Elites. Midcontinental Journal of Archaeology 5:225-283.

Wyckoff, D. G. and T. P. Barr

19641963 Archaeological Activity in the Markham Ferry Reservoir Area, Mayes County, Oklahoma. General Survey Report No. 4. Oklahoma River Basin Survey Project, University of Oklahoma Research Institute, Norman.

1967 The McCulley Site: A Preceramic Site in the Webbers Falls Lock and Dam Area, Muskogee County, Oklahoma. Archaeological Site Report No. 8. Oklahoma River Basin Survey, University of Oklahoma Research Institute, Norman.

1967 The Cat Smith Site: A Late Prehistoric Village in Muskogee County, Oklahoma. Bulletin of the Oklahoma Anthropological Society 15:81-106.

Wyckoff, D. G. and L. R. Fisher

1985 Preliminary Testing and Evaluation of the Grobin Davis Archeological Site, 34MC253, McCurtain County, Oklahoma. Archeological Resources Survey Report No. 22. Oklahoma Archeological Survey, Norman.

Wyckoff, D. G. and D. Peterson

1994 Spiro Mounds, Prehistoric Gateway....Present-Day Enigma. Oklahoma Museum of Natural History, Norman.

Wyckoff, D. G. and R. L. Brooks (editors)

1983 Oklahoma Archeology: A 1981 Perspective of the State's Archeological Resources, Their Significance, Their Problems, and Some Proposed Solutions. Archeological Resources Survey Report No. 16. Oklahoma Archeological Survey, Norman.

Wyckoff, D. G. and J. L. Hofman (editors) 
1983 Southeastern Natives and Their Pasts. Studies in Oklahoma's Past No. 11. Oklahoma Archeological Survey, Norman.

Wyckoff, D. G., P. Robison, and T. P. Barr

1963 Markham Ferry Reservoir Archeological Resources, Mayes County, Oklahoma. General Survey Report No. 1, Oklahoma River Basin Survey Project, University of Oklahoma Research Institute, Norman.

1963 The Kerr Dam Site: A Stratified Site in the Markham Ferry Reservoir Area, Mayes County, Oklahoma. Archaeological Site Report No. 1, Oklahoma River Basin Survey Project, University of Oklahoma Research Institute, Norman.

Wyckoff, D. G. and T. Van Woody

19771977 Field Work at LT11: Oklahoma Anthropological Society Spring Dig and the University Field School. Oklahoma Anthropological Society Newsletter 25(8):1-13.

Yedlowski, J. L., K. J. Shaunessy, D. H. Jurney, and J. M. Adovasio 1998 Archaeological Investigations in Support of the Superconducting Super Collider, Ellis County, Texas. Archaeology Research Program, Mercyhurst College, Erie, Pennsylvania.

York, H. P.

1996 Demography and Paleopathology of the Spiro Mound Burials of Southeastern Oklahoma. Master's thesis, Department of Anthropology, University of Oklahoma, Norman.

Young, W. C.

1981 Test Excavations at the Tankersky Creek Site, A Multicomponent Campsite in Titus County, Texas. Publications in Archeology Report No. 22. Texas State Department of Highways, Austin.

Youngblood, D.

2008 The Windfall/Shortfall Model: A Seasonal Theory of Crop Inclusion Based on Analysis of Woodlands Frontier Plant Remains. Plains Anthropologist 53(205):107-120.

Younger-Mertz, S. B., J. E. Manuel, T. Reinert, S. Z. Szilasi, S. W. Hammerstedt, and G. A. Glass

2015 Ion Beam Analysis of Microcrystalline Quartz Artifacts from the Reed Mound Site, Delaware County, Oklahoma. Physics Procedia 66:305-320.

Zahn, E. 
1985 A Social Analysis of the Mortuary Behavior of the Central Caddo in the Great Bend Region: A Regional Approach. Master's thesis, Department of Anthropology, University of Arkansas, Fayetteville.

1987 A Cultural Resources Survey of the Proposed Mena Transmission Main from Forks Reservoir, Polk County, Arkansas. Project Report No. 645. Arkansas Archeological Survey, Fayetteville. 


\section{CADDO ETHNOHISTORY \& ETHNOGRAPHY}

Barr, J.

1999 The "Seductions" of Texas: The Political Language of Gender in the Conquests of Texas, 1690-1803. Ph.D. dissertation, Department of History, University of Wisconsin, Madison.

2004 A Diplomacy of Gender: Rituals of First Contact in the 'Land of the Tejas.' William and Mary Quarterly 61:393-434.

2005 Beyond Their Control: Spaniards in Native Texas. In Choice, Persuasion, and Coercion: Social Control in Spain's North American Frontier, edited by J. F. de la Teja and R. Frank. University of New Mexico Press, Albuquerque.

2005 From Captives to Slaves: Commodifying Indian Women in the Borderlands. Journal of American History 92:19-46.

2007 Peace Came in the Form of a Woman: Indians and Spaniards in the Texas Borderlands. University of North Carolina Press, Chapel Hill.

2011 Geographies of Power: Mapping Indian Borders in the "Borderlands" of the Early Southwest. William and Mary Quarterly 68(1):5-46.

2015 Native Americans. In La Belle: The Ship that Changed History, edited by J. E. Bruseth, pp. 36-41. Bullock Texas State History Museum and Texas A\&M University Press, Austin and College Station.

2017 There's No Such Thing as "Prehistory": What the Longue Duree of Caddo and Pueblo History Tells Us about Colonial America. The William and Mary Quarterly 74(2):203-240.

Berlandier, J. L.

1969 The Indians of Texas in 1830. Edited by J. C. Ewers. Smithsonian Institution Press, Washington, D.C.

Blake, L. W.

1981 Early Acceptance of Watermelon by Indians of the United States. Journal of Ethnobiology 1:192-199.

Bobb, A.

1937 Burial Customs of the Caddoes. In Indians at Work, p. 40. A News Sheet for Indians and the Indian Service, Office of Indian Affairs, Washington, D.C.

Bolton, H. E. 
1987 The Hasinais: Southern Caddoans as seen by the Earliest Europeans. University of Oklahoma Press, Norman.

Brown, C. H.

2006 Glottochronology and the Chronology of Maize in the Americas. In Histories of Maize: Multidisciplinary Approaches to the Prehistory, Linguistics, Biogeography, Domestication, and Evolution of Maize, edited by J. Staller, R. Tykot, and B. Benz, pp. 647-664. Academic Press, Burlington, Massachusetts.

Brown, C. H., S. Wichmann, and D. Beck

2014 Chitimacha: A Mesoamerican Language in the Lower Mississippi Valley. International Journal of American Linguistics 80(4):425-474.

Brown, C. H., E. Luedeling, S. Wichmann, and P. Epps

2013 The Paleobiolinguistics of Domesticated Squash (Cucurbita spp.). In Explorations in Ethnobiology: The Legacy of Amadeo Rea, edited by M. Quinlan and D. Lepofsky, pp. 132-161. Society of Ethnobiology, Denton.

Bushnell, D. L., Jr.

1922 Villages of the Algonquian, Siouan, and Caddoan Tribes West of the Mississippi. Bulletin No. 77. Bureau of American Ethnology, Smithsonian Institution, Washington, D.C.

Campbell, T. N.

1996 Anadarko Indians. In The New Handbook of Texas, Vol. 1, edited by R. Tyler, p. 158. Texas State Historical Association, Austin.

1996 Cachae Indians. In The New Handbook of Texas, Vol. 1, edited by R. Tyler, p. 884. Texas State Historical Association, Austin.

1996 Canonizochitoui Indians. In The New Handbook of Texas, Vol. 1, edited by R. Tyler, p. 961. Texas State Historical Association, Austin.

1996 Caso Indians. In The New Handbook of Texas, Vol. 1, edited by R. Tyler, p. 1012. Texas State Historical Association, Austin.

1996 Caxo Indians. In The New Handbook of Texas, Vol. 1, edited by R. Tyler, p. 1050. Texas State Historical Association, Austin.

1996 Cataye Indians. In The New Handbook of Texas, Vol. 1, edited by R. Tyler, p. 1025. Texas State Historical Association, Austin.

1996 Chaquantie Indians. In The New Handbook of Texas, Vol. 2, edited by R. Tyler, pp. 47-48. Texas State Historical Association, Austin. 
1996 Dotchetonne Indians. In The New Handbook of Texas, Vol. 2, edited by R. Tyler, p. 682. Texas State Historical Association, Austin.

1996 Hacanac Indians. In The New Handbook of Texas, Vol. 3, edited by R. Tyler, p. 398. Texas State Historical Association, Austin.

1996 Lacane Indians. In The New Handbook of Texas, Vol. 3, edited by R. Tyler, p. 1185. Texas State Historical Association, Austin.

1996 Naansi Indians. In The New Handbook of Texas, Vol. 4, edited by R. Tyler, p. 921. Texas State Historical Association, Austin.

1996 Nabeyxa Indians. In The New Handbook of Texas, Vol. 4, edited by R. Tyler, pp. 921-922. Texas State Historical Association, Austin.

1996 Nabiri Indians. In The New Handbook of Texas, Vol. 4, edited by R. Tyler, p. 922. Texas State Historical Association, Austin.

1996 Nacachau Indians. In The New Handbook of Texas, Vol. 4, edited by R. Tyler, p. 922. Texas State Historical Association, Austin.

1996 Nacaniche Indians. In The New Handbook of Texas, Vol. 4, edited by R. Tyler, p. 922. Texas State Historical Association, Austin.

1996 Nacau Indians. In The New Handbook of Texas, Vol. 4, edited by R. Tyler, p. 922. Texas State Historical Association, Austin.

1996 Nacogdoche Indians. In The New Handbook of Texas, Vol. 4, edited by R. Tyler, p. 923. Texas State Historical Association, Austin.

1996 Nacono Indians. In The New Handbook of Texas, Vol. 4, edited by R. Tyler, pp. 930-931. Texas State Historical Association, Austin.

1996 Nanatsoho Indians. In The New Handbook of Texas, Vol. 4, edited by R. Tyler, p. 933. Texas State Historical Association, Austin.

1996 Nasayaha Indians. In The New Handbook of Texas, Vol. 4, edited by R. Tyler, p. 937. Texas State Historical Association, Austin.

1996 Nasoni Indians. In The New Handbook of Texas, Vol. 4, edited by R. Tyler, pp. 938-939. Texas State Historical Association, Austin.

1996 Natchitoch Indians. In The New Handbook of Texas, Vol. 4, edited by R. Tyler, p. 940. Texas State Historical Association, Austin. 
1996 Nechaui Indians. In The New Handbook of Texas, Vol. 4, edited by R. Tyler, p. 965. Texas State Historical Association, Austin.

1996 Neche Indians. In The New Handbook of Texas, Vol. 4, edited by R. Tyler, p. 965. Texas State Historical Association, Austin.

1996 Palaquesson Indians. In The New Handbook of Texas, Vol. 5, edited by R. Tyler, p. 21. Texas State Historical Association, Austin.

1996 Tadiva Indians. In The New Handbook of Texas, Vol. 6, edited by R. Tyler, p. 191. Texas State Historical Association, Austin.

1996 Vinta Indians. In The New Handbook of Texas, Vol. 6, edited by R. Tyler, p. 759. Texas State Historical Association, Austin.

Campbell, T. N. and T. J. Campbell

1985 Indian Groups Associated with Spanish Missions of the San Antonio Missions National Historical Park. Special Report 16. Center for Archaeological Research, The University of Texas at San Antonio.

Carson, J. T.

1995 Horses and the Economy and Culture of the Choctaw Indians, 1690-1840. Ethnohistory 42(3):495-513.

Carter, C. E.

2010 Caddo Nation. The Encyclopedia of Arkansas History \& Culture, http://www.encyclopediaofarkansas.net/encyclopedia/entrydetail.aspx?entry|D=549.

Cast, R.

2014 Peyoteism and the Origins of Caddo Religious Thought. Caddo Archeology Journal 24:167-168.

Castaneda, C. E.

1931 Myths and Customs of the Tejas Indians. Publications of the Texas Folklore Society 9:167-174.

Chafe, W.

1968 The Ordering of Phonological Rules. International Journal of American Linguistics 34:115-136.

1973 Siouan, Iroquoian, and Caddoan. In "Current Trends in Linguistics," edited by T. A. Sebeok. Linguistics in North America 10:1164-1209.

1976 The Caddoan, Iroquoian, and Siouan Languages. Mouton, The Hague. 
1976 Siouan, Iroquoian, and Caddoan. In Native Languages of the Americas, edited by T. A. Sebeok, pp. 527-572. Plenum Press, New York.

1977 Caddo Texts. In Caddoan Texts, edited by D. R. Parks, pp. 27-43. International Journal of American Linguistics, Native American Text Series 2, No. 1.

1979 Caddoan. In Languages of Native North America: A Historical and Comparative Assessment, edited by L. Campbell and M. Mithun, pp. 213235. University of Texas Press, Austin.

1983 The Caddo Language, Its Relatives, and Its Neighbors. In North American Indians: Humanistic Perspectives, edited by J. S. Thayer, pp. 243-250. Papers in Anthropology 24(2). Department of Anthropology, University of Oklahoma, Norman.

1990 Use of the Defocusing Pronominal Prefixes in Caddo. Anthropological Linguistics 32:57-68.

1993 Caddo Names in the de Soto Documents. In The Expedition of Hernando de Soto West of the Mississippi, 1541-1543: Proceedings of the De Soto Symposia, 1988 and 1990, edited by G. A. Young and M. P. Hoffman, pp. 222-226. University of Arkansas Press, Fayetteville.

1995 The Realis-Irrealis Distinction in Caddo, the Northern Iroquoian Languages, and English. In Modality in Grammar and Discourse, edited by J. Bybee and S. Fleischman, pp. 349-365. John Benjamins, Amsterdam and Philadephia.

1995 A Note on the Caddo Language. In Caddo Indians: Where We Come From, by C. E. Carter, pp. 1-2. University of Oklahoma Press, Norman.

1997 Introduction to the Paperback Edition of Traditions of the Caddo, by G. A. Dorsey, pp. vii-xxiv. University of Nebraska Press, Lincoln.

2005 Caddo. In The Native Languages of the Southeastern United States, edited by H. K. Hardy and J. Scancarelli, pp. 323-350. University of Nebraska Press, Lincoln.

2005 Tsa Ch'ayah: How the Turtle Got Its Squares: A Traditional Caddo Indian Children's Story. Xlibris Corporation, Philadephia.

2007 Caddo. In The New Encyclopedia of Southern Culture, pp. 47-48. University of North Carolina Press, Chapel Hill. 
2010 The History and Geography of the Caddo Language. In Language Variety in the South (LAVIS) III. University of Alabama Press, Tuscaloosa.

2015 A Profile of the Caddo Language. In New Perspectives on Language Variety in the South: Historical and Contemporary Approaches, edited by M. D. Picone and C. E. Davies, pp. 43-51. University of Alabama Press, Tuscaloosa.

Claiborne, J. F. H. and O. T. Mason

1879 Anthropological News. American Naturalist 13:788-790.

Corbin, J. E.

1989 Spanish-Indian Interaction on the Eastern Frontier of Texas. In Columbian Consequences, Vol. 1, Archaeological and Historical Perspectives on the Spanish Borderlands West, edited by D. H. Thomas, pp. 269-276. Smithsonian Institution Press, Washington, D.C.

Cunningham, D. S. (editor)

2006 The Domingo Ramon Diary of the 1716 Expedition into the Province of the Tejas Indians: An Annotated Translation. Southwestern Historical Quarterly 110(1):39-67.

2007 Father Isidro Felix de Espinosa's Diary of the New Entry into the Province of the Tejas, Year 1716: An Annotated Translation. Catholic Southwest 18:9-35.

Da Cruz, D.

1957 A revised Analysis of Segmental Phonemes in Caddo. Senior essay, Department of Linguistics, Georgetwon University, Washington, D.C.

Deter-Wolf, A.

2013 Needle in a Haystack: Examining the Archaeological Evidence for Prehistoric Tattoing. In Drawing with Great Needles: Ancient Tattoo Traditions of North America, edited by A. Deter-Wolf and C. DiazGranados, pp. 43-72. University of Texas Press, Austin.

Dickinson, S. D.

1980 Historic Tribes of the Ouachita Drainage System in Arkansas. The Arkansas Archeologist 21:1-11.

1986 The River of Cayas, The Ouachita or the Arkansas River? Arkansas Archeological Society Field Notes 209:5-11.

Doolittle, W. E.

2000 Cultivated Landscapes of Native North America. Oxford University Press, Oxford. 
Dorsey, G. A.

1905 Caddo Customs of Childhood. Journal of American Folk Lore 18:226-228.

1905 Traditions of the Caddo. Publication No. 41. Carnegie Institution of Washington, Washington, D.C. Reprinted 1997 by University of Nebraska Press, Lincoln.

Douglas, F. H.

1932 The Grass House of the Wichita and Caddo. Department of Indian Art Leaflet 42. Denver Art Museum, Denver, Colorado.

Early, A. M.

2000 The Caddos of the Trans-Mississippi South. In Indians of the Greater Southeast, edited by B. G. McEwan, pp. 122-141. University Press of Florida, Gainesville.

2000 Review of "The Caddo Chiefdoms: Caddo Economics and Politics, 7001835," by D. La Vere. Arkansas Historical Quarterly 58(3):331-332.

Edwards, R. J.

1972 Plaintiff's Caddo Tribe of Oklahoma, et al Requested Findings of Fact and Brief on Title (Counts II and IV of Amended Complaint). Before the Indian Claims Commission, Docket No. 226.

Ewers, J. C.

1955 The Horse in Blackfoot Indian Culture, with Comparative Material from Other Western Tribes. Bulletin No. 159. Bureau of American Ethnology, Smithsonian Institution, Washington, D.C.

1973 The Influence of Epidemics on the Indian Populations and Cultures of Texas. Plains Anthropologist 18(60):104-115.

1974 Symbols of Chiefly Authority in Spanish Louisiana. In The Spanish in the Mississippi Valley, edited by J. McDermott, pp. 272-286. University of Illinois Press, Urbana.

Fletcher, A. C.

1907 Caddo. In Handbook of American Indians North of Mexico, edited by F. W. Hodges, pp. 179-183. Bulletin 30. Bureau of American Ethnology, Smithsonian Institution, Washington, D.C.

1907 Kadohadacho. In Handbook of American Indians North of Mexico, edited by F. W. Hodges, pp. 638-639. Bulletin 30. Bureau of American Ethnology, Smithsonian Institution, Washington, D.C. 
Galan, R. B.

1994 Caddo Mythology: Ethnohistorical and Archaeological Considerations. Mid-American Folklore 22(2):61-67.

Gallatin, A.

1836 A Synopsis of the Indian Tribes of North America. American Antiquarian Society 2:116.

Gatschet, A. S.

1880 Linguistic Notes. The American Antiquarian 2(3):236-238.

Gelo, D. J.

2012 Indians of the Great Plains. Pearson Education, Inc., Boston.

Gerona, C.

2012 Caddo Sun Accounts across Time and Place. American Indian Quarterly 36(3):348-376.

Gilmore, K.

1996 Early European-Indian Ceremonies on the Red River. Journal of Northeast Texas Archaeology 7:1-2.

Gleason, M.

1981 Caddo: A Survey of the Caddo Indian in Northeast Texas and Marion County; 1541-1840. Marion County Historical Commission, Jefferson.

Goldberg, M. A.

2009 Negotiating Nacogdoches: Hasinai Caddo-Spanish Relations, Trade Space, and the Formation of the Texas-Louisiana Border, 1779-1819. American Indian Culture and Research Journal 33(1):65-87.

Gray, M. P. and W. S. Laughlin

1960 Blood Groups of Caddoan Indians of Oklahoma. American Journal of Human Genetics 12(1):86-94.

Gregort, H. F.

2016 An Ethnography and Indo-Hispanic Lexicon from Sabine and Natchitoches Parishes, Louisiana. Lower Mississippi River Delta Initiative, National Park Service, U. S. Department of the Interior, and Creole Heritage Center, Northwestern State University of Louisiana, Natchitoches.

Gregory, H. F. (editor)

1986 The Southern Caddo: An Anthology. Garland Publishing, New York.

Griffith, W. J. 
1954 The Hasinai Indians of East Texas as Seen by Europeans, 1687-1772. Philological and Documentary Studies, Vol. 2, No. 3. Middle American Research Institute, Tulane University, New Orleans.

Harby, L. C.

1894 The Tejas: Their Habits, Government, and Superstition. Annual Report of the American Historical Association (1894):63-82.

Hatcher, M. A.

1927 Descriptions of the Tejas or Asinai Indians, 1691-1722. Southwestern Historical Quarterly 30-31.

1927 Myths of the Tejas Indians. Publications of the Texas Folklore Society 4:107-118.

Hawkins, S.

2013 An autumn tale of the people of the Caddo. Trowel Marks (The Oklahoma Anthropological Society Quarterly News) 5(2):14.

Heflin, E.

1953 The Oashuns or Dances of the Caddo. Bulletin of the Oklahoma Anthropological Society 1:39-42.

Hickerson, D. A.

1992 Early Historic Hasinai Leadership: Toward a Coalition Theory. Caddoan Archeology Newsletter 3(2):1-11.

1995 Historical Processes and the Political Organization of the Hasinai Caddo Indians. Caddoan Archeology Newsletter 6(3):5-15.

1996 Hasinai-European Interaction, 1694-1715. East Texas Historical Journal 34:3-16.

1996 Trade, Mediation, and Political Status in the Hasinai Confederacy. Research in Economic Anthropology 17:149-168.

1997 Historical Processes, Epidemic Diseases, and the Formation of the Hasinai Confederacy. Ethnohistory 44(1):31-52.

Hoffman, M. P.

1984 Historic Indians of Arkansas. The Arkansas Naturalist 2(10):1-14.

1993 Identification of Ethnic Groups Contacted by the de Soto Expedition in Arkansas. In The Expedition of Hernando de Soto West of the Mississippi, 1541-1543: Proceedings of the De Soto Symposia, 1988 and 1990, edited 
by G. A. Young and M. P. Hoffman, pp. 132-142. University of Arkansas Press, Fayetteville.

Hudson, C.

1993 Reconstructing the de Soto Expedition Route West of the Mississippi River: Summary and Contents. In The Expedition of Hernando de Soto West of the Mississippi, 1541-1543: Proceedings of the De Soto Symposia, 1988 and 1990, edited by G. A Young and M. P. Hoffman, pp. 143-154. University of Arkansas Press, Fayetteville.

1997 Knights of Spain, Warriors of the Sun. University of Georgia Press, Athens.

Kelley, J. C.

1955 Juan Sabeata and Diffusion in Aboriginal Texas. American Anthropologist 57:981-995.

Kenmotsu, N. A. and J. W. Arnn III

2012 The Toyah Phase and the Ethnohistorical Record. In The Toyah Phase of Central Texas: late Prehistoric Economic and Social Processes, edited by N. A. Kenmotsu and D. K. Boyd, pp. 19-43. Texas A\&M University Press, College Station.

Kenmotsu, N. A. and T. K. Perttula

1996 "Historical Processes and the Political Organization of the Hasinai Caddo Indians:" A Reply. Caddoan Archeology 7(2):9-24.

Kenmotsu, N. A., J. E. Bruseth, and J. E. Corbin

1993 Moscoso and the Route in Texas: A Reconstruction. In The Hernando de Soto Expedition West of the Mississippi, 1541-1543: Proceedings of the De Soto Symposia, 1988 and 1990, edited by G. A. Young and M. P. Hoffman, pp. 106-131. University of Arkansas Press, Fayetteville.

Kenney, M. M.

1897 Tribal Society among the Tejas Indians. Texas State Historical Association Quarterly 1:26-33.

Kidder, T. R.

1990 The Ouachita Indians of Louisiana: An Ethnohistorical and Archaeological Investigation. Louisiana Archaeology 12:179-202.

Kniffen, E. B.

1935 The Historic Indian Tribes of Louisiana. Louisiana Conservation Review $4(7): 5-12$.

1965 The Indians of Louisiana. Louisiana State University Press, Baton Rouge. 
1975 Louisiana's Historic Indians. Louisiana Archaeology 2:1-22.

Kniffen, E. B., H. F. Gregory, and G. A. Stokes

1987 The Historic Indian Tribes of Louisiana From 1542 to the Present. Louisiana State University Press, Baton Rouge.

Krech, S. III

2009 Spirits of the Air: Birds and American Indians in the South. University of Georgia Press, Athens.

Krieger, M. H.

1996 Amediche Indians. In The New Handbook of Texas, Vol. 1, edited by R. Tyler, p. 145. Texas State Historical Association, Austin.

1996 Nabedache Indians. In The New Handbook of Texas, Vol. 4, edited by R. Tyler, p. 921. Texas State Historical Association, Austin.

Kunkel, P. A.

1951 The Indians of Louisiana, About 1700-Their Customs and Manner of Living. Louisiana Historical Quarterly 34(3):175-203.

La Vere, D. L.

1993 Strangers for Family: Gifts, Reciprocity, and Kinship in CaddoanEuroamerican Relations. Ph.D. dissertation, Department of History, Texas A\&M University, College Station.

1998 Kinship and Capitalism: French and Spanish Rivalry in the Colonial Louisiana-Texas Indian Trade. Journal of Southern History 64(2):197-218.

1998 Life Among the Texas Indians: The WPA Narratives. Texas A\&M University Press, College Station.

1998 The Caddo Chiefdoms. Caddo Economics and Politics, 700-1835. University of Nebraska Press, Lincoln.

Lee, D. B.

1988 Trait Continua in Historic Caddo Burials. Louisiana Folklife Journal 12.

1998 A Social History of Caddoan Peoples: Cultural Adaptation and Persistence in a Native American Community. Ph.D. dissertation, Department of Anthropology, University of Oklahoma, Norman.

2004 Evidence of Dual Organization in Southern Caddo Expressive Culture. Louisiana Folklife Journal 28. 
Lesser, A.

1979 Caddoan Kinship Systems. Nebraska History 60(2):260-271.

Lesser, A. and G. Weltfish

1932 Composition of the Caddoan Linguistic Stock. Miscellaneous Collections 87(6). Smithsonian Institution, Washington, D.C.

Magnaghi, R. M.

1981 Changing Material Culture and the Hasinais of East Texas. Southern Studies 20.

1996 Hasinai Indians. In The New Handbook of Texas, Vol. 3, edited by R. Tyler, pp. 499-500.

Marceaux, P. S.

2005 Caddo Archives and Economies. Caddoan Archeology Journal 14:79-91.

Marcy, R. B.

1855 Specimens of the Caddo and Wichita Languages. In Historical and Statistical Information Respecting the History Condition, and Prospects of the Indian Tribes of the United States, edited by H. R. Schoolcraft, pp. 709-712. Part 5. Lippincott, Grambo and Company, Philadelphia.

Meadows, W. C.

2013 Kiowa Ethnonymy of Other Populations. Plains Anthropologist 58(226):530.

Medford, C., Jr., H. F. Gregory, D. Sepulvado, N. Cameron, and J. Jones 1990 The Old Ways Live: The Claude Medford Jr. Collection. Williamson Museum, Northwestern State University, Natchitoches.

Melnar, L. R.

1996 Caddo Verb-Stem Locatives. 1994 Mid-America Linguistics Conference Papers 2:598-610.

2004 Caddo Verb Morphology. University of Nebraska Press, Lincoln.

Miller, J.

1996 Changing Moons: A History of Caddo Religion. Plains Anthropologist 41(157):243-259.

2015 Ancestral Mounds: Vitality and Votality of Native America. University of Nebraska Press, Lincoln.

2015 Allied Mounds: Touching the Earth, Modeling the World, Reaching the Sky. Self-published, San Bernardino, California. 
Mithun, M.

1999 The Languages of Native North America. Cambridge University Press, Cambridge.

Mooney, J.

1896 The Ghost Dance Religion, and the Sioux Outbreak of 1890. Fourteenth Annual Report of the Bureau of Ethnology, 1892-1893, Part 2. Bureau of Ethnology, Smithsonian Institution, Washington, D.C. Reprinted 1991 by University of Nebraska Press, Lincoln.

Neighbours, K. F.

1966 Jose Maria: Anadarko Chief. Chronicles of Oklahoma 44:254-274.

Newcomb, W. W., Jr.

1958 Indian Tribes of Texas. Bulletin of the Texas Archeological Society 29:134.

1961 The Indians of Texas from Prehistoric to Modern Times. University of Texas Press, Austin.

Newkumet, V. B. and H. L. Meredith

1988 Hasinai: A Traditional History of the Caddo Confederacy. Texas A\&M University Press, College Station.

1988 Into the Light: Origins of the Hasinai People. Chronicles of Oklahoma 66(3):282-293.

Odell, G.

2002 La Harpe's Post: A Tale of French-Wichita Contact on the Eastern Plains. The University of Alabama Press, Tuscaloosa.

Padilla, J. A.

1919 Texas in 1820: Report on the Barbarous Indians of the Province of Texas. Translated by M. A. Hatcher. Southwestern Historical Quarterly 23:47-68.

Parks, D. R. (editor)

1977 Caddoan Texts. International Journal of American Linguistics, Native American Texts, 2nd Series, No. 1.

Parsons, E. C.

1941 Notes on the Caddo. Memoir 57. American Anthropological Association, Washington, D.C.

Perttula, T. K. 
1994 French and Spanish Colonial Trade Policies and the Fur Trade among the Caddoan Indians of the Trans-Mississippi South. In The Fur Trade Revisited: Selected Papers of the Sixth North American Fur Trade Conference, Mackinac Island, Michigan, 1991, edited by S. H. Brown, W J. Eccles, and D. P. Heldman, pp. 71-91. Michigan State University Press, Lansing.

1996 Caddo Indians. In The New Handbook of Texas, Vol. 1, edited by R. Tyler, pp. 887-888. Texas State Historical Association, Austin.

Rogers, J. D. and G. Sabo III

2004 The Caddos. In Handbook of North American Indians, Volume 14, Southeast, edited by R. D. Fogelson, pp. 616-631. Smithsonian Institution, Washington, D.C.

Rollings, W. H.

1992 The Osage: An Ethnohistorical Study of Hegemony on the Prairie-Plains. University of Missouri Press, Columbia.

Sabo, G., III

1987 Reordering their World: A Caddoan Ethnohistory In Visions and Revisions: Ethnohistoric Perspectives on Southern Cultures, edited by G. Sabo, III and W. M. Schneider, pp. 7-27. University of Georgia Press, Athens.

1992 Paths of Our Children: Historic Indians of Arkansas. Popular Series No. 3. Arkansas Archeological Survey, Fayetteville.

1992 Encounters and Exchanges: French, Spanish, and Caddo Indian Interaction in the 17th and 18th Centuries. In Transferts Culturels en Amerique et Ailleurs, edited by L. Turgeon, D. Delage, abd R. Quellet, pp. 467-488. Musee de la Civilisation, Quebec, Canada.

1993 Indians and Spaniards in Arkansas: Symbolic Action in the Sixteenth Century. In The Hernando de Soto Expedition West of the Mississippi, 1541-1543: Proceedings of the De Soto Symposia, 1988 and 1990, edited by G. A. Young and M. P. Hoffman, pp. 192-209. University of Arkansas Press, Fayetteville.

1995 Rituals of Encounter: Interpreting Native American Views of European Explorers. In Cultural Encounters in the Early South: Indians and Europeans in Arkansas, compiled by J. Whayne, pp. 76-87. University of Arkansas Press, Fayetteville.

1995 Encounters and Images: European Contact and Caddo Indians. Historical Reflections/Reflexions Historique 21(2):217-242. 
1998 The Structure of Caddo Leadership in the Colonial Era. In The Native History of the Caddo: Their Place in Southeastern Archeology and Ethnohistory, edited by T. K. Perttula and J. E. Bruseth, pp. 159-174. Studies in Archeology 30. Texas Archeological Research Laboratory. The University of Texas at Austin.

2001 Paths of Our Children: Historic Indians of Arkansas. Revised ed. Popular Series 3. Arkansas Archeological Survey, Fayetteville.

2003 Dancing into the Past: Colonial Legacies in Modern Caddo Indian Ceremony. Arkansas Historical Quarterly 62(4):423-445.

2012 The Teran Map and Caddo Cosmology. In The Archaeology of the Caddo, edited by T. K. Perttula and C. P. Walker, pp. 431-447. University of Nebraska Press, Lincoln.

Schambach, F. F.

1993 The End of the Trail: Reconstruction of the Route of Hernando de Soto's Army through Southwest Arkansas and East Texas. In The Expedition of Hernando de Soto West of the Mississippi, 1541-1543. Proceedings of the de Soto Symposia, 1988 and 1990, edited by G. A. Young and M. P. Hoffman, pp. 78-105. University of Arkansas Press, Fayetteville.

Schoolcraft, H. R.

1853 Information Respecting the History, Condition, and Prospects of the Indian Tribes of the United States. Lippincott, Grambo, Philadelphia.

Shuck-Hall, S. M.

2008 Journey to the West: The Alabama and Coushatta Indians. University of Oklahoma Press, Norman.

Sibley, J.

1832 Historical Sketches of Several Indian Tribes in Louisiana, South of the Arkansas River, and between the Mississippi and River Grande. In American State Papers, Class II, Indian Affairs, Vol. 1, pp. 721-725. Gales \& Seaton, Washington, D.C.

1879 Vocabulary of the Caddo Language. American Naturalist 13(12):787-790.

Spier, L.

1924 Wichita and Caddo Relationship Terms. American Anthropologist 26:258263.

Story, D. A. 
1978 Some Comments on Anthropological Studies Concerning the Caddo. In Texas Archeology: Essays Honoring R. King Harris, edited by K. D. House, pp. 46-68. Southern Methodist University Press, Dallas.

Swanton, J. R.

1911 Indian Tribes of the Lower Mississippi Valley and Adjacent Coast of the Gulf of Mexico. Bulletin 43. Bureau of American Ethnology, Smithsonian Institution, Washington, D.C.

1931 The Caddo Social Organization and its Possible Historical Significance. Journal of the Washington Academy of Science 21(9).

1942 Source Material on the History and Ethnology of the Caddo Indians. Bulletin 132. Bureau of American Ethnology, Smithsonian Institution, Washington, D.C.

1946 The Indians of the Southeastern United States. Bulletin 137. Bureau of American Ethnology, Smithsonian Institution, Washington, D.C.

1952 The Indian Tribes of North America. Bulletin 145. Bureau of American Ethnology, Smithsonian Institution, Washington, D.C.

Tate, M. L.

1986 The Indians of Texas: An Annotated Research Bibliography. Native American Bibliography Series 9. Scarecrow Press, Metuchen, New Jersey.

Taylor, A. R.

1963 The Classification of the Caddoan Languages. Proceedings of the American Philosophical Society 107(1):51-59.

1963 Comparative Caddoan. International Journal of American Linguistics 29:113-151.

Teran, M. M.

1870 Noticia de las tribus de salvajes conocidos que habitats el Departamento de Tejas, y del numero de familias de que consta cada tribu, puntos en que habitats y terrenos en que acampan. Sociedad de Geografia y Estadistica de la Republica Mexicana Boletin 2:264-269.

Thornton, R.

1986 We Shall Live Again: The 1870 and 1890 Ghost Dance Movements as Demographic Revitalization. Cambridge University Press, New York.

1987 American Indian Holocaust and Survival A Population History Since 1492. University of Oklahoma Press, Norman. 
Thurman, M. D.

1973 Supplementary Material on the Life of John Wilson, 'The Revealer of Peyote.' Ethnohistory 20:279-287.

Troike, R. C.

1964 The Caddo Word for 'Water'. International Journal of American Linguistics 30:96-98.

Turner, M. W.

2009 Remarkable Plants of Texas: UnCommon Accounts of our Common Natives. University of Texas Press, Austin.

Vogel, R. C.

1995 The Yatasi of Northwest Louisiana: An Ethnohistorical Perspective. North Louisiana Historical Association Journal 26:10-33.

Wade, M. F.

1998 Por Las Espaldas se nos van Entrando con Silencio: Fr. Hidalgo's Letter to the Viceroy. Journal of Northeast Texas Archaeology 11:117-132.

2003 The Native Americans of the Texas Edwards Plateau, 1582-1799. University of Texas Press, Austin.

2005 Casanas, Hidalgo, and Espinosa: A Spanish Learning Curve. Caddoan Archeology Journal 14:75-77.

2008 Ethnohistoric and Ethnographic Assessment of Contemporary Communities along El Camino Real de Los Tejas National Historic Park. National Park Service, Santa Fe.

2008 Missions, Missionaries, and Native Americans: Long-Term Processes and Daily Practices. University Press of Florida, Gainesville.

Wallace, A. B.

2013 Native American Tattooing in the Protohistoric Southeast. In Drawing with Great Needles: Ancient Tattoo Traditions of North America, edited by A. Deter-Wolf and C. Diaz-Granados, pp. 1-41. University of Texas Press, Austin.

Wiegers, R. P.

1988 A Proposal for Indian Slave Trading in the Mississippi Valley and its Impact on the Osage. Plains Anthropologist 33(120):187-202.

Wood, W. R. 
2013 Ethnohistory and Euro-American Contact in Missouri. The Missouri Archaeologist 74:7-35.

Wright, M. H.

1951 A Guide to the Indian Tribes of Oklahoma. University of Oklahoma Press, Norman.

Zavala, A. de

1916 Religious Beliefs of the Tejas or Hasinai Indians. Publications of the Texas Folklore Society 1:39-43. 


\section{CADDO HISTORY}

Allen, C., S. Thomas, J. Grafton, B. Welton, L. Williams, K. McClure, D. Monteau, P. Cross, A. Hamblin, and W. Meyer

2006 Proposed Evaluation of Switchgrass Selections for Caddo House Construction. In Prairie Invaders: Proceedings of the $20^{\text {th }}$ North American Prairie Conference, University of Nebraska at Kearney, July 23-26, 2006, edited by J. T. Stringer and E. C. Springer, pp. 159-164. University of Nebraska at Kearney. http://digitalcommons.unl.edu/usarmyresearch/102.

Almonte, J. D.

1925 Statistical Report on Texas. Edited by C. E. Castaneda. Southwestern Historical Quarterly 28:177-222.

Anderson, G. C.

1999 The Indian Southwest, 1580-1830: Ethnogenesis and Reinvention. University of Oklahoma Press, Norman.

2005 The Conquest of Texas: Ethnic Cleansing in the Promised Land, 18201875. University of Oklahoma Press, Norman.

2014 Ethnic Cleansing and the Indian: The Crime that Should Haunt America. University of Oklahoma Press, Norman.

Attocknie, D.

2015 Caddo Food Traditions Go Beyond Corn, Beans and Squash. Native Oklahoma, May 2015, pp. 11-12.

Avery, G.

1996 Archival Investigations of the People of Los Adaes. Southern Studies VII(1): 65-88.

1997 More Friend Than Foe: Eighteenth Century Spanish, French, and Caddoan Interaction at Los Adaes; A Capital of Texas Located in Northwestern Louisiana. Louisiana Archaeology 22:163-193.

Babcock, M. M.

2014 Native Americans. In Discovering Texas History, edited by B. A. Glasrud, L. T. Cummins, and C. D. Wintz, pp. 15-30. University of Oklahoma Press, Norman.

Bagur, J. D.

1992 The Caddo Indian Village. Caddoan Archeology Newsletter 3(3):15-16.

2001 A History of Navigation on Cypress Bayou and the Lakes. University of North Texas Press, Denton. 
Bannon, J. F.

1970 The Spanish Borderlands Frontier, 1513-1821. Holt, Reinhart and Winston, New York.

Barr, J.

2015 Borders and Borderlands. In Why You Can't Teach United States History without American Indians, edited by S. Sleeper-Smith, J. Barr, J. M.

O'Broen, N. Shoemaker, and S. M. Stevens, pp. 9-25. University of North Carolina Press, Chapel Hill.

Barthm F. E.

1914 The Teran Expedition into Texas and Louisiana: Translation of the original documents with Introduction and Notes. Master of Letters, University of California, Berkeley.

Bedoka, G.

1999 Kee whut nah sundah people: a Caddo journey. The Kadohadacho Historical Society, Fort Cobb, Oklahoma.

Beers, H. P.

1957 The French in North America: A Bibliographic Guide to French Archives, Reproductions, and Research Missions. Louisiana State University Press, Baton Rouge.

Benavides, A., Jr.

1998 Archival Investigations for Mission Nuestra Senora de los Ais, San Augustine County, Texas: A Catalog of Documents and Maps of the Mission Dolores de los Ais Historical Materials Collection. Environmental Affairs Divisioon, Archeological Studies Program, Report No. 11. Texas Department of Transportation, Austin.

Berlandier, J. L.

1980 Journey to Mexico, During the Years 1826 to 1834 . Edited by S. M. Ohlendorf, J. M. Bigelow, and M. M. Standifer. 2 Vols. Texas State Historical Association, Austin.

Berry, J. M.

1917 The Indian Policy of Spain in the Southwest,1783-1795. Mississippi Valley Historical Review 3:462-477.

Berthelot, R. O., Jr.

1996 The Presidio Nuestra Senora del Pilar de los Adaes. Southern Studies VII(1): 25-44.

Best, J. R. 
1999 The Caddo Trace from Menard to Cleveland County, Arkansas. Field Notes (Newsletter of the Arkansas Archeological Society Survey) 290:3-4.

Bolton, H. E.

1908 The Native Tribes about the East Texas Missions. Texas State Historical Association Quarterly 11:249-276.

1912 The Spanish Occupation of Texas, 1519-1690. Southwestern Historical Quarterly 16:1-26.

1915 Texas in the Middle Eighteenth Century: Studies in Spanish Colonial History and Administration. University of California Press, Berkeley.

1916 Spanish Exploration in the Southwest, 1542-1706. Charles Scribner's Sons, New York.

1917 The Mission as a Frontier Institution in the Spanish-American Colonies. American Historical Review 23:42-61.

1920 The Spanish Borderlands. A Chronicle of Old Florida and the Southwest. Yale University Press, New Haven.

Bolton, H. E. (editor)

1914 Athanase de Mezieres and the Louisiana-Texas Frontier, 1768-1780. 2 Vols. Clark Publishing, Cleveland.

Bourne, E. G. (translator)

1904 Narratives of the Career of Hernando de Soto. Merton, New York.

Bridges, K. and W. DeVille (editors and translators)

1967 Natchitoches and the Trail to the Rio Grande: Two Early Eighteenth Century Accounts by the Sieur Derbanne. Louisiana History 8(3):239-259.

Britton, M. L.

1996 Le Poste des Cadodaquious. In The New Handbook of Texas, Vol. 4, edited by R. Tyler, pp. 167-168. Texas State Historical Association, Austin.

Bruseth, J. E.

1996 Moscoso Expedition. In The New Handbook of Texas, Vol. 4, edited by R. Tyler, pp. 851-852. Texas State Historical Association, Austin.

Bruseth, J. E. and N. A. Kenmotsu

1991 Soldiers of Misfortune: The de Soto Expedition Through Texas. Heritage 9:12-18. Texas Historical Foundation, Austin. 
1993 From Naguatex to the River Daycao: The Route of the Hernando de Soto Expedition Through Texas. North American Archaeologist 14(2):99-125.

Buckley, E. C.

1911 The Aguayo Expedition into Texas and Louisiana, 1719-1722. Texas State Historical Association Quarterly 15:1-65.

Burton, H. S. and F. T. Smith

2008 Colonial Natchitoches: A Creole Community on the Louisiana-Texas Frontier. Texas A\&M University Press, College Station.

Caddo Nation of Oklahoma

2003 Cane River Oral History Handbook. cane River National Heritage Area Commission, Natchitoches.

Calloway, C. G.

2003 One Vast Winter Count: The Native American West before Lewis and Clark. University of Nebraska Press, Lincoln.

Canedo, L. G. (editor)

1968 Primeras Exploraciones y Poblamiento de Texas (1686-1694). Serie Historia 6. Publicaciones del Instituto de Estudios Superiores de Monterrey, Mexico.

Carlson, S. B.

1996 Where in the World (System) are the Texas Missions? Southern Studies VII(1):1-24.

Carter, C. E.

1995 Caddo Indians: Where We Come From. University of Oklahoma Press, Norman.

1995 Caddo Turkey Dance. In Remaining Ourselves: Music and Tribal Memory: Traditional Music in Contemporary Communities, edited by D. B. Lee, pp. 31-36. State Arts Council of Oklahoma, Oklahoma City.

Carter, C. E. (editor)

1933 The Territorial Papers of the United States. 28 Vols. Government Printing Office, Washington, D.C.

Castaneda, C. E.

1936 Our Catholic Heritage in Texas. 6 Vols. V. Von Boeckmann-Jones Co., Austin.

Celiz, F. de 
1935 Diary of the Alarcon Expedition into Texas, 1718-1719, by Francisco de Celiz. Translated and edited by F. L. Hoffmann. Quivira Society, Los Angeles.

Chapa, J. B.

1997 Texas \& Northeastern Mexico, 1630-1690. Edited and with an Introduction by W. C. Foster. University of Texas Press, Austin.

Chapman, B. B.

1955 Establishment of the Wichita Reservation. Chronicles of Oklahoma 33:1044-1055.

Chipman, D. E.

1992 Spanish Texas, 1519-1821. University of Texas Press, Austin.

1995 Alonso de Leon: Pathfinder in East Texas, 1686-1690. East Texas Historical Journal 33:3-17.

Chipman, D. E. and H. D. Joseph

2001 Notable Men and Women of Spanish Texas. University of Texas Press, Austin.

2010 Spanish Texas, 1519-1821. Revised Edition. University of Texas Press, Austin.

Chipman, D. E. and R. S. Weddle

2013 How Historical Myths are Born... and why they Seldom Die. Southwestern Historical Quarterly 116(3):227-258.

Clark, B.

2009 Indian Tribes of Oklahoma: A Guide. University of Oklahoma Press, Norman.

Clark, R. C.

1902 Louis Juchereau de Saint-Denis and the Re-Establishment of the Tejas Missions. Texas State Historical Association Quarterly 6:1-26.

1907 The Beginnings of Texas, 1684-1718. Publication 98. University of Texas at Austin.

Clayton, L. A., V. J. Knight, Jr., and E. C. Moore (editors)

1993 The De Soto Chronicles: The Expedition of Hernando de Soto to North America in 1539-1543. 2 Vols. University of Alabama Press, Tuscaloosa.

Cochran, K. B. 
1995 The Native Americans (Kadohadacho) of Caddo Lake. K. B. Cochran, Shreveport, Louisiana.

Cook, D. G.

2008 Battle Creek: Where Surveyors Fought Like Soldiers. Wild West 21(4):5459.

Corbin, J. E.

1991 Retracing the Camino de los Tejas from the Trinity to Los Adaes: New Insights into East Texas History. In A Texas Legacy: The Old San Antonio Road and the Caminos Reales. A Tricentennial History; 1691-1991, edited by A. J. McGraw and J. W Clark, pp. 191-219. Highway Design Division, Texas State Department of Highways and Public Transportation, Austin.

Cox, I. J.

1904 The Explorations of the Louisiana Frontier, 1803-1806. American Historical Association Annual Report, pp. 151-174 and pp. 274-284.

1906 The Early Exploration of Louisiana. University Studies, Series 2, Vol. 11, No. 1. University of Cincinnati, Cincinnati.

1909 The Significance of the Texas-Louisiana Frontier. Mississippi Valley Historical Association Proceedings 3:198-213.

1922 The Journeys of Rene Robert Cavelier, Sieur de La Salle. 2 Vols. Allerton Book Co., New York.

Cross, P. and M. Meeks

2011 Caddo Culture Club Activities. Caddo Archeology Journal 21:181-183.

Crouch, C. J.

1996 Brazos Indian Reservation. In The New Handbook of Texas, Vol. 1, edited by R. Tyler, pp. 714-715. Texas State Historical Association, Austin.

Cunningham, D. S.

2004 Domingo Ramon's 1716 Expedition into Texas: On Foik's Translation. Southwest Journal of Linguistics 23:35-43.

2006 The Domingo Ramon Diary of the 1716 Expedition into the Province of the Tejas Indians: An Annotated Translation. Southwestern Historical Quarterly 110:38-67.

Curtz, K.

1981 The Routes of French and Spanish Penetration into Oklahoma. Red River Valley Historical Review 6:18-30. 
Delangez, J.

1938 The Journal of Jean Cavelier: The Account of a Survivor of La Salle's

Texas Expedition, 1684-1688. Institute of Jesuit History, Chicago.

1944 The Voyages of Tonti in North America. Mid-America 26:255-297.

Dunbar, J. B.

1880 The Pawnee Indians: Their History and Ethnology. Magazine of American History with Notes and Queries 4:241-281.

Dunn, W. C.

1917 Spanish and French Rivalry in the Gulf Region of the United States, 16781702: The Beginnings of Texas and Pensacola. Books for Libraries Press, Freeport, New York.

Du Pratz, A.

1758 Historie de la Louisiane Francaise. 4 Vols. de Bere, Paris.

DuVal, K.

2006 The Native Ground: Indians and Colonists in the Heart of the Continent. University of Pennsylvania Press, Philadelphia.

Eakin, W. L.

1997 The Kingdom of the Tejas: The Hasinai Indians at the Crossroads of Change. Ph.D. Dissertation, Department of History, University of Kansas, Lawrence.

Earles, C. K.

2012 Caddo Pottery in Modern and Contemporary Art, and Protection of Native American Cultures in Fine Arts by the IACB's Indian Arts and Crafts Act. Caddo Archeology Journal 22:9-16.

Edmonds, $\mathrm{R}$.

1995 Ghost Dance Somgs. In Remaining Ourselves: Music and Tribal Memory: Traditional Music in Contemporary Communities, edited by D. B. Lee, p. 54. State Arts Council of Oklahoma, Oklahoma City.

2003 Nusht' uhti?ti? Hasinay: Caddo Language Phrase Book. Various Indian Peoples Publishing, Richardson, Texas.

Estep, R. (editor)

1961 The Removal of the Texas Indians and the Founding of Fort Cobb: Lieutenant William E. Burnet Letters. Oklahoma Historical Society, Oklahoma City.

Ethridge, R. 
2010 From Chicaza to Chickasaw: The European Invasion and the Transformation of the Mississippian World, 1540-1715. University of North Carolina Press, Chapel Hill.

2012 The Emergence of the Colonial South: Colonial Indian Slaving, the Fall of the Precontact Mississippian World, and the Emergence of a New Social Gepgraphy in the American South, 1540-1730. In Native American Adoption, Captivity, and Slavery in Changing Contexts, edited by M. Carocci and S. Pratt, pp. 47-63. Palgrave MacMillan, New York.

2013 Contact Era Studies and the Southeastern Indians. In Native and Spanish New Worlds: Sixteenth-Century Entradas in the American Southwest and Southeast, edited by C. Mathers, J. M. Mitchem, and C. M. Haecker, pp. 63-77. University of Arizona Press, Tucson.

Ethridge, R. and J. M. Mitchem

2013 The Interior South at the Time of Spanish Exploration. In Native and Spanish New Worlds: Sixteenth-Century Entradas in the American Southwest and Southeast, edited by C. Mathers, J. M. Mitchem, and C. M. Haecker, pp. 170-188. University of Arizona Press, Tucson.

Everett, D.

1990 The Texas Cherokee: A People Between Two Fires, 1811-1840. University of Oklahoma Press, Norman.

Fair, R. S.

2007 Social Networks and Knowledge Systems among the Caddo and Delaware of Western Oklahoma. Ph.D. dissertation, Department of Anthropology, University of Oklahoma, Norman.

Fernandez-Armesto, $\mathrm{F}$.

2014 Our America: A Hispanic History of the United States. W. W. Norton \& Company, New York.

Flores, D. L. (editor)

1984 Jefferson and Southwestern Exploration: The Freeman and Custis Accounts of the Red River Expedition of 1806. University of Oklahoma Press, Norman.

1985 Journal of an Indian Trader: Anthony Glass and the Texas Trading Frontier, 1790-1810. Texas A\&M University Press, College Station.

2002 Southern Counterpart to Lewis \& Clark, The Freeman \& Custis Expedition of 1806. Red River Books, University of Oklahoma Press, Norman. 
2015 A Very Different Story: Exploring the Southwest from Monticello. Oklahoma Humanities 8(2):7-11.

Foik, P. J. (translator)

1933 Captain Don Domingo Ramon's Diary of His Expedition into Texas in 1716. Preliminary Studies of the Texas Catholic Historical Society 11(5):128.

Ford, J. S.

1963 Rip Ford's Texas. Edited by S. B. Oates. University of Texas Press, Austin.

Forrestal, P. P.

1931 The Solis Diary of 1767. Preliminary Studies of the Texas Catholic Historical Society 1(6):18-66.

1935 Pena's Diary of the Aguayo Expedition. Preliminary Studies of the Texas Catholic Historical Society 11(7):2-68.

Foster, W. C.

1995 Spanish Expeditions into Texas, 1689-1768. University of Texas Press, Austin.

2008 Historic Native Peoples of Texas. University of Texas Press, Austin.

Foster, W. C. (editor)

1998 The La Salle Expedition to Texas: The Journal of Henri Joutel, 1684-1687. Texas State Historical Association, Austin.

2003 The La Salle Expedition on the Mississippi River: A Lost Manuscript of Nicolas de La Salle. Texas State Historical Association, Austin.

Foster, W. C. and J. Jackson (editors) with N. F. Brierley (translator) 1993 The 1693 Expedition of Governor Salinas Varona to Sustain the Missionaries among the Tejas Indians. Southwestern Historical Quarterly 97:264-311.

Freeman, T. and P. Custis

1984 An Account of the Red River in Louisiana Drawn up from the Returns of Messrs Freeman and Custis in the War Office of the United States, who Explored the Same in the Year 1806. Ye Galleon Press, Fairfield.

Galan, F. X.

2006 Last Soldiers, First Pioneers: The Los Adaes Border Community on the Louisiana-Texas Frontier, 1721-1779. Ph.D. dissertation, Southern Methodist University, Dallas. 
2008 Presidio Los Adaes: Worship, Kinship, Commerce with French Natchitoches on the Spanish-Franco-Caddo Borderlands, 1721-1773. Louisiana History 49:191-208.

2010 Lost in Translation: Tejano Roots on the Louisiana-Texas Borderlands, 1716-1821. In Recovering the Hispanic History of Texas, edited by M. Perales and R. A. Ramos, pp. 3-18. Arte Publico Press, Houston.

Garrett, J. K.

1942-1946 Letters and Documents: Dr. John Sibley and the Louisiana-Texas Frontier, 1803-1814. Southwestern Historical Quarterly 45-49.

Gerhard, P.

1993 The North Frontier of New Spain. University of Oklahoma Press, Norman.

Gilmore, K.

1992 French, Spanish, and Indian Interaction in Colonial Texas. Bulletin of the Texas Archeological Society 63:123-133.

Giraud, M.

1953-1974 Histoire de la Louisiana Francaise. 4 Vols. Presses Universitaires de France, Paris.

Glover, W. R.

1935 A History of the Caddo Indians. Louisiana Historical Quarterly 18(4):872946.

Goldberg, M. A.

2009 Negotiating Nacogdoches: Hasinai Caddo-Spanish Relations, Trade Space, and the Formation of the Texas-Louisiana Border, 1779-1819. American Indian Culture and Research Journal 33.

Gregory, H.F., G. Avery, A. L. Lee, and J. C. Blaine 2004 Presidio Los Adaes: Spanish, French, and Caddoan Interaction on the Northern Frontier. Historical Archaeology 38(3):65-77.

Hackett, C. W.

1945 The Marquis of San Miguel de Aguayo and his Recovery of Texas from the French, 1719-1723. Southwestern Historical Quarterly 49:193-214.

Hackett, C. W. (editor and translator)

1931-1946 Pichardo's Treatise on the Limits of Louisiana and Texas. 4 Vols. University of Texas Press, Austin.

Hadley, D., T. H. Naylor, and M. K. Schuetz-Miller (compilers and editors) 
1997 The Presidio and Militia on the Northern Frontier of New Spain: A Documentary History. Volume Two, Part Two: The Central Corridor and the Texas Corridor, 1700-1765. University of Arizona Press, Tucson.

Haggard, J. V.

1940 Spain's Indian Policy in Texas. Southwestern Historical Quarterly 43:479485.

1945 The Neutral Ground between Louisiana and Texas, 1806-1821. Louisiana Historical Quarterly 28:1001-1128.

Hamalainen, $P$.

2011 Into the Mainstream: The Emergence of a New Texas Indian History. In Beyond Texas Through Time: Breaking Away from Past Interpretations, edited by W. L. Buenger and A. De Leon, pp. 50-84. Texas A\&M University Press, College Station.

2014 The Shapes of Power: Indians, Europeans, and North American Worlds from the Seventeenth to the Nineteenth Century. In Contested Spaces of Early America, edited by J. Barr and E. Countryman, pp. 31-68. University of Pennsylvania Press, Philadelphia.

Harmon, G. D.

1930 The United States Indian Policy in Texas, 1845-1860. The Mississippi Valley Historical Review 17:377-403.

Harrison, J. T.

2012 Franciscan Missionary Theory and Practice in Eighteenth-Century New Spain: The Propaganda Fide Friars in the Texas Missions, 1690-1821. Ph.D. dissertation.

Hatcher, M. A.

1919 Texas in 1820: Report on the Barbarous Indians of the Province of Texas. Southwestern Historical Quarterly 23:147-168.

1927 The Louisiana Background of the Colonization of Texas, 1763-1803. Southwestern Historical Quarterly 30:169-194.

1932 The Expedition of Don Domingo Teran de los Rios into Texas. Preliminary Studies of the Texas Catholic Historical Society II(1):3-62.

Horse Capture, G. P., Sr.

2011 The Plains. In Indian Nations of North America, by A. Treuer, K. Wood, W. W. Fitzhugh, G. P. Horse Capture, Sr., T. L. Fraizer, M. R. Miller, M. Belarde-:ewis, and J. Norwood, pp. 144-193. National Geographic, Washington, D.C. 
Hosmer, B. C.

1996 Jose Maria. In The New Handbook of Texas, Vol. 3, edited by R. Tyler, p. 1004. Texas State Historical Association, Austin.

Hudson, C.

1985 De Soto in Arkansas: A Brief Synopsis. Field Notes (Arkansas Archeological Society) 205:3-12.

Hyde, A. F.

2012 Empires, Nations, and Families: A New History of the North American West, 1800-1860. Ecco, HarperCollins Publishers, New York.

Ibarra, C. G.

1987 Como Mexico perdio Texas: Analisis y transcripcion del informe secreto 1834 de Juan Nepomuceno Almonte. Instituto Nacional de Antropologica a Historia, Mexico City.

Jackson, J.

1995 Flags along the Coast: Charting the Gulf of Mexico, 1519-1759: A Reappraisal. The Book Club of Texas, Lubbock.

1999 Shooting the Sun: Cartographic Results of Military Activities in Texas, 1689-1829. The Book Club of Texas, Lubbock.

2005 Indian Agent: Peter Ellis Bean in Mexican Texas. Texas A\&M University Press, College Station.

Jackson, J. (editor)

1995 Imaginary Kingdom: Texas as Seen by the Rivera and Rubi Military Expeditions, 1727 and 1768. Texas State Historical Association, Austin.

2000 Texas by Teran: The Diary Kept by General Manuel de Mier y Teran on his 1828 Inspection of Texas. University of Texas Press, Austin.

2003 Almonte's Texas: Juan N. Almonte's 1834 Inspection, Secret Report \& Role in the 1836 Campaign. Texas State Historical Association, Austin.

Jackson, J., R. S. Weddle, and W. DeVille

1990 Mapping Texas and the Gulf Coast. The Contributions of Saint Denis, Olivan, and Le Maire. Texas A\&M University Press, College Station.

Jackson, R. H.

2004 Congregation and Depopulation: Demographic Patterns in Texas Missions. Journal of South Texas 17(2):6-38. 
2005 Missions and the Frontiers of Spanish America: A Comparative Study of the Impact of Environmental, Economic, Political, and Socio-Cultural Variations on the Missions in the Rio de la Plata Region and on the Northern Frontier of New Spain. Pentacle Press, Scottsdale, Arizona.

Jelks, E. B.

1970 Documentary Evidence of Indian Occupation at the Stansbury Site (4139B1-1). Bulletin of the Texas Archeological Society 41:277-286.

1996 Towash. In The New Handbook of Texas, Vol. 6, edited by R. Tyler, p. 537. Texas State Historical Association, Austin.

John, E. A. H.

1975 Storms Brewed in Other Men's Worlds: The Confrontation of Indians, Spanish, and French in the Southwest, 1540-1795. Texas A\&M University Press, College Station.

1985 La Situacion y Vision de los Indios de la Frontera Norte de Nueva Espana (siglos XVI-XVIII). America Indigena 45(3):465-483.

John, E. A. H. (editor) and J. Wheat (translator)

1989 Views from the Apache Frontier: Report on the Northern Provinces of New Spain by Jose Cortes, Lieutenant in the Royal Corps of Engineers, 1799. University of Oklahoma Press, Norman.

Jones, C. A.

2005 Texas Roots: Agriculture and Rural Life before the Civil War. Texas A\&M University Press, College Station.

Joutel, $\mathrm{H}$.

1906 [1713] A Historical Journal of the Late Monsieur de LaSalle's Last Voyage into North America to Discover the River Mississippi. Edited by H. R Stiles. Joseph McDonough, New York.

Kinnaird, L. (editor)

1949 Spain in the Mississippi Valley, 1765-1794. 3 Vols. Annual Report for the Year 1945. American Historical Association, Washington, D.C.

1958 The Frontiers of New Spain: Nicolas de Lafora's Description, 1766-1768. Quivira Society, Berkeley.

Klos, G.

1994 "Our People Could Not Distinguish One Tribe from Another": The 1859 Expulsion of the Reserve Indians from Texas. Southwestern Historical Quarterly 97(4):599-619. 
1996 Indians. In The New Handbook of Texas, Vol. 3, edited by R. Tyler, pp. 838-849. Texas State Historical Association, Austin.

Koch, L. C.

1925 The Federal Indian Policy in Texas, 1845-1860. Southwestern Historical Quarterly 28(3)-29(2).

Kress, M. K. and M. A. Hatcher

1932 Diary of a Visit of Inspection of the Texas Missions Made by Fray Gaspar Jose de Solis in the Year 1767-1768. Southwestern Historical Quarterly 35:28-76.

Lange, C.

1974 A Report on Data Pertaining to the Caddo Treaty of July 1, 1835: The Historical and Anthropological Background and Aftermath. In Caddoan Indians, Volume II, pp. 59-320. Garland Publishing, New York.

La Vere, D.

2004 The Texas Indians. Texas A\&M University Press, College Station.

La Vere, D. and K. Campbell (editor and translator)

1994 An Expedition to the Kichai: The Journal of Francois Grappe, September 24, 1783. Southwestern Historical Quarterly 98(1):58-78.

Lee, A. L.

1990 Fusils, Paint, and Pelts: An Examination of Natchitoches-Based Indian Trade in the Spanish Period, 1766-1791. Master's thesis, Northwestern State University, Natchitoches.

Lee, D. B.

2010 "Caddo Nation." KnowLA Encyclopedia of Louisiana. http://www.www.knowla.org/entry.php?rec=607 (accessed May 3, 2011).

2012 From Captives to Kin: Indian Slavery and Changing Social Identities on the Louisiana Colonial Frontier. In Native American Adoption, Captivity, and Slavery in Changing Contexts, edited by M. Carocci and S. Pratt, pp. 79-96. Palgrave MacMillan, New York.

Lemee, P. R.

1998 Tios and Tantes: Familial and Political Relationships of Natchitoches and the Spanish Colonial Frontier. Southwestern Historical Quarterly 101(3):340-358.

2014 St. Denis, The Caddo, and Others: Letters from Patty Lemee. Caddo Archeology Journal 24:139-160. 
Lewis, A.

1924 La Harpe's First Expedition in Oklahoma, 1718-1719. Chronicles of Oklahoma 2:331-249.

Lookingbill, B. D.

2006 War Dance at Fort Marion: Plains Indian War Prisoners. University of Oklahoma Press, Norman.

Loren, D. D.

1996 Colonial Dress at the Spanish Presidio of Los Adaes. Southern Studies VII(1):45-64.

1999 Creating Social Distinction: Articulating Colonial Policies and Practices along the Eighteenth-Century Louisiana/Texas Frontier. Ph.D. dissertation, Department of Anthropology, State University of New York at Binghamton.

2000 The Intersections of Colonial Policy and Colonial Practice: Creolization on the Eighteenth-Century Louisiana/Texas Frontier. Historical Archaeology 34(3):85-98.

2001 Manipulating Bodies and Emerging Traditions at the Los Adaes Presidio. In The Archaeology of Traditions: Agency and History Before and After Columbus, edited by T. R. Pauketat, pp. 58-76. University of Florida Press, Gainsville.

2007 Corporeal Concerns: Eighteenth-Century Casta Paintings and Colonial Bodies in Spanish Texas. Historical Archaeology 41(1):23-36.

Lyon, $\mathrm{O}$.

1952 The Trail of the Caddo. Arkansas Historical Quarterly 11:124-130.

Magnaghi, R. M.

1976 The Red River Valley North of Natchitoches, 1817-1818. Louisiana Studies 15(3):287-293.

1978 Sulphur Fork Factory, 1817-1822. Arkansas Historical Quarterly 27(2):168-183.

Margry, $\mathrm{P}$.

1876-1884 Decouvertes et Etablissements des Francais dans l'Ouest et dans le Sud de l'Amerique Septentrionales (1614-1754). 6 Vols. D. Jouaust, Paris.

McCollough, M. 
1996 Three Analytical Approaches to Comanche and Caddoan Histories during Spain's Colonial Occupation of the Southern Plains, 1689-1821. Ph.D. dissertation, Department of History, University of Oklahoma, Norman.

2004 Three Nations, One Place: A Comparative Ethnohistory of Social Change Among the Comanches and Hasinais During Spain's Colonial Era. Routledge, New York and London.

McDonald, A. P.

1969 Hurrah for Texas! The Diary of Adolphus Sterne 1838-1851. Texian Press, Waco.

McDonald, D., K. Hindes, and K. Gilmore

1999 The Marqués De Aguayo's Report to the King Regarding His Expedition to Restore and Establish Missions and Presidios in Texas, 1720-1722. Bulletin of the Texas Archeological Society 70:59-64.

McGinty, G. W.

1963 Valuating the Caddo Land Cession. Louisiana Studies 2:59-73.

McWilliams, R. G.

1953 Fleur de Lys and Calumet: Being the Penicaut Narrative of French Adventure in Louisiana. Louisiana State University Press, Baton Rouge.

1981 Iberville's Gulf Journals. University of Alabama Press, Tuscaloosa.

Meeks, M.

20122011 Caddo Culture Club Activities. Caddo Archeology Journal 22:153157.

20132012 Caddo Culture Club Activities Report. Caddo Archeology Journal 23:165-168.

20142013 Caddo Culture Club Activities Report. Caddo Archeology Journal 24:187-190.

20152014 Caddo Culture Club Activities Report. Caddo Archeology Journal 25:181-183.

20162015 Caddo Culture Club Activities Report. Caddo Archeology Journal 26: 87-88.

2017 Report on the 2016 Caddo Culture Club Activities. Caddo Archeology Journal 27:114-115.

Meredith, H. L. 
1995 Dancing on Common Ground-Tribal Cultures and Alliances on the Southern Plains. University Press of Kansas, Lawrence.

2002 Cultural Conservation and Revival: The Caddo and Hasinai Post Removal Era, 1860-1902. The Chronicles of Oklahoma 72(3):278-287.

Mitchell, $P$.

2015 Horse Nations: The Worldwide Impact of the Horse on Indigenous Societies Post-1492. Oxford University Press, Oxford.

Morfi, J.

1932 Excerpts from the Memorias for the History of the Province of Texas. Edited and translated by F. C. Chabot. Naylor Printing Company, San Antonio.

1935 History of Texas, 1663-1779. Quivira Society Publications No. 6. Edited by C. E. Castaneda. Quivira Society, Santa Fe.

Murphy, R.

1937 The Journey of Pedro de Rivera, 1724-1728. Southwestern Historical Quarterly 41:125-141.

Nasatir, A. P. (editor)

1952 Before Lewis and Clark: Documents Illustrating the History of the Missouri, 1785-1804. 2 Vols. St. Louis Documents Foundation, St. Louis.

Nasatir, A. P., and N. M. Loomis

1967 Pedro Vial and the Roads to Santa Fe. University of Oklahoma Press, Norman.

Neighbours, K. E.

1957 Chapters from the History of the Texas Indian Reservation. West Texas Historical Association Year Book 33:3-16.

1960 Indian Exodus out of Texas in 1859. West Texas Historical Association Year Book 36:80-97.

1966 Jose Maria, Anadarko Chief. Chronicles of Oklahoma 30:254-274.

1973 Indian Exodus: Texas Indian Affairs, 1835-1859. Nortex Offser Publications, Quannah.

1975 Robert Simpson Neighbors and the Texas Frontier, 1836-1859. Texian Press, Waco.

Neuman, R. W. 
1974 Historic Locations of Certain Caddoan Tribes. In Caddoan Indians, Volume II, pp. 9-147. Garland Publishing, Inc., New York.

Norris, L. A.

2017 General Alonso de Leon's Expeditions into Texas, 1686-1690. Texas A\&M University Press, College Station.

Nuttall, T. (edited by S. Lottinville)

1980 A Journal of Travels into the Arkansas Territory During the Year 1819. University of Oklahoma Press, Norman.

Perez, A. I.

2013 Tejano Rangers: The Development and Evolution of Ranging Tradition, 1540-1880. Ph.D. dissertation, Department of History, University of lowa, Ames.

Perttula, T. K. (moderator)

1996 "Two Worlds Meet: The Caddoan People and Missions." Journal of Northeast Texas Archaeology 7:69-91.

1997 Two Worlds Meet: The Caddoan People and Missions. El Campanario 28(2):9-12.

Pinkerton, G. L.

2016 Trammel's Trace: The First Road to Texas from the North. Texas A\&M University Press, College Station.

Pleasant, D.

2013 Documentary Evidence for the Eighteenth and Nineteenth Century Location of the Adaes Indians. Caddo Archeology Journal 23:115-140.

2014 The Ranchos of Los Adaes: Spanish Geography and American Land Claims in Western Louisiana. Caddo Archeology Journal 24:117-138.

Porter, C.

2008 Queretaro in Focus: The Franciscan Missionary Colleges and the Texas Missions. Catholic Southwest 19:9-51.

Purser, J.

1964 The Administration of Indian Affairs in Louisiana, 1803-1820. Louisiana History 5:401-419.

Ritchie, E. B. (editor)

1939 Copy of Report of Colonel Samuel Cooper, Assistant Adjutant General of the United States, of Inspection Trip from Fort Graham to the Indian 
Villages on the Upper Brazos made in June, 1851. Southwestern Historical Quarterly 42:327-333.

Robertson, J. A. (translator and editor)

1933 True Relation of the Hardships Suffered by Governor Fernando de Soto and Certain Portuguese Gentlemen during the Discovery of the Province of Florida now Newly Set Forth by a Gentleman of Elvas. Publications No. 11. Florida Historical Society, De Land.

Ruffin, T. F.

1971 Invasion of Caddo Parish by General Thomas Jefferson Rusk's Republic of Texas Army, 1838. North Louisiana Historical Association Journal 2:7183.

Salcedo, M. M. de

1968 A Governor's Report on Texas in 1809. Edited by N. L. Benson. Southwestern Historical Quarterly 71:603-616.

Sanchez, J. M.

1926 A Trip to Texas in 1828. Translated by C. E. Castaneda. Southwestern Historical Quarterly 29:249-288.

Santos, R. G. (compiler and translator)

1981 Aquayo Expedition into Texas, 1721: An Annotated Translation of the Five Versions of the Diary Kept by Br. Juan Antonio de la Pena. Jenkins Publishing, Austin.

Shelby, C. C.

1923 St. Denis's Declaration Concerning Texas in 1717. Southwestern Historical Quarterly 26(3):165-183.

1924 St. Denis's Second Expedition to the Rio Grande, 1716-1719. Southwestern Historical Quarterly 27:190-216.

1927 St. Denis's Second Expedition from Louisiana to the Rio Grande, 17161719. Master's thesis, Department of History, The University of Texas at Austin.

1933 International Rivalry in Northeastern New Spain, 1700-1725. Ph.D. dissertation, Department of History, The University of Texas at Austin.

Sibley, J.

1922 A Report from Natchitoches in 1807. Edited by A. H. Abel. Indian Notes and Monographs, Museum of the American Indian, Heye Foundation, New York. 
Smith, F. T.

1989 On the Convergence of Empire: The Caddo Indian Confederacies, 15421835. Ph.D. dissertation, Department of History, Tulane University, New Orleans.

1989 After the Treaty of 1835: The United States and the Kadohadacho Indians. Louisiana History 30:157-172.

1991 The Kadohadacho Indians and the Louisiana-Texas Frontier, 1803-1815. Southwestern Historical Quarterly 95(2):176-204.

1994 The Red River Caddos: A Historical Overview to 1835. Bulletin of the Texas Archeological Society 65:115-127.

1995 The Caddo Indians: Tribes at the Convergence of Empires, 1542-1854. Texas A\&M University Press, College Station.

1996 The Caddos, the Wichitas and the United States, 1846-1901. Texas A\&M University Press, College Station.

1996 Spanish Indian Policy in Louisiana: The Natchitoches District, 1763-1803. In The Spanish Presence in Louisiana, edited by G. C. Din, pp. 284-295. Center for Louisiana Studies, Lafayette.

1996 A Native Response to the Transfer of Louisiana: The Red River Caddos and Spain, 1762-1803. Louisiana History 37:163-185.

1998 The Political History of the Caddo Indians, 1686-1874. In The Native History of the Caddo: Their Place in Southeastern Archeology and Ethnohistory, edited by T. K. Perttula and J. E. Bruseth, pp. 175-181. Studies in Archeology No. 30. Texas Archeological Research Laboratory, University of Texas at Austin.

1998 The Kadohadacho Indians and the Louisiana-Texas Frontier, 1803-1815. In The Louisiana Purchase and its Aftermath, edited by D. E. Labbe, pp. 197-200. Center for Louisiana Studies, Lafayette.

2000 The Wichita Indians: Traders of Texas and the Southern Plains, 15401845. Texas A\&M University Press, College Station.

2003 Athanase de Mezieres and the French in Texas, 1750-1803. In the French in Texas: History Migration, Culture, edited by F. Lagarde, pp. 46-59. University of Texas Press, Austin.

2004 Caddo Indians. In The Encyclopedia of the Great Plains, edited by D. J. Wishart, pp. 568-569. University of Nebraska Press, Lincoln. 
2005 From Dominance to Disappearance: The Indians of Texas and the Near Southwest, 1786-1859. University of Nebraska Press, Lincoln.

2008 Dehahuit, Indian Diplomat on the Louisiana-Texas Frontier, 1804-1815. In Nexus of Empire: Loyalty and National Identity in the Gulf Borderlands, 1763-1821, edited by G. Smith. University of Alabama Press, Tuscaloosa.

2010 Texas through 1845: A Survey of the Historical Literature of Recent Decades. Southwestern Historical Quarterly 113(3):311-341.

2014 Louisiana and the Gulf South Frontier 1500-1821. Louisiana State University Press, Baton Rouge.

Smith, R. A.

1958-1959 Account of the Journey of Benard de la Harpe: Discovery Made by Him of Several Nations Situated in the West. Southwestern Historical Quarterly 62(1-4).

Smith, R. L.

2002 Jose Maria was the last Caddo chief on the often inhospitable Texas frontier. Wild West 15(3):20, 60-61.

Southwell, K. L. and J. R. Lovett

2010 Life at the Kiowa, Comanche, and Wichita Agency: The Photographs of Annette Ross Hume. University of Oklahoma Press, Norman.

Speck, F. G.

1933 Notes on the Life of John Wilson, the Revealer of Peyote, as Recalled by His Nephew George Anderson. The General Magazine and Historical Chronicle 53:539-556.

Stagg, J. C. A.

2009 Borderlines in Borderlands: James Madison and the Spanish-American Frontier, 1776-1821. Yale University Press, New Haven.

Steele, C. (translator)

1985 A Journey through Texas in 1767. El Campanario: Texas Old Missions and Forts Restoration Association 16(1):1-28.

Strickland, R. W.

1937 Anglo-American Activities in Northeastern Texas 1803-1845. Ph.D. dissertation, Department of History, The University of Texas at Austin.

1942 Moscoso's Journey through Texas. Southwestern Historical Quarterly 46:109-137. 
2011 Red River Pioneers: The Story of Anglo-American Activities in Northeast Texas, Southeast Oklahoma and Southwest Arkansas. MC\&S Enterprises/Wright Press, Sherman, Texas.

Surrey, N. M. M.

1916 The Commerce of Louisiana During the French Regime, 1699-1763. Studies in History, Economics, and Public Law, Vol. 71. Columbia University, New York.

Swanton, J. R.

1952 Hernando De Soto's Route Through Arkansas. American Antiquity 18(2):156-162.

1985 Final Report of the United States De Soto Expedition Commission. Classics in Anthropology Series. Smithsonian Institution Press, Washington, D.C.

Tanner, H. H.

1974 The Territory of the Caddo Tribe of Oklahoma. In Caddoan Indians, Vol. 4, pp. 9-144. Garland Publishing, Inc., New York.

1993 The Caddos in the Era of the Republic of Texas. 3 Parts. Caddo Nation News 2 (Nos. 2-4).

Tate, M. L.

1995 Indian-White Relations in Texas, 1821-1875. In The Indian Papers of Texas and the Southwest, 1825-1916, Vol. 1, edited by D. H. Winfrey and J. M. Day, pp. ix-xxi. Texas State Historical Association, Austin.

Tiller, J.

2007 The Shreveport Caddo, 1835-1838. Journal of Northeast Texas Archaeology 26:159-167.

2008 Was Timber Hill the Last Caddo Village in the Caddo Homeland? Caddo Archeology Journal 18:11-21.

2010 A Case for Dehahuit's Village, Part I. Caddo Archeology Journal 20:1-30.

2010 Before the Line. Vol. I, An Annotated Atlas of International Boundaries and Republic of Texas Administrative Units Along the Sabine River-Caddo Lake Borderland, 1803-1841. The START Group, Huntsville, Texas.

2011 A Case for Dehahuit's Village, Part II. Caddo Archeology Journal 21:107127. 
2012 Before the Line. Vol. II, Letters from the Red River, 1809-1842. The START Group, Huntsville, Texas.

2013 Before the Line. Vol. III, Caddo Indians: The Final Years. The START Group, Huntsville, Texas.

2013 The Caddo Nation begins to Reassemble, 1840-1851. Caddo Archeology Journal 23:141-155.

Tiller, J. and G. Gong

2012 July 1, 1835: What did the Caddo Believe they were Selling, and was the Price Paid Fair? Caddo Archeology Journal 22:115-142.

Torget, A. J.

2016 Seeds of Empire: Cotton, Slavery, and the Transformation of the Texas Borderlands, 1800-1850. University of North Carolina Press, Chapel Hill.

Tous, G. (translator)

1930 The Espinosa-Olivares-Aguirre Expedition of 1709. Preliminary Studies of the Texas Catholic Historical Society l(3):1-14.

1930 Ramon's Expedition: Espinosa's Diary of 1716. Preliminary Studies of the Texas Catholic Historical Society I(4):1-24.

Troike, R. C.

1964 The Caddo Word for 'Water'. International Journal of American Linguistics 30:96-98.

Varner, J. G. and J. J. Varner (editors and translators)

1951 The Florida of the Inca. University of Texas Press, Austin.

Vogel, R. C.

2003 Paul Bouet Laffitte: A Borderlands Life. East Texas Historical Journal XLI (1): 15-27.

Webb, M. L.

1965 Religious and Educational Efforts among Texas Indians in the 1850s. Southwestern Historical Quarterly 69:22-37.

Weber, D. J.

1992 The Spanish Frontier in North America. Yale University Press, New Haven.

2005 Barbaros: Spaniards and Their Savages in the Age of Enlightenment. Yale University Press, New Haven. 
Weddle, R. S.

1991 The French Thorn: Rival Explorers in the Spanish Sea, 1682-1762. Texas A\&M University Press, College Station.

1992 Cross and Crown: The Spanish Mission in Texas. In Hispanic Texas: A Historical Guide, edited by H. Simons and C. A. Hoyt, pp. 25-35. University of Texas Press, Austin.

1999 Wilderness Manhunt: The Spanish Search for La Salle. Texas A\&M University Press, College Station.

2001 The Wreck of the Belle, the Ruin of La Salle. Texas A\&M University Press, College Station.

2007 After the Massacre: The Violent Legacy of the San Saba Mission. Texas Tech University Press, Lubbock.

2012 Archival and Archaeological Research: Camino Real de los Tejas and Texas State Parks. Texas Parks and Wildlife Department, Austin.

Weddle, R. S. (editor)

1987 La Salle, the Mississippi, and the Gulf: Three Primary Documents. Texas A\&M University Press, College Station.

Weddle, R. S., D. E. Chipman, and C. A. Lipscomb

2016 The Misplacement of Mission San Francisco de los Tejas in Eastern Texas and Its Actual Location at San Pedro de los Nabedaches. Southwestern Historical Quarterly 120(1):74-84.

Wedel, M. M.

1971 J. B. Benard, Sieur De La Harpe: Visitor to the Wichitas in 1719. Great Plains Journal 10:37-70.

1972 Claude-Charles Dutisne: A Review of his 1719 Journeys, Part 1. Great Plains Journal 12(1):5-25.

1973 Claude-Charles Dutisne: A Review of his 1719 Journeys, Part II. Great Plains Journal 12(2):147-173.

1978 LaHarpe's 1719 Post on the Red River and Nearby Caddo Settlements. Bulletin No. 30. Texas Memorial Museum, Austin.

Weisman, D.

2011 Caddo Country: Unearthing Native American Heritage in East Texas. Texas Highways 58(11):50-58. 
West, E. H. (translator)

1905 De Leon's Expedition of 1689. Quarterly of the Texas State Historical Association 8:199-224.

Whayne, J. M., T. A. DeBlack, G. Sabo III, and M. S. Arnold

2002 Arkansas: A Narrative History. University of Arkansas Press, Fayetteville.

2013 Arkansas: A Narrative History. Second edition, University of Arkansas Press, Fayetteville.

Williams, J. W.

1942 Moscoso's Trail in Texas. Southwestern Historical Quarterly 46:138-157.

1979 Old Texas Trails. Eakin Press, Austin.

Williams, S.

1974 The Aboriginal Location of the Kadohadacho and Related Indian Tribes. In Caddoan Indians I, edited by D. A. Horr, pp. 281-330. Garland Publishing, Inc., New York.

Winfrey, D. H., and J. M. Day (editors)

1995 The Indian Papers of Texas and the Southwest 1825-1916. 5 Vols. Texas State Historical Association, Austin.

Woldert, A. E.

1935 The Location of the Tejas Indian Villages (San Pedro) and the Spanish Missions in Houston County. Southwestern Historical Quarterly 38(3):203212.

1942 The Expedition of Luis de Moscoso in Texas in 1542. Southwestern Historical Quarterly 46(2):158-166.

Wood, P. H.

1989 The Changing Population of the Colonial South: An Overview by Race and Region, 1685-1790. In Powhatan's Mantle: Indians in the Colonial Southeast, edited by P. H. Wood, G. A. Waselkov, and M. T. Harley, pp. 35-103. University of Nebraska Press, Lincoln.

Young, G. A. and M. P. Hoffman (editors)

1993 The Expedition of Hernando de Soto West of the Mississippi, 1541-1543: Proceedings of the DeSoto Symposia, 1988 and 1990. University of Arkansas Press, Fayetteville. 